\title{
Implementation of the CYP Index for the design of selective tryptophan-2,3-dioxygenase (TDO) inhibitors
}

Brendan T. Parr, ${ }^{*}+$ Richard Pastor, ${ }^{\dagger}$ Benjamin D. Sellers, ${ }^{\dagger}$ Zhonghua Pei, ${ }^{\dagger}$ Firoz A. Jaipuri, ${ }^{\ddagger}$ Georgette M. Castanedo, ${ }^{\dagger}$ Lewis Gazzard, ${ }^{\dagger}$ Sanjeev Kumar, ${ }^{\dagger}$ Xiaokai Li, ${ }^{\dagger}$ Wen Liu, ${ }^{\dagger}$ Rohan Mendonca, ${ }^{\dagger}$ Roheeth K. Pavana, ${ }^{\ddagger}$ Hima Potturi, ${ }^{\ddagger}$ Cheng Shao, ${ }^{\S}$ Venkata Velvadapu, ${ }^{\ddagger}$ Jesse P. Waldo, ${ }^{\ddagger}$ Guosheng Wu,,${ }^{\S}$ Po-wai Yuen, ${ }^{\S}$ Zuhui Zhang, ${ }^{\ddagger}$ Yamin Zhang, ${ }^{\S}$ Seth F. Harris, ${ }^{\dagger}$ Angela J. Oh, ${ }^{+}$Antonio DiPasquale, ${ }^{\dagger}$ Kevin DeMent, ${ }^{\dagger}$ Hank La, ${ }^{\dagger}$ Leanne Goon, ${ }^{+}$Amy Gustafson, ${ }^{\dagger}$ Erica C. VanderPorten, ${ }^{+}$Mario R. Mautino ${ }^{\dagger}$ and Yichin $\mathrm{Liu}^{+}$

$\dagger$ Genentech, South San Francisco, California 94080, United States

+ NewLink Genetics, Ames, Iowa 50010, United States

$\S$ Pharmaron, Beijing, People's Republic of China 100176

\section{TABLE OF CONTENTS}

General Information

Computational Methods

Synthetic Schemes

Characterization Data 


\section{General Information}

All solvents and commercial reagents were used as received unless otherwise stated. Where products were purified by chromatography on silica gel this was carried out using either a glass column manually packed with silica gel (Kieselgel 60, 220-440 mesh, 35-75 $\mu \mathrm{m}$ ) or an Isolute SPE Si II cartridge. 'Isolute SPE Si cartridge' refers to a pre-packed polypropylene column containing unbonded activated silica with irregular particles with average size of $50 \mu \mathrm{m}$ and nominal $60 \AA$ porosity. Where an Isolute ${ }^{\circledR}$ SCX2 cartridge was used, 'Isolute ${ }^{\circledR}$ SCX-2 cartridge' refers to a pre-packed polypropylene column containing a non-end-capped propylsulphonic acid functionalized silica strong cation exchange sorbent. ${ }^{1} \mathrm{H}$ NMR spectra were obtained at ambient temperature, unless otherwise indicated, in deuterated $\mathrm{CDCl}_{3}, \mathrm{DMSO}-$ $d_{6}$ or methanol- $d_{4}$ solvent solutions (reported in ppm) using trimethylsilane (TMS) or residual non-deuterated solvent peaks as the reference standard. When peak multiplicities are reported, the following abbreviates are used: app (apparent), s (singlet), d (doublet), t (triplet), q (quartet), $\mathrm{m}$ (multiplet), br (broad), dd (doublet of doublets), dt (doublet of triplets). Coupling constants, when determined, are reported in $\mathrm{Hz}$ (Hertz). LC-MS analysis was performed on a Shimadzu LCMS-202 instrument equipped with Waters Acquity BEH C18-reverse-phase column $(50 \mathrm{~mm}$ $\times 2.1 \mathrm{~mm} \times 1.7 \mu \mathrm{m}$ ), eluting with water $(+0.1 \%$ formic acid, $0.05 \%$ trifluoroacetic acid or $0.1 \%$ ammonium hydroxide)-acetonitrile. Compounds $2,{ }^{1} 7,{ }^{1} 8,{ }^{2} 9,{ }^{3} 11-18,{ }^{3} 20-24,{ }^{3} 26-31,{ }^{3} 38,{ }^{4} 45,{ }^{5}$ $\mathbf{5 2}{ }^{1}$ and $\mathbf{6 5}^{1}$ were prepared according to published procedures. 


\section{Computational Methods}

The ability of each tricyclic core (e.g. 1-6) to coordinate with a heme iron was estimated through a calculation of the partial charge of the iron-binding nitrogen using quantum mechanical calculations with Schrodinger's Jaguar ${ }^{6}$ version 8.7 at a B3LYP/6-31G** level of theory. Following a geometry optimization of each three-ring core, partial charges at the nitrogen atom were derived from the electrostatic potential. 


\section{Synthetic Schemes}<smiles>O=C(O)c1n[nH]c2ccccc12</smiles>

32<smiles>[C+]CCn1c2ccccc2c2cncn21</smiles>

37

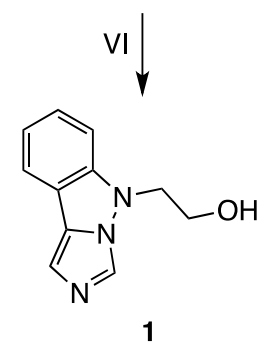

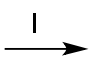
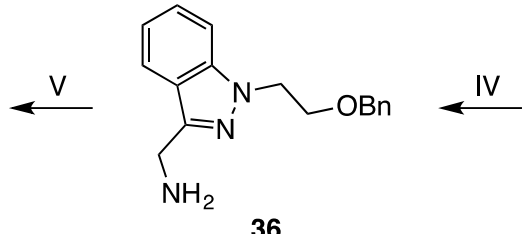

36

33
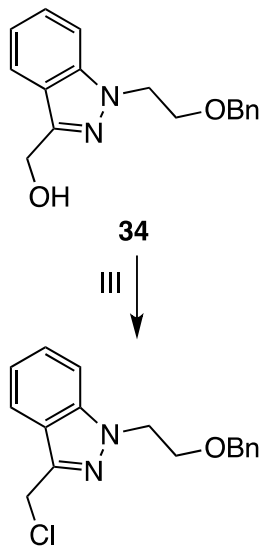

35

Scheme S1. Reagents and conditions: (I) lithium aluminum hydride, tetrahydrofuran, $25^{\circ} \mathrm{C}$; (II) ((2-bromoethoxy)methyl)benzene, potassium tert-butoxide, $N, N$-dimethylformamide, $25^{\circ} \mathrm{C}$; (III) thionyl chloride, toluene, $60{ }^{\circ} \mathrm{C}$; (IV) ammonium hydroxide, $N, N$-dimethylformamide, 1,4 dioxane, $50{ }^{\circ} \mathrm{C}$; (V) formic acid, acetic anhydride, $60{ }^{\circ} \mathrm{C}$ then phosphoryl chloride, toluene, 100 ${ }^{\circ} \mathrm{C}$; (VI) palladium-on-carbon, hydrogen (1 atm), acetic acid, methanol, $25^{\circ} \mathrm{C}$. 


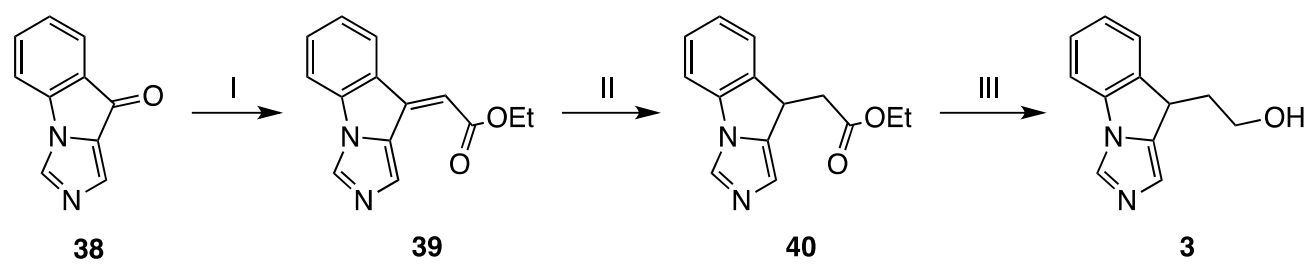

Scheme S2. Reagents and conditions: (I) ethyl 2-(diethoxyphosphoryl)acetate, sodium hydride, tetrahydrofuran, $0-25{ }^{\circ} \mathrm{C}$; (II) palladium-on-carbon, hydrogen $(10 \mathrm{~atm})$, ethyl acetate, $25^{\circ} \mathrm{C}$; (III) lithium aluminum hydride, tetrahydrofuran, $0^{\circ} \mathrm{C}$. 


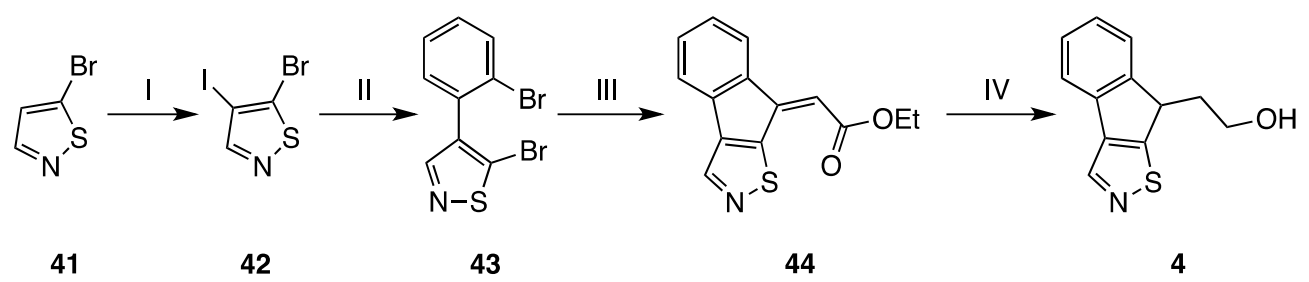

Scheme S3. Reagents and conditions: (I) $N$-iodosuccinimide, trifluoroacetic acid, $80{ }^{\circ} \mathrm{C}$; (II) (2bromophenyl)boronic acid, bis(triphenylphosphine)palladium(II) dichloride, sodium bicarbonate, 1,4-dioxane, water, $100^{\circ} \mathrm{C}$; (III) ethyl propenoate, palladium(II) acetate, tris( $o$-tolyl)phosphine, potassium acetate, $N, N$-dimethylformamide, $100{ }^{\circ} \mathrm{C}$; (IV) sodium borohydride, methanol, $25{ }^{\circ} \mathrm{C}$. 


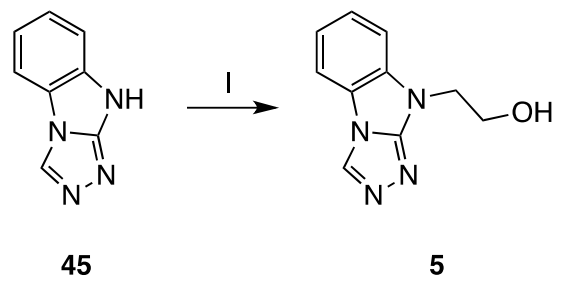

Scheme S4. Reagents and conditions: (I) 2-bromoethan-1-ol, potassium hydroxide, $N, N$ dimethylformamide, $25^{\circ} \mathrm{C}$. 
<smiles>Nc1ccccc1I</smiles>

46<smiles>CCOC(=O)/C=c1\c2ccccc2n2nncc12</smiles>

51

VI<smiles>OCCC1c2ccccc2-n2nncc21</smiles>

6<smiles>Nc1ccccc1I</smiles><smiles>C1CCCC1</smiles>

47

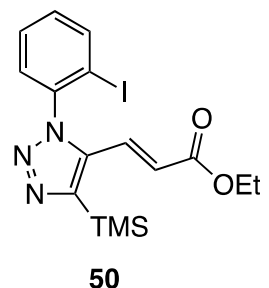

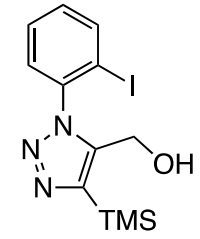

48

III

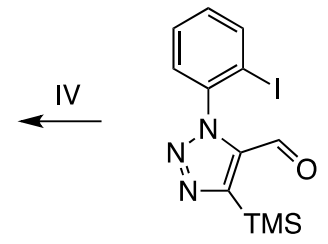

49

Scheme S5. Reagents and conditions: (I) sodium nitrate, sodium azide, hydrogen chloride, water, $0{ }^{\circ} \mathrm{C}$; (II) 3-(trimethylsilyl)prop-2-yn-1-ol, toluene, $110^{\circ} \mathrm{C}$; (III) Dess-Martin periodinane, dichloromethane, $25^{\circ} \mathrm{C}$; (IV) ethyl (triphenylphosphoranylidene)acetate, tetrahydrofuran, $25^{\circ} \mathrm{C}$; (V) palladium(II) acetate, tris ( $o$-tolyl)phosphine, potassium acetate, $N, N$-dimethylformamide, $100{ }^{\circ} \mathrm{C}$; (VI) sodium borohydride, methanol, $25^{\circ} \mathrm{C}$. 


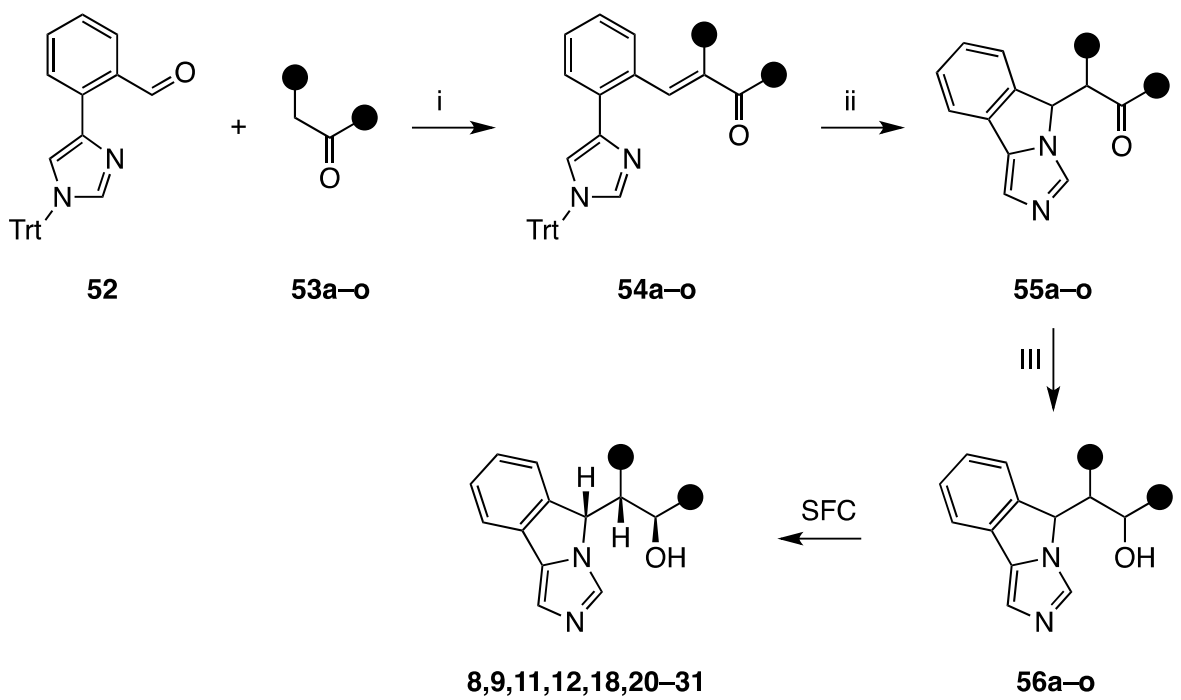

Scheme S6. Reagents and conditions: (I) See Table S1; (II) acetic acid, methanol, $70{ }^{\circ} \mathrm{C}$; (III) sodium borohydride, methanol, $25^{\circ} \mathrm{C}$. 
Table S1. Reaction conditions for Step I aldol condensation

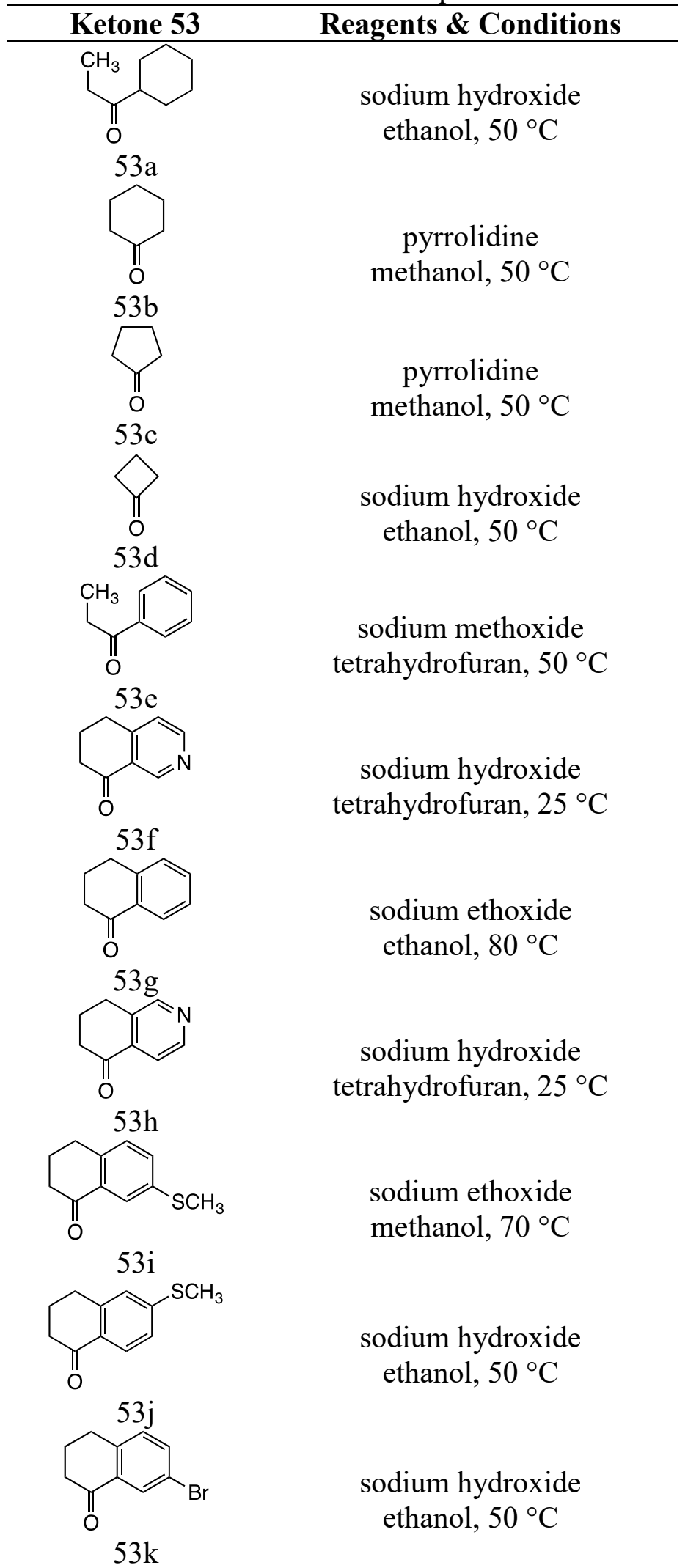


<smiles>N#Cc1ccc2c(c1)C(=O)CCC2</smiles>

531<smiles>O=C1CCCn2cnnc21</smiles>

$53 \mathrm{~m}$<smiles>O=C1CCCc2nonc21</smiles>

$53 n$<smiles>O=C1CCCn2nccc21</smiles>

530<smiles>Cn1ncc2c1CCCC2=O</smiles>

$53 p$ sodium ethoxide

methanol, $70{ }^{\circ} \mathrm{C}$

lithium hydroxide

tetrahydrofuran/water, $25^{\circ} \mathrm{C}$

pyrrolidine

methanol, $70{ }^{\circ} \mathrm{C}$

sodium hydroxide ethanol, $50{ }^{\circ} \mathrm{C}$

sodium hydroxide ethanol, $50^{\circ} \mathrm{C}$ 


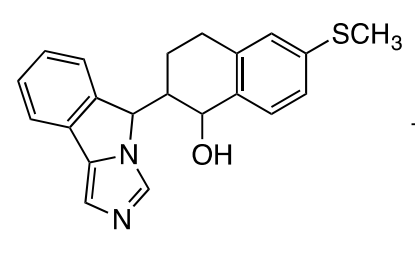

$56 i$

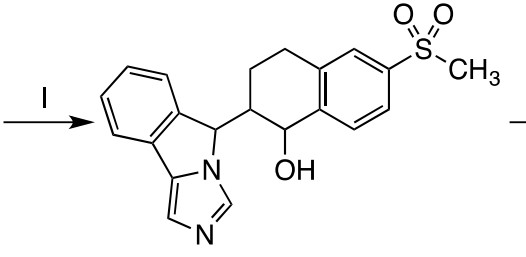

57

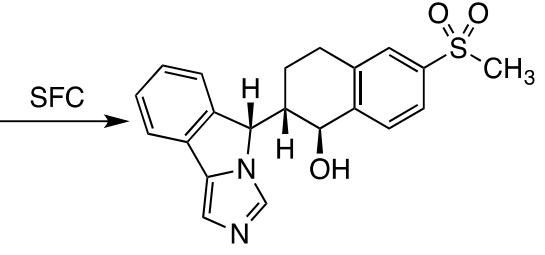

23

Scheme S7. Reagents and conditions: (I) hydrogen peroxide (30\% aqueous solution), acetic acid, $25{ }^{\circ} \mathrm{C}$. 


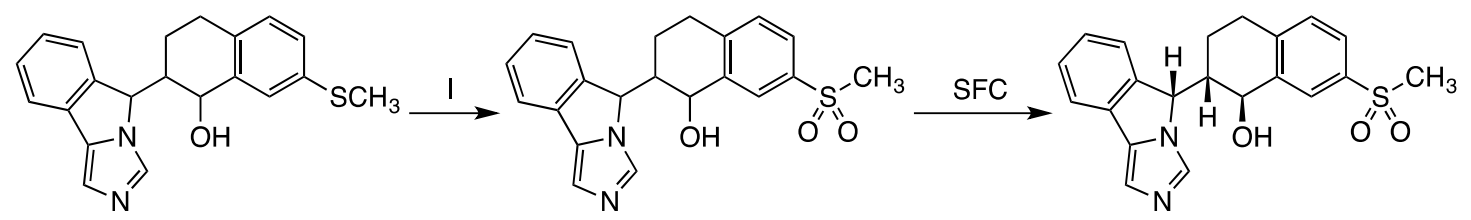

56j

58

24

Scheme S8. Reagents and conditions: (I) hydrogen peroxide (30\% aqueous solution), acetic acid, $25{ }^{\circ} \mathrm{C}$. 


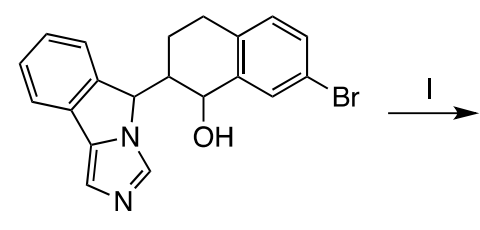

56k

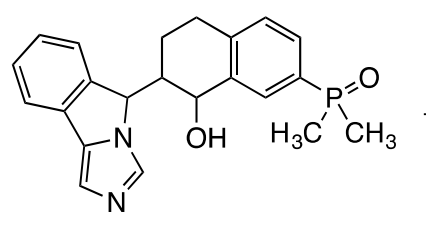

59

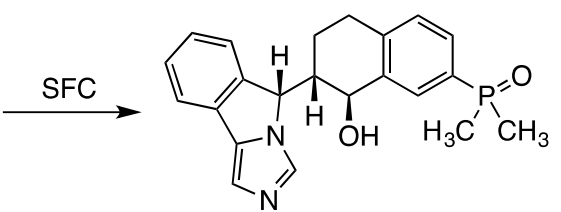

25

Scheme S9. Reagents and conditions: (I) dimethylphosphine oxide, palladium(II) acetate, 4,5bis(diphenylphosphino)-9,9-dimethylxanthene, potassium phosphate, $N, N$-dimethylformamide, $140{ }^{\circ} \mathrm{C}$. 


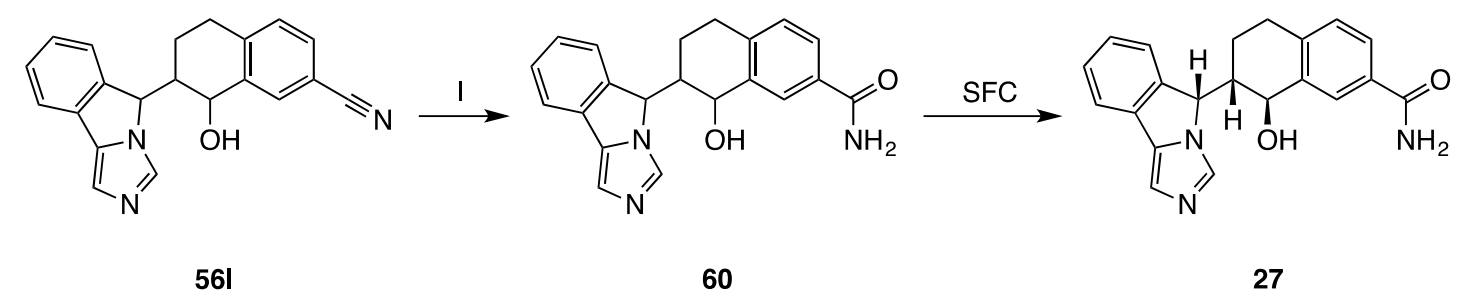

Scheme S10. Reagents and conditions: (I) sodium hydroxide, sodium peroxide (30\% aqueous solution), methanol, $25^{\circ} \mathrm{C}$. 


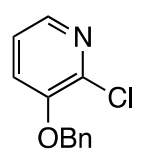

61

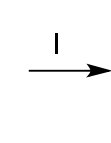

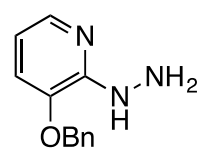

62<smiles>O=C1CCCn2cnnc21</smiles>

$53 n$

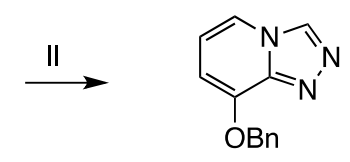

63

III

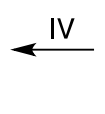

64

Scheme S11. Reagents and conditions: (I) hydrazine, potassium carbonate, isopropanol, $100{ }^{\circ} \mathrm{C}$; (II) triethyl orthoformate, $160{ }^{\circ} \mathrm{C}$; (III) palladium-on-carbon, hydrogen $(1 \mathrm{~atm})$, methanol, $25^{\circ} \mathrm{C}$; (IV) Dess-Martin periodinane, dichloromethane, $25{ }^{\circ} \mathrm{C}$. 


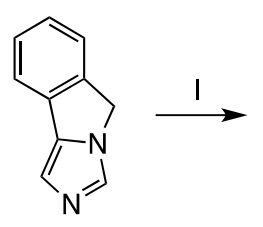

65

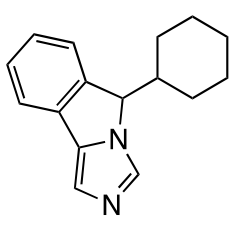

rac- 10

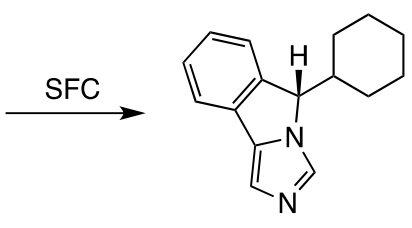

10

Scheme S12. Reagents and conditions: (I) $n$-butyllithium, bromocyclohexane, tetrahydrofuran, $78-25^{\circ} \mathrm{C}$. 


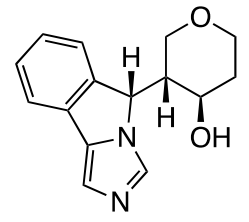

14 SFC $\uparrow$<smiles>c1ccc2c(c1)Cn1cncc1-2</smiles>

65<smiles>[X]C1CCC2OC2C1</smiles>

$66 a, b$

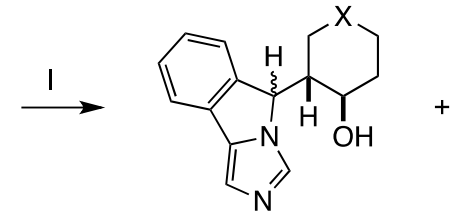

67a,b<smiles>OC1COCC[C@H]1[C@H]1c2ccccc2-c2cncn21</smiles>

13

$$
\text { SFC } \uparrow
$$

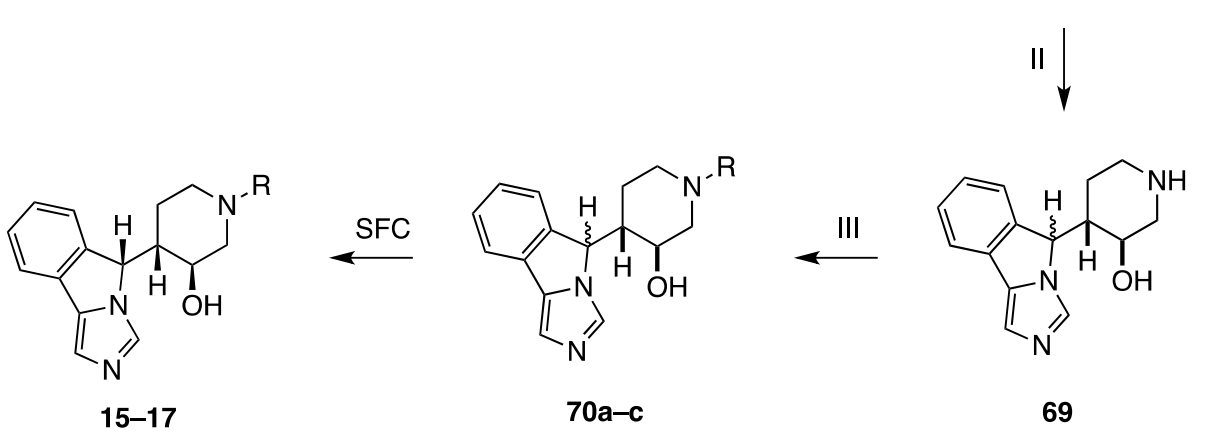

Scheme S13. Reagents and conditions: (I) 39a, $\mathrm{X}=\mathrm{O}, \mathbf{3 9} \mathbf{b}, \mathrm{X}=N$-Boc, $n$-butyllithium, tetrahydrofuran, $-78-25^{\circ} \mathrm{C}$; (II) $\mathbf{6 8 b}$, trifluoroacetic acid, dichloromethane, $25^{\circ} \mathrm{C}$; (III) See Table S2. 
Table S2. Reaction conditions for Step III $N$-substitution

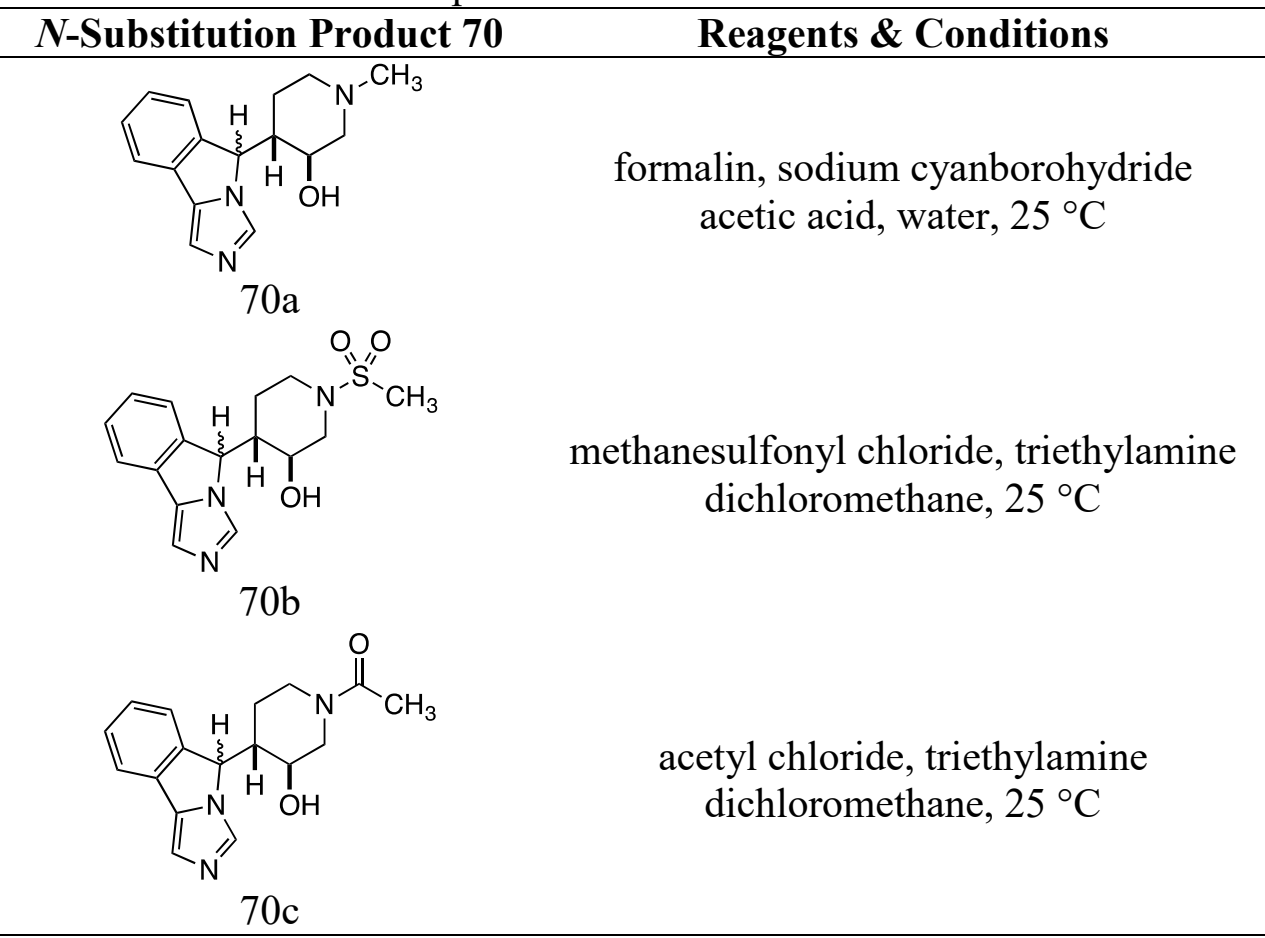


<smiles>CCOC(=O)C(C)(C)C(O)C(O)c1ccccc1-c1cn(CC)cn1</smiles>

72

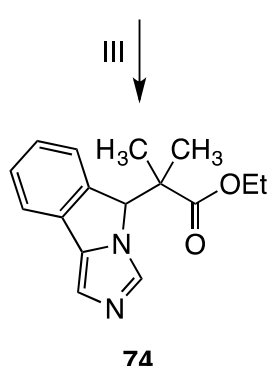

76
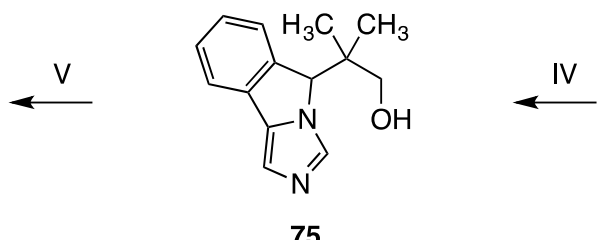

74

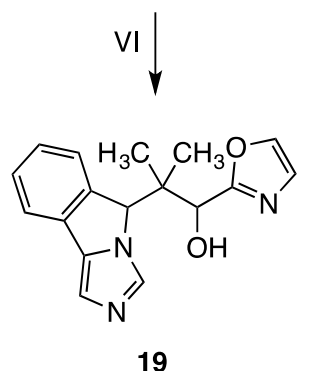

Scheme S14. Reagents and conditions: (I) $N, N$-diisopropylamine, $n$-butyllithium, tetrahydrofuran, $-40{ }^{\circ} \mathrm{C}$; (II) acetic acid, methanol, $70{ }^{\circ} \mathrm{C}$; (III) cyanomethylene trimethyphosphorane, tetrahydrofuran, $25^{\circ} \mathrm{C}$; (IV) diisobutylaluminum hydride, toluene, 0-25 ${ }^{\circ} \mathrm{C}$; (V) Dess-Martin periodinane, sodium bicarbonate, dichloromethane, $25^{\circ} \mathrm{C}$; (VI) oxazole, $n$ butyllithium, tetrahydrofuran, $-78-25^{\circ} \mathrm{C}$. 


\section{Characterization Data}

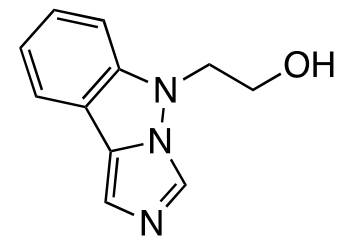

2-(5H-imidazo[1,5-b]indazol-5-yl)ethan-1-ol (1).<smiles>OCc1n[nH]c2ccccc12</smiles>

(1H-indazol-3-yl)methanol (33): To a solution of lithium aluminum hydride $(4.7 \mathrm{~g}, 120 \mathrm{mmol})$ in tetrahydrofuran $(500 \mathrm{~mL})$ was added $1 H$-indazole-3-carboxylic acid $(32,10 \mathrm{~g}, 62 \mathrm{mmol})$. The resulting solution was stirred for $5 \mathrm{~h}$ at $0{ }^{\circ} \mathrm{C}$. The reaction was then quenched with water and $15 \%$ sodium hydroxide. The solids were filtered out. The filtrate was concentrated under vacuum. Purification by silica gel flash chromatography eluting with $40 \%$ dichloromethaneethyl acetate afforded the title compound $(2.6 \mathrm{~g}, 28 \%)$ as a light yellow solid. LCMS-ESI (m/z): $[\mathrm{M}+\mathrm{H}]^{+}$calcd for $\mathrm{C}_{8} \mathrm{H}_{9} \mathrm{~N}_{2} \mathrm{O}, 149.2$; found 149.3.<smiles>OCc1nn(CCOc2ccccc2)c2ccccc12</smiles>

(1-(2-(benzyloxy)ethyl)-1 $H$-indazol-3-yl)methanol (34): To a solution of $1 H$-indazol-3ylmethanol $(33,2.6 \mathrm{~g}, 17.6 \mathrm{mmol})$ in $N, N$-dimethylformamide $(120 \mathrm{~mL})$ was added potassium tert-butoxide (3.94 g, $35 \mathrm{mmol}$ ) and ((2-bromoethoxy)methyl)benzene (5.67 g, $26 \mathrm{mmol})$. The resulting solution was stirred for $2 \mathrm{~h}$ at ambient temperature. The resulting solution was diluted with water and extracted with ethyl acetate. The organic layers were combined and concentrated under vacuum. Purification by silica gel flash chromatography eluting with $50 \%$ ethyl acetatepetroleum ether afforded the title compound $(3.5 \mathrm{~g}, 71 \%)$ as a yellow oil. LCMS-ESI (m/z): $[\mathrm{M}+\mathrm{H}]^{+}$calcd for $\mathrm{C}_{17} \mathrm{H}_{19} \mathrm{~N}_{2} \mathrm{O}_{2}, 283.3$; found 283.1.<smiles>ClCc1nn(CCOc2ccccc2)c2ccccc12</smiles>

1-(2-(benzyloxy)ethyl)-3-(chloromethyl)-1H-indazole (35): To a solution of (1-(2(benzyloxy)ethyl)-1H-indazol-3-yl)methanol (34, $2.5 \mathrm{~g}, 8.9 \mathrm{mmol})$ in toluene $(20 \mathrm{~mL})$ was added thionyl chloride $(10 \mathrm{~mL}, 138 \mathrm{mmol})$. The resulting solution was stirred for $1.5 \mathrm{~h}$ at $65^{\circ} \mathrm{C}$ in an oil bath. The resulting mixture was concentrated under vacuum to afford the title compound (2.5 g, crude) as a yellow oil. LCMS-ESI (m/z): $[\mathrm{M}+\mathrm{H}]^{+}$calcd for $\mathrm{C}_{17} \mathrm{H}_{18}{ }^{35} \mathrm{ClN}_{2} \mathrm{O}, 301.8$; found 301.2. 


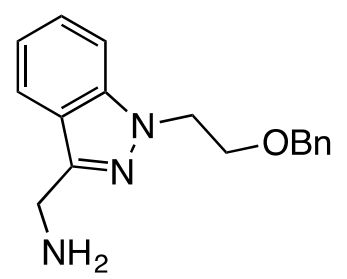

(1-(2-(benzyloxy)ethyl)-1H-indazol-3-yl)methanamine (36): To ammonia $(90 \mathrm{~mL})$ was added a solution of 1-(2-(benzyloxy)ethyl)-3-(chloromethyl)-1H-indazole (35, $2.5 \mathrm{~g}, 8.3 \mathrm{mmol})$ in 1,4dioxane $(10 \mathrm{~mL})$ and $N, N$-dimethylformamide $(5 \mathrm{~mL})$. The resulting solution was stirred for $2 \mathrm{~h}$ at $50{ }^{\circ} \mathrm{C}$ in an oil bath. The reaction mixture was concentrated under vacuum. Purification by silica gel flash chromatography eluting with $0.1 \%$ ammonia- $10 \%$ dichloromethane-methanol afforded the title compound $(1.3 \mathrm{~g}, 56 \%)$ as a yellow oil. LCMS-ESI $(\mathrm{m} / \mathrm{z}):[\mathrm{M}+\mathrm{H}]^{+}$calcd for $\mathrm{C}_{17} \mathrm{H}_{20} \mathrm{~N}_{3} \mathrm{O}$, 282.4; found 282.2.<smiles>c1ccc(OCCn2c3ccccc3c3cncn32)cc1</smiles>

5-(2-(benzyloxy)ethyl)-5H-imidazo[1,5-b]indazole (37): A mixture of (1-(2-(benzyloxy)ethyl)$1 \mathrm{H}$-indazol-3-yl)methanamine $(\mathbf{3 6}, 500 \mathrm{mg}, 1.8 \mathrm{mmol})$ in acetic anhydride $(10 \mathrm{~mL})$ and formic acid $(5 \mathrm{~mL})$ was stirred for $2 \mathrm{~h}$ at $60^{\circ} \mathrm{C}$ in an oil bath. The mixture was concentrated under vacuum, and resuspended in toluene $(10 \mathrm{~mL})$ and phosphorus oxychloride $(3 \mathrm{~mL})$. The resulting solution was stirred for $1 \mathrm{~h}$ at $100{ }^{\circ} \mathrm{C}$ in an oil bath. The reaction mixture was concentrated under vacuum. Purification by preparative HPLC afforded the title compound ( $85 \mathrm{mg}, 16 \%$ ) as a yellow oil. LCMS-ESI (m/z): [M+H] ${ }^{+}$calcd for $\mathrm{C}_{18} \mathrm{H}_{18} \mathrm{~N}_{3} \mathrm{O}$, 292.4; found 292.2.<smiles>OCCn1ncc2ccccc21</smiles>

2-(5H-imidazo[1,5-b]indazol-5-yl)ethan-1-ol (1): 5-(2-(benzyloxy)ethyl)-5H-imidazo[1,5b]indazole $(37,620 \mathrm{mg}, 2.1 \mathrm{mmol})$, acetic acid (25 mg, $0.42 \mathrm{mmol})$ and 10\% $\mathrm{Pd} / \mathrm{C} \mathrm{(45} \mathrm{mg)} \mathrm{were}$ combined in methanol $(25 \mathrm{~mL})$ under an atmosphere of hydrogen and stirred for $2 \mathrm{~h}$ at ambient temperature. The solids were removed by filtration. The filtrate was concentrated under vacuum. Purification by preparative HPLC afforded the title compound $(24 \mathrm{mg}, 5 \%)$ as a pale yellow solid. LCMS-ESI (m/z): $[\mathrm{M}+\mathrm{H}]^{+}$calcd for $\mathrm{C}_{11} \mathrm{H}_{12} \mathrm{~N}_{3} \mathrm{O}, 202.2$; found 202.1. ${ }^{1} \mathrm{H}$ NMR $(400 \mathrm{MHz}$, DMSO- $\left.d_{6}\right) \delta 8.18(\mathrm{~s}, 1 \mathrm{H}), 7.74(\mathrm{~d}, J=7.7 \mathrm{~Hz}, 1 \mathrm{H}), 7.43(\mathrm{~d}, J=8.2 \mathrm{~Hz}, 1 \mathrm{H}), 7.41-7.32(\mathrm{~m}, 1 \mathrm{H})$, $7.22-7.13(\mathrm{~m}, 2 \mathrm{H}), 4.96(\mathrm{t}, J=5.1 \mathrm{~Hz}, 1 \mathrm{H}), 4.21(\mathrm{t}, J=5.4 \mathrm{~Hz}, 2 \mathrm{H}), 3.79-3.62(\mathrm{~m}, 2 \mathrm{H})$.

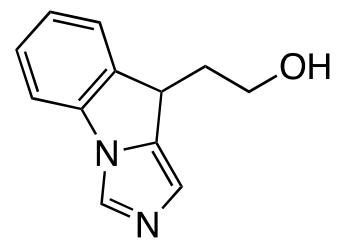

2-(9H-imidazo[1,5-a]indol-9-yl)ethan-1-ol (3). 


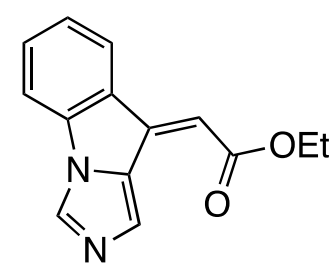

ethyl (Z)-2-(9H-imidazo[1,5-a]indol-9-ylidene)acetate (39): To a solution of ethyl 2(diethoxyphosphoryl)acetate $(263 \mathrm{mg}, 1.2 \mathrm{mmol})$ in tetrahydrofuran $(2 \mathrm{~mL})$ was added sodium hydride $(30 \mathrm{mg}, 1.2 \mathrm{mmol})$ at $0{ }^{\circ} \mathrm{C}$. After $5 \mathrm{~min}$, a tetrahydrofuran $(1 \mathrm{~mL})$ solution of $9 \mathrm{H}$ Imidazo[1,5-a]indol-9-one $(\mathbf{3 8}, 100 \mathrm{mg}, 0.59 \mathrm{mmol})$ was added to the reaction vessel. The reaction was allowed to warm to ambient temperature for $1 \mathrm{~h}$. The crude mixture was concentrated under vacuum. The residue was partitioned between ethyl acetate and water. The organic layer was washed with water and dried over anhydrous sodium sulfate. The solvent was removed under vacuum. Purification by silica gel flash chromatography eluting with 1-10\% methanol-dichloromethane afforded the title compound $(120 \mathrm{mg}, 85 \%)$ as a yellow solid. LCMS-ESI (m/z): $[\mathrm{M}+\mathrm{H}]^{+}$calcd for $\mathrm{C}_{14} \mathrm{H}_{13} \mathrm{~N}_{2} \mathrm{O}_{2}, 241.3$; found 241.0.<smiles>CCOC(=O)CC1c2ccccc2-n2cncc21</smiles>

ethyl 2-(9H-imidazo[1,5-a]indol-9-yl)acetate (40): A suspension of ethyl $(Z)-2-(9 H$-imidazo[1,5a] indol-9-ylidene)acetate $(\mathbf{3 9}, 200 \mathrm{mg}, 0.83 \mathrm{mmol})$ and palladium-on-carbon $(100 \mathrm{mg})$ in ethyl acetate $(4 \mathrm{~mL})$ was stirred under hydrogen $(10 \mathrm{~atm})$ for $2 \mathrm{~h}$ at room temperature. The reaction mixture was filtered. The solvent was removed under vacuum to afford the title compound $(175 \mathrm{mg}, 85 \%)$ as a pale yellow solid. LCMS-ESI (m/z): $[\mathrm{M}+\mathrm{H}]^{+}$calcd for $\mathrm{C}_{14} \mathrm{H}_{15} \mathrm{~N}_{2} \mathrm{O}_{2}, 243.3$; found 243.1 .

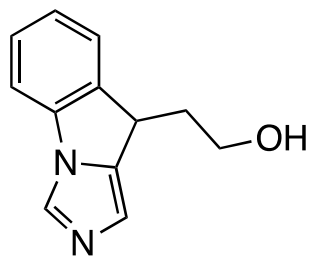

2-(9H-imidazo[1,5-a]indol-9-yl)ethan-1-ol (3): To a solution of ethyl 2-(9H-imidazo[1,5a] indol-9-yl)acetate $(\mathbf{4 0}, 120 \mathrm{mg}, 0.50 \mathrm{mmol})$ in tetrahydrofuran $(5 \mathrm{~mL})$ was added lithium aluminum hydride $(56 \mathrm{mg}, 1.5 \mathrm{mmol})$ at $0{ }^{\circ} \mathrm{C}$. The resulting suspension was allowed to warm to ambient temperature for $2 \mathrm{~h}$. The reaction was quenched with water and extracted with ethyl acetate. The organic layer was washed with water and dried over anhydrous sodium sulfate. The solvent was removed under vacuum. Purification by silica gel flash chromatography eluting with $1-10 \%$ methanol-dichloromethane afforded the title compound $(6 \mathrm{mg}, 4 \%)$ as a pale yellow solid. LCMS-ESI (m/z): $[\mathrm{M}+\mathrm{H}]^{+}$calcd for $\mathrm{C}_{12} \mathrm{H}_{13} \mathrm{~N}_{2} \mathrm{O}$, 201.3; found 201.1. ${ }^{1} \mathrm{H}$ NMR (400 MHz, DMSO-d $d_{6} \delta 8.22(\mathrm{~s}, 1 \mathrm{H}), 7.68(\mathrm{~d}, J=7.8 \mathrm{~Hz}, 1 \mathrm{H}), 7.54(\mathrm{dq}, J=7.5,1.0 \mathrm{~Hz}, 1 \mathrm{H}), 7.39(\mathrm{tt}, J=$ $7.8,1.0 \mathrm{~Hz}, 1 \mathrm{H}), 7.24(\mathrm{td}, J=7.6,1.1 \mathrm{~Hz}, 1 \mathrm{H}), 6.91(\mathrm{~d}, J=1.4 \mathrm{~Hz}, 1 \mathrm{H}), 4.62(\mathrm{t}, J=5.1 \mathrm{~Hz}, 1 \mathrm{H})$, $4.19(\mathrm{dd}, J=9.8,5.1 \mathrm{~Hz}, 1 \mathrm{H}), 3.66(\mathrm{dt}, J=7.3,5.7 \mathrm{~Hz}, 3 \mathrm{H}), 2.17(\mathrm{dtd}, J=12.7,7.4,5.1 \mathrm{~Hz}, 1 \mathrm{H})$, 1.60 (ddt, $J=13.3,9.7,5.8 \mathrm{~Hz}, 1 \mathrm{H})$. 


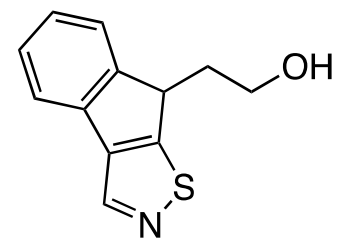

2-(8H-indeno[1,2-d] isothiazol-8-yl)ethan-1-ol (4).<smiles>Brc1cnsc1I</smiles>

5-bromo-4-iodo-1,2-thiazole (42): To a solution of 5-bromo-1,2-thiazole (41, $500 \mathrm{mg}, 3.0 \mathrm{mmol})$ in trifluoroacetic acid $(50 \mathrm{~mL})$ was added $N$-iodosuccinimide $(1.6 \mathrm{~g}, 7.1 \mathrm{mmol})$. The resulting solution was stirred for $12 \mathrm{~h}$ at $80^{\circ} \mathrm{C}$. The reaction was quenched with water and extracted with ethyl acetate. The solvent was removed under vacuum. Purification by silica gel flash chromatography eluting with $5 \%$ ethyl acetate-petroleum ether afforded the title compound (600 $\mathrm{mg}, 68 \%)$ as a yellow solid. LCMS-ESI $(\mathrm{m} / \mathrm{z})$ : $[\mathrm{M}+\mathrm{H}]^{+}$calcd for $\mathrm{C}_{3} \mathrm{H}_{2}{ }^{79} \mathrm{BrINS}, 289.9$; found 289.8 .<smiles>Brc1ccccc1-c1cnsc1Br</smiles>

5-bromo-4-(2-bromophenyl)-1,2-thiazole (43): To a solution of 5-bromo-4-iodo-1,2-thiazole (42, $500 \mathrm{mg}, 1.7 \mathrm{mmol})$ in dioxane $(10 \mathrm{~mL})$ and water $(2 \mathrm{~mL})$ was added (2-bromophenyl)boronic acid (345 mg, $1.7 \mathrm{mmol}$ ), bis(triphenylphosphine)palladium(II) dichloride (120 mg, $0.17 \mathrm{mmol}$ ) and sodium bicarbonate $(540 \mathrm{mg}, 6.4 \mathrm{mmol}$ ). The resulting solution was stirred for $15 \mathrm{~min}$ at 120 ${ }^{\circ} \mathrm{C}$. The reaction mixture was concentrated under vacuum. Purification by silica gel flash chromatography eluting with $10 \%$ ethyl acetate-petroleum ether afforded the title compound (300 mg, 55\%) as yellow oil. LCMS-ESI (m/z): $[\mathrm{M}+\mathrm{H}]^{+}$calcd for $\mathrm{C}_{9} \mathrm{H}_{6}{ }^{79} \mathrm{Br}_{2} \mathrm{NS}, 317.9$; found 318.1 .<smiles>CCOC(=O)C=C1c2ccccc2-c2cnsc21</smiles>

ethyl (Z)-2-(8H-indeno[1,2- $d$ ] isothiazol-8-ylidene)acetate (44): To a solution of 5-bromo-4-(2bromophenyl)-1,2-thiazole $(\mathbf{4 3}, 500 \mathrm{mg}, 1.6 \mathrm{mmol})$ in $N, N$-dimethylformamide $(10 \mathrm{~mL})$ was added ethyl prop-2-enoate $(1.0 \mathrm{~g}, 10 \mathrm{mmol})$, palladium(II) acetate $(20 \mathrm{mg}, 0.09 \mathrm{mmol})$, potassium acetate $(387 \mathrm{mg}, 15 \mathrm{mmol})$ and tris $(o$-tolyl)phosphine $(20 \mathrm{mg}, 0.07 \mathrm{mmol})$. The resulting solution was stirred for $12 \mathrm{~h}$ at $100^{\circ} \mathrm{C}$. The reaction was quenched with water and extracted with ethyl acetate. The solvent was removed under vacuum. Purification by silica gel flash chromatography eluting with $10 \%$ ethyl acetate-petroleum ether afforded the title compound (150 mg, $40 \%$ ) as yellow oil. LCMS-ESI (m/z): $[\mathrm{M}+\mathrm{H}]^{+}$calcd for $\mathrm{C}_{14} \mathrm{H}_{12} \mathrm{NO}_{2} \mathrm{~S}$, 258.1; found 258.1 . 


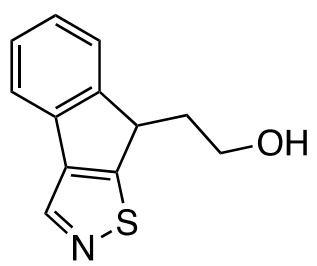

2-(8H-indeno[1,2- $d$ ] isothiazol-8-yl)ethan-1-ol (4): To a solution of ethyl (Z)-2-(8H-indeno[1,2$d$ ] isothiazol-8-ylidene)acetate $(\mathbf{4 4}, 300 \mathrm{mg}, 1.2 \mathrm{mmol})$ in methanol $(20 \mathrm{~mL})$ was added sodium borohydride( $1.2 \mathrm{~g}, 32 \mathrm{mmol})$. The resulting solution was stirred for $3 \mathrm{~h}$ at ambient temperature. The reaction was then quenched with water and extracted with ethyl acetate. The organic layers were combined and concentrated under vacuum. Purification by silica gel flash chromatography eluting with 50\% ethyl acetate-petroleum ether afforded the title compound $(25 \mathrm{mg}, 10 \%)$ as yellow oil. LCMS-ESI (m/z): $[\mathrm{M}+\mathrm{H}]^{+}$calcd for $\mathrm{C}_{12} \mathrm{H}_{12} \mathrm{NOS}, 218.1$; found 218.1. ${ }^{1} \mathrm{H}$ NMR (300 MHz, DMSO-d $\left.d_{6}\right) \delta 8.87(\mathrm{~s}, 1 \mathrm{H}), 7.73(\mathrm{~d}, J=7.4 \mathrm{~Hz}, 1 \mathrm{H}), 7.57(\mathrm{~d}, J=7.5 \mathrm{~Hz}, 1 \mathrm{H}), 7.36(\mathrm{t}, J=$ $7.4 \mathrm{~Hz}, 1 \mathrm{H}), 7.31-7.24(\mathrm{~m}, 1 \mathrm{H}), 4.99$ (t, $J=4.8 \mathrm{~Hz}, 1 \mathrm{H}), 4.25(\mathrm{dd}, J=10.5,4.2 \mathrm{~Hz}, 1 \mathrm{H}), 3.81-$ $3.68(\mathrm{~m}, 2 \mathrm{H}), 2.44-2.27(\mathrm{~m}, 1 \mathrm{H}), 1.63-1.43(\mathrm{~m}, 1 \mathrm{H})$.

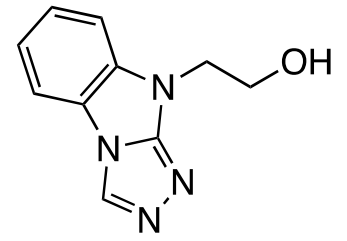

2-(9H-benzo[4,5]imidazo[2,1-c][1,2,4]triazol-9-yl)ethan-1-ol (5). To a solution of $9 H$ benzo[4,5]imidazo[2,1-c][1,2,4] triazole $(45,54 \mathrm{mg}, 0.34 \mathrm{mmol})$ in $N, N$-dimethylformamide (1 $\mathrm{mL}$ ) was added cesium carbonate $(156 \mathrm{mg}, 0.48 \mathrm{mmol})$ and 2-bromoethanol $(0.060 \mathrm{~mL}, 0.80$ $\mathrm{mmol})$. The resulting suspension was stirred for $4 \mathrm{~d}$ at ambient temperature. The mixture was dilute with ethyl acetate and filtered. The solvent was removed under vacuum. Purification by reverse phase HPLC on $\mathrm{C} 18$ with water $(0.1 \%$ ammonium hydroxide)-acetonitrile afforded the title compound $(2 \mathrm{mg}, 3 \%)$ as a tan solid. LCMS-ESI $(\mathrm{m} / \mathrm{z}):[\mathrm{M}+\mathrm{H}]^{+}$calcd for $\mathrm{C}_{10} \mathrm{H}_{11} \mathrm{~N}_{4} \mathrm{O}$, 203.1; found 203.1. ${ }^{1} \mathrm{H}$ NMR (400 MHz, DMSO- $\left.d_{6}\right) \delta 8.99(\mathrm{~s}, 1 \mathrm{H}), 7.87(\mathrm{~d}, J=7.9 \mathrm{~Hz}, 1 \mathrm{H})$, $7.57(\mathrm{~d}, J=8.2 \mathrm{~Hz}, 1 \mathrm{H}), 7.39(\mathrm{ddd}, J=8.3,7.4,1.2 \mathrm{~Hz}, 1 \mathrm{H}), 7.23(\operatorname{app} t \mathrm{~d}, J=7.8,1.1 \mathrm{~Hz}, 1 \mathrm{H})$, $4.85(\mathrm{t}, J=5.6 \mathrm{~Hz}, 1 \mathrm{H}), 4.22(\mathrm{t}, J=5.5 \mathrm{~Hz}, 2 \mathrm{H}), 3.87(\operatorname{app~q}, J=5.5 \mathrm{~Hz}, 2 \mathrm{H})$.

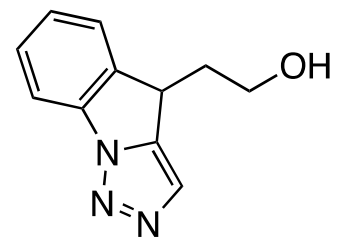

2-(4H-[1,2,3]triazolo[1,5-a]indol-4-yl)ethan-1-ol (6).<smiles></smiles>

1-azido-2-iodobenzene (47): To a solution of 2-iodoaniline (46, $1.0 \mathrm{~g}, 4.6 \mathrm{mmol})$ in aqueous hydrogen chloride $(6 \mathrm{~N})$ was added a solution of sodium nitrite $(380 \mathrm{mg}, 5.5 \mathrm{mmol})$ in water $(5$ $\mathrm{mL})$. The resulting solution was stirred for $40 \mathrm{~min}$ at $0{ }^{\circ} \mathrm{C}$. Then a solution of sodium azide $(590$ $\mathrm{mg}, 9.1 \mathrm{mmol})$ in water $(5 \mathrm{~mL})$ was added. The resulting solution was stirred for $1.5 \mathrm{~h}$ at $0{ }^{\circ} \mathrm{C}$. 
The aqueous solution was extracted with ethyl acetate and the organic layers were combined. The organic layer was concentrated under vacuum to afford the title compound (569 $\mathrm{mg}, 51 \%)$ as a brown oil. LCMS-ESI $(\mathrm{m} / \mathrm{z})$ : $[\mathrm{M}+\mathrm{H}]^{+}$calcd for $\mathrm{C}_{6} \mathrm{H}_{5} \mathrm{IN}_{3}, 246.0$; found 246.1. ${ }^{1} \mathrm{H}$ NMR (300 MHz, DMSO- $\left.d_{6}\right) \delta 7.85-7.82(\mathrm{~m}, 1 \mathrm{H}), 7.57-7.46(\mathrm{~m}, 1 \mathrm{H}), 7.45-7.33(\mathrm{~m}, 1 \mathrm{H}), 6.98-6.95$ $(\mathrm{m}, 1 \mathrm{H})$.<smiles>O=S(=O)(O)c1nnn(-c2ccccc2I)c1CO</smiles>

(1-(2-iodophenyl)-4-(trimethylsilyl)-1H-1,2,3-triazol-5-yl)methanol (48): To a solution of 1azido-2-iodobenzene $(\mathbf{4 7}, 5.0 \mathrm{~g}, 20 \mathrm{mmol})$ in toluene $(150 \mathrm{~mL})$ was added 3-(trimethylsilyl)prop2-yn-1-ol $(5.0 \mathrm{~g}, 39 \mathrm{mmol})$. The resulting solution was stirred for $24 \mathrm{~h}$ at $120{ }^{\circ} \mathrm{C}$ in an oil bath. The reaction mixture was concentrated under vacuum. Purification by silica gel flashed column eluting with 50\% ethyl acetate-petroleum ether afforded the title compound $(3.0 \mathrm{~g}, 39 \%)$ as a pale yellow solid. LCMS-ESI (m/z): $[\mathrm{M}+\mathrm{H}]^{+}$calcd for $\mathrm{C}_{12} \mathrm{H}_{17} \mathrm{IN}_{3} \mathrm{OSi}$, 374.0; found 374.0.<smiles>CS(=O)(=O)c1nnn(-c2ccccc2I)c1C=O</smiles>

1-(2-iodophenyl)-4-(trimethylsilyl)-1H-1,2,3-triazole-5-carbaldehyde (49): To a solution of (1(2-iodophenyl)-4-(trimethylsilyl)-1H-1,2,3-triazol-5-yl)methanol (48, $2.0 \mathrm{~g}, 5.4 \mathrm{mmol})$ in dichloromethane $(100 \mathrm{~mL})$ was added (1,1,1-triacetoxy)-1,1-dihydro-1,2-benziodoxol-3(1H)-one $(4.5 \mathrm{~g}, 11 \mathrm{mmol})$. The resulting solution was stirred for $3 \mathrm{~h}$ at ambient temperature. The resulting solution was diluted with ethyl acetate. The solids were removed by filtration. The resulting mixture was concentrated under vacuum to afford the title compound $(2.5 \mathrm{~g}$, crude) as a pale red solid. LCMS-ESI (m/z): $[\mathrm{M}+\mathrm{H}]^{+}$calcd for $\mathrm{C}_{12} \mathrm{H}_{15} \mathrm{IN}_{3} \mathrm{OSi}$, 372.0; found 372.1.

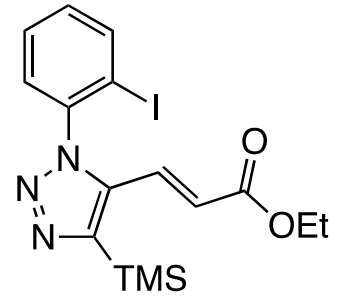

ethyl (2E)-3-[1-(2-iodophenyl)-4-(trimethylsilyl)-1H-1,2,3-triazol-5-yl]prop-2-enoate (50): To a solution of 1-(2-iodophenyl)-4-(trimethylsilyl)-1 $H$-1,2,3-triazole-5-carbaldehyde (49, $2.5 \mathrm{~g}, 6.7$ $\mathrm{mmol})$ in tetrahydrofuran $(150 \mathrm{~mL}$ ) was added ethyl 2-(triphenylphosphoranylidene)acetate (2.3 $\mathrm{g}, 6.6 \mathrm{mmol})$. The resulting solution was stirred for $3 \mathrm{~h}$ at ambient. The solids were removed by filtration. The filtrate was concentrated under vacuum. Purification by silica gel flash chromatography eluting with $20 \%$ ethyl acetate-petroleum ether afforded the title compound (1.4 g, 47\%) as a pale yellow solid. LCMS-ESI (m/z): $[\mathrm{M}+\mathrm{H}]^{+}$calcd for $\mathrm{C}_{16} \mathrm{H}_{21} \mathrm{IN}_{3} \mathrm{O}_{2} \mathrm{Si}$, 442.0; found 442.1 . 


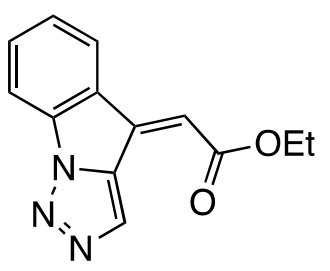

ethyl (Z)-2-(4H-[1,2,3]triazolo[1,5- $a$ ]indol-4-ylidene)acetate (51): To a solution of ethyl (2E)-3[1-(2-iodophenyl)-4-(trimethylsilyl)-1H-1,2,3-triazol-5-yl]prop-2-enoate (50, $300 \mathrm{mg}, 0.68$ $\mathrm{mmol})$ in $N, N$-dimethylformamide $(15 \mathrm{~mL})$ was added palladium(II) acetate $(30 \mathrm{mg}, 0.13 \mathrm{mmol})$, tri(2-methylphenyl)phosphine $(50 \mathrm{mg}, 0.16 \mathrm{mmol})$ and potassium acetate $(200 \mathrm{mg}, 2.0 \mathrm{mmol})$. The resulting solution was stirred for $3 \mathrm{~h}$ at $100^{\circ} \mathrm{C}$ in an oil bath. The reaction mixture was concentrated under vacuum. Purification by silica gel flash chromatography eluting with $25 \%$ ethyl acetate-petroleum ether afforded the title compound $(135 \mathrm{mg}, 82 \%)$ as a yellow solid. LCMS-ESI (m/z): $[\mathrm{M}+\mathrm{H}]^{+}$calcd for $\mathrm{C}_{13} \mathrm{H}_{12} \mathrm{~N}_{3} \mathrm{O}_{2}, 242.1$; found 242.2.<smiles>OCCC1c2ccccc2-n2nncc21</smiles>

2-[4H-[1,2,3]triazolo[1,5- $a]$ indol-4-yl]ethan-1-ol (6): To a solution of ethyl 2-[(4Z)-4H$[1,2,3]$ triazolo[1,5- $a$ indol-4-ylidene]acetate $(\mathbf{5 1}, 200 \mathrm{mg}, 0.83 \mathrm{mmol})$ in methanol $(20 \mathrm{~mL})$ was added sodium borohydride $(1.5 \mathrm{~g}, 40 \mathrm{mmol})$. The resulting solution was stirred for $2 \mathrm{~h}$ at ambient temperature. The reaction was then quenched by the addition of water. The resulting mixture was extracted with ethyl acetate and the organic layers were combined. The organic solution was concentrated. under vacuum. Purification by silica gel flash chromatography eluting with $50 \%$ dichloromethane-ethyl acetate afforded the title compound $(30 \mathrm{mg}, 18 \%)$ as a yellow solid. LCMS-ESI (m/z): $[\mathrm{M}+\mathrm{H}]^{+}$calcd for $\mathrm{C}_{11} \mathrm{H}_{12} \mathrm{~N}_{3} \mathrm{O}, 202.1$; found 202.1. ${ }^{1} \mathrm{H}$ NMR $(300 \mathrm{MHz}$, DMSO- $\left.d_{6}\right) \delta 7.91-7.83(\mathrm{~m}, 2 \mathrm{H}), 7.72(\mathrm{~d}, J=7.5 \mathrm{~Hz}, 1 \mathrm{H}), 7.53(\mathrm{t}, J=7.6 \mathrm{~Hz}, 1 \mathrm{H}), 7.48-7.39$ $(\mathrm{m}, 1 \mathrm{H}), 4.83(\mathrm{t}, J=5.1 \mathrm{~Hz}, 1 \mathrm{H}), 4.37(\mathrm{dd}, J=10.0,5.0 \mathrm{~Hz}, 1 \mathrm{H}), 3.79-3.47(\mathrm{~m}, 2 \mathrm{H}), 2.39-$ $2.15(\mathrm{~m}, 1 \mathrm{H}), 1.74-1.50(\mathrm{~m}, 1 \mathrm{H})$.

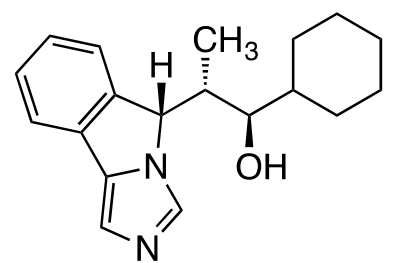

(1R,2S)-1-cyclohexyl-2-((S)-5H-imidazo[5,1-a] isoindol-5-yl)propan-1-ol (8). LCMS-ESI $(\mathrm{m} / \mathrm{z}):[\mathrm{M}+\mathrm{H}]^{+}$calcd for $\mathrm{C}_{19} \mathrm{H}_{25} \mathrm{~N}_{2} \mathrm{O}, 297.2$; found 297.1. ${ }^{1} \mathrm{H}$ NMR (300 MHz, methanol- $\left.d_{4}\right) \delta$ $9.15(\mathrm{~s}, 1 \mathrm{H}), 7.86(\mathrm{~d}, J=7.2 \mathrm{~Hz}, 1 \mathrm{H}), 7.80-7.64(\mathrm{~m}, 2 \mathrm{H}), 7.59-7.46(\mathrm{~m}, 2 \mathrm{H}), 6.12(\mathrm{~s}, 1 \mathrm{H})$, $3.66(\mathrm{~d}, J=10.3 \mathrm{~Hz}, 1 \mathrm{H}), 2.71(\mathrm{~d}, J=6.4 \mathrm{~Hz}, 1 \mathrm{H}), 1.94-1.44(\mathrm{~m}, 7 \mathrm{H}), 1.39-1.11(\mathrm{~m}, 5 \mathrm{H})$, $0.28(\mathrm{~d}, J=6.8 \mathrm{~Hz}, 3 \mathrm{H})$. Chiral HPLC: $\mathrm{t}_{\mathrm{R}}=7.412 \mathrm{~min}$, Chiral ADH, $15 \%$ hexanes $(0.1 \%$ diethanolamine)-isopropyl acetate. 


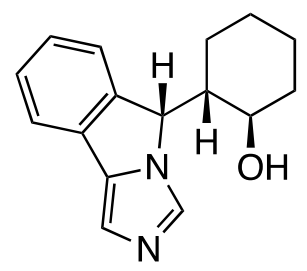

(1R,2S)-2-((S)-5H-imidazo[5,1-a]isoindol-5-yl)cyclohexan-1-ol (9). LCMS-ESI (m/z): [M+H] $]^{+}$ calcd for $\mathrm{C}_{16} \mathrm{H}_{19} \mathrm{~N}_{2} \mathrm{O}, 255.2$; found 255.1. ${ }^{1} \mathrm{H}$ NMR (400 MHz, DMSO- $\left.d_{6}\right) \delta 7.88(\mathrm{~s}, 1 \mathrm{H}), 7.66$ $(\mathrm{d}, J=7.5 \mathrm{~Hz}, 1 \mathrm{H}), 7.58(\mathrm{~d}, J=7.5 \mathrm{~Hz}, 1 \mathrm{H}), 7.40-7.32(\mathrm{~m}, 1 \mathrm{H}), 7.27-7.18(\mathrm{~m}, 1 \mathrm{H}), 7.10(\mathrm{~s}$, $1 \mathrm{H}), 5.16(\mathrm{~d}, J=5.4 \mathrm{~Hz}, 1 \mathrm{H}), 4.69(\mathrm{~d}, J=4.0 \mathrm{~Hz}, 1 \mathrm{H}), 4.09-4.04(\mathrm{~m}, 1 \mathrm{H}), 1.82-1.30(\mathrm{~m}, 7 \mathrm{H})$, $1.18-1.10(\mathrm{~m}, 1 \mathrm{H})$. Chiral SFC: $\mathrm{t}_{\mathrm{R}}=1.739 \mathrm{~min}$, Chiral Art, $10 \%$ methanol $(0.1 \%$ ammonium hydroxide)-carbon dioxide.

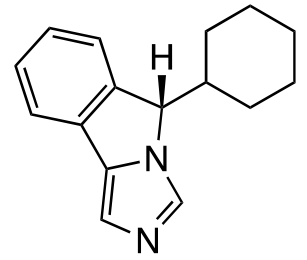

(S)-5-cyclohexyl-5H-imidazo[5,1-a]isoindole (10). To a solution of $5 H$-imidazo[5,1- $a$ ]isoindole $(\mathbf{6 5}, 502 \mathrm{mg}, 3.2 \mathrm{mmol})$ in tetrahydrofuran $(21 \mathrm{~mL})$ at $-78^{\circ} \mathrm{C}$ was added $s$-butyllithium $(1.4 \mathrm{M}$ in cyclohexane, $2.5 \mathrm{~mL}, 3.5 \mathrm{mmol}$ ) over $5 \mathrm{~min}$. The solution was stirred for $1 \mathrm{~h}$ at $-78^{\circ} \mathrm{C}$. A solution of bromocyclohexane $(524 \mathrm{mg}, 3.2 \mathrm{mmol})$ in tetrahydrofuran $(3 \mathrm{~mL})$ was added down the side of the flask. The reaction was stirred for $1 \mathrm{~h}$ at $-78^{\circ} \mathrm{C}$ and allowed to warm to ambient temperature for $2 \mathrm{~h}$. The reaction was quenched by addition of saturated aqueous ammonium chloride solution. The biphasic mixture was extracted with dichloromethane. The organic layer was dried over anhydrous sodium sulfate. The solvent was removed under vacuum. Purification by silica gel flash chromatography with 0-5\% methanol-dichloromethane afforded the title compound as a tan solid (306 mg, 49\%). LCMS-ESI (m/z): $[\mathrm{M}+\mathrm{H}]^{+}$calcd for $\mathrm{C}_{16} \mathrm{H}_{19} \mathrm{~N}_{2}, 239.2$; found 239.1. ${ }^{1} \mathrm{H}$ NMR (400 MHz, DMSO-d 6$) \delta 7.88(\mathrm{~s}, 1 \mathrm{H}), 7.58(\mathrm{~d}, J=7.4 \mathrm{~Hz}, 1 \mathrm{H}), 7.49(\mathrm{dd}, J$ $=7.7,1.1 \mathrm{~Hz}, 1 \mathrm{H}), 7.37(\mathrm{td}, J=7.4,1.4 \mathrm{~Hz}, 1 \mathrm{H}), 7.27(\mathrm{td}, J=7.5,1.2 \mathrm{~Hz}, 1 \mathrm{H}), 7.12(\mathrm{~s}, 1 \mathrm{H}), 5.25$ $(\mathrm{d}, J=2.8 \mathrm{~Hz}, 1 \mathrm{H}), 2.12(\mathrm{tdd}, J=15.3,7.7,4.7 \mathrm{~Hz}, 1 \mathrm{H}), 1.71(\mathrm{dq}, J=12.0,2.8 \mathrm{~Hz}, 1 \mathrm{H}), 1.58$ $(\mathrm{td}, J=11.2,4.9 \mathrm{~Hz}, 2 \mathrm{H}), 1.34-0.93(\mathrm{~m}, 3 \mathrm{H}), 0.66(\mathrm{qd}, J=12.3,3.3 \mathrm{~Hz}, 1 \mathrm{H})$. Chiral SFC: $\mathrm{t}_{\mathrm{R}}=$ 1.154 min, Trefoil Amy-1, 10\% methanol (0.1\% ammonium hydroxide)-carbon dioxide.

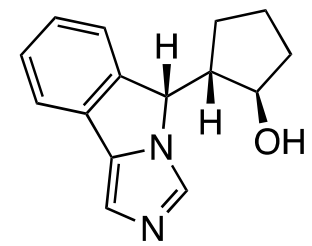

$(1 R, 2 S)-2-((S)-5 H$-imidazo[5,1-a]isoindol-5-yl)cyclopentan-1-ol (11). LCMS-ESI (m/z): $[\mathrm{M}+\mathrm{H}]^{+}$calcd for $\mathrm{C}_{15} \mathrm{H}_{17} \mathrm{~N}_{2} \mathrm{O}, 241.1$; found 241.1. ${ }^{1} \mathrm{H}$ NMR (400 MHz, DMSO- $\left.d_{6}\right) \delta 7.90(\mathrm{~s}$, $1 \mathrm{H}), 7.61(\mathrm{dd}, J=22.5,7.6 \mathrm{~Hz}, 2 \mathrm{H}), 7.37(\mathrm{t}, J=7.5 \mathrm{~Hz}, 1 \mathrm{H}), 7.31-7.23(\mathrm{~m}, 1 \mathrm{H}), 5.39(\mathrm{~d}, J=$ $6.8 \mathrm{~Hz}, 1 \mathrm{H}), 5.16(\mathrm{~d}, J=3.8 \mathrm{~Hz}, 1 \mathrm{H}), 4.37(\mathrm{q}, J=4.7 \mathrm{~Hz}, 1 \mathrm{H}), 2.14-2.01(\mathrm{~m}, 1 \mathrm{H}), 1.84-1.39$ $(\mathrm{m}, 7 \mathrm{H})$. Chiral SFC: $\mathrm{t}_{\mathrm{R}}=0.458 \mathrm{~min}$, Chiralpak AD, $20 \%$ methanol $(0.1 \%$ ammonium hydroxide)-carbon dioxide. 


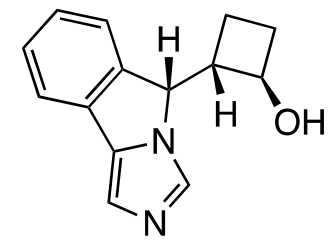

(1R,2S)-2-((S)-5H-imidazo[5,1-a]isoindol-5-yl)cyclobutan-1-ol (12). LCMS-ESI (m/z): $[\mathrm{M}+\mathrm{H}]^{+}$calcd for $\mathrm{C}_{14} \mathrm{H}_{15} \mathrm{~N}_{2} \mathrm{O}, 227.1$; found 227.1. ${ }^{1} \mathrm{H}$ NMR $\left(400 \mathrm{MHz}, \mathrm{DMSO}-d_{6}\right) \delta 7.84(\mathrm{~s}$, $1 \mathrm{H}), 7.61-7.54(\mathrm{~m}, 2 \mathrm{H}), 7.36(\mathrm{t}, J=7.6 \mathrm{~Hz}, 1 \mathrm{H}), 7.31-7.21(\mathrm{~m}, 1 \mathrm{H}), 7.13(\mathrm{~s}, 1 \mathrm{H}), 5.34(\mathrm{dd}, J$ $=15.4,6.8 \mathrm{~Hz}, 2 \mathrm{H}), 4.25(\mathrm{p}, J=7.5 \mathrm{~Hz}, 1 \mathrm{H}), 3.39-3.30(\mathrm{~m}, 1 \mathrm{H}), 2.41(\mathrm{dq}, J=9.6,7.7 \mathrm{~Hz}, 1 \mathrm{H})$, $2.15-2.03(\mathrm{~m}, 1 \mathrm{H}), 1.73-1.50(\mathrm{~m}, 2 \mathrm{H}), 1.12(\mathrm{qd}, J=10.2,8.1 \mathrm{~Hz}, 1 \mathrm{H})$. Chiral SFC: $\mathrm{t}_{\mathrm{R}}=0.627$ min, Chiralpak AD, 20\% methanol (0.1\% ammonium hydroxide)-carbon dioxide.

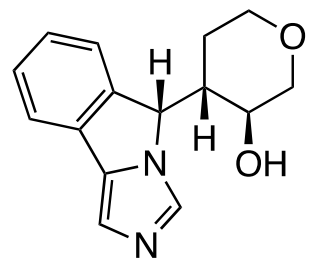

$(3 S, 4 S)-4-((S)-5 H$-imidazo[5,1-a]isoindol-5-yl)tetrahydro-2H-pyran-3-ol (13). LCMS-ESI $(\mathrm{m} / \mathrm{z}):[\mathrm{M}+\mathrm{H}]^{+}$calcd for $\mathrm{C}_{15} \mathrm{H}_{17} \mathrm{~N}_{2} \mathrm{O}_{2}, 257.1$; found $257.1 .{ }^{1} \mathrm{H}$ NMR $\left(300 \mathrm{MHz}, \mathrm{CDCl}_{3}\right) \delta 8.02$ (s, $1 \mathrm{H}), 7.55-7.53(\mathrm{~m}, 1 \mathrm{H}), 7.40-7.28(\mathrm{~m}, 3 \mathrm{H}), 7.20(\mathrm{~s}, 1 \mathrm{H}), 5.85(\mathrm{~d}, J=2.1 \mathrm{~Hz}, 1 \mathrm{H}), 4.16-$ 4.11(m, 1H), $4.07-3.97(\mathrm{~m}, 1 \mathrm{H}), 3.75-3.69(\mathrm{~m}, 1 \mathrm{H}), 3.27-3.12(\mathrm{~m}, 2 \mathrm{H}), 2.40-2.30(\mathrm{~m}, 1 \mathrm{H})$, $0.92-0.72(\mathrm{~m}, 2 \mathrm{H})$. Chiral HPLC: $\mathrm{t}_{\mathrm{R}}=3.201 \mathrm{~min}$, Chiralcel OJ-3, 85\% hexanes $(0.1 \%$ diethanolamine)-ethanol.

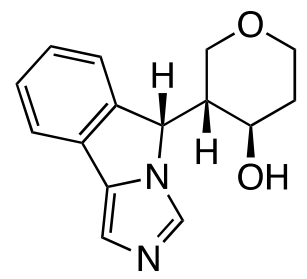

(3R,4R)-3-((S)-5H-imidazo[5,1-a]isoindol-5-yl)tetrahydro-2 $H$-pyran-4-ol (14). LCMS-ESI $(\mathrm{m} / \mathrm{z}):[\mathrm{M}+\mathrm{H}]^{+}$calcd for $\mathrm{C}_{15} \mathrm{H}_{17} \mathrm{~N}_{2} \mathrm{O}_{2}, 257.1$; found 257.1. ${ }^{1} \mathrm{H} \mathrm{NMR}\left(300 \mathrm{MHz}, \mathrm{CDCl}_{3}\right): \delta 7.80$ $(\mathrm{s}, 1 \mathrm{H}), 7.53-7.50(\mathrm{~m}, 1 \mathrm{H}), 7.39-7.24(\mathrm{~m}, 3 \mathrm{H}), 7.17(\mathrm{~s}, 1 \mathrm{H}), 5.82(\mathrm{~d}, J=2.1 \mathrm{~Hz}, 1 \mathrm{H}), 4.14-$ $4.06(\mathrm{~m}, 1 \mathrm{H}), 3.94-3.89(\mathrm{~m}, 1 \mathrm{H}), 3.31-3.21(\mathrm{~m}, 2 \mathrm{H}), 2.57-2.49(\mathrm{~m}, 1 \mathrm{H}), 2.42-2.33(\mathrm{~m}$, $1 \mathrm{H}), 2.11-2.05(\mathrm{~m}, 1 \mathrm{H}), 1.90-1.77(\mathrm{~m}, 1 \mathrm{H})$. Chiral HPLC: $\mathrm{t}_{\mathrm{R}}=4.958 \mathrm{~min}$, Chiralpak OJ-3, $85 \%$ hexanes $(0.1 \%$ diethanolamine $)$-ethanol.

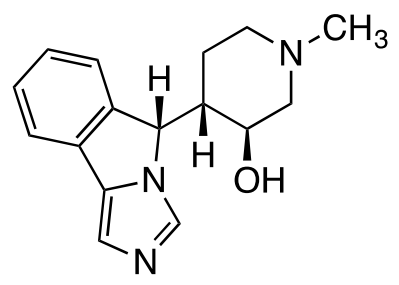

(3S,4S)-4-((S)-5H-imidazo[5,1-a]isoindol-5-yl)-1-methylpiperidin-3-ol (15). LCMS-ESI $(\mathrm{m} / \mathrm{z}):[\mathrm{M}+\mathrm{H}]^{+}$calcd for $\mathrm{C}_{16} \mathrm{H}_{20} \mathrm{~N}_{3} \mathrm{O}, 270.2$; found $270.1 .{ }^{1} \mathrm{H}$ NMR $\left(300 \mathrm{MHz}, \mathrm{CD}_{3} \mathrm{OD}\right): \delta 7.92$ $(\mathrm{s}, 1 \mathrm{H}), 7.63(\mathrm{~d}, J=7.5 \mathrm{~Hz}, 1 \mathrm{H}), 7.47(\mathrm{~d}, J=7.5 \mathrm{~Hz}, 1 \mathrm{H}), 7.42-7.33(\mathrm{~m}, 2 \mathrm{H}), 7.19(\mathrm{~s}, 1 \mathrm{H}), 5.80$ $(\mathrm{d}, J=3.3 \mathrm{~Hz}, 1 \mathrm{H}), 3.97-3.90(\mathrm{~m}, 1 \mathrm{H}), 3.18-3.13(\mathrm{~m}, 1 \mathrm{H}), 2.70-2.62(\mathrm{~m}, 1 \mathrm{H}), 2.63(\mathrm{~s}, 3 \mathrm{H})$, 
$2.06-1.83(\mathrm{~m}, 3 \mathrm{H}), 0.91-0.86(\mathrm{~m}, 1 \mathrm{H}), 0.72-0.64(\mathrm{~m}, 1 \mathrm{H})$. ). Chiral HPLC: $\mathrm{t}_{\mathrm{R}}=5.153 \mathrm{~min}$, Chiralpak AD-H, $60 \%$ hexanes $(0.1 \%$ diethanolamine $)$-ethanol.

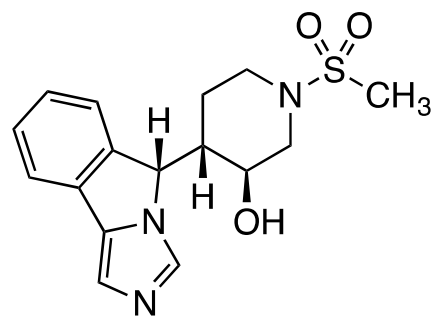

(3S,4S)-4-((S)-5H-imidazo[5,1-a]isoindol-5-yl)-1-(methylsulfonyl)piperidin-3-ol (16). LCMS$\operatorname{ESI}(\mathrm{m} / \mathrm{z}):[\mathrm{M}+\mathrm{H}]^{+}$calcd for $\mathrm{C}_{16} \mathrm{H}_{20} \mathrm{~N}_{3} \mathrm{O}_{3} \mathrm{~S}, 334.1$; found 334.1. ${ }^{1} \mathrm{H}$ NMR (300 MHz, DMSO- $\left.d_{6}\right)$ : $\delta 7.92(\mathrm{~s}, 1 \mathrm{H}), 7.63(\mathrm{~d}, J=7.8 \mathrm{~Hz}, 1 \mathrm{H}), 7.52(\mathrm{~d}, J=7.8 \mathrm{~Hz}, 1 \mathrm{H}), 7.44-7.27(\mathrm{~m}, 2 \mathrm{H}), 7.15(\mathrm{~s}$, $1 \mathrm{H}), 5.81(\mathrm{~d}, J=3.6 \mathrm{~Hz}, 1 \mathrm{H}), 5.79(\mathrm{~d}, J=3.6 \mathrm{~Hz}, 1 \mathrm{H}), 3.84-3.71(\mathrm{~m}, 2 \mathrm{H}), 3.34-3.29(\mathrm{~m}, 1 \mathrm{H})$, $2.84(\mathrm{~s}, 3 \mathrm{H}), 2.55-2.51(\mathrm{~m}, 1 \mathrm{H}), 2.49-2.48(\mathrm{~m}, 2 \mathrm{H}), 2.34-2.21(\mathrm{~m}, 1 \mathrm{H}), 0.71-0.66(\mathrm{~m}, 1 \mathrm{H})$, $0.55-0.54(\mathrm{~m}, 1 \mathrm{H})$. Chiral HPLC: $\mathrm{t}_{\mathrm{R}}=2.022 \mathrm{~min}$, Chiralpak IC-3, 50\% hexanes $(0.1 \%$ diethanolamine)-ethanol.<smiles></smiles>

1-((3S,4S)-3-hydroxy-4-((S)-5H-imidazo[5,1-a]isoindol-5-yl)piperidin-1-yl)ethan-1-one (17). LCMS-ESI (m/z): $[\mathrm{M}+\mathrm{H}]^{+}$calcd for $\mathrm{C}_{17} \mathrm{H}_{20} \mathrm{~N}_{3} \mathrm{O}_{2}$, 298.2; found 298.2. ${ }^{1} \mathrm{H}$ NMR $(300 \mathrm{MHz}$, $\left.\mathrm{CD}_{3} \mathrm{OD}\right): \delta 7.95-7.90(\mathrm{~m}, 1 \mathrm{H}), 7.64-7.62(\mathrm{~m}, 1 \mathrm{H}), 7.52-7.36(\mathrm{~m}, 3 \mathrm{H}), 7.20(\mathrm{~s}, 1 \mathrm{H}), 5.84-$ $5.83(\mathrm{~m}, 1 \mathrm{H}), 4.88-4.78(\mathrm{~m}, 1 \mathrm{H}), 4.34-4.08(\mathrm{~m}, 1 \mathrm{H}), 3.83-3.67(\mathrm{~m}, 2 \mathrm{H}), 3.06-2.85(\mathrm{~m}$, $1 \mathrm{H}), 2.55-2.28(\mathrm{~m}, 2 \mathrm{H}), 2.14-1.98(\mathrm{~m}, 3 \mathrm{H}), 1.00-0.85(\mathrm{~m}, 1 \mathrm{H}), 0.59-0.58(\mathrm{~m}, 1 \mathrm{H})$. Chiral HPLC: $\mathrm{t}_{\mathrm{R}}=10.807 \mathrm{~min}$, Chiralpak OD-3, 93\% hexanes (0.1\% diethanolamine)-ethanol.

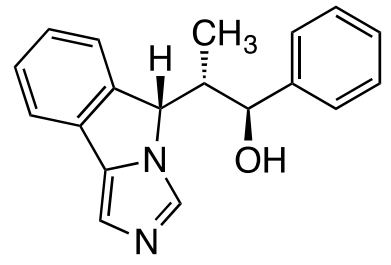

(1S,2S)-2-((S)-5H-imidazo[5,1-a]isoindol-5-yl)-1-phenylpropan-1-ol (18). LCMS-ESI (m/z): $[\mathrm{M}+\mathrm{H}]^{+}$calcd for $\mathrm{C}_{19} \mathrm{H}_{19} \mathrm{~N}_{2} \mathrm{O}, 291.2$; found 291.1. ${ }^{1} \mathrm{H}$ NMR (DMSO-d6): $\delta 7.74(\mathrm{~s}, 1 \mathrm{H}), 7.61-$ $7.46(\mathrm{~m}, 4 \mathrm{H}), 7.38(\mathrm{dt}, J=15.0,7.5 \mathrm{~Hz}, 3 \mathrm{H}), 7.33-7.21(\mathrm{~m}, 2 \mathrm{H}), 7.10(\mathrm{~s}, 1 \mathrm{H}), 5.69(\mathrm{~d}, J=4.3$ $\mathrm{Hz}, 1 \mathrm{H}), 5.20$ (s, 1H), $5.02(\mathrm{t}, J=4.9 \mathrm{~Hz}, 1 \mathrm{H}), 2.57$ (ddd, $J=7.2,5.6,1.7 \mathrm{~Hz}, 1 \mathrm{H}), 0.30(\mathrm{~d}, J=$ $6.9 \mathrm{~Hz}, 3 \mathrm{H})$. Chiral SFC: $\mathrm{t}_{\mathrm{R}}=3.167 \mathrm{~min}$, Trefoil Cel-1, 22\% methanol $(0.1 \%$ ammonium hydroxide)-carbon dioxide. 


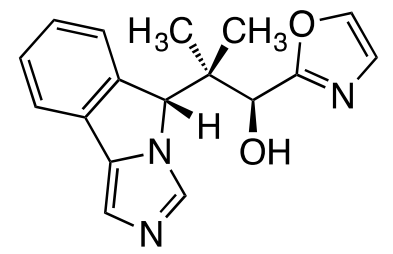

$(S)-2-((R)-5 H$-imidazo[5,1-a] isoindol-5-yl)-2-methyl-1-(oxazol-2-yl)propan-1-ol (19).<smiles>CCOC(=O)C(C)(C)C(O)c1ccccc1-c1cn(CC)cn1</smiles>

ethyl 3-hydroxy-2,2-dimethyl-3-(2-(1-trityl-1H-imidazol-4-yl)phenyl)propanoate (72): A solution of $n$-butyllithium $(2.5 \mathrm{M}, 2.3 \mathrm{~mL}, 5.8 \mathrm{mmol})$ in hexanes was added to a stirred solution of $N, N$-diisopropylamine $(0.88 \mathrm{~mL}, 6.3 \mathrm{mmol})$ in tetrahydrofuran $(20 \mathrm{~mL})$ at $0{ }^{\circ} \mathrm{C}$. The mixture was stirred for $20 \mathrm{~min}$ at $0{ }^{\circ} \mathrm{C}$. A solution of ethyl 2-methylpropanoate $(0.78 \mathrm{~mL}, 5.8 \mathrm{mmol})$ in tetrahydrofuran $(2 \mathrm{~mL})$ was added to the reaction vessel at $-78^{\circ} \mathrm{C}$. The mixture was stirred for 40 min at $-78^{\circ} \mathrm{C}$. A solution of 2-(1-trityl- $1 H$-imidazol-4-yl)benzaldehyde $(\mathbf{5 2}, 1.00 \mathrm{~g}, 2.4 \mathrm{mmol})$ in tetrahydrofuran $(7 \mathrm{~mL})$ was added to the reaction vessel at $-40^{\circ} \mathrm{C}$. The mixture was stirred for 1 $\mathrm{h}$ at $-40^{\circ} \mathrm{C}$. The reaction was quenched by addition of saturated aqueous ammonium chloride solution. The quenched mixture was partitioned between water and ethyl acetate. The organic layer was washed with water and dried over anhydrous sodium sulfate. Purification by silica gel flash chromatography with $25-50 \%$ ethyl acetate-heptane afforded the title compound ( $1.1 \mathrm{~g}$, $86 \%)$ as a yellow solid. LCMS-ESI (m/z): $[\mathrm{M}+\mathrm{H}]^{+}$calcd for $\mathrm{C}_{35} \mathrm{H}_{35} \mathrm{~N}_{2} \mathrm{O}_{3}, 531.3$; found 531.5.<smiles>CCOC(=O)C(C)(C)C(O)c1ccccc1-c1c[nH]cn1</smiles>

ethyl 3-(2-(1H-imidazol-4-yl)phenyl)-3-hydroxy-2,2-dimethylpropanoate (73): Acetic acid (15 $\mathrm{mL}$ ) was added to a stirred solution of ethyl 3-hydroxy-2,2-dimethyl-3-(2-(1-trityl-1H-imidazol4-yl)phenyl)propanoate (72, $5.50 \mathrm{~g}, 10 \mathrm{mmol})$ in methanol $(35 \mathrm{~mL})$. The reaction was stirred for $5 \mathrm{~h}$ at $80^{\circ} \mathrm{C}$. The mixture was concentrated under vacuum. The residue was partitioned between water and ethyl acetate. The organic layer was washed with water and dried over anhydrous sodium sulfate. Purification by silica gel flash chromatography with 1-15\% methanoldichloromethane afforded the title compound $(3.0 \mathrm{~g},>99 \%)$ as a yellow solid. LCMS-ESI (m/z): $[\mathrm{M}+\mathrm{H}]^{+}$calcd for $\mathrm{C}_{16} \mathrm{H}_{21} \mathrm{~N}_{2} \mathrm{O}_{3}$, 289.2; found 289.2.<smiles>CCOC(=O)C(C)(C)C1c2ccccc2-c2cncn21</smiles>

ethyl 2-(5H-imidazo[5,1- $a$ ]isoindol-5-yl)-2-methylpropanoate (74): Ethyl 3-(2-(1H-imidazol-4yl)phenyl)-3-hydroxy-2,2-dimethylpropanoate $(\mathbf{7 3}, 525 \mathrm{mg} 1.8 \mathrm{mmol})$ was added to a stirred solution of cyanomethylene trimethylphosphorane $(0.5 \mathrm{M}, 10 \mathrm{~mL}, 5 \mathrm{mmol})$ in tetrahydrofuran. The reaction was stirred for $12 \mathrm{~h}$ at ambient temperature. The mixture was partitioned between 
water and ethyl acetate. The organic layer was washed with water and dried over anhydrous sodium sulfate. Purification by silica gel flash chromatography with $1-15 \%$ methanoldichloromethane afforded the title compound $(410 \mathrm{mg}, 83 \%)$ as a yellow solid. LCMS-ESI $(\mathrm{m} / \mathrm{z}):[\mathrm{M}+\mathrm{H}]^{+}$calcd for $\mathrm{C}_{1} \wedge \mathrm{H}_{19} \mathrm{~N}_{2} \mathrm{O}_{2}, 271.1$; found 271.3.

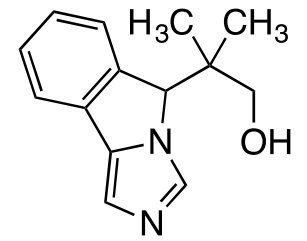

2-(5H-imidazo[5,1-a]isoindol-5-yl)-2-methylpropan-1-ol (75): A solution of diisobutylaluminum hydride $(1 \mathrm{M}, 22 \mathrm{~mL}, 22 \mathrm{mmol})$ in toluene was added to a stirred solution of ethyl $2-(5 \mathrm{H}-$ imidazo[5,1-a]isoindol-5-yl)-2-methylpropanoate (74, $1.20 \mathrm{~g}, 4.4 \mathrm{mmol})$ in tetrahydrofuran (10 $\mathrm{mL}$ ) at $0^{\circ} \mathrm{C}$. The mixture was allowed to warm to ambient temperature for $2 \mathrm{~h}$. The reaction was quenched by addition of saturated aqueous ammonium chloride solution. The biphasic mixture was partitioned between water and ethyl acetate. The organic layer was washed with water and dried over anhydrous sodium sulfate. The solvent was removed under vacuum. Purification by silica gel flash chromatography with 1-15\% methanol-dichloromethane afforded the title compound $(700 \mathrm{mg}, 69 \%)$ as a pale yellow solid. LCMS-ESI $(\mathrm{m} / \mathrm{z}):[\mathrm{M}+\mathrm{H}]^{+}$calcd for $\mathrm{C}_{14} \mathrm{H}_{17} \mathrm{~N}_{2} \mathrm{O}$, 229.1; found 229.1.<smiles>CC(C)(C=O)C1c2ccccc2-c2cncn21</smiles>

2-(5H-imidazo[5,1-a]isoindol-5-yl)-2-methylpropanal (76): A solution of Dess-Martin periodinane $(19.0 \mathrm{~g}, 44 \mathrm{mmol})$ in dichloromethane $(50 \mathrm{~mL})$ was added to a stirred solution of 2 (5H-imidazo[5,1-a]isoindol-5-yl)-2-methylpropan-1-ol (75, 5.00 g, $22 \mathrm{mmol}$ ) in dichloromethane $(50 \mathrm{~mL})$. Following addition, sodium bicarbonate $(5.80 \mathrm{~g}, 66 \mathrm{mmol})$ was added. The suspension was stirred for $3 \mathrm{~h}$ at ambient temperature. The reaction mixture was concentrated under vacuum. The residue was partitioned between water and ethyl acetate. The organic layer was washed with water and dried over anhydrous sodium sulfate. The solvent was removed under vacuum. Purification by silica gel flash chromatography with $1-15 \%$ methanoldichloromethane afforded the title compound $(4.1 \mathrm{~g}, 83 \%)$ as a yellow solid. LCMS-ESI (m/z): $[\mathrm{M}+\mathrm{H}]^{+}$calcd for $\mathrm{C}_{14} \mathrm{H}_{15} \mathrm{~N}_{2} \mathrm{O}, 227.1$; found 227.1 .

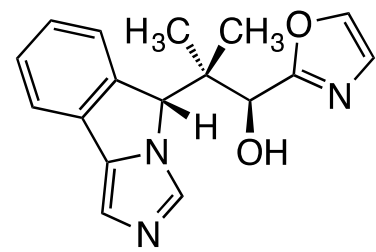

(S)-2-((R)-5H-imidazo[5,1-a]isoindol-5-yl)-2-methyl-1-(oxazol-2-yl)propan-1-ol (19): A solution of oxazole (95 mg, $1.4 \mathrm{mmol})$ and borane-tetrahydrofuran complex (1 M in tetrahydrofuran, $1.4 \mathrm{~mL}, 1.4 \mathrm{mmol})$ in tetrahydrofuran $(0.50 \mathrm{~mL})$ was stirred for $30 \mathrm{~min}$ at ambient temperature. The solution was cooled to $-78^{\circ} \mathrm{C}$. $n$-Butyllithium $(2.5 \mathrm{M}$ in hexanes, 0.54 $\mathrm{mL}, 1.4 \mathrm{mmol})$ was added. The mixture was stirred for $30 \mathrm{~min}$ at $-78^{\circ} \mathrm{C}$. A solution of $2-(5 \mathrm{H}-$ imidazo[5,1-a] isoindol-5-yl)-2-methylpropanal (76, $77 \mathrm{mg}, 0.34 \mathrm{mmol})$ in tetrahydrofuran $(0.20$ $\mathrm{mL}$ ) was added. The reaction was then stirred for $1 \mathrm{~h}$ at $-40^{\circ} \mathrm{C}$. The reaction was quenched with 
water and extracted with ethyl acetate. The organic layer was washed with water and dried over anhydrous sodium sulfate. The solvent was removed under vacuum. Purification by silica gel flash chromatography with 1-10\% methanol-dichloromethane afforded the title compound (30 $\mathrm{mg}, 29 \%$ ) as a mixture of diastereomers. LCMS-ESI (m/z): $[\mathrm{M}+\mathrm{H}]^{+}$calcd for $\mathrm{C}_{17} \mathrm{H}_{18} \mathrm{~N}_{3} \mathrm{O}_{2}$, 296.1; found 296.1. ${ }^{1} \mathrm{H}$ NMR (400 MHz, DMSO- $\left.d_{6}\right): \delta 7.46-7.36(\mathrm{~m}, 1 \mathrm{H}), 7.31-7.21(\mathrm{~m}, 2 \mathrm{H})$, $7.17(\mathrm{~s}, 1 \mathrm{H}), 6.35(\mathrm{~d}, 4.7 \mathrm{~Hz}, 1 \mathrm{H}), 1.10(\mathrm{~s}, 3 \mathrm{H}), 0.32(\mathrm{~s}, 3 \mathrm{H})$. Chiral SFC: $\mathrm{t}_{\mathrm{R}}=0.858 \mathrm{~min}$, Trefoil Cel-4, 25\% methanol (0.1\% ammonium hydroxide)-carbon dioxide.<smiles>CC1(C2c3ccccc3-c3cncn32)CCc2ccncc2C1O</smiles>

(7S,8S)-7-((S)-5H-imidazo[5,1-a]isoindol-5-yl)-5,6,7,8-tetrahydroisoquinolin-8-ol (20). LCMS-ESI (m/z): $[\mathrm{M}+\mathrm{H}]^{+}$calcd for $\mathrm{C}_{19} \mathrm{H}_{18} \mathrm{~N}_{3} \mathrm{O}$, 304.1; found 304.1. ${ }^{1} \mathrm{H}$ NMR $(300 \mathrm{MHz}$, $\left.\mathrm{CD}_{3} \mathrm{OD}\right): \delta 8.79(\mathrm{~s}, 1 \mathrm{H}), 8.27(\mathrm{~d}, J=5.1 \mathrm{~Hz}, 1 \mathrm{H}), 7.99(\mathrm{~s}, 1 \mathrm{H}), 7.66-7.64(\mathrm{~m}, 1 \mathrm{H}), 7.50-7.32$ $(\mathrm{m}, 3 \mathrm{H}), 7.20(\mathrm{~s}, 1 \mathrm{H}), 7.18(\mathrm{~d}, J=5.1 \mathrm{~Hz}, 1 \mathrm{H}), 5.89(\mathrm{~d}, J=3.0 \mathrm{~Hz}, 1 \mathrm{H}), 5.10(\mathrm{~d}, J=10.5 \mathrm{~Hz}$, $1 \mathrm{H}), 2.70-2.68(\mathrm{~m}, 2 \mathrm{H}), 2.50-2.42(\mathrm{~m}, 1 \mathrm{H}), 1.14-0.98(\mathrm{~m}, 2 \mathrm{H})$. Chiral SFC: $\mathrm{t}_{\mathrm{R}}=1.182 \mathrm{~min}$, Trefoil Amy-4, 25\% methanol (0.1\% ammonium hydroxide)-carbon dioxide.

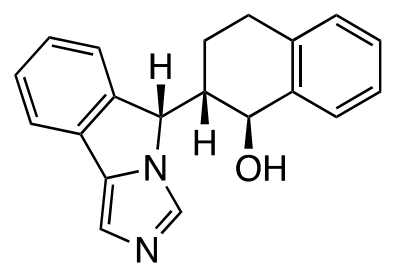

(1S,2S)-2-((S)-5H-imidazo[5,1-a]isoindol-5-yl)-1,2,3,4-tetrahydronaphthalen-1-ol (21). LCMS-ESI (m/z): $[\mathrm{M}+\mathrm{H}]^{+}$calcd for $\mathrm{C}_{20} \mathrm{H}_{19} \mathrm{~N}_{2} \mathrm{O}$, 303.2; found 303.1. ${ }^{1} \mathrm{HNMR}(400 \mathrm{MHz}$, DMSO-d $)): 7.96(\mathrm{~s}, 1 \mathrm{H}), 7.66(\mathrm{~d}, J=7.7 \mathrm{~Hz}, 1 \mathrm{H}), 7.63(\mathrm{~d}, J=7.4 \mathrm{~Hz}, 1 \mathrm{H}), 7.50-7.46(\mathrm{~m}, 1 \mathrm{H})$, $7.41(\mathrm{t}, J=7.4 \mathrm{~Hz}, 1 \mathrm{H}), 7.31(\mathrm{td}, J=7.5,1.2 \mathrm{~Hz}, 1 \mathrm{H}), 7.23(\mathrm{td}, J=7.5,1.2 \mathrm{~Hz}, 1 \mathrm{H}), 7.18(\mathrm{~s}$, $1 \mathrm{H}), 7.14(\mathrm{td}, J=7.4,1.4 \mathrm{~Hz}, 1 \mathrm{H}), 7.00(\mathrm{dd}, J=7.5,1.3 \mathrm{~Hz}, 1 \mathrm{H}), 5.97(\mathrm{~d}, J=7.7 \mathrm{~Hz}, 1 \mathrm{H}), 5.84$ $-5.78(\mathrm{~m}, 1 \mathrm{H}), 4.93(\mathrm{dd}, J=10.6,7.8 \mathrm{~Hz}), 2.56(\mathrm{~s}, 3 \mathrm{H}), 2.38(\mathrm{tt}, J=11.2,2.9 \mathrm{~Hz}, 1 \mathrm{H}), 0.95-$ $0.73(\mathrm{~m}, 2 \mathrm{H})$. Chiral HPLC: $\mathrm{t}_{\mathrm{R}}=7.284 \mathrm{~min}$, Daicel OZ-H, 90\% hexanes $(0.1 \%$ diethanolamine $)$ ethanol.<smiles>CC1(C2c3ccccc3-c3cncn32)CCc2cnccc2C1O</smiles>

(5S,6S)-6-((S)-5H-imidazo[5,1-a] isoindol-5-yl)-5,6,7,8-tetrahydroisoquinolin-5-ol (22). LCMS-ESI (m/z): $[\mathrm{M}+\mathrm{H}]^{+}$calcd for $\mathrm{C}_{19} \mathrm{H}_{18} \mathrm{~N}_{3} \mathrm{O}, 304.1$; found 304.2. ${ }^{1} \mathrm{H}$ NMR $(300 \mathrm{MHz}$, $\left.\mathrm{CD}_{3} \mathrm{OD}\right): \delta 8.39-8.37(\mathrm{~m}, 1 \mathrm{H}), 8.23(\mathrm{~s}, 1 \mathrm{H}), 8.04(\mathrm{~s}, 1 \mathrm{H}), 7.72-7.66(\mathrm{~m}, 2 \mathrm{H}), 7.51-7.35(\mathrm{~m}$, $3 \mathrm{H}), 7.24(\mathrm{~s}, 1 \mathrm{H}), 5.91(\mathrm{~s}, 1 \mathrm{H}), 5.04(\mathrm{~d}, J=5.4 \mathrm{~Hz}, 1 \mathrm{H}), 2.71-2.68(\mathrm{~m}, 2 \mathrm{H}), 2.53-2.46(\mathrm{~m}$, $1 \mathrm{H}), 1.20-1.17(\mathrm{~m}, 1 \mathrm{H}), 1.08-0.94(\mathrm{~m}, 1 \mathrm{H})$. Chiral SFC: $\mathrm{t}_{\mathrm{R}}=1.397 \mathrm{~min}$, Chiralpak AS-3, 10$50 \%$ methanol $(0.1 \%$ ammonium hydroxide $)$-carbon dioxide. 


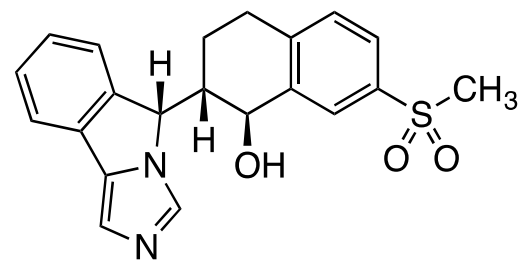

$(1 S, 2 S)-2-((S)-5 H$-imidazo[5,1-a]isoindol-5-yl)-7-(methylsulfonyl)-1,2,3,4tetrahydronaphthalen-1-ol (23). LCMS-ESI (m/z): $[\mathrm{M}+\mathrm{H}]^{+}$calcd for $\mathrm{C}_{21} \mathrm{H}_{21} \mathrm{~N}_{2} \mathrm{O}_{3} \mathrm{~S}, 381.1$; found 381.1. ${ }^{1} \mathrm{HNMR}\left(500 \mathrm{MHz}, \mathrm{DMSO}-d_{6}\right): \delta 8.29(\mathrm{~s}, 1 \mathrm{H}), 8.18(\mathrm{dd}, J=2.2,0.9 \mathrm{~Hz}, 1 \mathrm{H}), 7.73$ $-7.68(\mathrm{~m}, 2 \mathrm{H}), 7.53(\mathrm{dq}, J=7.7,1.0 \mathrm{~Hz}, 1 \mathrm{H}), 7.46(\mathrm{tt}, J=7.6,0.8 \mathrm{~Hz}, 1 \mathrm{H}), 7.37$ (td, $J=7.5,1.1$ $\mathrm{Hz}, 2 \mathrm{H}), 7.31(\mathrm{~d}, J=8.0 \mathrm{~Hz}, 1 \mathrm{H}), 6.27(\mathrm{~d}, J=7.7 \mathrm{~Hz}, 1 \mathrm{H}), 5.90(\mathrm{~s}, 1 \mathrm{H}), 4.99-4.92(\mathrm{~m}, 1 \mathrm{H})$, $3.18(\mathrm{~s}, 3 \mathrm{H}), 2.70(\mathrm{~d}, J=4.2 \mathrm{~Hz}, 2 \mathrm{H}), 1.05-0.83(\mathrm{~m}, 2 \mathrm{H})$. Chiral SFC: $\mathrm{t}_{\mathrm{R}}=1.948 \mathrm{~min}, \mathrm{Lux}$ Cell- $3,10-50 \%$ methanol ( $0.1 \%$ ammonium hydroxide)-carbon dioxide.<smiles></smiles>

$(1 S, 2 S)-2-((S)-5 H$-imidazo[5,1-a]isoindol-5-yl)-6-(methylsulfonyl)-1,2,3,4tetrahydronaphthalen-1-ol (24). LCMS-ESI (m/z): $[\mathrm{M}+\mathrm{H}]^{+}$calcd for $\mathrm{C}_{21} \mathrm{H}_{21} \mathrm{~N}_{2} \mathrm{O}_{3} \mathrm{~S}, 381.1$; found 381.2. ${ }^{1} \mathrm{HNMR}\left(500 \mathrm{MHz}, \mathrm{CDCl}_{3}\right): \delta 7.92(\mathrm{~d}, J=8.2 \mathrm{~Hz}, 1 \mathrm{H}), 7.79(\mathrm{~d}, J=8.3 \mathrm{~Hz}, 1 \mathrm{H})$, $7.68(\mathrm{~s}, 1 \mathrm{H}), 7.54-7.62(\mathrm{~m}, 2 \mathrm{H}), 7.40(\mathrm{t}, J=7.5 \mathrm{~Hz}, 1 \mathrm{H}), 7.31(\operatorname{app} \mathrm{dd}, J=20.3,7.6 \mathrm{~Hz}, 2 \mathrm{H})$, $7.19(\mathrm{~s}, 1 \mathrm{H}), 5.86(\mathrm{~s}, 1 \mathrm{H}), 4.98(\mathrm{~d}, J=10.7 \mathrm{~Hz}, 1 \mathrm{H}), 3.04(\mathrm{~d}, \mathrm{~J}=2.0 \mathrm{~Hz}, 3 \mathrm{H}), 2.69-2.80(\mathrm{~m}$, $2 \mathrm{H}), 2.42(\mathrm{t}, J=11.6 \mathrm{~Hz}, 1 \mathrm{H}), 1.25(\mathrm{~d}, J=14.1 \mathrm{~Hz}, 1 \mathrm{H}), 1.04(\mathrm{dd}, J=12.4,6.9 \mathrm{~Hz}, 1 \mathrm{H})$. Chiral SFC: $t_{R}=1.160$ min, Chiralpak AS-3, 20\% methanol (0.1\% isopropylamine)-carbon dioxide.<smiles>CP(C)(=O)c1ccc2c(c1)C(O)C(C1c3ccccc3-c3cncn31)CC2</smiles>

((7S,8S)-8-hydroxy-7-((S)-5H-imidazo[5,1-a]isoindol-5-yl)-5,6,7,8-tetrahydronaphthalen-2yl)dimethylphosphine oxide (25). A suspension of 7-bromo-2-(5H-imidazo[5,1-a]isoindol-5yl)-1,2,3,4-tetrahydronaphthalen-1-ol (56k, $1.27 \mathrm{~g}, 3.3 \mathrm{mmol})$, dimethylphosphine oxide (516 $\mathrm{mg}, 6.5 \mathrm{mmol}$ ), palladium(II) acetate (163 $\mathrm{mg}, 0.73 \mathrm{mmol}$ ), 4,5-bis(diphenylphosphino)-9,9dimethylxanthene $(1.00 \mathrm{~g}, 1.7 \mathrm{mmol})$ and potassium phosphate $(2.32 \mathrm{~g}, 11 \mathrm{mmol})$ in $\mathrm{N}, \mathrm{N}$ dimethylformamide $(11 \mathrm{~mL})$ were heated in a microwave reactor at $140^{\circ} \mathrm{C}$ for $30 \mathrm{~min}$. The reaction mixture was diluted with dichloromethane $(100 \mathrm{~mL})$ and filtered. The solvent was removed under vacuum. The filtrate was suspended in ethyl acetate-dichloromethane $(1: 1,100$ $\mathrm{mL}$ ) and sonicated. The suspension was filtered. The filtrate was concentrated under vacuum. Purification by silica gel flash chromatography with $0-25 \%$ methanol-dichloromethane afforded the title compound $(1.1 \mathrm{~g}, 85 \%)$ as a mixture of diastereomers. LCMS-ESI $(\mathrm{m} / \mathrm{z}):[\mathrm{M}+\mathrm{H}]^{+}$calcd for $\mathrm{C}_{22} \mathrm{H}_{24} \mathrm{~N}_{2} \mathrm{O}_{2} \mathrm{P}, 379.2$; found 379.2. ${ }^{1} \mathrm{H}$ NMR (400 MHz, DMSO- $d_{6}$ ): $\delta 8.08$ (dd, $J=12.2,1.4$ 
$\mathrm{Hz}, 1 \mathrm{H}), 7.97(\mathrm{~s}, 1 \mathrm{H}), 7.64(\mathrm{dt}, J=7.6,0.9 \mathrm{~Hz}, 1 \mathrm{H}), 7.55-7.45(\mathrm{~m}, 2 \mathrm{H}), 7.41$ (tt, $J=7.5,0.9$ $\mathrm{Hz}, 1 \mathrm{H}), 7.31(\mathrm{td}, J=7.5,1.1 \mathrm{~Hz}, 1 \mathrm{H}), 7.18(\mathrm{~s}, 1 \mathrm{H}), 7.15(\mathrm{dd}, J=7.8,2.9 \mathrm{~Hz}, 1 \mathrm{H}), 6.14(\mathrm{~d}, J=$ $7.7 \mathrm{~Hz}, 1 \mathrm{H}), 5.84-5.78(\mathrm{~m}, 1 \mathrm{H}), 4.96(\mathrm{dd}, J=10.7,7.7 \mathrm{~Hz}, 1 \mathrm{H}), 2.65-2.56(\mathrm{~m}, 2 \mathrm{H}), 2.46-$ $2.36(\mathrm{~m}, 1 \mathrm{H}), 1.64(\mathrm{dd}, J=13.3,2.5 \mathrm{~Hz}, 6 \mathrm{H}), 0.98-0.75(\mathrm{~m}, 2 \mathrm{H})$. Chiral SFC: $\mathrm{t}_{\mathrm{R}}=0.790 \mathrm{~min}$, Chiralcel OX, $40 \%$ methanol ( $0.1 \%$ isopropylamine)-carbon dioxide.

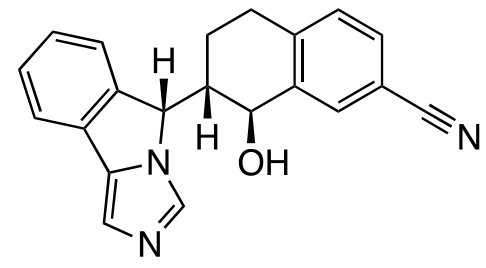

(7S,8S)-8-hydroxy-7-((S)-5H-imidazo[5,1-a] isoindol-5-yl)-5,6,7,8-tetrahydronaphthalene-2carbonitrile (26). $\mathrm{LCMS}-\mathrm{ESI}(\mathrm{m} / \mathrm{z})$ : $[\mathrm{M}+\mathrm{H}]^{+}$calcd for $\mathrm{C}_{21} \mathrm{H}_{18} \mathrm{~N}_{3} \mathrm{O}, 328.1$; found $328.1 .{ }^{1} \mathrm{H}$ NMR (400 MHz, DMSO- $\left.d_{6}\right): \delta 8.04-7.93(\mathrm{~m}, 2 \mathrm{H}), 7.69-7.56(\mathrm{~m}, 2 \mathrm{H}), 7.52-7.45(\mathrm{~m}, 1 \mathrm{H})$, 7.41 (ddd, $J=8.2,7.2,1.0 \mathrm{~Hz}, 1 \mathrm{H}), 7.31(\mathrm{td}, J=7.6,1.1 \mathrm{~Hz}, 1 \mathrm{H}), 7.23(\mathrm{~d}, J=8.0 \mathrm{~Hz}, 1 \mathrm{H}), 7.18$ (s, $1 \mathrm{H}), 6.30(\mathrm{~d}, J=7.4 \mathrm{~Hz}, 1 \mathrm{H}), 5.81(\mathrm{~d}, J=1.8 \mathrm{~Hz}, 1 \mathrm{H}), 4.95(\mathrm{dd}, J=10.6,7.3 \mathrm{~Hz}, 1 \mathrm{H}), 2.66$ (dd, $J=8.7,4.4 \mathrm{~Hz}, 2 \mathrm{H}), 2.45-2.31(\mathrm{~m}, 1 \mathrm{H}), 0.98-0.90(\mathrm{~m}, 1 \mathrm{H}), 0.85(\mathrm{dd}, J=8.1,3.9 \mathrm{~Hz}$, $1 \mathrm{H})$. Chiral SFC: $\mathrm{t}_{\mathrm{R}}=1.530 \mathrm{~min}$, Chiralpak OX-H, $50 \%$ methanol (0.1\% isopropylamine)carbon dioxide.

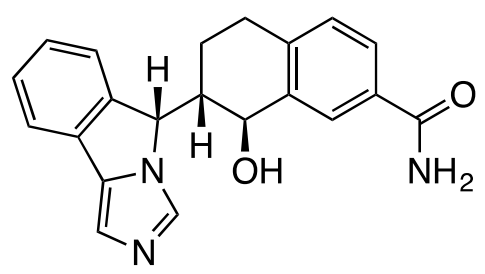

(7S,8S)-8-hydroxy-7-((S)-5H-imidazo[5,1-a] isoindol-5-yl)-5,6,7,8-tetrahydronaphthalene-2carboxamide (27). LCMS-ESI (m/z): $[\mathrm{M}+\mathrm{H}]^{+}$calcd for $\mathrm{C}_{21} \mathrm{H}_{20} \mathrm{~N}_{3} \mathrm{O}_{2}, 346.2$; found $346.1 .{ }^{1} \mathrm{H}$ NMR (400 MHz, DMSO- $\left.d_{6}\right): \delta 8.22(\mathrm{dd}, J=1.9,0.9 \mathrm{~Hz}, 1 \mathrm{H}), 7.95(\mathrm{t}, J=0.6 \mathrm{~Hz}, 1 \mathrm{H}), 7.90(\mathrm{~s}$, $1 \mathrm{H}), 7.69-7.61(\mathrm{~m}, 2 \mathrm{H}), 7.48(\mathrm{dq}, J=7.6,0.9 \mathrm{~Hz}, 1 \mathrm{H}), 7.46-7.37(\mathrm{~m}, 1 \mathrm{H}), 7.31(\mathrm{td}, J=7.5$, $1.1 \mathrm{~Hz}, 1 \mathrm{H}), 7.24(\mathrm{~s}, 1 \mathrm{H}), 7.18(\mathrm{~s}, 1 \mathrm{H}), 7.06(\mathrm{~d}, J=7.9 \mathrm{~Hz}, 1 \mathrm{H}), 6.06(\mathrm{~d}, J=7.8 \mathrm{~Hz}, 1 \mathrm{H}), 5.83(\mathrm{~d}$, $J=1.9 \mathrm{~Hz}, 1 \mathrm{H}), 5.04-4.85(\mathrm{~m}, 1 \mathrm{H}), 3.51-3.39(\mathrm{~m}, 1 \mathrm{H}), 2.65-2.56(\mathrm{~m}, 2 \mathrm{H}), 2.45-2.32(\mathrm{~m}$, $1 \mathrm{H}), 1.30-1.19(\mathrm{~m}, 1 \mathrm{H})$. Chiral SFC: $\mathrm{t}_{\mathrm{R}}=0.8491 \mathrm{~min}$, Chiralpak OX-H, $40 \%$ methanol $(0.1 \%$ isopropylamine)-carbon dioxide.

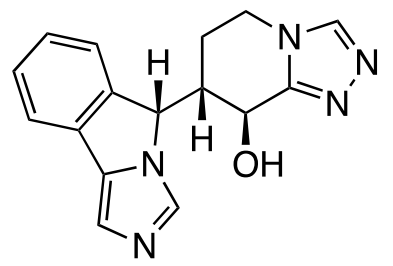

(7S,8S)-7-((S)-5H-imidazo[5,1-a]isoindol-5-yl)-5,6,7,8-tetrahydro-[1,2,4]triazolo[4,3a]pyridin-8-ol (28). LCMS-ESI (m/z): [M+H] ${ }^{+}$calcd for $\mathrm{C}_{16} \mathrm{H}_{16} \mathrm{~N}_{5} \mathrm{O}, 394.1$; found $294.1 .{ }^{1} \mathrm{H}$ NMR (300 MHz, CD $\left.{ }_{3} \mathrm{OD}\right): \delta 8.41(\mathrm{~s}, 1 \mathrm{H}), 8.13(\mathrm{~s}, 1 \mathrm{H}), 7.69-7.56(\mathrm{~m}, 2 \mathrm{H}), 7.50-7.29(\mathrm{~m}$, 2H), $7.17(\mathrm{~s}, 1 \mathrm{H}), 5.68(\mathrm{~s}, 1 \mathrm{H}), 5.47(\mathrm{~d}, J=3.5 \mathrm{~Hz}, 1 \mathrm{H}), 4.25-4.12(\mathrm{~m}, 1 \mathrm{H}), 3.79-3.61(\mathrm{~m}$, $1 \mathrm{H}), 2.88-2.75(\mathrm{~m}, 1 \mathrm{H}), 1.95-1.89(\mathrm{~m}, 1 \mathrm{H}), 1.24(\mathrm{~d}, J=13.9 \mathrm{~Hz}, 1 \mathrm{H})$. Chiral HPLC: $\mathrm{t}_{\mathrm{R}}=$ $3.827 \mathrm{~min}$, Chiralpak AD-H, $50 \%$ hexanes $(0.1 \%$ diethanolamine $)$-ethanol. 


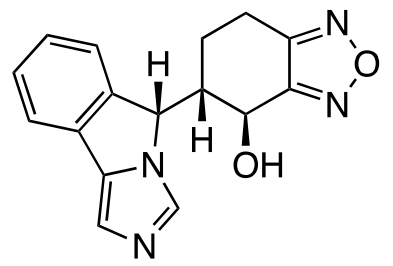

(4S,5S)-5-((S)-5H-imidazo[5,1-a] isoindol-5-yl)-4,5,6,7-tetrahydrobenzo[c][1,2,5]oxadiazol-4ol (29). LCMS-ESI (m/z): $[\mathrm{M}+\mathrm{H}]^{+}$calcd for $\mathrm{C}_{16} \mathrm{H}_{15} \mathrm{~N}_{4} \mathrm{O}_{2}$, 295.1; found 295.4. ${ }^{1} \mathrm{HNMR}(500$ MHz, DMSO- $\left.d_{6}\right): \delta 7.99(\mathrm{~s}, 1 \mathrm{H}), 7.64(\mathrm{dt}, J=7.7,1.0 \mathrm{~Hz}, 1 \mathrm{H}), 7.52-7.46(\mathrm{~m}, 1 \mathrm{H}), 7.43(\mathrm{tt}, J=$ 7.6, $0.9 \mathrm{~Hz}, 1 \mathrm{H}), 7.33(\mathrm{td}, J=7.6,1.1 \mathrm{~Hz}, 1 \mathrm{H}), 7.19(\mathrm{~s}, 1 \mathrm{H}), 6.69(\mathrm{~d}, J=7.2 \mathrm{~Hz}, 1 \mathrm{H}), 5.80-5.71$ $(\mathrm{m}, 1 \mathrm{H}), 5.26(\mathrm{dd}, J=11.0,7.3 \mathrm{~Hz}, 1 \mathrm{H}), 2.78(\mathrm{dt}, J=17.3,3.8 \mathrm{~Hz}, 1 \mathrm{H}), 2.65-2.53(\mathrm{~m}, 2 \mathrm{H})$, $0.96(\mathrm{dtd}, J=11.2,6.4,3.9 \mathrm{~Hz}, 2 \mathrm{H})$. Chiral SFC: $\mathrm{t}_{\mathrm{R}}=0.990 \mathrm{~min}$, Chiralpak OX-H, $45 \%$ ethanol ( $0.1 \%$ isopropylamine)-carbon dioxide.

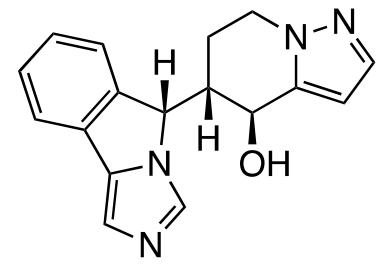

(4S,5S)-5-((S)-5H-imidazo[5,1-a]isoindol-5-yl)-4,5,6,7-tetrahydropyrazolo[1,5-a]pyridin-4ol (30). LCMS-ESI (m/z): $[\mathrm{M}+\mathrm{H}]^{+}$calcd for $\mathrm{C}_{17} \mathrm{H}_{17} \mathrm{~N}_{4} \mathrm{O}$, 293.1; found 293.5. ${ }^{1} \mathrm{HNMR}$ (500 MHz, DMSO- $\left.d_{6}\right): \delta 7.98(\mathrm{~s}, 1 \mathrm{H}), 7.64(\mathrm{dt}, J=7.6,0.9 \mathrm{~Hz}, 1 \mathrm{H}), 7.51(\mathrm{dd}, J=7.6,1.0 \mathrm{~Hz}, 1 \mathrm{H})$, $7.46-7.38(\mathrm{~m}, 2 \mathrm{H}), 7.34(\mathrm{dd}, J=7.5,1.1 \mathrm{~Hz}, 1 \mathrm{H}), 7.19(\mathrm{~s}, 1 \mathrm{H}), 6.31(\mathrm{dd}, J=1.9,0.8 \mathrm{~Hz}, 1 \mathrm{H})$, $6.18(\mathrm{~d}, J=7.2 \mathrm{~Hz}, 1 \mathrm{H}), 5.76(\mathrm{~d}, J=1.9 \mathrm{~Hz}, 1 \mathrm{H}), 5.03(\mathrm{dd}, J=10.5,7.2 \mathrm{~Hz}, 1 \mathrm{H}), 4.01-3.93$ $(\mathrm{m}, 1 \mathrm{H}), 3.84-3.73(\mathrm{~m}, 1 \mathrm{H}), 2.59-2.51(\mathrm{~m}, 1 \mathrm{H}), 1.16-1.01(\mathrm{~m}, 2 \mathrm{H}) . \mathrm{SFC}: \mathrm{t}_{\mathrm{R}}=1.238 \mathrm{~min}$, Chiralpak OX-H, 30\% methanol (0.1\% isopropylamine)-carbon dioxide.

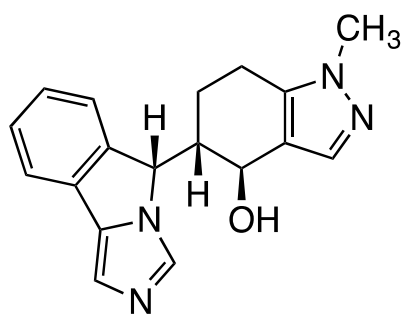

(4S,5S)-5-((S)-5H-imidazo[5,1-a] isoindol-5-yl)-1-methyl-4,5,6,7-tetrahydro-1 $H$-indazol-4-ol (31). LCMS-ESI (m/z): $[\mathrm{M}+\mathrm{H}]^{+}$calcd for $\mathrm{C}_{18} \mathrm{H}_{19} \mathrm{~N}_{4} \mathrm{O}, 307.2$; found 307.1. ${ }^{1} \mathrm{HNMR}(500 \mathrm{MHz}$, DMSO- $\left.d_{6}\right): \delta 7.92(\mathrm{~s}, 1 \mathrm{H}), 7.63(\mathrm{~d}, J=7.5 \mathrm{~Hz}, 1 \mathrm{H}), 7.45(\mathrm{~d}, J=7.6 \mathrm{~Hz}, 1 \mathrm{H}), 7.43-7.29(\mathrm{~m}$, $3 \mathrm{H}), 7.17(\mathrm{~s}, 1 \mathrm{H}), 5.76(\mathrm{~s}, 1 \mathrm{H}), 5.62(\mathrm{~d}, J=7.1 \mathrm{~Hz}, 1 \mathrm{H}), 4.92(\mathrm{~d}, J=8.0 \mathrm{~Hz}, 1 \mathrm{H}), 3.58(\mathrm{~s}, 3 \mathrm{H})$, 2.44 (dd, $J=16.2,5.4 \mathrm{~Hz}, 1 \mathrm{H}), 2.36-2.25(\mathrm{~m}, 1 \mathrm{H}), 2.20(\mathrm{td}, J=11.9,2.5 \mathrm{~Hz}, 1 \mathrm{H}), 0.96-0.79$ $(\mathrm{m}, 2 \mathrm{H}) . \mathrm{SFC}: \mathrm{t}_{\mathrm{R}}=1.345 \mathrm{~min}$, Chiralpak OX-H, $45 \%$ methanol ( $0.1 \%$ isopropylamine)-carbon dioxide. 


\section{Pharmacological Assays}

\section{TDO (1.13.11.11) Biochemical Assay}

Test compound is added to duplicate wells of a 384 well v-bottom polypropylene microplate (Greiner) as $100 \mathrm{~nL}$ of DMSO solution for a final concentration of $3 \mathrm{nM}$ to $25 \mu \mathrm{M}$ in the enzyme reaction. $10 \mu \mathrm{L}$ human recombinant TDO enzyme (NTRC) is added at $50 \mathrm{nM}$ in assay buffer ( $50 \mathrm{mM}$ sodium phosphate $\mathrm{pH} 7.0,0.01 \%$ Tween-20) with $2 \mathrm{mM}$ tris(2-carboxyethyl)phosphine (TCEP, Sigma) and $100 \mu \mathrm{M}$ sodium-L-ascorbate (Sigma). Enzyme is not added to low control wells. After 5 minutes pre-incubation at ambient temperature, the reaction is initiated by the addition of $10 \mu \mathrm{L}$ L-tryptophan (Calbiochem) at $400 \mu \mathrm{M}$ in assay buffer. The final tryptophan concentration of $200 \mu \mathrm{M}$ is slightly higher than the apparent hTDO $\mathrm{K}_{\mathrm{m}}$ for tryptophan measured as $160 \mu \mathrm{M}$. After 15 minutes reaction at ambient temperature, the reaction is stopped by a $20 \mu \mathrm{L}$ addition of $1 \%$ formic acid (Thermo). $60 \mu \mathrm{L} 0.1 \%$ formic acid (Burdick and Jackson) is added to dilute the reaction mixture. Tryptophan and NFK concentrations are measured using a RapidFire (Biocius) coupled to an ABSciex 5500 QTrap mass spectrometer. Briefly, samples are loaded onto a phenyl cartridge (Agilent) and eluted with $0.1 \%$ formic acid in $80 \%$ acetonitrile followed by ionization, $\mathrm{m} / \mathrm{z}$ selection, and identification by fragmentation. Analyst and RapidFire Integrator software (Biocius) are used to identify substrate and product peaks and calculate area under the curve (AUC). The normalized ratio of AUCNFK divided by (AUCtryptophan + AUCNFK) is calculated for each well to minimize the effect of injection variability. Signal is further normalized to $\%$ inhibition relative to DMSO treatment as $0 \%$ inhibition and low control wells as $100 \%$ inhibition. $\mathrm{IC}_{50}$ values are determined using a fourparameter fit of percent inhibition versus compound concentration using Genedata Analyst software (Genedata).

\section{IDO and TDO Cell Assays}

The NFK GreenScreen ${ }^{\mathrm{TM}}$ (NTRC, Netherlands) uses a specific chemical probe that binds to $\mathrm{N}$ Formylkynurenine (NFK), a product of tryptophan catabolism facilitated by IDO1 or TDO and causes fluorescence at $510 \mathrm{~nm}$ when excited at $410 \mathrm{~nm}$. The assay is used to assess compound inhibition of TDO and IDO1 leading to decreased levels of NFK in SW48 cells (high TDO expressing cells) and to determine whether compounds are selective against A172+IFN $\gamma$ cells (high IDO expressing cells) or are dual inhibitors in cells. The assay is multiplexed with Cell Titer-Glo ${ }^{\circledR}$ (Promega) to determine if compounds are cytotoxic. Briefly, SW48 or A172 cells are harvested in growth media, RPMI 1640 with $10 \%$ FBS, $2 \mathrm{mM} \mathrm{L}$-glutamine, and $1 \times$ pen/strep. Cells are re-suspended in assay media, tryptophan-free RPMI 1640 supplemented with $2 \%$ dialyzed FBS, $2 \mathrm{mM}$ L-glutamine, and $1 \times$ pen/strep. Cells are counted on a Vi-Cell (Beckman Coulter). SW48 cells are diluted to $1 \times 10^{6}$ cells $/ \mathrm{ml}$ in assay media. A172 cells are diluted to $0.24 \times 10^{6}$ cells $/ \mathrm{mL}$ in assay media. $25 \mu \mathrm{L}$ of cells are dispensed with a Multi-Flo (Bio-Tek) dispenser to a 384 well greiner $\mu$ clear plate (Greiner, 781091) with 14 compounds in duplicate. Compounds are dispensed into plates with an Echo ${ }^{\circledR}$ (Labcyte) starting at the highest concentration of $25 \mu \mathrm{M}$ and are diluted approximately $3 \times$ in a 10-point titration. $5 \mu \mathrm{L}$ of assay media containing $1.2 \mathrm{mM}$ tryptophan are added to the SW48 cells for a final concentration of $200 \mu \mathrm{M}$ tryptophan in each well. $5 \mu \mathrm{L}$ of assay media containing $600 \mu \mathrm{M}$ tryptophan and 600 
$\mathrm{ng} / \mathrm{mL}$ IFN $\gamma$ are added to the A172 cells for a final concentration of $100 \mu \mathrm{M}$ tryptophan and 100 $\mathrm{ng} / \mathrm{mL}$ IFN $\gamma$ in each well. The final DMSO concentration is $0.5 \%$. Cell plates are placed at room temperature in a closed TC hood with the blower off to allow cells to settle for approximately $30 \mathrm{~min}$. Plates are then moved to an incubator set at $37{ }^{\circ} \mathrm{C}, 5 \% \mathrm{CO}_{2}$ for 24 hours. After the 24 hour compound incubation, $8 \mu \mathrm{L}$ of NFK green reagent is added to each well with a Multidrop ${ }^{\mathrm{TM}}$ Combi dispenser (Thermo Scientific). Plates are sealed and incubated at $37{ }^{\circ} \mathrm{C}, 5 \%$ $\mathrm{CO}_{2}$ for 5 hours, then read on a PHERAstar ${ }^{(B M G}$ labtech). Data are analyzed by normalizing to DMSO and high inhibitor controls. After the plates have been read for NFK green, $25 \mu \mathrm{L}$ of Cell Titer-Glo ${ }^{\circledR}$ (Promega) are added to each well, incubated for 15 minutes at room temperature, and read on the Envision (Perkin Elmer). Cell Titer-Glo data are analyzed by normalizing to the DMSO controls. Four parameter curve fitting is used and $\mathrm{EC}_{50}$ data are reported to the database. 


\section{TDO2 Expression, Purification and Crystallization}

C-terminal FLAG-tagged TDO2 L18-F388 was expressed in insect cells in the presence of $4 \mathrm{uM}$ hemin and $0.4 \mathrm{mM} 5$-aminolevulinic acid (5-ALA). After the first 4 hours of infection, $100 \mathrm{uM}$ tryptophan was added. The cells were harvested then lysed in a buffer of $50 \mathrm{mM}$ HEPES pH 7.5, 1.0 M sodium chloride, $10 \mathrm{mM}$ tryptophan, $200 \mathrm{ug} / \mathrm{mL}$ sodium nitroprusside (SNP), 5\% glycerol, $50 \mathrm{uM}$ E-64 protease inhibitor, $0.5 \mathrm{ug} / \mathrm{mL}$ leupeptin, $1 \mathrm{mM}$ phenylmethane sulfonyl fluoride (PMSF) and Calbiochem protease inhibitor cocktail set III, EDTA-free. The protein was purified using equilibrated anti-FLAG M2 affinity agarose gel (Sigma) by gravity flow and then eluted with $150 \mathrm{ug} / \mathrm{mL}$ FLAG peptide. The pooled FLAG-tagged protein was concentrated and purified over an equilibrated S75 16/60 gel filtration column in a buffer of $20 \mathrm{mM}$ HEPES pH 7.5, 1.0M sodium chloride, 5\% glycerol, $200 \mathrm{uM}$ tryptophan, $200 \mathrm{ug} / \mathrm{mL} \mathrm{SNP.} \mathrm{The} \mathrm{BCA} \mathrm{assay}$ was used to measure TDO2 protein concentration. The protein was concentrated to $20 \mathrm{mg} / \mathrm{mL}$ and flash frozen in liquid nitrogen. Heme incorporation was determined by measuring the ratio of A406/A280, with a value of 2.2 representing $100 \%$ heme incorporation. ${ }^{7}$ TDO2 protein samples purified for crystallography were measured to have a 406:280 ratio of 1.1 or above. TDO2 samples were also measured via ICP-MS and confirmed to have $>67 \%$ heme incorporation.

After adding $1 \mathrm{mM}$ of the compound to the TDO2-heme protein, single crystals of TDO2-heme were grown in a 1:1 ratio of protein:well solution of $100 \mathrm{mM}$ MES, $\mathrm{pH} 6.0,16 \%-19 \%$ PEG $6000,0.2 \mathrm{M}$ calcium chloride and 3\% ethylene glycol. Red rod-shaped crystals appeared about 6 days after setup at $4^{\circ} \mathrm{C}$. The crystals were then harvested in a cryo-protectant solution of $8 \%-10 \%$ ethylene glycol and 2\% sucrose, flash frozen in liquid nitrogen for data collection.

Data were collected at the Stanford Synchrotron Radiation Lightsource (SSRL) beamline 12-2. The structure was determined by molecular replacement using PHASER ${ }^{8}$ and search model 4PW8, subsequently refined with iterative cycles of manual model building $\left(\mathrm{COOT}^{9}\right)$ and refinement (BUSTER ${ }^{10}$ ). The final statistics on data reduction and refinement are shown in supplemental Table X. Coordinates and structure factors are deposited under accession code 6VBN.

Table S3. Data collection and refinement statistics.

\begin{tabular}{|c|c|}
\hline & 6VBN \\
\hline Wavelength & 0.9795 \\
\hline Resolution range & $39.27-3.18(3.294-3.18)$ \\
\hline Space group & P 212121 \\
\hline Unit cell & 78.475143 .044147 .236909090 \\
\hline Total reflections & $376599(38816)$ \\
\hline Unique reflections & $28519(2802)$ \\
\hline Multiplicity & $13.2(13.9)$ \\
\hline Completeness (\%) & $99.71(99.82)$ \\
\hline Mean I/sigma(I) & $17.58(2.22)$ \\
\hline
\end{tabular}


Wilson B-factor

R-merge

R-meas

R-pim

$\mathrm{CC} 1 / 2$

CC*

Reflections used in

refinement

Reflections used for $\mathbf{R}$-free

R-work

R-free

CC(work)

$\mathrm{CC}($ free)

Number of non-hydrogen

atoms

macromolecules

ligands

solvent

Protein residues

RMS(bonds)

RMS(angles)

Ramachandran favored (\%)

Ramachandran allowed (\%)

Ramachandran outliers (\%)

Rotamer outliers (\%)

Clashscore

Average B-factor

macromolecules

ligands

solvent
93.23

$0.1371(1.634)$

0.1427 (1.696)

$0.0391(0.4499)$

$0.999(0.82)$

$1(0.949)$

28510 (2801)

$1383(150)$

$0.2102(0.3188)$

$0.2496(0.3704)$

$0.958(0.806)$

$0.963(0.799)$

11873

11589

248

36

1375

0.014

1.62

95.98

3.66

0.37

4.66

2.56

110.85

111.01

108.83

71.34

Statistics for the highest-resolution shell are shown in parentheses 


\section{Small Molecule X-ray Crystallography}

\section{Experimental data for SC-XRD on Compound 7}

$\mathrm{X}$-ray quality crystals were grown from a saturated toluene/ethanol/methanol solution followed by the slow vapor diffusion of diisopropyl ether to deposit the crystal diffracted. A colorless rod $0.050 \times 0.020 \times 0.020 \mathrm{~mm}$ in size was mounted on a Cryoloop with Paratone oil. Data were collected in a nitrogen gas stream at $100(2) \mathrm{K}$ using phi and omega scans. Crystal-to-detector distance was $60 \mathrm{~mm}$ and exposure time was 10 seconds per frame using a scan width of $2.0^{\circ}$. Data collection was $100.0 \%$ complete to $67.000^{\circ}$ in theta. A total of 44320 reflections were collected covering the indices, $-19<=h<=19,-5<=k<=5,-23<=l<=22.5518$ reflections were found to be symmetry independent, with an $\mathrm{R}_{\text {int }}$ of 0.0513 . Indexing and unit cell refinement indicated a primitive, monoclinic lattice. The space group was found to be P 21 (No. 4). The data were integrated using the Bruker SAINT software program and scaled using the SADABS software program. Solution by iterative methods (SHELXT) produced a complete heavy-atom phasing model consistent with the proposed structure. All non-hydrogen atoms were refined anisotropically by full-matrix least-squares (SHELXL-2014). All hydrogen atoms were placed using a riding model. Their positions were constrained relative to their parent atom using the appropriate HFIX command in SHELXL-2014. Absolute stereochemistry was unambiguously determined to be $S$ at $\mathrm{C} 1, \mathrm{C} 12, \mathrm{C} 19$, and $\mathrm{C} 30$, respectively. 
Table 1. Crystal data and structure refinement for Compound 7.

X-ray ID Compound 7

Sample/notebook ID Compound 7

Empirical formula C18 H22 N2 O

Formula weight $\quad 282.37$

Temperature $100(2) \mathrm{K}$

Wavelength $1.54178 \AA$

Crystal system Monoclinic

Space group P 21

Unit cell dimensions $\mathrm{a}=16.3071(3) \AA \quad$ alpha $=90^{\circ}$. $\mathrm{b}=4.73520(10) \AA \quad$ beta $=97.8660(10)^{\circ}$. $\mathrm{c}=19.7305(4) \AA \quad$ gamma $=90^{\circ}$.

Volume $\quad 1509.20(5) \AA 3$

Z 4

Density (calculated) $\quad 1.243 \mathrm{Mg} / \mathrm{m} 3$

Absorption coefficient $\quad 0.605 \mathrm{~mm}-1$

$\mathrm{F}(000) 608$

Crystal size $\quad 0.050 \times 0.020 \times 0.020 \mathrm{~mm} 3$

Theta range for data collection 2.260 to $68.425^{\circ}$.

Index ranges $-19<=\mathrm{h}<=19,-5<=\mathrm{k}<=5,-23<=1<=22$

Reflections collected 44320

Independent reflections $\quad 5518$ [R(int) $=0.0513]$

Completeness to theta $=67.000^{\circ} \quad 100.0 \%$

Absorption correction Semi-empirical from equivalents

Max. and min. transmission 0.929 and 0.815

Refinement method Full-matrix least-squares on F2

Data / restraints / parameters 5518/1/381

Goodness-of-fit on F2 1.048

Final $\mathrm{R}$ indices $[\mathrm{I}>2 \operatorname{sigma}(\mathrm{I})] \mathrm{R} 1=0.0299, \mathrm{wR} 2=0.0738$

$\mathrm{R}$ indices (all data) $\quad \mathrm{R} 1=0.0323, \mathrm{wR} 2=0.0753$

Absolute structure parameter 0.00(9)

Extinction coefficient $\mathrm{n} / \mathrm{a}$

Largest diff. peak and hole $\quad 0.164$ and -0.165 e. $\AA-3$ 
Table 2. Atomic coordinates ( $\mathrm{x} 104)$ and equivalent isotropic displacement parameters ( $\AA 2 \mathrm{x}$ 103)

for Compound 7. $\mathrm{U}(\mathrm{eq})$ is defined as one third of the trace of the orthogonalized Uij tensor.

\begin{tabular}{|c|c|c|c|c|}
\hline- & $\mathrm{X}$ & $\mathrm{U}(\mathrm{eq})$ & & \\
\hline$\overline{\mathrm{C}}(1)$ & $7535(1)$ & $9506(4)$ & $9157(1)$ & $20(1)$ \\
\hline$C(2)$ & $8077(1)$ & $8628(4)$ & $9814(1)$ & 21(1) \\
\hline$C(3)$ & $8016(1)$ & $9489(5)$ & $10477(1)$ & $26(1)$ \\
\hline$C(4)$ & $8553(1)$ & $8307(5)$ & $11008(1)$ & $29(1)$ \\
\hline$C(5)$ & $9128(1)$ & $6275(5)$ & $10882(1)$ & $27(1)$ \\
\hline$C(6)$ & $9197(1)$ & $5428(5)$ & $10219(1)$ & $25(1)$ \\
\hline$C(7)$ & $8671(1)$ & $6645(5)$ & $9683(1)$ & 21(1) \\
\hline $\mathrm{C}(8)$ & $8599(1)$ & $6286(4)$ & 8943(1) & 21(1) \\
\hline $\mathrm{C}(9)$ & 8922(1) & $5085(5)$ & $8406(1)$ & $25(1)$ \\
\hline$C(10)$ & $7910(1)$ & $7729(4)$ & $7970(1)$ & $22(1)$ \\
\hline $\mathrm{C}(11)$ & $6632(1)$ & $8638(4)$ & $9164(1)$ & $21(1)$ \\
\hline$C(12)$ & $6061(1)$ & $9229(4)$ & $8502(1)$ & $19(1)$ \\
\hline$C(13)$ & $5151(1)$ & $8499(4)$ & $8560(1)$ & $20(1)$ \\
\hline$C(14)$ & $4809(1)$ & $9916(5)$ & $9159(1)$ & $24(1)$ \\
\hline$C(15)$ & $3904(1)$ & $9099(5)$ & $9179(1)$ & $28(1)$ \\
\hline$C(16)$ & $3359(1)$ & $9828(5)$ & $8510(1)$ & $29(1)$ \\
\hline$C(17)$ & $3689(1)$ & $8450(5)$ & $7908(1)$ & $29(1)$ \\
\hline $\mathrm{C}(18)$ & $4598(1)$ & $9209(5)$ & $7888(1)$ & $25(1)$ \\
\hline$C(19)$ & $7428(1)$ & 2719(4) & $5467(1)$ & $18(1)$ \\
\hline$C(20)$ & $6936(1)$ & $1229(4)$ & 4861(1) & $19(1)$ \\
\hline $\mathrm{C}(21)$ & $7063(1)$ & $1278(5)$ & $4183(1)$ & $24(1)$ \\
\hline $\mathrm{C}(22)$ & $6554(1)$ & $-364(5) 3713(1)$ & ) $\quad 27(1)$ & \\
\hline $\mathrm{C}(23)$ & $5930(1)$ & $-2014(5)$ & $3921(1)$ & $29(1)$ \\
\hline $\mathrm{C}(24)$ & $5801(1)$ & $-2091(5)$ & $4602(1)$ & $25(1)$ \\
\hline$C(25)$ & $6307(1)$ & $-450(4) 5070(1)$ & ) $20(1)$ & \\
\hline$C(26)$ & $6319(1)$ & $-8(4) \quad 5802(1)$ & $20(1)$ & \\
\hline $\mathrm{C}(27)$ & $5943(1)$ & $-547(5) 6370(1)$ & ) $23(1)$ & \\
\hline $\mathrm{C}(28)$ & $6900(1)$ & $2548(5)$ & $6670(1)$ & $22(1)$ \\
\hline C(29) & $8318(1)$ & $1593(4)$ & $5602(1)$ & $19(1)$ \\
\hline$C(30)$ & $8784(1)$ & $2305(4)$ & $6301(1)$ & $18(1)$ \\
\hline$C(31)$ & $9683(1)$ & $1286(4)$ & $6373(1)$ & $18(1)$ \\
\hline$C(32)$ & $10223(1)$ & $2829(4)$ & $5912(1)$ & $20(1)$ \\
\hline$C(33)$ & $11097(1)$ & $1604(5)$ & $5990(1)$ & $25(1)$ \\
\hline $\mathrm{C}(34)$ & $11506(1)$ & $1669(5)$ & $6735(1)$ & $26(1)$ \\
\hline$C(35)$ & 10971(1) & $164(5) 7197(1$ & ) $25(1)$ & \\
\hline$C(36)$ & $10097(1)$ & $1395(4)$ & $7119(1)$ & $21(1)$ \\
\hline $\mathrm{N}(1)$ & $8488(1)$ & $6013(4)$ & 7799(1) & $25(1)$ \\
\hline $\mathrm{N}(2)$ & $7951(1)$ & $7937(4)$ & $8653(1)$ & $19(1)$ \\
\hline
\end{tabular}


$\mathrm{N}(3) \quad 6307(1) \quad 1083(4) \quad 6909(1) \quad 23(1)$

$\mathrm{N}(4) \quad 6931(1) \quad 1937(4) \quad 6010(1) \quad 19(1)$

$\begin{array}{llll}\mathrm{O}(1) & 6163(1) & 12098(3) & 8313(1)\end{array}$

$\mathrm{O}(2) \quad 8718(1) \quad 5268(3) \quad 6415(1) \quad 19(1)$ 
Table 3. Bond lengths $[\AA]$ and angles $\left[^{\circ}\right]$ for Compound 7 .

\begin{tabular}{|c|c|c|c|}
\hline $\mathrm{C}(1)-\mathrm{N}(2)$ & $1.479(2)$ & $\mathrm{C}(18)-\mathrm{H}(18 \mathrm{~B})$ & 0.9900 \\
\hline$C(1)-C(2)$ & $1.523(3)$ & $\mathrm{C}(19)-\mathrm{N}(4)$ & $1.476(2)$ \\
\hline $\mathrm{C}(1)-\mathrm{C}(11)$ & $1.530(3)$ & $C(19)-C(20)$ & $1.519(3)$ \\
\hline $\mathrm{C}(1)-\mathrm{H}(1)$ & 1.0000 & $C(19)-C(29)$ & $1.535(2)$ \\
\hline $\mathrm{C}(2)-\mathrm{C}(3)$ & $1.386(3)$ & $\mathrm{C}(19)-\mathrm{H}(19)$ & 1.0000 \\
\hline $\mathrm{C}(2)-\mathrm{C}(7)$ & $1.399(3)$ & $\mathrm{C}(20)-\mathrm{C}(21)$ & $1.382(3)$ \\
\hline$C(3)-C(4)$ & $1.388(3)$ & $C(20)-C(25)$ & $1.403(3)$ \\
\hline $\mathrm{C}(3)-\mathrm{H}(3)$ & 0.9500 & $\mathrm{C}(21)-\mathrm{C}(22)$ & $1.393(3)$ \\
\hline $\mathrm{C}(4)-\mathrm{C}(5)$ & $1.389(3)$ & $\mathrm{C}(21)-\mathrm{H}(21)$ & 0.9500 \\
\hline $\mathrm{C}(4)-\mathrm{H}(4)$ & 0.9500 & $\mathrm{C}(22)-\mathrm{C}(23)$ & $1.387(3)$ \\
\hline$C(5)-C(6)$ & $1.387(3)$ & $\mathrm{C}(22)-\mathrm{H}(22)$ & 0.9500 \\
\hline $\mathrm{C}(5)-\mathrm{H}(5)$ & 0.9500 & $C(23)-C(24)$ & $1.390(3)$ \\
\hline$C(6)-C(7)$ & $1.392(3)$ & $\mathrm{C}(23)-\mathrm{H}(23)$ & 0.9500 \\
\hline $\mathrm{C}(6)-\mathrm{H}(6)$ & 0.9500 & $C(24)-C(25)$ & $1.389(3)$ \\
\hline $\mathrm{C}(7)-\mathrm{C}(8)$ & $1.459(3)$ & $\mathrm{C}(24)-\mathrm{H}(24)$ & 0.9500 \\
\hline $\mathrm{C}(8)-\mathrm{C}(9)$ & $1.370(3)$ & $C(25)-C(26)$ & $1.458(3)$ \\
\hline $\mathrm{C}(8)-\mathrm{N}(2)$ & $1.374(2)$ & $C(26)-C(27)$ & $1.373(3)$ \\
\hline $\mathrm{C}(9)-\mathrm{N}(1)$ & $1.378(3)$ & $\mathrm{C}(26)-\mathrm{N}(4)$ & $1.378(3)$ \\
\hline $\mathrm{C}(9)-\mathrm{H}(9)$ & 0.9500 & $\mathrm{C}(27)-\mathrm{N}(3)$ & 1.381(3) \\
\hline $\mathrm{C}(10)-\mathrm{N}(1)$ & $1.323(3)$ & $\mathrm{C}(27)-\mathrm{H}(27)$ & 0.9500 \\
\hline $\mathrm{C}(10)-\mathrm{N}(2)$ & $1.344(2)$ & $\mathrm{C}(28)-\mathrm{N}(3)$ & $1.327(3)$ \\
\hline $\mathrm{C}(10)-\mathrm{H}(10)$ & 0.9500 & $\mathrm{C}(28)-\mathrm{N}(4)$ & $1.341(2)$ \\
\hline $\mathrm{C}(11)-\mathrm{C}(12)$ & $1.523(3)$ & $\mathrm{C}(28)-\mathrm{H}(28)$ & 0.9500 \\
\hline $\mathrm{C}(11)-\mathrm{H}(11 \mathrm{~A})$ & 0.9900 & $\mathrm{C}(29)-\mathrm{C}(30)$ & $1.520(2)$ \\
\hline \multicolumn{2}{|c|}{$\mathrm{C}(11)-\mathrm{H}(11 \mathrm{~B}) 0.9900$} & $\mathrm{C}(29)-\mathrm{H}(29 \mathrm{~A})$ & \multirow{2}{*}{0.99000 .9900} \\
\hline $\mathrm{C}(12)-\mathrm{O}(1)$ & $1.425(2)$ & $\mathrm{C}(29)-\mathrm{H}(29 \mathrm{~B}) 0.9900$ & \\
\hline $\mathrm{C}(12)-\mathrm{C}(13)$ & $1.542(3)$ & $\mathrm{C}(30)-\mathrm{O}(2)$ & $1.427(2)$ \\
\hline $\mathrm{C}(12)-\mathrm{H}(12)$ & 1.0000 & $\mathrm{C}(30)-\mathrm{C}(31)$ & $1.531(2)$ \\
\hline$C(13)-C(14)$ & $1.531(3)$ & $\mathrm{C}(30)-\mathrm{H}(30)$ & 1.0000 \\
\hline $\mathrm{C}(13)-\mathrm{C}(18)$ & $1.535(3)$ & $\mathrm{C}(31)-\mathrm{C}(32)$ & $1.534(2)$ \\
\hline $\mathrm{C}(13)-\mathrm{H}(13)$ & 1.0000 & $C(31)-C(36)$ & $1.535(2)$ \\
\hline$C(14)-C(15)$ & $1.531(3)$ & $\mathrm{C}(31)-\mathrm{H}(31)$ & 1.0000 \\
\hline $\mathrm{C}(14)-\mathrm{H}(14 \mathrm{~A})$ & ) 0.9900 & $\mathrm{C}(32)-\mathrm{C}(33)$ & $1.528(3)$ \\
\hline $\mathrm{C}(14)-\mathrm{H}(14 \mathrm{~B}) \mathrm{C}$ & 0.9900 & $\mathrm{C}(32)-\mathrm{H}(32 \mathrm{~A})$ & 0.9900 \\
\hline$C(15)-C(16)$ & $1.526(3)$ & \multicolumn{2}{|c|}{$\mathrm{C}(32)-\mathrm{H}(32 \mathrm{~B}) 0.9900$} \\
\hline $\mathrm{C}(15)-\mathrm{H}(15 \mathrm{~A})$ & 0.9900 & $\mathrm{C}(33)-\mathrm{C}(34)$ & $\begin{array}{l}0.9900 \\
1.529(3)\end{array}$ \\
\hline $\mathrm{C}(15)-\mathrm{H}(15 \mathrm{~B}) \mathrm{C}$ & 0.9900 & $\mathrm{C}(33)-\mathrm{H}(33 \mathrm{~A})$ & 0.9900 \\
\hline$C(16)-C(17)$ & $1.517(3)$ & $\mathrm{C}(33)-\mathrm{H}(33 \mathrm{~B})$ & 0.9900 \\
\hline $\mathrm{C}(16)-\mathrm{H}(16 \mathrm{~A})$ & 0.9900 & $\mathrm{C}(34)-\mathrm{C}(35)$ & $1.523(3)$ \\
\hline $\mathrm{C}(16)-\mathrm{H}(16 \mathrm{~B}) \mathrm{C}$ & 0.9900 & $\mathrm{C}(34)-\mathrm{H}(34 \mathrm{~A})$ & 0.9900 \\
\hline $\mathrm{C}(17)-\mathrm{C}(18)$ & $1.531(3)$ & $\mathrm{C}(34)-\mathrm{H}(34 \mathrm{~B})$ & 0.9900 \\
\hline C(17)-H(17A) & 0.9900 & $C(35)-C(36)$ & $1.527(3)$ \\
\hline $\mathrm{C}(17)-\mathrm{H}(17 \mathrm{~B}) \mathrm{C}$ & 0.9900 & $\mathrm{C}(35)-\mathrm{H}(35 \mathrm{~A})$ & 0.9900 \\
\hline $\mathrm{C}(18)-\mathrm{H}(18 \mathrm{~A})$ & 0.9900 & $\mathrm{C}(35)-\mathrm{H}(35 \mathrm{~B})$ & 0.9900 \\
\hline
\end{tabular}




\begin{tabular}{|c|c|}
\hline \multirow{2}{*}{\multicolumn{2}{|c|}{$\begin{array}{ll}\mathrm{C}(36)-\mathrm{H}(36 \mathrm{~A}) & 0.9900 \\
\mathrm{C}(36)-\mathrm{H}(36 \mathrm{~B}) & 0.9900\end{array}$}} \\
\hline & \\
\hline N(2)-C(1)-C(2) & $99.73(15)$ \\
\hline $\mathrm{N}(2)-\mathrm{C}(1)-\mathrm{C}(11)$ & $113.69(16)$ \\
\hline$C(2)-C(1)-C(11)$ & $111.47(15)$ \\
\hline $\mathrm{N}(2)-\mathrm{C}(1)-\mathrm{H}(1)$ & 110.5 \\
\hline $\mathrm{C}(2)-\mathrm{C}(1)-\mathrm{H}(1)$ & 110.5 \\
\hline $\mathrm{C}(11)-\mathrm{C}(1)-\mathrm{H}(1)$ & 110.5 \\
\hline$C(3)-C(2)-C(7)$ & $120.82(19)$ \\
\hline$C(3)-C(2)-C(1)$ & $127.92(18)$ \\
\hline$C(7)-C(2)-C(1)$ & $111.23(16)$ \\
\hline$C(2)-C(3)-C(4)$ & $118.3(2)$ \\
\hline $\mathrm{C}(2)-\mathrm{C}(3)-\mathrm{H}(3)$ & 120.8 \\
\hline $\mathrm{C}(4)-\mathrm{C}(3)-\mathrm{H}(3)$ & 120.8 \\
\hline$C(3)-C(4)-C(5)$ & $121.05(19)$ \\
\hline $\mathrm{C}(3)-\mathrm{C}(4)-\mathrm{H}(4)$ & 119.5 \\
\hline $\mathrm{C}(5)-\mathrm{C}(4)-\mathrm{H}(4)$ & 119.5 \\
\hline$C(6)-C(5)-C(4)$ & $120.82(19)$ \\
\hline $\mathrm{C}(6)-\mathrm{C}(5)-\mathrm{H}(5)$ & 119.6 \\
\hline $\mathrm{C}(4)-\mathrm{C}(5)-\mathrm{H}(5)$ & 119.6 \\
\hline$C(5)-C(6)-C(7)$ & $118.4(2)$ \\
\hline $\mathrm{C}(5)-\mathrm{C}(6)-\mathrm{H}(6)$ & 120.8 \\
\hline $\mathrm{C}(7)-\mathrm{C}(6)-\mathrm{H}(6)$ & 120.8 \\
\hline$C(6)-C(7)-C(2)$ & $120.52(18)$ \\
\hline $\mathrm{C}(6)-\mathrm{C}(7)-\mathrm{C}(8)$ & $132.03(19)$ \\
\hline $\mathrm{C}(2)-\mathrm{C}(7)-\mathrm{C}(8)$ & $107.45(17)$ \\
\hline $\mathrm{C}(9)-\mathrm{C}(8)-\mathrm{N}(2)$ & $105.63(17)$ \\
\hline $\mathrm{C}(9)-\mathrm{C}(8)-\mathrm{C}(7)$ & $146.67(19)$ \\
\hline $\mathrm{N}(2)-\mathrm{C}(8)-\mathrm{C}(7)$ & $107.62(16)$ \\
\hline $\mathrm{C}(8)-\mathrm{C}(9)-\mathrm{N}(1)$ & $109.46(18)$ \\
\hline $\mathrm{C}(8)-\mathrm{C}(9)-\mathrm{H}(9)$ & 125.3 \\
\hline N(1)-C(9)-H(9) & 125.3 \\
\hline $\mathrm{N}(1)-\mathrm{C}(10)-\mathrm{N}(2)$ & $111.16(17)$ \\
\hline $\mathrm{N}(1)-\mathrm{C}(10)-\mathrm{H}(10)$ & 124.4 \\
\hline $\mathrm{N}(2)-\mathrm{C}(10)-\mathrm{H}(10)$ & 124.4 \\
\hline $\mathrm{C}(12)-\mathrm{C}(11)-\mathrm{C}(1)$ & $114.83(15)$ \\
\hline $\mathrm{C}(12)-\mathrm{C}(11)-\mathrm{H}(11 \mathrm{~A})$ & 108.6 \\
\hline $\mathrm{C}(1)-\mathrm{C}(11)-\mathrm{H}(11 \mathrm{~A})$ & 108.6 \\
\hline $\mathrm{C}(12)-\mathrm{C}(11)-\mathrm{H}(11 \mathrm{~B})$ & 108.6 \\
\hline $\mathrm{C}(1)-\mathrm{C}(11)-\mathrm{H}(11 \mathrm{~B})$ & 108.6 \\
\hline $\mathrm{H}(11 \mathrm{~A})-\mathrm{C}(11)-\mathrm{H}(11 \mathrm{~B}$ & 3) $\quad 107.5$ \\
\hline $\mathrm{O}(1)-\mathrm{C}(12)-\mathrm{C}(11)$ & $108.68(16)$ \\
\hline $\mathrm{O}(1)-\mathrm{C}(12)-\mathrm{C}(13)$ & $112.39(16)$ \\
\hline$C(11)-C(12)-C(13)$ & $112.22(15)$ \\
\hline $\mathrm{O}(1)-\mathrm{C}(12)-\mathrm{H}(12)$ & 107.8 \\
\hline
\end{tabular}

$\begin{array}{lr}\mathrm{O}(1)-\mathrm{H}(1 \mathrm{~A}) & 0.8400 \\ \mathrm{O}(2)-\mathrm{H}(2) & 0.8400\end{array}$

$\begin{array}{ll}\mathrm{C}(11)-\mathrm{C}(12)-\mathrm{H}(12) & 107.8 \\ \mathrm{C}(13)-\mathrm{C}(12)-\mathrm{H}(12) & 107.8 \\ \mathrm{C}(14)-\mathrm{C}(13)-\mathrm{C}(18) & 109.76(16) \\ \mathrm{C}(14)-\mathrm{C}(13)-\mathrm{C}(12) & 114.50(16) \\ \mathrm{C}(18)-\mathrm{C}(13)-\mathrm{C}(12) & 110.20(15) \\ \mathrm{C}(14)-\mathrm{C}(13)-\mathrm{H}(13) & 107.4 \\ \mathrm{C}(18)-\mathrm{C}(13)-\mathrm{H}(13) & 107.4 \\ \mathrm{C}(12)-\mathrm{C}(13)-\mathrm{H}(13) & 107.4 \\ \mathrm{C}(13)-\mathrm{C}(14)-\mathrm{C}(15) & 111.30(17) \\ \mathrm{C}(13)-\mathrm{C}(14)-\mathrm{H}(14 \mathrm{~A}) & 109.4 \\ \mathrm{C}(15)-\mathrm{C}(14)-\mathrm{H}(14 \mathrm{~A}) & 109.4 \\ \mathrm{C}(13)-\mathrm{C}(14)-\mathrm{H}(14 \mathrm{~B}) & 109.4 \\ \mathrm{C}(15)-\mathrm{C}(14)-\mathrm{H}(14 \mathrm{~B}) & 109.4 \\ \mathrm{H}(14 \mathrm{~A})-\mathrm{C}(14)-\mathrm{H}(14 \mathrm{~B}) & 108.0 \\ \mathrm{C}(16)-\mathrm{C}(15)-\mathrm{C}(14) & 111.71(17) \\ \mathrm{C}(16)-\mathrm{C}(15)-\mathrm{H}(15 \mathrm{~A}) & 109.3 \\ \mathrm{C}(14)-\mathrm{C}(15)-\mathrm{H}(15 \mathrm{~A}) & 109.3 \\ \mathrm{C}(16)-\mathrm{C}(15)-\mathrm{H}(15 \mathrm{~B}) & 109.3 \\ \mathrm{C}(14)-\mathrm{C}(15)-\mathrm{H}(15 \mathrm{~B}) & 109.3\end{array}$

$\mathrm{H}(15 \mathrm{~A})-\mathrm{C}(15)-\mathrm{H}(15 \mathrm{~B}) \quad 107.9$

$\mathrm{C}(17)-\mathrm{C}(16)-\mathrm{C}(15) \quad 110.67(17)$

$\mathrm{C}(17)-\mathrm{C}(16)-\mathrm{H}(16 \mathrm{~A}) \quad 109.5$

$\mathrm{C}(15)-\mathrm{C}(16)-\mathrm{H}(16 \mathrm{~A}) \quad 109.5$

$\mathrm{C}(17)-\mathrm{C}(16)-\mathrm{H}(16 \mathrm{~B}) \quad 109.5$

$\mathrm{C}(15)-\mathrm{C}(16)-\mathrm{H}(16 \mathrm{~B}) \quad 109.5$

$\mathrm{H}(16 \mathrm{~A})-\mathrm{C}(16)-\mathrm{H}(16 \mathrm{~B}) \quad 108.1$

$\mathrm{C}(16)-\mathrm{C}(17)-\mathrm{C}(18) \quad 111.57(18)$

$\mathrm{C}(16)-\mathrm{C}(17)-\mathrm{H}(17 \mathrm{~A}) \quad 109.3$

C(18)-C(17)-H(17A) 109.3

C(16)-C(17)-H(17B) 109.3

$\mathrm{C}(18)-\mathrm{C}(17)-\mathrm{H}(17 \mathrm{~B}) \quad 109.3$

$\mathrm{H}(17 \mathrm{~A})-\mathrm{C}(17)-\mathrm{H}(17 \mathrm{~B}) \quad 108.0$

$\mathrm{C}(17)-\mathrm{C}(18)-\mathrm{C}(13) \quad 112.53(16)$

C(17)-C(18)-H(18A) 109.1

C(13)-C(18)-H(18A) 109.1

C(17)-C(18)-H(18B) 109.1

$\mathrm{C}(13)-\mathrm{C}(18)-\mathrm{H}(18 \mathrm{~B}) \quad 109.1$

$\mathrm{H}(18 \mathrm{~A})-\mathrm{C}(18)-\mathrm{H}(18 \mathrm{~B}) \quad 107.8$

$\mathrm{N}(4)-\mathrm{C}(19)-\mathrm{C}(20) \quad 99.89(14)$

$\mathrm{N}(4)-\mathrm{C}(19)-\mathrm{C}(29) \quad 112.79(15)$

$\mathrm{C}(20)-\mathrm{C}(19)-\mathrm{C}(29) \quad 111.06(15)$

$\mathrm{N}(4)-\mathrm{C}(19)-\mathrm{H}(19) \quad 110.9$

C(20)-C(19)-H(19) 110.9 


\begin{tabular}{|c|c|}
\hline $\mathrm{C}(29)-\mathrm{C}(19)-\mathrm{H}(19)$ & 110.9 \\
\hline$C(21)-C(20)-C(25)$ & $120.35(18)$ \\
\hline$C(21)-C(20)-C(19)$ & $128.47(17)$ \\
\hline$C(25)-C(20)-C(19)$ & $111.13(16)$ \\
\hline $\mathrm{C}(20)-\mathrm{C}(21)-\mathrm{C}(22)$ & 118.71(19) \\
\hline $\mathrm{C}(20)-\mathrm{C}(21)-\mathrm{H}(21)$ & 120.6 \\
\hline $\mathrm{C}(22)-\mathrm{C}(21)-\mathrm{H}(21)$ & 120.6 \\
\hline $\mathrm{C}(23)-\mathrm{C}(22)-\mathrm{C}(21)$ & $120.81(18)$ \\
\hline $\mathrm{C}(23)-\mathrm{C}(22)-\mathrm{H}(22)$ & 119.6 \\
\hline $\mathrm{C}(21)-\mathrm{C}(22)-\mathrm{H}(22)$ & 119.6 \\
\hline$C(22)-C(23)-C(24)$ & $120.96(19)$ \\
\hline $\mathrm{C}(22)-\mathrm{C}(23)-\mathrm{H}(23)$ & 119.5 \\
\hline $\mathrm{C}(24)-\mathrm{C}(23)-\mathrm{H}(23)$ & 119.5 \\
\hline$C(25)-C(24)-C(23)$ & $118.19(19)$ \\
\hline $\mathrm{C}(25)-\mathrm{C}(24)-\mathrm{H}(24)$ & 120.9 \\
\hline $\mathrm{C}(23)-\mathrm{C}(24)-\mathrm{H}(24)$ & 120.9 \\
\hline$C(24)-C(25)-C(20)$ & $120.99(17)$ \\
\hline$C(24)-C(25)-C(26)$ & $131.64(18)$ \\
\hline$C(20)-C(25)-C(26)$ & $107.36(17)$ \\
\hline $\mathrm{C}(27)-\mathrm{C}(26)-\mathrm{N}(4)$ & $105.50(17)$ \\
\hline$C(27)-C(26)-C(25)$ & $146.69(19)$ \\
\hline $\mathrm{N}(4)-\mathrm{C}(26)-\mathrm{C}(25)$ & $107.57(16)$ \\
\hline C(26)-C(27)-N(3) & $109.35(17)$ \\
\hline $\mathrm{C}(26)-\mathrm{C}(27)-\mathrm{H}(27)$ & 125.3 \\
\hline $\mathrm{N}(3)-\mathrm{C}(27)-\mathrm{H}(27)$ & 125.3 \\
\hline $\mathrm{N}(3)-\mathrm{C}(28)-\mathrm{N}(4)$ & $111.01(18)$ \\
\hline $\mathrm{N}(3)-\mathrm{C}(28)-\mathrm{H}(28)$ & 124.5 \\
\hline $\mathrm{N}(4)-\mathrm{C}(28)-\mathrm{H}(28)$ & 124.5 \\
\hline C(30)-C(29)-C(19) & $115.07(15)$ \\
\hline $\mathrm{C}(30)-\mathrm{C}(29)-\mathrm{H}(29 \mathrm{~A})$ & 108.5 \\
\hline $\mathrm{C}(19)-\mathrm{C}(29)-\mathrm{H}(29 \mathrm{~A})$ & 108.5 \\
\hline $\mathrm{C}(30)-\mathrm{C}(29)-\mathrm{H}(29 \mathrm{~B})$ & 108.5 \\
\hline C(19)-C(29)-H(29B) & 108.5 \\
\hline $\mathrm{H}(29 \mathrm{~A})-\mathrm{C}(29)-\mathrm{H}(29 \mathrm{~B}$ & ) $\quad 107.5$ \\
\hline $\mathrm{O}(2)-\mathrm{C}(30)-\mathrm{C}(29)$ & $108.78(15)$ \\
\hline $\mathrm{O}(2)-\mathrm{C}(30)-\mathrm{C}(31)$ & $112.82(15)$ \\
\hline $\mathrm{C}(29)-\mathrm{C}(30)-\mathrm{C}(31)$ & $111.53(15)$ \\
\hline $\mathrm{O}(2)-\mathrm{C}(30)-\mathrm{H}(30)$ & 107.8 \\
\hline $\mathrm{C}(29)-\mathrm{C}(30)-\mathrm{H}(30)$ & 107.8 \\
\hline $\mathrm{C}(31)-\mathrm{C}(30)-\mathrm{H}(30)$ & 107.8 \\
\hline $\mathrm{C}(30)-\mathrm{C}(31)-\mathrm{C}(32)$ & $114.53(15)$ \\
\hline $\mathrm{C}(30)-\mathrm{C}(31)-\mathrm{C}(36)$ & $111.57(15)$ \\
\hline $\mathrm{C}(32)-\mathrm{C}(31)-\mathrm{C}(36)$ & $109.85(15)$ \\
\hline $\mathrm{C}(30)-\mathrm{C}(31)-\mathrm{H}(31)$ & 106.8 \\
\hline $\mathrm{C}(32)-\mathrm{C}(31)-\mathrm{H}(31)$ & 106.8 \\
\hline $\mathrm{C}(36)-\mathrm{C}(31)-\mathrm{H}(31)$ & 106.8 \\
\hline
\end{tabular}

$\mathrm{C}(33)-\mathrm{C}(32)-\mathrm{C}(31) \quad 111.27(16)$

C(33)-C(32)-H(32A) 109.4

C(31)-C(32)-H(32A) 109.4

C(33)-C(32)-H(32B) 109.4

C(31)-C(32)-H(32B) 109.4

$\mathrm{H}(32 \mathrm{~A})-\mathrm{C}(32)-\mathrm{H}(32 \mathrm{~B}) \quad 108.0$

$\mathrm{C}(32)-\mathrm{C}(33)-\mathrm{C}(34) \quad 111.56(16)$

C(32)-C(33)-H(33A) 109.3

C(34)-C(33)-H(33A) 109.3

C(32)-C(33)-H(33B) 109.3

C(34)-C(33)-H(33B) 109.3

$\mathrm{H}(33 \mathrm{~A})-\mathrm{C}(33)-\mathrm{H}(33 \mathrm{~B}) \quad 108.0$

$\mathrm{C}(35)-\mathrm{C}(34)-\mathrm{C}(33) \quad 110.85(16)$

C(35)-C(34)-H(34A) 109.5

C(33)-C(34)-H(34A) 109.5

C(35)-C(34)-H(34B) 109.5

C(33)-C(34)-H(34B) 109.5

$\mathrm{H}(34 \mathrm{~A})-\mathrm{C}(34)-\mathrm{H}(34 \mathrm{~B}) \quad 108.1$

$\mathrm{C}(34)-\mathrm{C}(35)-\mathrm{C}(36) \quad 111.33(17)$

C(34)-C(35)-H(35A) 109.4

C(36)-C(35)-H(35A) 109.4

C(34)-C(35)-H(35B) 109.4

C(36)-C(35)-H(35B) 109.4

$\mathrm{H}(35 \mathrm{~A})-\mathrm{C}(35)-\mathrm{H}(35 \mathrm{~B}) \quad 108.0$

$\mathrm{C}(35)-\mathrm{C}(36)-\mathrm{C}(31) \quad 111.49(15)$

C(35)-C(36)-H(36A) 109.3

$\mathrm{C}(31)-\mathrm{C}(36)-\mathrm{H}(36 \mathrm{~A}) \quad 109.3$

C(35)-C(36)-H(36B) 109.3

C(31)-C(36)-H(36B) 109.3

$\mathrm{H}(36 \mathrm{~A})-\mathrm{C}(36)-\mathrm{H}(36 \mathrm{~B}) \quad 108.0$

$\mathrm{C}(10)-\mathrm{N}(1)-\mathrm{C}(9) \quad 105.91(16)$

$\mathrm{C}(10)-\mathrm{N}(2)-\mathrm{C}(8) \quad 107.83(16)$

$\mathrm{C}(10)-\mathrm{N}(2)-\mathrm{C}(1) \quad 138.30(17)$

$\mathrm{C}(8)-\mathrm{N}(2)-\mathrm{C}(1) \quad 113.78(15)$

$\mathrm{C}(28)-\mathrm{N}(3)-\mathrm{C}(27) \quad 106.00(16)$

$\mathrm{C}(28)-\mathrm{N}(4)-\mathrm{C}(26) \quad 108.12(16)$

$\mathrm{C}(28)-\mathrm{N}(4)-\mathrm{C}(19) \quad 138.39(17)$

$\mathrm{C}(26)-\mathrm{N}(4)-\mathrm{C}(19) \quad 113.48(15)$

$\mathrm{C}(12)-\mathrm{O}(1)-\mathrm{H}(1 \mathrm{~A}) \quad 109.5$

$\mathrm{C}(30)-\mathrm{O}(2)-\mathrm{H}(2) \quad 109.5$ 
Table 4. Anisotropic displacement parameters ( $\AA 2 \mathrm{x} 103)$ for Compound 7. The anisotropic displacement factor exponent takes the form: $-2 \square 2\left[\mathrm{~h} 2 \mathrm{a}^{*} 2 \mathrm{U} 11+\ldots+2 \mathrm{~h} \mathrm{k} \mathrm{a} * \mathrm{~b}^{*} \mathrm{U} 12\right.$ ]

\begin{tabular}{|c|c|c|c|c|c|c|}
\hline & U11 & U22 & U33 & U23 & U13 & U12 \\
\hline $\mathrm{C}(1)$ & $23(1)$ & $21(1)$ & $16(1)$ & $-1(1)$ & $5(1)$ & $1(1)$ \\
\hline $\mathrm{C}(2)$ & $20(1)$ & $22(1)$ & $20(1)$ & $0(1)$ & $4(1)$ & $-4(1)$ \\
\hline$C(3)$ & $28(1)$ & $28(1)$ & $23(1)$ & $-4(1)$ & $6(1)$ & $-2(1)$ \\
\hline$C(4)$ & $31(1)$ & $37(1)$ & $18(1)$ & $-3(1)$ & $3(1)$ & $-7(1)$ \\
\hline$C(5)$ & $24(1)$ & $35(1)$ & $20(1)$ & $6(1)$ & $-3(1)$ & $-7(1)$ \\
\hline$C(6)$ & $19(1)$ & $32(1)$ & $24(1)$ & $2(1)$ & 1(1) & $-1(1)$ \\
\hline$C(7)$ & $19(1)$ & $24(1)$ & $20(1)$ & $-1(1)$ & $4(1)$ & $-4(1)$ \\
\hline$C(8)$ & $19(1)$ & $23(1)$ & $20(1)$ & $2(1)$ & $3(1)$ & $0(1)$ \\
\hline$C(9)$ & $24(1)$ & $30(1)$ & $22(1)$ & $0(1)$ & $5(1)$ & $6(1)$ \\
\hline$C(10)$ & $23(1)$ & $26(1)$ & $17(1)$ & 1(1) & $5(1)$ & 1(1) \\
\hline $\mathrm{C}(11)$ & $22(1)$ & $25(1)$ & $18(1)$ & $0(1)$ & $7(1)$ & 1(1) \\
\hline$C(12)$ & $24(1)$ & $19(1)$ & $16(1)$ & 1(1) & $7(1)$ & 1(1) \\
\hline$C(13)$ & $23(1)$ & $21(1)$ & $17(1)$ & $2(1)$ & $5(1)$ & $2(1)$ \\
\hline$C(14)$ & $25(1)$ & $28(1)$ & $19(1)$ & $-2(1)$ & $7(1)$ & $0(1)$ \\
\hline$C(15)$ & $25(1)$ & $36(1)$ & $23(1)$ & $-1(1)$ & $10(1)$ & $-2(1)$ \\
\hline$C(16)$ & $23(1)$ & $35(1)$ & $32(1)$ & $3(1)$ & $7(1)$ & $2(1)$ \\
\hline$C(17)$ & $24(1)$ & $37(1)$ & $23(1)$ & $4(1)$ & $0(1)$ & $-1(1)$ \\
\hline$C(18)$ & $26(1)$ & $34(1)$ & $17(1)$ & $3(1)$ & $5(1)$ & $1(1)$ \\
\hline$C(19)$ & $20(1)$ & $20(1)$ & $15(1)$ & $3(1)$ & $5(1)$ & $-1(1)$ \\
\hline $\mathrm{C}(20)$ & $18(1)$ & $20(1)$ & $18(1)$ & $2(1)$ & 1(1) & $3(1)$ \\
\hline $\mathrm{C}(21)$ & $23(1)$ & $30(1)$ & $20(1)$ & $4(1)$ & $4(1)$ & 1(1) \\
\hline$C(22)$ & $26(1)$ & $40(1)$ & $15(1)$ & $0(1)$ & $3(1)$ & $2(1)$ \\
\hline$C(23)$ & $23(1)$ & $40(1)$ & $22(1)$ & $-6(1)$ & $-1(1)$ & $-1(1)$ \\
\hline$C(24)$ & $19(1)$ & $32(1)$ & $25(1)$ & $-1(1)$ & $3(1)$ & $-3(1)$ \\
\hline$C(25)$ & $17(1)$ & $24(1)$ & $17(1)$ & $3(1)$ & $3(1)$ & $4(1)$ \\
\hline$C(26)$ & $17(1)$ & $22(1)$ & $20(1)$ & $2(1)$ & 1(1) & 2(1) \\
\hline $\mathrm{C}(27)$ & $19(1)$ & $29(1)$ & $20(1)$ & $4(1)$ & $4(1)$ & 1(1) \\
\hline $\mathrm{C}(28)$ & $20(1)$ & $28(1)$ & $17(1)$ & $-1(1)$ & $2(1)$ & $4(1)$ \\
\hline $\mathrm{C}(29)$ & $19(1)$ & $22(1)$ & $17(1)$ & $0(1)$ & $4(1)$ & $-2(1)$ \\
\hline$C(30)$ & $21(1)$ & $17(1)$ & $16(1)$ & $1(1)$ & $7(1)$ & $-2(1)$ \\
\hline $\mathrm{C}(31)$ & $20(1)$ & $18(1)$ & $16(1)$ & $-1(1)$ & $2(1)$ & $-1(1)$ \\
\hline$C(32)$ & $20(1)$ & $23(1)$ & $20(1)$ & $0(1)$ & $5(1)$ & $-1(1)$ \\
\hline$C(33)$ & $20(1)$ & $31(1)$ & $24(1)$ & $-4(1)$ & $7(1)$ & 1(1) \\
\hline$C(34)$ & $17(1)$ & $31(1)$ & $29(1)$ & $-7(1)$ & $2(1)$ & $2(1)$ \\
\hline$C(35)$ & $24(1)$ & $31(1)$ & $19(1)$ & $-4(1)$ & $-1(1)$ & $4(1)$ \\
\hline$C(36)$ & $22(1)$ & $25(1)$ & $17(1)$ & $-2(1)$ & $4(1)$ & $-1(1)$ \\
\hline $\mathrm{N}(1)$ & $25(1)$ & $31(1)$ & $21(1)$ & $-1(1)$ & $6(1)$ & $3(1)$ \\
\hline $\mathrm{N}(2)$ & $19(1)$ & $22(1)$ & $16(1)$ & $0(1)$ & $5(1)$ & 1(1) \\
\hline $\mathrm{N}(3)$ & $21(1)$ & $32(1)$ & $16(1)$ & $3(1)$ & $5(1)$ & $3(1)$ \\
\hline $\mathrm{N}(4)$ & $17(1)$ & $23(1)$ & $17(1)$ & $2(1)$ & $3(1)$ & $1(1)$ \\
\hline $\mathrm{O}(1)$ & $29(1)$ & $21(1)$ & $17(1)$ & $1(1)$ & $6(1)$ & $0(1)$ \\
\hline
\end{tabular}


$\mathrm{O}(2) \quad 25(1) \quad 18(1) \quad 16(1) \quad-1(1) \quad 5(1) \quad 0(1)$ 
Table 5. Hydrogen coordinates ( x 104) and isotropic displacement parameters ( $₫ 2$ x 103) for Compound 7.

\begin{tabular}{lllll}
\hline- & $\mathrm{x}$ & $\mathrm{y}$ & $\mathrm{z}$ & $\mathrm{U}(\mathrm{eq})$ \\
\hline
\end{tabular}

$\begin{array}{llllll}\mathrm{H}(1) & 7576 & 11587 & 9083 & 24 & \\ \mathrm{H}(3) & 7617 & 10854 & 10565 & 31 & \\ \mathrm{H}(4) & 8526 & 8897 & 11465 & 34 & \\ \mathrm{H}(5) & 9478 & 5455 & 11255 & 32 & \\ \mathrm{H}(6) & 9593 & 4050 & 10133 & 30 & \\ \mathrm{H}(9) & 9376 & 3811 & 8446 & 30 & \\ \mathrm{H}(10) & 7517 & 8690 & 7651 & 26 & \\ \mathrm{H}(11 \mathrm{~A}) & 6615 & 6591 & 9263 & 25 \\ \mathrm{H}(11 \mathrm{~B}) & 6417 & 9648 & 9542 & 25 \\ \mathrm{H}(12) & 6242 & 8008 & 8137 & 23 & \\ \mathrm{H}(13) & 5120 & 6411 & 8628 & 24 & \\ \mathrm{H}(14 \mathrm{~A}) & 4851 & 11992 & 9116 & 28 \\ \mathrm{H}(14 \mathrm{~B}) & 5145 & 9345 & 9594 & 28 \\ \mathrm{H}(15 \mathrm{~A}) & 3869 & 7046 & 9265 & 33 \\ \mathrm{H}(15 \mathrm{~B}) & 3695 & 10104 & 9561 & 33 \\ \mathrm{H}(16 \mathrm{~A}) & 2787 & 9171 & 8530 & 35 \\ \mathrm{H}(16 \mathrm{~B}) & 3345 & 11903 & 8447 & 35 \\ \mathrm{H}(17 \mathrm{~A}) & 3354 & 9072 & 7477 & 34 \\ \mathrm{H}(17 \mathrm{~B}) & 3635 & 6374 & 7941 & 34 \\ \mathrm{H}(18 \mathrm{~A}) & 4640 & 11254 & 7795 & 30 \\ \mathrm{H}(18 \mathrm{~B}) & 4800 & 8169 & 7508 & 30 \\ \mathrm{H}(19) & 7424 & 4810 & 5396 & 22 & \\ \mathrm{H}(21) & 7488 & 2409 & 4040 & 29 & \\ \mathrm{H}(22) & 6635 & -355 & 3246 & 33 & \\ \mathrm{H}(23) & 5587 & -3107 & 3592 & 35 & \\ \mathrm{H}(24) & 5377 & -3235 & 4744 & 31 & \\ \mathrm{H}(27) & 5501 & -1839 & 6389 & 27 & \\ \mathrm{H}(28) & 7255 & 3855 & 6931 & 26 & \\ \mathrm{H}(29 \mathrm{~A}) & 8302 & -487 & 5550 & 23 \\ \mathrm{H}(29 \mathrm{~B}) & 8631 & 2361 & 5247 & 23 \\ \mathrm{H}(30) & 8506 & 1301 & 6653 & 21 & \\ \mathrm{H}(31) & 9667 & -745 & 6232 & 21 & \\ \mathrm{H}(32 \mathrm{~A}) & 9967 & 2662 & 5429 & 24 \\ \mathrm{H}(32 \mathrm{~B}) & 10251 & 4859 & 6033 & 24 \\ \mathrm{H}(33 \mathrm{~A}) & 11438 & 2704 & 5705 & 30 \\ \mathrm{H}(33 \mathrm{~B}) & 11073 & -370 & 5824 & 30 \\ \mathrm{H}(34 \mathrm{~A}) & 12055 & 741 & 6773 & 31 \\ \mathrm{H}(34 \mathrm{~B}) & 11592 & 3654 & 6886 & 31 \\ & & & & & \end{array}$


$\begin{array}{lllll}\mathrm{H}(35 \mathrm{~A}) & 11229 & 346 & 7680 & 30\end{array}$

$\mathrm{H}(35 \mathrm{~B}) \quad 10940-1871 \quad 7081 \quad 30$

$\begin{array}{lllll}\mathrm{H}(36 \mathrm{~A}) & 10124 & 3380 & 7278 & 26\end{array}$

$\begin{array}{lllll}\mathrm{H}(36 \mathrm{~B}) & 9759 & 318 & 7409 & 26\end{array}$

H(1A) $6182 \quad 12193 \quad 7890 \quad 33$

H(2) $\quad 8697 \quad 5566 \quad 6832 \quad 29$ 


\section{Experimental data for SC-XRD on Compound 8}

X-ray quality crystals were grown from a saturated 1,2-dichloroethane/ethanol/methanol solution followed by the slow vapor diffusion of diethyl ether to deposit the crystal diffracted. A colorless rod $0.080 \times 0.050 \times 0.050 \mathrm{~mm}$ in size was mounted on a Cryoloop with Paratone oil. Data were collected in a nitrogen gas stream at 90(2) K using phi and omega scans. Crystal-todetector distance was $40 \mathrm{~mm}$ and exposure time was 0.05 seconds per frame using a scan width of $0.5^{\circ}$. Data collection was $99.9 \%$ complete to $67.000^{\circ}$ in theta. A total of 17678 reflections were collected covering the indices, $-8<=h<=8,-11<=k<=11,-18<=l<=18.6643$ reflections were found to be symmetry independent, with an $\mathrm{R}_{\text {int }}$ of 0.0255 . Indexing and unit cell refinement indicated a primitive, triclinic lattice. The space group was found to be $\mathrm{P} 1$ (No. 1). The data were integrated and scaled using CrysAlisPro 1.171.40.35a. Solution by iterative methods (SHELXT-2014) produced a complete heavy-atom phasing model. All non-hydrogen atoms were refined anisotropically by full-matrix least-squares (SHELXL-2018). All hydrogen atoms were placed using a riding model. Their positions were constrained relative to their parent atom using the appropriate HFIX command in SHELXL-2018. Absolute stereochemistry was unambiguously determined to be $R$ at $\mathrm{C} 11$ and $\mathrm{C} 30$, and $S$ at $\mathrm{C} 1, \mathrm{C} 13, \mathrm{C} 20$, and $\mathrm{C} 32$, respectively. 
Table 1. Crystal data and structure refinement for Compound 8.

X-ray ID Compound 8

Sample/notebook ID Compound 8

Empirical formula $\quad$ C38 H55 Cl N4 O5

Formula weight 683.31

Temperature 90(2) K

Wavelength $1.54184 \AA$

Crystal system Triclinic

Space group P 1

Unit cell dimensions $\mathrm{a}=6.81630(10) \AA \quad$ alpha $=73.148(2)^{\circ}$.

$$
\begin{array}{ll}
\mathrm{b}=9.5313(2) \AA & \text { beta }=77.8340(10)^{\circ} . \\
\mathrm{c}=15.3468(2) \AA & \text { gamma }=89.575(2)^{\circ} .
\end{array}
$$

Volume $\quad 931.27(3) \AA 3$

Z 1

Density (calculated) $\quad 1.218 \mathrm{Mg} / \mathrm{m} 3$

Absorption coefficient $\quad 1.278 \mathrm{~mm}-1$

$\mathrm{F}(000) 368$

Crystal size $\quad 0.080 \times 0.050 \times 0.050 \mathrm{~mm} 3$

Theta range for data collection $\quad 3.083$ to $75.128^{\circ}$.

Index ranges $-8<=\mathrm{h}<=8,-11<=\mathrm{k}<=11,-18<=\mathrm{l}<=18$

Reflections collected 17678

Independent reflections $\quad 6643[\mathrm{R}(\mathrm{int})=0.0255]$

Completeness to theta $=67.000^{\circ} \quad 99.9 \%$

Absorption correction Semi-empirical from equivalents

Max. and min. transmission 1.00000 and 0.83098

Refinement method Full-matrix least-squares on F2

Data / restraints / parameters 6643 / 3 / 437

Goodness-of-fit on F2 1.053

Final $\mathrm{R}$ indices $[\mathrm{I}>2 \operatorname{sigma}(\mathrm{I})] \mathrm{R} 1=0.0420, \mathrm{wR} 2=0.1122$

$\mathrm{R}$ indices (all data) $\mathrm{R} 1=0.0429, \mathrm{wR} 2=0.1136$

Absolute structure parameter 0.050(7)

Extinction coefficient $\mathrm{n} / \mathrm{a}$

Largest diff. peak and hole $\quad 0.476$ and -0.486 e. $\AA-3$ 
Table 2. Atomic coordinates ( $\mathrm{x} 104)$ and equivalent isotropic displacement parameters ( $\AA 2 \mathrm{x}$ 103)

for Compound 8. $\mathrm{U}(\mathrm{eq})$ is defined as one third of the trace of the orthogonalized Uij tensor.

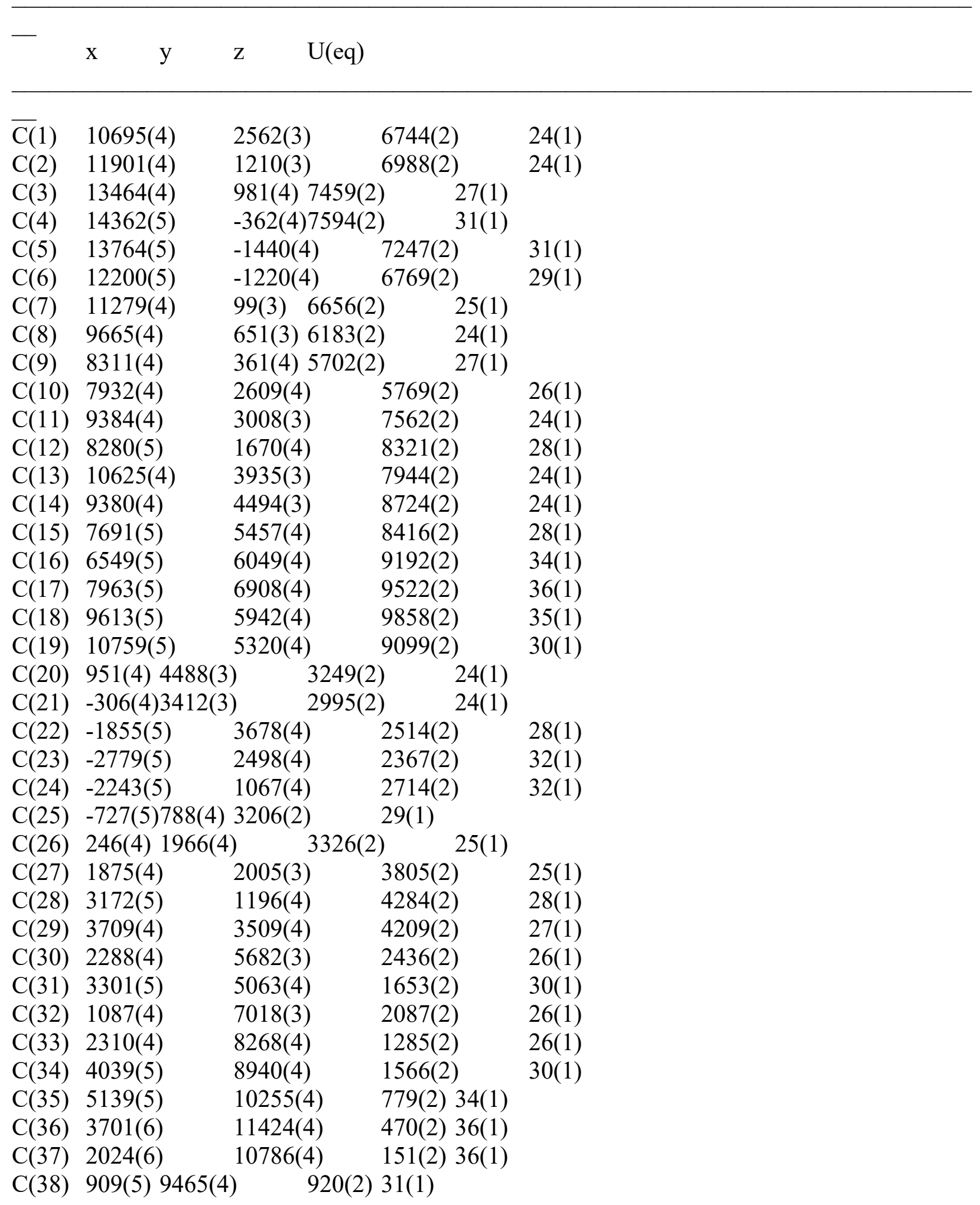




$\begin{array}{lllll}\mathrm{N}(1) & 7260(4) & 1609(3) & 5449(2) & 27(1) \\ \mathrm{N}(2) & 9390(4) & 2067(3) & 6222(2) & 24(1) \\ \mathrm{N}(3) & 4287(4) & 2162(3) & 4530(2) & 27(1) \\ \mathrm{N}(4) & 2238(4) & 3445(3) & 3765(2) & 24(1) \\ \mathrm{O}(1) & 11712(3) & 5124(2) & 7208(2) & 30(1) \\ \mathrm{O}(2) & 286(4) 7600(3) & 2838(2) \quad 37(1) & \\ \mathrm{O}(3) & 1980(5) & 7781(4) & 4272(3) & 64(1) \\ \mathrm{O}(4) & -594(5) 6502(4) & 5929(2) \quad 68(1) & \\ \mathrm{O}(5) & -4382(4) & 5505(4) & 6107(2) & 57(1) \\ \mathrm{Cl}(1) & -3796(1) & 6703(1) & 3944(1) & 58(1)\end{array}$


Table 3. Bond lengths $[\AA]$ and angles $\left[^{\circ}\right]$ for Compound 8.

\begin{tabular}{|c|c|c|c|}
\hline $\mathrm{C}(1)-\mathrm{N}(2)$ & $1.477(4)$ & $\mathrm{C}(18)-\mathrm{H}(18 \mathrm{~A})$ & 0.9900 \\
\hline $\mathrm{C}(1)-\mathrm{C}(2)$ & $1.520(4)$ & \multicolumn{2}{|c|}{$\mathrm{C}(18)-\mathrm{H}(18 \mathrm{~B}) 0.9900$} \\
\hline $\mathrm{C}(1)-\mathrm{C}(11)$ & $1.544(4)$ & $\mathrm{C}(19)-\mathrm{H}(19 \mathrm{~A})$ & $\quad 0.9900$ \\
\hline $\mathrm{C}(1)-\mathrm{H}(1)$ & 1.0000 & \\
\hline $\mathrm{C}(2)-\mathrm{C}(3)$ & $1.392(4)$ & \multicolumn{2}{|c|}{$\begin{array}{ll}\mathrm{C}(19)-\mathrm{H}(19 \mathrm{~B}) & 0.9900 \\
\mathrm{C}(20)-\mathrm{N}(4) & 1.486(4)\end{array}$} \\
\hline $\mathrm{C}(2)-\mathrm{C}(7)$ & $1.403(4)$ & $\mathrm{C}(20)-\mathrm{C}(21)$ & $1.525(4)$ \\
\hline$C(3)-C(4)$ & $1.394(5)$ & $C(20)-C(30)$ & $1.547(4)$ \\
\hline $\mathrm{C}(3)-\mathrm{H}(3)$ & 0.9500 & $\mathrm{C}(20)-\mathrm{H}(20)$ & 1.0000 \\
\hline$C(4)-C(5)$ & $1.386(5)$ & $C(21)-C(22)$ & $1.392(4)$ \\
\hline $\mathrm{C}(4)-\mathrm{H}(4)$ & 0.9500 & $C(21)-C(26)$ & $1.402(4)$ \\
\hline$C(5)-C(6)$ & $1.399(4)$ & $C(22)-C(23)$ & $1.389(5)$ \\
\hline $\mathrm{C}(5)-\mathrm{H}(5)$ & 0.9500 & $\mathrm{C}(22)-\mathrm{H}(22)$ & 0.9500 \\
\hline$C(6)-C(7)$ & $1.384(4)$ & $C(23)-C(24)$ & $1.390(5)$ \\
\hline $\mathrm{C}(6)-\mathrm{H}(6)$ & 0.9500 & $\mathrm{C}(23)-\mathrm{H}(23)$ & 0.9500 \\
\hline $\mathrm{C}(7)-\mathrm{C}(8)$ & $1.456(4)$ & $C(24)-C(25)$ & $1.385(4)$ \\
\hline $\mathrm{C}(8)-\mathrm{C}(9)$ & $1.372(4)$ & $\mathrm{C}(24)-\mathrm{H}(24)$ & 0.9500 \\
\hline $\mathrm{C}(8)-\mathrm{N}(2)$ & $1.378(4)$ & $C(25)-C(26)$ & $1.385(4)$ \\
\hline $\mathrm{C}(9)-\mathrm{N}(1)$ & $1.384(4)$ & $\mathrm{C}(25)-\mathrm{H}(25)$ & 0.9500 \\
\hline $\mathrm{C}(9)-\mathrm{H}(9)$ & 0.9500 & $\mathrm{C}(26)-\mathrm{C}(27)$ & $1.460(4)$ \\
\hline $\mathrm{C}(10)-\mathrm{N}(1)$ & $1.316(4)$ & $C(27)-C(28)$ & $1.360(4)$ \\
\hline $\mathrm{C}(10)-\mathrm{N}(2)$ & $1.347(4)$ & $\mathrm{C}(27)-\mathrm{N}(4)$ & $1.378(4)$ \\
\hline $\mathrm{C}(10)-\mathrm{H}(10)$ & 0.9500 & $\mathrm{C}(28)-\mathrm{N}(3)$ & \multirow{2}{*}{$1.379(4)$} \\
\hline $\mathrm{C}(11)-\mathrm{C}(12)$ & $1.527(4)$ & $\mathrm{C}(28)-\mathrm{H}(28)$ & \\
\hline $\mathrm{C}(11)-\mathrm{C}(13)$ & $1.536(4)$ & $\mathrm{C}(29)-\mathrm{N}(3)$ & $1.325(4)$ \\
\hline $\mathrm{C}(11)-\mathrm{H}(11)$ & 1.0000 & $\mathrm{C}(29)-\mathrm{N}(4)$ & $1.337(4)$ \\
\hline $\mathrm{C}(12)-\mathrm{H}(12 \mathrm{~A})$ & 0.9800 & $\mathrm{C}(29)-\mathrm{H}(29)$ & 0.9500 \\
\hline $\mathrm{C}(12)-\mathrm{H}(12 \mathrm{~B})$ & 0.9800 & $\mathrm{C}(30)-\mathrm{C}(31)$ & $1.525(4)$ \\
\hline $\mathrm{C}(12)-\mathrm{H}(12 \mathrm{C})$ & 0.9800 & $\mathrm{C}(30)-\mathrm{C}(32)$ & $1.534(4)$ \\
\hline $\mathrm{C}(13)-\mathrm{O}(1)$ & $1.423(4)$ & $\mathrm{C}(30)-\mathrm{H}(30)$ & 1.0000 \\
\hline $\mathrm{C}(13)-\mathrm{C}(14)$ & $1.541(4)$ & $\mathrm{C}(31)-\mathrm{H}(31 \mathrm{~A})$ & $\quad 0.9800$ \\
\hline $\mathrm{C}(13)-\mathrm{H}(13)$ & 1.0000 & $\mathrm{C}(31)-\mathrm{H}(31 \mathrm{~B})$ & 0.9800 \\
\hline $\mathrm{C}(14)-\mathrm{C}(19)$ & $1.528(4)$ & $\mathrm{C}(31)-\mathrm{H}(31 \mathrm{C})$ & 0.9800 \\
\hline$C(14)-C(15)$ & $1.534(4)$ & $\mathrm{C}(32)-\mathrm{O}(2)$ & $1.426(3)$ \\
\hline $\mathrm{C}(14)-\mathrm{H}(14)$ & 1.0000 & $C(32)-C(33)$ & $1.537(4)$ \\
\hline$C(15)-C(16)$ & $1.528(4)$ & $\mathrm{C}(32)-\mathrm{H}(32)$ & 1.0000 \\
\hline $\mathrm{C}(15)-\mathrm{H}(15 \mathrm{~A})$ & 0.9900 & $C(33)-C(38)$ & $1.538(4)$ \\
\hline $\mathrm{C}(15)-\mathrm{H}(15 \mathrm{~B})$ & 0.9900 & $\mathrm{C}(33)-\mathrm{C}(34)$ & $1.539(4)$ \\
\hline$C(16)-C(17)$ & $1.522(5)$ & $\mathrm{C}(33)-\mathrm{H}(33)$ & 1.0000 \\
\hline $\mathrm{C}(16)-\mathrm{H}(16 \mathrm{~A})$ & 0.9900 & $\mathrm{C}(34)-\mathrm{C}(35)$ & $1.531(5)$ \\
\hline $\mathrm{C}(16)-\mathrm{H}(16 \mathrm{~B})$ & 0.9900 & $\mathrm{C}(34)-\mathrm{H}(34 \mathrm{~A})$ & $\quad 0.9900$ \\
\hline $\mathrm{C}(17)-\mathrm{C}(18)$ & $1.527(5)$ & $\mathrm{C}(34)-\mathrm{H}(34 \mathrm{~B})$ & 0.9900 \\
\hline $\mathrm{C}(17)-\mathrm{H}(17 \mathrm{~A})$ & 0.9900 & $C(35)-C(36)$ & $1.517(5)$ \\
\hline $\mathrm{C}(17)-\mathrm{H}(17 \mathrm{~B})$ & 0.9900 & $\mathrm{C}(35)-\mathrm{H}(35 \mathrm{~A})$ & $\quad 0.9900$ \\
\hline$C(18)-C(19)$ & $1.526(4)$ & $\mathrm{C}(35)-\mathrm{H}(35 \mathrm{~B})$ & 0.9900 \\
\hline
\end{tabular}




$\begin{array}{ll}\mathrm{C}(36)-\mathrm{C}(37) & 1.528(5) \\ \mathrm{C}(36)-\mathrm{H}(36 \mathrm{~A}) & 0.9900 \\ \mathrm{C}(36)-\mathrm{H}(36 \mathrm{~B}) & 0.9900 \\ \mathrm{C}(37)-\mathrm{C}(38) & 1.526(5) \\ \mathrm{C}(37)-\mathrm{H}(37 \mathrm{~A}) & 0.9900 \\ \mathrm{C}(37)-\mathrm{H}(37 \mathrm{~B}) & 0.9900 \\ \mathrm{C}(38)-\mathrm{H}(38 \mathrm{~A}) & 0.9900 \\ \mathrm{C}(38)-\mathrm{H}(38 \mathrm{~B}) & 0.9900 \\ \mathrm{~N}(3)-\mathrm{H}(3 \mathrm{~A}) & 0.8800 \\ & \\ \mathrm{~N}(2)-\mathrm{C}(1)-\mathrm{C}(2) & 99.7(2) \\ \mathrm{N}(2)-\mathrm{C}(1)-\mathrm{C}(11) & 109.6(2) \\ \mathrm{C}(2)-\mathrm{C}(1)-\mathrm{C}(11) & 117.3(2) \\ \mathrm{N}(2)-\mathrm{C}(1)-\mathrm{H}(1) & 109.9 \\ \mathrm{C}(2)-\mathrm{C}(1)-\mathrm{H}(1) & 109.9 \\ \mathrm{C}(11)-\mathrm{C}(1)-\mathrm{H}(1) & 109.9 \\ \mathrm{C}(3)-\mathrm{C}(2)-\mathrm{C}(7) & 119.6(3) \\ \mathrm{C}(3)-\mathrm{C}(2)-\mathrm{C}(1) & 129.0(3) \\ \mathrm{C}(7)-\mathrm{C}(2)-\mathrm{C}(1) & 111.4(2) \\ \mathrm{C}(2)-\mathrm{C}(3)-\mathrm{C}(4) & 118.6(3) \\ \mathrm{C}(2)-\mathrm{C}(3)-\mathrm{H}(3) & 120.7 \\ \mathrm{C}(4)-\mathrm{C}(3)-\mathrm{H}(3) & 120.7 \\ \mathrm{C}(5)-\mathrm{C}(4)-\mathrm{C}(3) & 121.3(3) \\ \mathrm{C}(5)-\mathrm{C}(4)-\mathrm{H}(4) & 119.4 \\ \mathrm{C}(3)-\mathrm{C}(4)-\mathrm{H}(4) & 119.4 \\ \mathrm{C}(4)-\mathrm{C}(5)-\mathrm{C}(6) & 120.6(3) \\ \mathrm{C}(4)-\mathrm{C}(5)-\mathrm{H}(5) & 119.7 \\ \mathrm{C}(6)-\mathrm{C}(5)-\mathrm{H}(5) & 119.7 \\ \mathrm{C}(7)-\mathrm{C}(6)-\mathrm{C}(5) & 117.9(3) \\ \mathrm{C}(7)-\mathrm{C}(6)-\mathrm{H}(6) & 121.0 \\ \mathrm{C}(5)-\mathrm{C}(6)-\mathrm{H}(6) & 121.0 \\ \mathrm{C}(6)-\mathrm{C}(7)-\mathrm{C}(2) & 121.9(3) \\ \mathrm{C}(6)-\mathrm{C}(7)-\mathrm{C}(8) & 130.5(3) \\ \mathrm{C}(2)-\mathrm{C}(7)-\mathrm{C}(8) & 107.5(3) \\ \mathrm{C}(9)-\mathrm{C}(8)-\mathrm{N}(2) & 106.2(3) \\ \mathrm{C}(9)-\mathrm{C}(8)-\mathrm{C}(7) & 146.4(3) \\ \mathrm{N}(2)-\mathrm{C}(8)-\mathrm{C}(7) & 107.4(2) \\ \mathrm{C}(8)-\mathrm{C}(9)-\mathrm{N}(1) & 107.7(3) \\ \mathrm{C}(8)-\mathrm{C}(9)-\mathrm{H}(9) & 126.2 \\ \mathrm{~N}(1)-\mathrm{C}(9)-\mathrm{H}(9) & 126.2 \\ \mathrm{~N}(1)-\mathrm{C}(10)-\mathrm{N}(2) & 109.7(3) \\ \mathrm{N}(1)-\mathrm{C}(10)-\mathrm{H}(10) & 125.2 \\ \mathrm{~N}(1)-\mathrm{C}(10)-\mathrm{H}(10) & 125.2 \\ \mathrm{C}(1) & 111.4(2) \\ \mathrm{C}(1) & 11.2(2) \\ & \end{array}$

$\begin{array}{ll}\mathrm{O}(1)-\mathrm{H}(1 \mathrm{~A}) & 0.8400 \\ \mathrm{O}(2)-\mathrm{H}(2) & 0.8400 \\ \mathrm{O}(3)-\mathrm{H}(3 \mathrm{X}) & 0.8501 \\ \mathrm{O}(3)-\mathrm{H}(3 \mathrm{Y}) & 0.8500 \\ \mathrm{O}(4)-\mathrm{H}(4 \mathrm{X}) & 0.8411 \\ \mathrm{O}(4)-\mathrm{H}(4 \mathrm{Y}) & 0.8444 \\ \mathrm{O}(5)-\mathrm{H}(5 \mathrm{X}) & 0.8500 \\ \mathrm{O}(5)-\mathrm{H}(5 \mathrm{Y}) & 0.8501\end{array}$

$\mathrm{C}(12)-\mathrm{C}(11)-\mathrm{H}(11) \quad 107.2$

$\mathrm{C}(13)-\mathrm{C}(11)-\mathrm{H}(11) \quad 107.2$

$\mathrm{C}(1)-\mathrm{C}(11)-\mathrm{H}(11) \quad 107.2$

C(11)-C(12)-H(12A) 109.5

C(11)-C(12)-H(12B) 109.5

$\mathrm{H}(12 \mathrm{~A})-\mathrm{C}(12)-\mathrm{H}(12 \mathrm{~B}) \quad 109.5$

$\mathrm{C}(11)-\mathrm{C}(12)-\mathrm{H}(12 \mathrm{C}) \quad 109.5$

$\mathrm{H}(12 \mathrm{~A})-\mathrm{C}(12)-\mathrm{H}(12 \mathrm{C}) \quad 109.5$

$\mathrm{H}(12 \mathrm{~B})-\mathrm{C}(12)-\mathrm{H}(12 \mathrm{C}) \quad 109.5$

$\mathrm{O}(1)-\mathrm{C}(13)-\mathrm{C}(11) \quad 110.7(2)$

$\mathrm{O}(1)-\mathrm{C}(13)-\mathrm{C}(14) \quad 110.7(2)$

$\mathrm{C}(11)-\mathrm{C}(13)-\mathrm{C}(14) \quad 113.9(2)$

$\mathrm{O}(1)-\mathrm{C}(13)-\mathrm{H}(13) \quad 107.1$

C(11)-C(13)-H(13) 107.1

C(14)-C(13)-H(13) 107.1

$\mathrm{C}(19)-\mathrm{C}(14)-\mathrm{C}(15) \quad 110.5(2)$

$\mathrm{C}(19)-\mathrm{C}(14)-\mathrm{C}(13) \quad 110.0(2)$

$\mathrm{C}(15)-\mathrm{C}(14)-\mathrm{C}(13) \quad 113.1(2)$

C(19)-C(14)-H(14) 107.7

C(15)-C(14)-H(14) 107.7

C(13)-C(14)-H(14) 107.7

C(16)-C(15)-C(14) 111.7(2)

C(16)-C(15)-H(15A) 109.3

C(14)-C(15)-H(15A) 109.3

C(16)-C(15)-H(15B) 109.3

$\mathrm{C}(14)-\mathrm{C}(15)-\mathrm{H}(15 \mathrm{~B}) \quad 109.3$

$\mathrm{H}(15 \mathrm{~A})-\mathrm{C}(15)-\mathrm{H}(15 \mathrm{~B}) \quad 107.9$

$\mathrm{C}(17)-\mathrm{C}(16)-\mathrm{C}(15) \quad 111.2(3)$

$\mathrm{C}(17)-\mathrm{C}(16)-\mathrm{H}(16 \mathrm{~A}) \quad 109.4$

C(15)-C(16)-H(16A) 109.4

C(17)-C(16)-H(16B) 109.4

C(15)-C(16)-H(16B) 109.4

$\mathrm{H}(16 \mathrm{~A})-\mathrm{C}(16)-\mathrm{H}(16 \mathrm{~B}) \quad 108.0$

$\mathrm{C}(16)-\mathrm{C}(17)-\mathrm{C}(18) \quad 110.2(3)$

C(16)-C(17)-H(17A) 109.6

C(18)-C(17)-H(17A) 109.6 
C(16)-C(17)-H(17B) 109.6

C(18)-C(17)-H(17B) 109.6

$\mathrm{H}(17 \mathrm{~A})-\mathrm{C}(17)-\mathrm{H}(17 \mathrm{~B}) \quad 108.1$

$\mathrm{C}(19)-\mathrm{C}(18)-\mathrm{C}(17) \quad 111.3(3)$

C(19)-C(18)-H(18A) 109.4

C(17)-C(18)-H(18A) 109.4

C(19)-C(18)-H(18B) 109.4

C(17)-C(18)-H(18B) 109.4

$\mathrm{H}(18 \mathrm{~A})-\mathrm{C}(18)-\mathrm{H}(18 \mathrm{~B}) \quad 108.0$

$\mathrm{C}(18)-\mathrm{C}(19)-\mathrm{C}(14) \quad 112.8(3)$

C(18)-C(19)-H(19A) 109.0

C(14)-C(19)-H(19A) 109.0

C(18)-C(19)-H(19B) 109.0

C(14)-C(19)-H(19B) 109.0

$\mathrm{H}(19 \mathrm{~A})-\mathrm{C}(19)-\mathrm{H}(19 \mathrm{~B}) \quad 107.8$

$\mathrm{N}(4)-\mathrm{C}(20)-\mathrm{C}(21) \quad 99.7(2)$

$\mathrm{N}(4)-\mathrm{C}(20)-\mathrm{C}(30) \quad 109.8(2)$

$\mathrm{C}(21)-\mathrm{C}(20)-\mathrm{C}(30) \quad 117.3(2)$

$\mathrm{N}(4)-\mathrm{C}(20)-\mathrm{H}(20) \quad 109.9$

C(21)-C(20)-H(20) 109.9

$\mathrm{C}(30)-\mathrm{C}(20)-\mathrm{H}(20) \quad 109.9$

$\mathrm{C}(22)-\mathrm{C}(21)-\mathrm{C}(26) \quad 119.1(3)$

$\mathrm{C}(22)-\mathrm{C}(21)-\mathrm{C}(20) \quad 129.5(3)$

$\mathrm{C}(26)-\mathrm{C}(21)-\mathrm{C}(20) \quad 111.4(2)$

$\mathrm{C}(23)-\mathrm{C}(22)-\mathrm{C}(21) \quad 118.6(3)$

$\mathrm{C}(23)-\mathrm{C}(22)-\mathrm{H}(22) \quad 120.7$

$\mathrm{C}(21)-\mathrm{C}(22)-\mathrm{H}(22) \quad 120.7$

$\mathrm{C}(22)-\mathrm{C}(23)-\mathrm{C}(24) \quad 121.7(3)$

$\mathrm{C}(22)-\mathrm{C}(23)-\mathrm{H}(23) \quad 119.1$

$\mathrm{C}(24)-\mathrm{C}(23)-\mathrm{H}(23) \quad 119.1$

$\mathrm{C}(25)-\mathrm{C}(24)-\mathrm{C}(23) \quad 120.1(3)$

$\mathrm{C}(25)-\mathrm{C}(24)-\mathrm{H}(24) \quad 120.0$

$\mathrm{C}(23)-\mathrm{C}(24)-\mathrm{H}(24) \quad 120.0$

$\mathrm{C}(26)-\mathrm{C}(25)-\mathrm{C}(24) \quad 118.4(3)$

$\mathrm{C}(26)-\mathrm{C}(25)-\mathrm{H}(25) \quad 120.8$

$\mathrm{C}(24)-\mathrm{C}(25)-\mathrm{H}(25) \quad 120.8$

$\mathrm{C}(25)-\mathrm{C}(26)-\mathrm{C}(21) \quad 122.0(3)$

$\mathrm{C}(25)-\mathrm{C}(26)-\mathrm{C}(27) \quad 130.4(3)$

$\mathrm{C}(21)-\mathrm{C}(26)-\mathrm{C}(27) \quad 107.6(3)$

$\mathrm{C}(28)-\mathrm{C}(27)-\mathrm{N}(4) \quad 106.8(3)$

$\mathrm{C}(28)-\mathrm{C}(27)-\mathrm{C}(26) \quad 145.6(3)$

$\mathrm{N}(4)-\mathrm{C}(27)-\mathrm{C}(26) \quad 107.5(3)$

$\mathrm{C}(27)-\mathrm{C}(28)-\mathrm{N}(3) \quad 106.8(3)$

$\mathrm{C}(27)-\mathrm{C}(28)-\mathrm{H}(28) \quad 126.6$

$\mathrm{N}(3)-\mathrm{C}(28)-\mathrm{H}(28) \quad 126.6$

$\mathrm{N}(3)-\mathrm{C}(29)-\mathrm{N}(4) \quad 108.4(3)$
$\begin{array}{ll}\mathrm{N}(3)-\mathrm{C}(29)-\mathrm{H}(29) & 125.8 \\ \mathrm{~N}(4)-\mathrm{C}(29)-\mathrm{H}(29) & 125.8 \\ \mathrm{C}(31)-\mathrm{C}(30)-\mathrm{C}(32) & 112.3(2) \\ \mathrm{C}(31)-\mathrm{C}(30)-\mathrm{C}(20) & 111.5(3) \\ \mathrm{C}(32)-\mathrm{C}(30)-\mathrm{C}(20) & 111.0(2) \\ \mathrm{C}(31)-\mathrm{C}(30)-\mathrm{H}(30) & 107.3 \\ \mathrm{C}(32)-\mathrm{C}(30)-\mathrm{H}(30) & 107.3 \\ \mathrm{C}(20)-\mathrm{C}(30)-\mathrm{H}(30) & 107.3 \\ \mathrm{C}(30)-\mathrm{C}(31)-\mathrm{H}(31 \mathrm{~A}) & 109.5 \\ \mathrm{C}(30)-\mathrm{C}(31)-\mathrm{H}(31 \mathrm{~B}) & 109.5\end{array}$

$\mathrm{H}(31 \mathrm{~A})-\mathrm{C}(31)-\mathrm{H}(31 \mathrm{~B}) \quad 109.5$

C(30)-C(31)-H(31C) 109.5

$\mathrm{H}(31 \mathrm{~A})-\mathrm{C}(31)-\mathrm{H}(31 \mathrm{C}) \quad 109.5$

$\mathrm{H}(31 \mathrm{~B})-\mathrm{C}(31)-\mathrm{H}(31 \mathrm{C}) \quad 109.5$

$\mathrm{O}(2)-\mathrm{C}(32)-\mathrm{C}(30) \quad 109.5(2)$

$\mathrm{O}(2)-\mathrm{C}(32)-\mathrm{C}(33) \quad 107.8(2)$

$\mathrm{C}(30)-\mathrm{C}(32)-\mathrm{C}(33) \quad 114.4(2)$

$\mathrm{O}(2)-\mathrm{C}(32)-\mathrm{H}(32) \quad 108.3$

$\mathrm{C}(30)-\mathrm{C}(32)-\mathrm{H}(32) \quad 108.3$

$\mathrm{C}(33)-\mathrm{C}(32)-\mathrm{H}(32) \quad 108.3$

$\mathrm{C}(32)-\mathrm{C}(33)-\mathrm{C}(38) \quad 109.8(2)$

$\mathrm{C}(32)-\mathrm{C}(33)-\mathrm{C}(34) \quad 112.9(2)$

$\mathrm{C}(38)-\mathrm{C}(33)-\mathrm{C}(34) \quad 110.2(3)$

$\mathrm{C}(32)-\mathrm{C}(33)-\mathrm{H}(33) \quad 107.9$

$\mathrm{C}(38)-\mathrm{C}(33)-\mathrm{H}(33) \quad 107.9$

$\mathrm{C}(34)-\mathrm{C}(33)-\mathrm{H}(33) \quad 107.9$

$\mathrm{C}(35)-\mathrm{C}(34)-\mathrm{C}(33) \quad 112.0(3)$

C(35)-C(34)-H(34A) 109.2

C(33)-C(34)-H(34A) 109.2

C(35)-C(34)-H(34B) 109.2

C(33)-C(34)-H(34B) 109.2

$\mathrm{H}(34 \mathrm{~A})-\mathrm{C}(34)-\mathrm{H}(34 \mathrm{~B}) \quad 107.9$

$\mathrm{C}(36)-\mathrm{C}(35)-\mathrm{C}(34) \quad 111.3(3)$

C(36)-C(35)-H(35A) 109.4

C(34)-C(35)-H(35A) 109.4

C(36)-C(35)-H(35B) 109.4

C(34)-C(35)-H(35B) 109.4

$\mathrm{H}(35 \mathrm{~A})-\mathrm{C}(35)-\mathrm{H}(35 \mathrm{~B}) \quad 108.0$

$\mathrm{C}(35)-\mathrm{C}(36)-\mathrm{C}(37) \quad 110.4(3)$

$\mathrm{C}(35)-\mathrm{C}(36)-\mathrm{H}(36 \mathrm{~A}) 109.6$

C(37)-C(36)-H(36A) 109.6

C(35)-C(36)-H(36B) 109.6

C(37)-C(36)-H(36B) 109.6

$\mathrm{H}(36 \mathrm{~A})-\mathrm{C}(36)-\mathrm{H}(36 \mathrm{~B}) \quad 108.1$

$\mathrm{C}(38)-\mathrm{C}(37)-\mathrm{C}(36) \quad 111.0(3)$

C(38)-C(37)-H(37A) 109.4 
C(36)-C(37)-H(37A) 109.4

$\mathrm{C}(38)-\mathrm{C}(37)-\mathrm{H}(37 \mathrm{~B}) \quad 109.4$

$\mathrm{C}(36)-\mathrm{C}(37)-\mathrm{H}(37 \mathrm{~B}) \quad 109.4$

$\mathrm{H}(37 \mathrm{~A})-\mathrm{C}(37)-\mathrm{H}(37 \mathrm{~B})$

$\mathrm{C}(37)-\mathrm{C}(38)-\mathrm{C}(33) \quad 113.1(3)$

$\mathrm{C}(37)-\mathrm{C}(38)-\mathrm{H}(38 \mathrm{~A}) \quad 109.0$

$\mathrm{C}(33)-\mathrm{C}(38)-\mathrm{H}(38 \mathrm{~A}) \quad 109.0$

$\mathrm{C}(37)-\mathrm{C}(38)-\mathrm{H}(38 \mathrm{~B}) \quad 109.0$

$\mathrm{C}(33)-\mathrm{C}(38)-\mathrm{H}(38 \mathrm{~B}) \quad 109.0$

$\mathrm{H}(38 \mathrm{~A})-\mathrm{C}(38)-\mathrm{H}(38 \mathrm{~B})$

$\mathrm{C}(10)-\mathrm{N}(1)-\mathrm{C}(9) \quad 108.1(2)$

$\mathrm{C}(10)-\mathrm{N}(2)-\mathrm{C}(8) \quad 108.3(2)$

$\mathrm{C}(10)-\mathrm{N}(2)-\mathrm{C}(1) \quad 137.7(3)$
$\mathrm{C}(8)-\mathrm{N}(2)-\mathrm{C}(1) \quad 114.0(2)$

$\mathrm{C}(29)-\mathrm{N}(3)-\mathrm{C}(28) \quad 109.2(3)$

$\mathrm{C}(29)-\mathrm{N}(3)-\mathrm{H}(3 \mathrm{~A}) \quad 125.4$

$\mathrm{C}(28)-\mathrm{N}(3)-\mathrm{H}(3 \mathrm{~A}) \quad 125.4$

C(29)-N(4)-C(27) 108.8(3)

$\mathrm{C}(29)-\mathrm{N}(4)-\mathrm{C}(20) \quad 137.4(3)$

$\mathrm{C}(27)-\mathrm{N}(4)-\mathrm{C}(20) \quad 113.8(2)$

$\mathrm{C}(13)-\mathrm{O}(1)-\mathrm{H}(1 \mathrm{~A}) \quad 109.5$

$\mathrm{C}(32)-\mathrm{O}(2)-\mathrm{H}(2) \quad 109.5$

$\mathrm{H}(3 \mathrm{X})-\mathrm{O}(3)-\mathrm{H}(3 \mathrm{Y}) \quad 107.7$

$\mathrm{H}(4 \mathrm{X})-\mathrm{O}(4)-\mathrm{H}(4 \mathrm{Y}) \quad 109.3$

$\mathrm{H}(5 \mathrm{X})-\mathrm{O}(5)-\mathrm{H}(5 \mathrm{Y}) \quad 107.7$

Symmetry transformations used to generate equivalent atoms: 
Table 4. Anisotropic displacement parameters ( $\AA 2$ x 103)for G03081798.1-1. The anisotropic displacement factor exponent takes the form: $-2 \square 2\left[\mathrm{~h} 2 \mathrm{a}^{*} 2 \mathrm{U} 11+\ldots+2 \mathrm{~h} \mathrm{k} \mathrm{a*} \mathrm{b}^{*} \mathrm{U} 12\right.$ ]

\begin{tabular}{|c|c|c|c|c|c|c|}
\hline & U11 & U22 & U33 & U23 & U13 & U12 \\
\hline $\mathrm{C}(1)$ & $24(1)$ & $28(2)$ & $21(1)$ & $-6(1)$ & $-6(1)$ & $-2(1)$ \\
\hline$C(2)$ & $21(1)$ & $29(2)$ & $20(1)$ & $-5(1)$ & $-2(1)$ & $-2(1)$ \\
\hline$C(3)$ & $24(1)$ & $32(2)$ & $26(2)$ & $-8(1)$ & $-5(1)$ & $-3(1)$ \\
\hline$C(4)$ & $24(1)$ & $37(2)$ & $31(2)$ & $-5(1)$ & $-9(1)$ & $0(1)$ \\
\hline$C(5)$ & $26(2)$ & $29(2)$ & $33(2)$ & $-3(1)$ & $-7(1)$ & $2(1)$ \\
\hline$C(6)$ & $29(2)$ & $27(2)$ & $29(2)$ & $-5(1)$ & $-6(1)$ & $-1(1)$ \\
\hline$C(7)$ & $22(1)$ & $30(2)$ & $20(1)$ & $-5(1)$ & $-5(1)$ & $-2(1)$ \\
\hline$C(8)$ & $23(1)$ & $26(2)$ & $22(1)$ & $-7(1)$ & $-4(1)$ & $0(1)$ \\
\hline C(9) & $26(1)$ & $30(2)$ & $25(2)$ & $-9(1)$ & $-5(1)$ & $0(1)$ \\
\hline$C(10)$ & $25(1)$ & $33(2)$ & $19(1)$ & $-6(1)$ & $-4(1)$ & $2(1)$ \\
\hline $\mathrm{C}(11)$ & $25(1)$ & $27(2)$ & $22(1)$ & $-8(1)$ & $-5(1)$ & $0(1)$ \\
\hline$C(12)$ & $27(1)$ & $33(2)$ & $24(1)$ & $-10(1)$ & $0(1)$ & $-7(1)$ \\
\hline$C(13)$ & $24(1)$ & $26(2)$ & $22(1)$ & $-6(1)$ & $-5(1)$ & $-2(1)$ \\
\hline$C(14)$ & $29(2)$ & $26(2)$ & $20(1)$ & $-7(1)$ & $-8(1)$ & $0(1)$ \\
\hline$C(15)$ & $30(2)$ & $33(2)$ & $23(2)$ & $-9(1)$ & $-7(1)$ & $4(1)$ \\
\hline$C(16)$ & $34(2)$ & $38(2)$ & $31(2)$ & $-14(2)$ & $-4(1)$ & $4(1)$ \\
\hline$C(17)$ & $44(2)$ & $34(2)$ & $30(2)$ & $-14(2)$ & $-4(1)$ & $0(2)$ \\
\hline$C(18)$ & $45(2)$ & $35(2)$ & $28(2)$ & $-12(2)$ & $-11(1)$ & $-2(2)$ \\
\hline$C(19)$ & $36(2)$ & $32(2)$ & $27(2)$ & $-10(1)$ & $-13(1)$ & $0(1)$ \\
\hline $\mathrm{C}(20)$ & $23(1)$ & $27(2)$ & $22(1)$ & $-7(1)$ & $-5(1)$ & $6(1)$ \\
\hline $\mathrm{C}(21)$ & $20(1)$ & $33(2)$ & $19(1)$ & $-8(1)$ & $-3(1)$ & $3(1)$ \\
\hline$C(22)$ & $24(1)$ & $36(2)$ & $26(2)$ & $-9(1)$ & $-7(1)$ & $9(1)$ \\
\hline$C(23)$ & $24(2)$ & $42(2)$ & $32(2)$ & $-14(2)$ & $-10(1)$ & $8(1)$ \\
\hline$C(24)$ & $28(2)$ & $42(2)$ & $33(2)$ & $-21(2)$ & $-8(1)$ & $5(1)$ \\
\hline$C(25)$ & $28(2)$ & $33(2)$ & $31(2)$ & $-14(1)$ & $-9(1)$ & $7(1)$ \\
\hline$C(26)$ & $23(1)$ & $31(2)$ & $20(1)$ & $-8(1)$ & $-3(1)$ & $4(1)$ \\
\hline $\mathrm{C}(27)$ & $24(1)$ & $27(2)$ & $20(1)$ & $-4(1)$ & $-3(1)$ & $1(1)$ \\
\hline $\mathrm{C}(28)$ & $26(1)$ & $31(2)$ & $24(2)$ & $-5(1)$ & $-6(1)$ & $1(1)$ \\
\hline $\mathrm{C}(29)$ & $26(1)$ & $33(2)$ & $22(1)$ & $-7(1)$ & $-6(1)$ & $0(1)$ \\
\hline$C(30)$ & $25(1)$ & $29(2)$ & $21(1)$ & $-6(1)$ & $-3(1)$ & $4(1)$ \\
\hline $\mathrm{C}(31)$ & $29(2)$ & $29(2)$ & $27(2)$ & $-4(1)$ & $2(1)$ & $11(1)$ \\
\hline$C(32)$ & $27(1)$ & $30(2)$ & $21(1)$ & $-9(1)$ & $-4(1)$ & $7(1)$ \\
\hline$C(33)$ & $27(2)$ & $31(2)$ & $19(1)$ & $-6(1)$ & $-5(1)$ & $6(1)$ \\
\hline$C(34)$ & $31(2)$ & $32(2)$ & $25(2)$ & $-4(1)$ & $-5(1)$ & $0(1)$ \\
\hline$C(35)$ & $34(2)$ & $36(2)$ & $28(2)$ & $-5(1)$ & $-2(1)$ & $-3(1)$ \\
\hline$C(36)$ & $43(2)$ & $29(2)$ & $30(2)$ & $-5(1)$ & $0(1)$ & $2(1)$ \\
\hline$C(37)$ & $46(2)$ & $33(2)$ & $27(2)$ & $-5(1)$ & $-11(1)$ & $11(2)$ \\
\hline $\mathrm{C}(38)$ & $33(2)$ & $32(2)$ & $30(2)$ & $-8(1)$ & $-9(1)$ & $7(1)$ \\
\hline $\mathrm{N}(1)$ & $25(1)$ & $33(1)$ & $24(1)$ & $-7(1)$ & $-7(1)$ & $2(1)$ \\
\hline $\mathrm{N}(2)$ & $24(1)$ & $29(1)$ & $21(1)$ & $-8(1)$ & $-6(1)$ & $0(1)$ \\
\hline $\mathrm{N}(3)$ & $24(1)$ & $34(2)$ & $23(1)$ & $-5(1)$ & $-7(1)$ & $0(1)$ \\
\hline
\end{tabular}




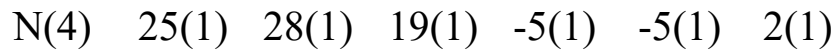

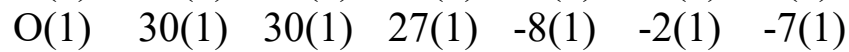

$\mathrm{O}(2) \quad 48(1) \quad 31(1) \quad 28(1) \quad-12(1) \quad 6(1) \quad 8(1)$

$\begin{array}{lllllll}\mathrm{O}(3) & 56(2) & 75(2) & 75(2) & -39(2) & -18(2) & 10(2)\end{array}$

$\begin{array}{lllllll}\mathrm{O}(4) & 43(2) & 59(2) & 62(2) & 31(2) & 7(1) & -11(1)\end{array}$

$\begin{array}{lllllll}\mathrm{O}(5) & 34(1) & 60(2) & 66(2) & -13(2) & 4(1) & 9(1)\end{array}$

$\mathrm{Cl}(1) \quad 38(1) \quad 68(1) \quad 69(1) \quad-31(1) \quad 2(1) \quad-8(1)$ 
Table 5. Hydrogen coordinates ( x 104) and isotropic displacement parameters ( $\AA 2$ x 103) for Compound 8.

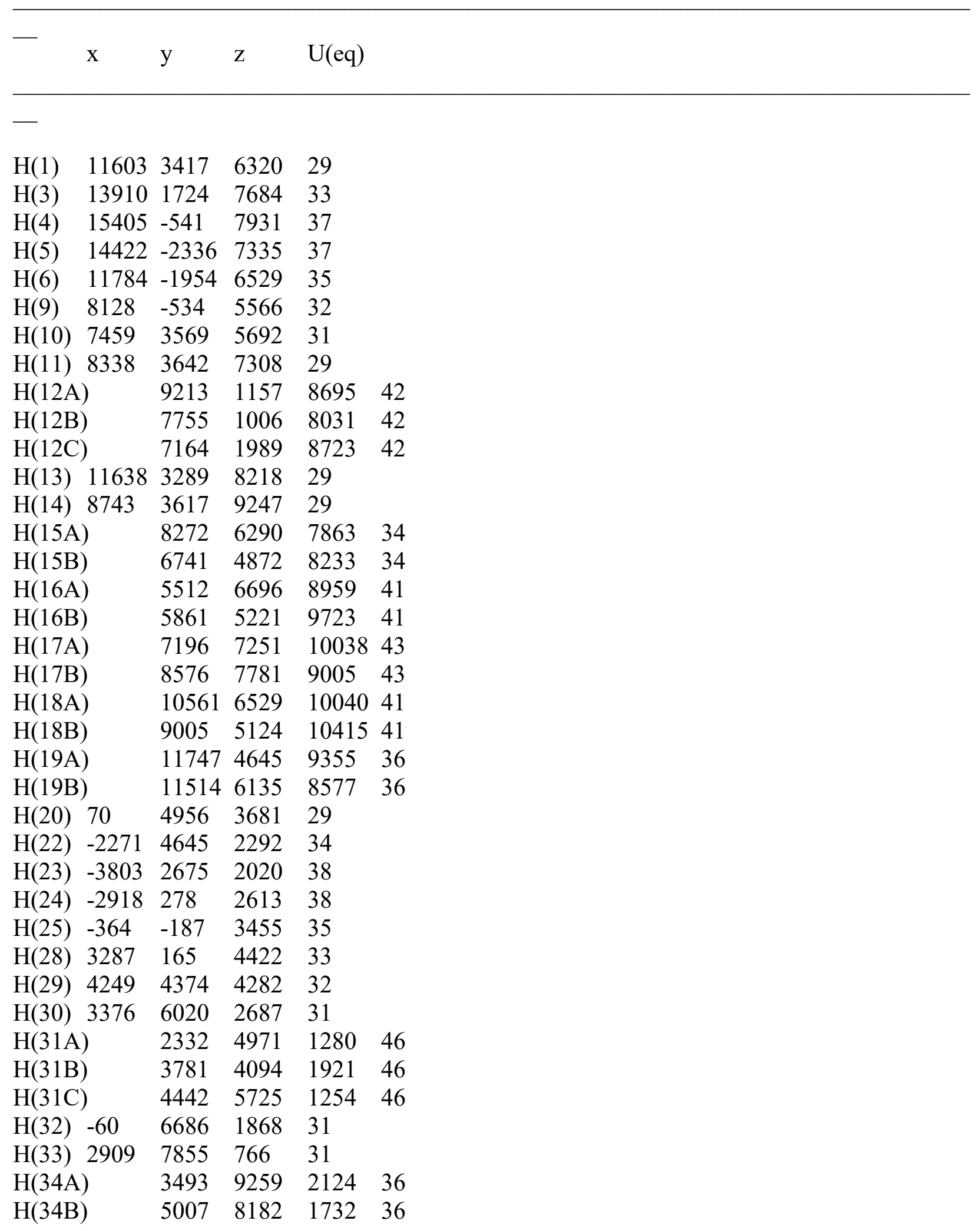




\begin{tabular}{|c|c|c|c|}
\hline $\mathrm{H}(35 \mathrm{~A})$ & 6196 & 10680 & 997 \\
\hline $\mathrm{H}(35 \mathrm{~B})$ & 5800 & 9919 & 241 \\
\hline $\mathrm{H}(36 \mathrm{~A})$ & 4445 & 12247 & -49 \\
\hline $\mathrm{H}(36 \mathrm{~B})$ & 3111 & 11813 & 994 \\
\hline $\mathrm{H}(37 \mathrm{~A})$ & 1066 & 11549 & -20 \\
\hline $\mathrm{H}(37 \mathrm{~B})$ & 2607 & 10482 & -409 \\
\hline $\mathrm{H}(38 \mathrm{~A})$ & -99 & 9035 & 676 \\
\hline $\mathrm{H}(38 \mathrm{~B})$ & 178 & 9802 & 1445 \\
\hline $\mathrm{H}(3 \mathrm{~A}) 5233$ & 1921 & 4850 & 33 \\
\hline $\mathrm{H}(1 \mathrm{~A}) 10958$ & 5519 & 6849 & 45 \\
\hline $\mathrm{H}(2) \quad-893$ & 7246 & 3087 & 56 \\
\hline$H(3 X) 1691$ & 7720 & 3771 & 77 \\
\hline H(3Y) 3246 & 7742 & 4209 & 77 \\
\hline$H(4 X)-1575$ & 6110 & 5816 & 82 \\
\hline H(4Y) 272 & 6849 & 5428 & 82 \\
\hline$H(5 X)-5520$ & 5496 & 6466 & 68 \\
\hline $\mathrm{H}(5 \mathrm{Y})-4232$ & 6299 & 5662 & 68 \\
\hline
\end{tabular}




\section{Experimental data for SC-XRD on Compound 9}

$\mathrm{X}$-ray quality crystals were grown from a saturated 1,2-dichloroethane/ethanol/methanol solution followed by the slow vapor diffusion of heptane to deposit the crystal diffracted. A colorless rod $0.070 \times 0.030 \times 0.030 \mathrm{~mm}$ in size was mounted on a Cryoloop with Paratone oil. Data were collected in a nitrogen gas stream at 90(2) $\mathrm{K}$ using phi and omega scans. Crystal-to-detector distance was $40 \mathrm{~mm}$ and exposure time was 0.05 seconds per frame using a scan width of $0.5^{\circ}$. Data collection was $100.0 \%$ complete to $67.000^{\circ}$ in theta. A total of 13517 reflections were collected covering the indices, $-13<=h<=13,-5<=k<=5,-17<=l<=17.2595$ reflections were found to be symmetry independent, with an $R_{\text {int }}$ of 0.0389 . Indexing and unit cell refinement indicated a primitive, monoclinic lattice. The space group was found to be P 21 (No. 4). The data were integrated and scaled using CrysAlisPro 1.171.40.35a. Solution by iterative methods (SHELXT-2014) produced a complete heavy-atom phasing model. All non-hydrogen atoms were refined anisotropically by full-matrix least-squares (SHELXL-2018). All hydrogen atoms were placed using a riding model. Their positions were constrained relative to their parent atom using the appropriate HFIX command in SHELXL-2018. Absolute stereochemistry was unambiguously determined to be $R$ at $\mathrm{C} 11$ and $\mathrm{C} 12$, and $S$ at $\mathrm{C} 1$, respectively. 
Table 1. Crystal data and structure refinement for Compound 9.

X-ray ID Compound 9

Sample/notebook ID Compound 9

Empirical formula

C16 H18 N2 O

Formula weight 254.32

Temperature 90(2) K

Wavelength $1.54184 \AA$

Crystal system Monoclinic

Space group P 21

Unit cell dimensions $\mathrm{a}=10.7972(5) \AA \quad$ alpha $=90^{\circ}$.

$$
\begin{array}{ll}
\mathrm{b}=4.73210(10) \AA & \text { beta }=111.019(5)^{\circ} . \\
\mathrm{c}=13.9575(6) \AA & \text { gamma }=90^{\circ} .
\end{array}
$$

Volume $\quad 665.69(5) \AA 3$

Z 2

Density (calculated) $1.269 \mathrm{Mg} / \mathrm{m} 3$

Absorption coefficient $\quad 0.631 \mathrm{~mm}-1$

$\mathrm{F}(000) 272$

Crystal size $\quad 0.070 \times 0.030 \times 0.030 \mathrm{~mm} 3$

Theta range for data collection $\quad 3.392$ to $74.741^{\circ}$.

Index ranges $-13<=\mathrm{h}<=13,-5<=\mathrm{k}<=5,-17<=1<=17$

Reflections collected 13517

Independent reflections $2595[\mathrm{R}$ (int) $=0.0389$ ]

Completeness to theta $=67.000^{\circ} \quad 100.0 \%$

Absorption correction Gaussian

Max. and min. transmission 1.000 and 0.626

Refinement method Full-matrix least-squares on F2

Data / restraints / parameters 2595 / 1 / 174

Goodness-of-fit on F2 1.061

Final $\mathrm{R}$ indices $[\mathrm{I}>2 \operatorname{sigma}(\mathrm{I})] \mathrm{R} 1=0.0285, \mathrm{wR} 2=0.0773$

$\mathrm{R}$ indices (all data) $\mathrm{R} 1=0.0289, \mathrm{wR} 2=0.0777$

Absolute structure parameter -0.12(13)

Extinction coefficient $0.0134(16)$

Largest diff. peak and hole 0.189 and -0.144 e. $\AA-3$ 
Table 2. Atomic coordinates ( $\mathrm{x} 104)$ and equivalent isotropic displacement parameters ( $\AA 2 \mathrm{x}$ 103)

for Compound 9. $\mathrm{U}(\mathrm{eq})$ is defined as one third of the trace of the orthogonalized Uij tensor.

\begin{tabular}{lllll}
\hline & \multicolumn{3}{c}{$\mathrm{U}(\mathrm{eq})$} \\
& $\mathrm{x}$ & $\mathrm{z}$ & \\
$\overline{\mathrm{C}}(1)$ & $6466(2)$ & $3958(4)$ & $2951(1)$ & $16(1)$ \\
$\mathrm{C}(2)$ & $7645(2)$ & $5334(3)$ & $2776(1)$ & $17(1)$ \\
$\mathrm{C}(3)$ & $8123(2)$ & $4925(4)$ & $1990(1)$ & $20(1)$ \\
$\mathrm{C}(4)$ & $9233(2)$ & $6446(4)$ & $1996(1)$ & $24(1)$ \\
$\mathrm{C}(5)$ & $9862(2)$ & $8336(4)$ & $2782(1)$ & $26(1)$ \\
$\mathrm{C}(6)$ & $9407(2)$ & $8725(4)$ & $3586(1)$ & $22(1)$ \\
$\mathrm{C}(7)$ & $8306(2)$ & $7202(4)$ & $3581(1)$ & $17(1)$ \\
$\mathrm{C}(8)$ & $7688(2)$ & $6954(4)$ & $4349(1)$ & $17(1)$ \\
$\mathrm{C}(9)$ & $7746(2)$ & $7692(4)$ & $5315(1)$ & $19(1)$ \\
$\mathrm{C}(10)$ & $6236(2)$ & $4447(4)$ & $4766(1)$ & $18(1)$ \\
$\mathrm{C}(11)$ & $5099(2)$ & $4986(4)$ & $2199(1)$ & $15(1)$ \\
$\mathrm{C}(12)$ & $3981(2)$ & $4199(3)$ & $2586(1)$ & $16(1)$ \\
$\mathrm{C}(13)$ & $2617(2)$ & $4988(4)$ & $1819(1)$ & $19(1)$ \\
$\mathrm{C}(14)$ & $2362(2)$ & $3777(4)$ & $748(1) 21(1)$ \\
$\mathrm{C}(15)$ & $3465(2)$ & $4720(4)$ & $372(1) 20(1)$ \\
$\mathrm{C}(16)$ & $4825(2)$ & $3804(4)$ & $1118(1)$ & $18(1)$ \\
$\mathrm{N}(1)$ & $6839(1)$ & $6092(3)$ & $5569(1)$ & $20(1)$ \\
$\mathrm{N}(2)$ & $6713(1)$ & $4925(3)$ & $4011(1)$ & $16(1)$ \\
$\mathrm{O}(1)$ & $4075(1)$ & $1245(3)$ & $2802(1)$ & $19(1)$ \\
& & &
\end{tabular}


Table 3. Bond lengths $[\AA]$ and angles $\left[^{\circ}\right]$ for Compound 9.

\begin{tabular}{|c|c|c|c|c|}
\hline $\mathrm{C}(1)-\mathrm{N}(2)$ & $1.4785(19)$ & $\mathrm{C}(10)-\mathrm{N}(2)$ & \multicolumn{2}{|c|}{$1.348(2)$} \\
\hline$C(1)-C(2)$ & $1.525(2)$ & $\mathrm{C}(10)-\mathrm{H}(10)$ & \multicolumn{2}{|c|}{0.9500} \\
\hline$C(1)-C(11)$ & $1.551(2)$ & $C(11)-C(12)$ & \multicolumn{2}{|c|}{$1.534(2)$} \\
\hline $\mathrm{C}(1)-\mathrm{H}(1)$ & 1.0000 & $C(11)-C(16)$ & \multicolumn{2}{|c|}{$1.535(2)$} \\
\hline$C(2)-C(3)$ & $1.384(2)$ & $\mathrm{C}(11)-\mathrm{H}(11)$ & \multicolumn{2}{|c|}{1.0000} \\
\hline$C(2)-C(7)$ & $1.407(2)$ & $\mathrm{C}(12)-\mathrm{O}(1)$ & \multicolumn{2}{|c|}{$1.426(2)$} \\
\hline $\mathrm{C}(3)-\mathrm{C}(4)$ & $1.395(2)$ & $\mathrm{C}(12)-\mathrm{C}(13)$ & \multicolumn{2}{|c|}{$1.524(2)$} \\
\hline $\mathrm{C}(3)-\mathrm{H}(3)$ & 0.9500 & $\mathrm{C}(12)-\mathrm{H}(12)$ & \multicolumn{2}{|c|}{1.0000} \\
\hline$C(4)-C(5)$ & $1.389(3)$ & $C(13)-C(14)$ & \multicolumn{2}{|c|}{$1.530(2)$} \\
\hline $\mathrm{C}(4)-\mathrm{H}(4)$ & 0.9500 & $\mathrm{C}(13)-\mathrm{H}(13 \mathrm{~A})$ & & 0.9900 \\
\hline$C(5)-C(6)$ & $1.391(3)$ & $\mathrm{C}(13)-\mathrm{H}(13 \mathrm{~B})$ & \multicolumn{2}{|c|}{0.9900} \\
\hline $\mathrm{C}(5)-\mathrm{H}(5)$ & 0.9500 & $C(14)-C(15)$ & \multicolumn{2}{|c|}{$1.530(2)$} \\
\hline$C(6)-C(7)$ & $1.388(3)$ & $\mathrm{C}(14)-\mathrm{H}(14 \mathrm{~A})$ & & 0.9900 \\
\hline $\mathrm{C}(6)-\mathrm{H}(6)$ & & $\mathrm{C}(14)-\mathrm{H}(14 \mathrm{~B})$ & 0.9900 & \\
\hline$C(7)-C(8)$ & & $\mathrm{C}(15)-\mathrm{C}(16)$ & 1.528( & \\
\hline $\mathrm{C}(8)-\mathrm{C}(9)$ & & $\mathrm{C}(15)-\mathrm{H}(15 \mathrm{~A})$ & & 0.9900 \\
\hline $\mathrm{C}(8)-\mathrm{N}(2)$ & & $\mathrm{C}(15)-\mathrm{H}(15 \mathrm{~B})$ & 0.9900 & \\
\hline $\mathrm{C}(9)-\mathrm{N}(1)$ & & $\mathrm{C}(16)-\mathrm{H}(16 \mathrm{~A})$ & & 0.9900 \\
\hline $\mathrm{C}(9)-\mathrm{H}(9)$ & & $\mathrm{C}(16)-\mathrm{H}(16 \mathrm{~B})$ & 0.9900 & \\
\hline $\mathrm{C}(10)-\mathrm{N}(1)$ & & $\mathrm{O}(1)-\mathrm{H}(1 \mathrm{~A})$ & 0.8400 & \\
\hline $\mathrm{N}(2)-\mathrm{C}(1)-\mathrm{C}(2)$ & $99.61(12)$ & $\mathrm{C}(2)-\mathrm{C}(7)-\mathrm{C}(8)$ & & $107.59(14)$ \\
\hline $\mathrm{N}(2)-\mathrm{C}(1)-\mathrm{C}(11)$ & $111.45(13)$ & $\mathrm{C}(9)-\mathrm{C}(8)-\mathrm{N}(2)$ & & $105.92(14)$ \\
\hline $\mathrm{C}(2)-\mathrm{C}(1)-\mathrm{C}(11)$ & $113.86(13)$ & $\mathrm{C}(9)-\mathrm{C}(8)-\mathrm{C}(7)$ & & $146.20(16)$ \\
\hline $\mathrm{N}(2)-\mathrm{C}(1)-\mathrm{H}(1)$ & 110.5 & $\mathrm{~N}(2)-\mathrm{C}(8)-\mathrm{C}(7)$ & & $107.43(13)$ \\
\hline $\mathrm{C}(2)-\mathrm{C}(1)-\mathrm{H}(1)$ & 110.5 & $\mathrm{C}(8)-\mathrm{C}(9)-\mathrm{N}(1)$ & & $109.03(15)$ \\
\hline $\mathrm{C}(11)-\mathrm{C}(1)-\mathrm{H}(1)$ & 110.5 & $\mathrm{C}(8)-\mathrm{C}(9)-\mathrm{H}(9)$ & & 125.5 \\
\hline $\mathrm{C}(3)-\mathrm{C}(2)-\mathrm{C}(7)$ & $119.67(15)$ & $\mathrm{N}(1)-\mathrm{C}(9)-\mathrm{H}(9$ & & 125.5 \\
\hline $\mathrm{C}(3)-\mathrm{C}(2)-\mathrm{C}(1)$ & $129.59(15)$ & $\mathrm{N}(1)-\mathrm{C}(10)-\mathrm{N}($ & & $110.67(14)$ \\
\hline$C(7)-C(2)-C(1)$ & $110.71(14)$ & $\mathrm{N}(1)-\mathrm{C}(10)-\mathrm{H}($ & (10) & 124.7 \\
\hline $\mathrm{C}(2)-\mathrm{C}(3)-\mathrm{C}(4)$ & $119.14(16)$ & $\mathrm{N}(2)-\mathrm{C}(10)-\mathrm{H}($ & (10) & 124.7 \\
\hline $\mathrm{C}(2)-\mathrm{C}(3)-\mathrm{H}(3)$ & 120.4 & $C(12)-C(11)-C$ & (16) & $110.99(13)$ \\
\hline $\mathrm{C}(4)-\mathrm{C}(3)-\mathrm{H}(3)$ & 120.4 & $C(12)-C(11)-C$ & C(1) & $111.36(12)$ \\
\hline $\mathrm{C}(5)-\mathrm{C}(4)-\mathrm{C}(3)$ & $120.83(16)$ & $C(16)-C(11)-C$ & $C(1)$ & $110.58(13)$ \\
\hline $\mathrm{C}(5)-\mathrm{C}(4)-\mathrm{H}(4)$ & 119.6 & $\mathrm{C}(12)-\mathrm{C}(11)-\mathrm{H}$ & $\mathrm{H}(11)$ & 107.9 \\
\hline $\mathrm{C}(3)-\mathrm{C}(4)-\mathrm{H}(4)$ & 119.6 & $\mathrm{C}(16)-\mathrm{C}(11)-\mathrm{H}$ & $\mathrm{H}(11)$ & 107.9 \\
\hline$C(4)-C(5)-C(6)$ & $120.57(17)$ & $\mathrm{C}(1)-\mathrm{C}(11)-\mathrm{H}($ & (11) & 107.9 \\
\hline $\mathrm{C}(4)-\mathrm{C}(5)-\mathrm{H}(5)$ & 119.7 & $\mathrm{O}(1)-\mathrm{C}(12)-\mathrm{C}($ & (13) & $111.45(14)$ \\
\hline $\mathrm{C}(6)-\mathrm{C}(5)-\mathrm{H}(5)$ & 119.7 & $\mathrm{O}(1)-\mathrm{C}(12)-\mathrm{C}($ & (11) & 107.93(13) \\
\hline$C(7)-C(6)-C(5)$ & $118.51(17)$ & $\mathrm{C}(13)-\mathrm{C}(12)-\mathrm{C}$ & C(11) & $112.22(13)$ \\
\hline $\mathrm{C}(7)-\mathrm{C}(6)-\mathrm{H}(6)$ & 120.7 & $\mathrm{O}(1)-\mathrm{C}(12)-\mathrm{H}($ & (12) & 108.4 \\
\hline $\mathrm{C}(5)-\mathrm{C}(6)-\mathrm{H}(6)$ & 120.7 & $\mathrm{C}(13)-\mathrm{C}(12)-\mathrm{H}$ & (12) & 108.4 \\
\hline$C(6)-C(7)-C(2)$ & $121.25(16)$ & $\mathrm{C}(11)-\mathrm{C}(12)-\mathrm{H}$ & $\mathrm{H}(12)$ & 108.4 \\
\hline $\mathrm{C}(6)-\mathrm{C}(7)-\mathrm{C}(8)$ & $130.97(16)$ & $\mathrm{C}(12)-\mathrm{C}(13)-\mathrm{C}$ & $C(14)$ & $112.58(14)$ \\
\hline
\end{tabular}


$\mathrm{C}(12)-\mathrm{C}(13)-\mathrm{H}(13 \mathrm{~A}) \quad 109.1$

$\mathrm{C}(14)-\mathrm{C}(13)-\mathrm{H}(13 \mathrm{~A}) \quad 109.1$

$\mathrm{C}(12)-\mathrm{C}(13)-\mathrm{H}(13 \mathrm{~B}) \quad 109.1$

C(14)-C(13)-H(13B) 109.1

$\mathrm{H}(13 \mathrm{~A})-\mathrm{C}(13)-\mathrm{H}(13 \mathrm{~B}) \quad 107.8$

$\mathrm{C}(15)-\mathrm{C}(14)-\mathrm{C}(13) \quad 109.67(14)$

$\mathrm{C}(15)-\mathrm{C}(14)-\mathrm{H}(14 \mathrm{~A}) \quad 109.7$

C(13)-C(14)-H(14A) 109.7

C(15)-C(14)-H(14B) 109.7

C(13)-C(14)-H(14B) 109.7

$\mathrm{H}(14 \mathrm{~A})-\mathrm{C}(14)-\mathrm{H}(14 \mathrm{~B}) \quad 108.2$

$\mathrm{C}(16)-\mathrm{C}(15)-\mathrm{C}(14) \quad 111.04(13)$

$\mathrm{C}(16)-\mathrm{C}(15)-\mathrm{H}(15 \mathrm{~A}) \quad 109.4$

C(14)-C(15)-H(15A) 109.4
$\mathrm{C}(16)-\mathrm{C}(15)-\mathrm{H}(15 \mathrm{~B}) \quad 109.4$

$\mathrm{C}(14)-\mathrm{C}(15)-\mathrm{H}(15 \mathrm{~B}) \quad 109.4$

$\mathrm{H}(15 \mathrm{~A})-\mathrm{C}(15)-\mathrm{H}(15 \mathrm{~B}) \quad 108.0$

$\mathrm{C}(15)-\mathrm{C}(16)-\mathrm{C}(11) \quad 111.48(13)$

$\mathrm{C}(15)-\mathrm{C}(16)-\mathrm{H}(16 \mathrm{~A}) \quad 109.3$

$\mathrm{C}(11)-\mathrm{C}(16)-\mathrm{H}(16 \mathrm{~A}) \quad 109.3$

$\mathrm{C}(15)-\mathrm{C}(16)-\mathrm{H}(16 \mathrm{~B}) \quad 109.3$

$\mathrm{C}(11)-\mathrm{C}(16)-\mathrm{H}(16 \mathrm{~B}) \quad 109.3$

$\mathrm{H}(16 \mathrm{~A})-\mathrm{C}(16)-\mathrm{H}(16 \mathrm{~B}) \quad 108.0$

$\mathrm{C}(10)-\mathrm{N}(1)-\mathrm{C}(9) \quad 106.41(13)$

$\mathrm{C}(10)-\mathrm{N}(2)-\mathrm{C}(8) \quad 107.94(13)$

$\mathrm{C}(10)-\mathrm{N}(2)-\mathrm{C}(1) \quad 138.46(14)$

$\mathrm{C}(8)-\mathrm{N}(2)-\mathrm{C}(1) \quad 113.58(13)$

C(12)-O(1)-H(1A) 109.5

Symmetry transformations used to generate equivalent atoms: 
Table 4. Anisotropic displacement parameters ( $\AA 2 \times 103)$ for Compound 9. The anisotropic displacement factor exponent takes the form: $-2 \square 2\left[\mathrm{~h} 2 \mathrm{a} * 2 \mathrm{U} 11+\ldots+2 \mathrm{~h} \mathrm{k} \mathrm{a} \mathrm{b}^{*} \mathrm{U} 12\right.$ ]

\begin{tabular}{lllllll}
\hline & $\mathrm{U} 11$ & $\mathrm{U} 22$ & $\mathrm{U} 33$ & $\mathrm{U} 23$ & $\mathrm{U} 13$ & $\mathrm{U} 12$ \\
\hline $\mathrm{C}(1)$ & $18(1)$ & $15(1)$ & $13(1)$ & $-2(1)$ & $6(1)$ & $0(1)$ \\
$\mathrm{C}(2)$ & $15(1)$ & $17(1)$ & $18(1)$ & $4(1)$ & $4(1)$ & $3(1)$ \\
$\mathrm{C}(3)$ & $17(1)$ & $24(1)$ & $18(1)$ & $2(1)$ & $5(1)$ & $4(1)$ \\
$\mathrm{C}(4)$ & $18(1)$ & $35(1)$ & $20(1)$ & $7(1)$ & $8(1)$ & $7(1)$ \\
$\mathrm{C}(5)$ & $16(1)$ & $32(1)$ & $29(1)$ & $7(1)$ & $8(1)$ & $0(1)$ \\
$\mathrm{C}(6)$ & $17(1)$ & $23(1)$ & $24(1)$ & $0(1)$ & $4(1)$ & $-1(1)$ \\
$\mathrm{C}(7)$ & $14(1)$ & $18(1)$ & $18(1)$ & $2(1)$ & $4(1)$ & $4(1)$ \\
$\mathrm{C}(8)$ & $14(1)$ & $16(1)$ & $18(1)$ & $0(1)$ & $3(1)$ & $2(1)$ \\
$\mathrm{C}(9)$ & $17(1)$ & $20(1)$ & $18(1)$ & $-4(1)$ & $3(1)$ & $1(1)$ \\
$\mathrm{C}(10)$ & $18(1)$ & $21(1)$ & $17(1)$ & $2(1)$ & $6(1)$ & $3(1)$ \\
$\mathrm{C}(11)$ & $16(1)$ & $14(1)$ & $15(1)$ & $0(1)$ & $6(1)$ & $1(1)$ \\
$\mathrm{C}(12)$ & $19(1)$ & $14(1)$ & $15(1)$ & $-1(1)$ & $7(1)$ & $0(1)$ \\
$\mathrm{C}(13)$ & $17(1)$ & $20(1)$ & $21(1)$ & $0(1)$ & $7(1)$ & $1(1)$ \\
$\mathrm{C}(14)$ & $18(1)$ & $24(1)$ & $18(1)$ & $0(1)$ & $2(1)$ & $-2(1)$ \\
$\mathrm{C}(15)$ & $22(1)$ & $23(1)$ & $15(1)$ & $0(1)$ & $5(1)$ & $-1(1)$ \\
$\mathrm{C}(16)$ & $19(1)$ & $20(1)$ & $15(1)$ & $-1(1)$ & $7(1)$ & $0(1)$ \\
$\mathrm{N}(1)$ & $18(1)$ & $24(1)$ & $17(1)$ & $-2(1)$ & $6(1)$ & $3(1)$ \\
$\mathrm{N}(2)$ & $17(1)$ & $16(1)$ & $14(1)$ & $-1(1)$ & $5(1)$ & $1(1)$ \\
$\mathrm{O}(1)$ & $24(1)$ & $15(1)$ & $19(1)$ & $2(1)$ & $10(1)$ & $-2(1)$ \\
& & & & & & \\
\hline
\end{tabular}


Table 5. Hydrogen coordinates ( x 104) and isotropic displacement parameters ( $\AA 2$ x 103) for Compound 9.

\begin{tabular}{lllll}
\hline & $\mathrm{x}$ & $\mathrm{y}$ & $\mathrm{z}$ & $\mathrm{U}(\mathrm{eq})$ \\
\hline
\end{tabular}

$\begin{array}{llllll}\mathrm{H}(1) & 6529 & 1853 & 2928 & 19 & \\ \mathrm{H}(3) & 7701 & 3627 & 1452 & 24 & \\ \mathrm{H}(4) & 9563 & 6186 & 1456 & 29 & \\ \mathrm{H}(5) & 10610 & 9372 & 2769 & 31 & \\ \mathrm{H}(6) & 9839 & 10005 & 4128 & 26 & \\ \mathrm{H}(9) & 8318 & 9080 & 5741 & 23 & \\ \mathrm{H}(10) & 5562 & 3117 & 4729 & 22 & \\ \mathrm{H}(11) & 5130 & 7094 & 2160 & 18 & \\ \mathrm{H}(12) & 4126 & 5245 & 3240 & 19 & \\ \mathrm{H}(13 \mathrm{~A}) & 2541 & 7072 & 1772 & 23 \\ \mathrm{H}(13 \mathrm{~B}) & 1928 & 4278 & 2072 & 23 \\ \mathrm{H}(14 \mathrm{~A}) & 2337 & 1688 & 773 & 25 \\ \mathrm{H}(14 \mathrm{~B}) & 1493 & 4448 & 267 & 25 \\ \mathrm{H}(15 \mathrm{~A}) & 3310 & 3887 & -312 & 24 \\ \mathrm{H}(15 \mathrm{~B}) & 3444 & 6803 & 300 & 24 \\ \mathrm{H}(16 \mathrm{~A}) & 5520 & 4476 & 864 & 21 \\ \mathrm{H}(16 \mathrm{~B}) & 4867 & 1714 & 1150 & 21 \\ \mathrm{H}(1 \mathrm{~A}) & 3749 & 899 & 3253 & 28 & \end{array}$




\section{Experimental data for SC-XRD on Compound ent-12}

$\mathrm{X}$-ray quality crystals were grown from a saturated 1,2-dichloroethane/ethanol/methanol solution followed by the slow vapor diffusion of diisopropyl ether to deposit the crystal diffracted. A colorless prism $0.070 \times 0.060 \times 0.050 \mathrm{~mm}$ in size was mounted on a Cryoloop with Paratone oil. Data were collected in a nitrogen gas stream at 100(2) K using and scans. Crystal-to-detector distance was $60 \mathrm{~mm}$ and exposure time was 1 seconds per frame using a scan width of $2.0^{\circ}$. Data collection was $99.4 \%$ complete to $67.000^{\circ}$ in theta. A total of 10940 reflections were collected covering the indices, $-6<=h<=6,-7<=k<=8,-35<=l<=35.2032$ reflections were found to be symmetry independent, with an $\mathrm{R}_{\text {int }}$ of 0.0552 . Indexing and unit cell refinement indicated a primitive, orthorhombic lattice. The space group was found to be P 212121 (No. 19). The data were integrated using the Bruker SAINT software program and scaled using the SADABS software program. Solution by iterative methods (SHELXT-2014) produced a complete heavyatom phasing model consistent with the proposed structure. All non-hydrogen atoms were refined anisotropically by full-matrix least-squares (SHELXL-2014). All hydrogen atoms were placed using a riding model. Their positions were constrained relative to their parent atom using the appropriate HFIX command in SHELXL-2014. Absolute stereochemistry was unambiguously determined to be $R$ at $\mathrm{C} 1$ and $\mathrm{C} 11$, and $S$ at $\mathrm{C} 12$, respectively. 
Table 1. Crystal data and structure refinement for Compound ent-12.

X-ray ID Compound ent-12

Sample/notebook ID Compound ent-12

Empirical formula $\mathrm{C} 14 \mathrm{H} 14 \mathrm{~N} 2 \mathrm{O}$

Formula weight $\quad 226.27$

Temperature $100(2) \mathrm{K}$

Wavelength $1.54178 \AA$

Crystal system Orthorhombic

Space group P 212121

Unit cell dimensions $\mathrm{a}=5.7576(3) \AA \quad$ alpha $=90^{\circ}$.

$$
\begin{array}{ll}
\mathrm{b}=6.6825(4) \AA & \text { beta }=90^{\circ} . \\
\mathrm{c}=29.3671(16) \AA & \text { gamma }=90^{\circ} .
\end{array}
$$

Volume $\quad 1129.90(11) \AA 3$

Z 4

Density (calculated) $1.330 \mathrm{Mg} / \mathrm{m} 3$

Absorption coefficient $\quad 0.679 \mathrm{~mm}-1$

$\mathrm{F}(000) 480$

Crystal size $\quad 0.070 \times 0.060 \times 0.050 \mathrm{~mm} 3$

Theta range for data collection $\quad 3.009$ to $68.154^{\circ}$.

Index ranges $-6<=\mathrm{h}<=6,-7<=\mathrm{k}<=8,-35<=\mathrm{l}<=35$

Reflections collected 10940

Independent reflections $2032[\mathrm{R}$ (int) $=0.0552]$

Completeness to theta $=67.000^{\circ} \quad 99.4 \%$

Absorption correction Semi-empirical from equivalents

Max. and min. transmission 0.929 and 0.825

Refinement method Full-matrix least-squares on F2

Data / restraints / parameters 2032 / 0 / 155

Goodness-of-fit on F2 1.050

Final $\mathrm{R}$ indices $[\mathrm{I}>2 \operatorname{sigma}(\mathrm{I})] \mathrm{R} 1=0.0331, \mathrm{wR} 2=0.0821$

$\mathrm{R}$ indices (all data) $\quad \mathrm{R} 1=0.0339, \mathrm{wR} 2=0.0825$

Absolute structure parameter 0.01(14)

Extinction coefficient $\mathrm{n} / \mathrm{a}$

Largest diff. peak and hole $\quad 0.180$ and -0.191 e. $\AA-3$ 
Table 2. Atomic coordinates ( $\mathrm{x} 104)$ and equivalent isotropic displacement parameters ( $\AA 2 \mathrm{x}$ 103)

for Compound ent-12. U(eq) is defined as one third of the trace of the orthogonalized Uij tensor.

\begin{tabular}{|c|c|c|c|c|}
\hline \multirow{2}{*}{$\begin{array}{l}- \\
\overline{\mathrm{C}(1)}\end{array}$} & \multirow{2}{*}{$\begin{array}{l}\mathrm{x} \quad \mathrm{y} \\
2015(4)\end{array}$} & \multirow{2}{*}{$\begin{array}{l}z \\
6641(3)\end{array}$} & \multicolumn{2}{|l|}{$\mathrm{U}(\mathrm{eq})$} \\
\hline & & & $3695(1)$ & $18(1)$ \\
\hline$C(2)$ & $3751(3)$ & $6491(3)$ & $4085(1)$ & $19(1)$ \\
\hline$C(3)$ & $5351(4)$ & $7902(3)$ & $4229(1)$ & $21(1)$ \\
\hline$C(4)$ & $6920(4)$ & $7381(3)$ & $4571(1)$ & $23(1)$ \\
\hline$C(5)$ & $6887(4)$ & $5463(3)$ & $4760(1)$ & $24(1)$ \\
\hline$C(6)$ & $5269(4)$ & $4052(3)$ & $4622(1)$ & $23(1)$ \\
\hline$C(7)$ & $3680(4)$ & $4579(3)$ & $4286(1)$ & $19(1)$ \\
\hline $\mathrm{C}(8)$ & $1795(3)$ & $3469(3)$ & $4070(1)$ & $19(1)$ \\
\hline $\mathrm{C}(9)$ & $533(4) 1739(3)$ & & $4055(1)$ & \\
\hline$C(10)$ & $-890(3) 3678(3)$ & & $3538(1) \quad 2$ & \\
\hline $\mathrm{C}(11)$ & $3212(3)$ & $6863(3)$ & $3234(1)$ & $19(1)$ \\
\hline$C(12)$ & $4403(3)$ & $8876(3)$ & $3123(1)$ & $21(1)$ \\
\hline$C(13)$ & $3512(4)$ & $8680(3)$ & $2629(1)$ & $22(1)$ \\
\hline$C(14)$ & $1732(4)$ & $7109(3)$ & $2796(1)$ & $22(1)$ \\
\hline $\mathrm{N}(1)$ & $-1146(3)$ & $1876(3)$ & $3721(1)$ & $25(1)$ \\
\hline $\mathrm{N}(2)$ & $856(3) 4687(2)$ & & $3739(1)$ & \\
\hline $\mathrm{O}(1)$ & $6829(2)$ & $8937(2)$ & $3176(1)$ & $26(1)$ \\
\hline
\end{tabular}


Table 3. Bond lengths $[\AA]$ and angles $\left[^{\circ}\right]$ for Compound ent- 12 .

\begin{tabular}{|c|c|c|c|c|}
\hline$\overline{\mathrm{C}(1)-\mathrm{N}(2)}$ & $1.472(2)$ & $\mathrm{C}(9)-\mathrm{N}(1)$ & \multicolumn{2}{|c|}{$1.381(3)$} \\
\hline $\mathrm{C}(1)-\mathrm{C}(2)$ & $1.523(3)$ & $\mathrm{C}(9)-\mathrm{H}(9)$ & \multicolumn{2}{|c|}{0.9500} \\
\hline$C(1)-C(11)$ & $1.528(2)$ & $\mathrm{C}(10)-\mathrm{N}(1)$ & \multicolumn{2}{|c|}{$1.327(3)$} \\
\hline $\mathrm{C}(1)-\mathrm{H}(1)$ & 1.0000 & $\mathrm{C}(10)-\mathrm{N}(2)$ & \multicolumn{2}{|c|}{$1.347(2)$} \\
\hline$C(2)-C(3)$ & $1.385(3)$ & $\mathrm{C}(10)-\mathrm{H}(10)$ & \multicolumn{2}{|c|}{0.9500} \\
\hline $\mathrm{C}(2)-\mathrm{C}(7)$ & $1.408(3)$ & $\mathrm{C}(11)-\mathrm{C}(12)$ & \multicolumn{2}{|c|}{$1.545(3)$} \\
\hline$C(3)-C(4)$ & $1.394(3)$ & $C(11)-C(14)$ & \multicolumn{2}{|c|}{$1.551(2)$} \\
\hline $\mathrm{C}(3)-\mathrm{H}(3)$ & 0.9500 & $\mathrm{C}(11)-\mathrm{H}(11)$ & \multicolumn{2}{|c|}{1.0000} \\
\hline$C(4)-C(5)$ & $1.398(3)$ & $\mathrm{C}(12)-\mathrm{O}(1)$ & \multicolumn{2}{|c|}{$1.406(2)$} \\
\hline $\mathrm{C}(4)-\mathrm{H}(4)$ & 0.9500 & $C(12)-C(13)$ & \multicolumn{2}{|c|}{$1.545(2)$} \\
\hline$C(5)-C(6)$ & $1.387(3)$ & $\mathrm{C}(12)-\mathrm{H}(12)$ & \multicolumn{2}{|c|}{1.0000} \\
\hline $\mathrm{C}(5)-\mathrm{H}(5)$ & 0.9500 & C(13)-C(14) & \multicolumn{2}{|c|}{$1.547(3)$} \\
\hline$C(6)-C(7)$ & $1.390(3)$ & $\mathrm{C}(13)-\mathrm{H}(13 \mathrm{~A})$ & & 0.9900 \\
\hline $\mathrm{C}(6)-\mathrm{H}(6)$ & & $\mathrm{C}(13)-\mathrm{H}(13 \mathrm{~B})$ & 0.9900 & \\
\hline $\mathrm{C}(7)-\mathrm{C}(8)$ & & $\mathrm{C}(14)-\mathrm{H}(14 \mathrm{~A})$ & & 0.9900 \\
\hline $\mathrm{C}(8)-\mathrm{C}(9)$ & & $\mathrm{C}(14)-\mathrm{H}(14 \mathrm{~B})$ & 0.9900 & \\
\hline $\mathrm{C}(8)-\mathrm{N}(2)$ & & $\mathrm{O}(1)-\mathrm{H}(1 \mathrm{~A})$ & 0.8400 & \\
\hline $\mathrm{N}(2)-\mathrm{C}(1)-\mathrm{C}(2)$ & $99.96(14)$ & $\mathrm{N}(2)-\mathrm{C}(8)-\mathrm{C}(7$ & & $107.37(16)$ \\
\hline $\mathrm{N}(2)-\mathrm{C}(1)-\mathrm{C}(11)$ & $111.59(15)$ & $\mathrm{C}(8)-\mathrm{C}(9)-\mathrm{N}(1$ & & $109.78(17)$ \\
\hline $\mathrm{C}(2)-\mathrm{C}(1)-\mathrm{C}(11)$ & $112.15(16)$ & $\mathrm{C}(8)-\mathrm{C}(9)-\mathrm{H}(9$ & & 125.1 \\
\hline $\mathrm{N}(2)-\mathrm{C}(1)-\mathrm{H}(1)$ & 110.9 & $\mathrm{~N}(1)-\mathrm{C}(9)-\mathrm{H}(9$ & & 125.1 \\
\hline $\mathrm{C}(2)-\mathrm{C}(1)-\mathrm{H}(1)$ & 110.9 & $\mathrm{~N}(1)-\mathrm{C}(10)-\mathrm{N}($ & & $111.05(17)$ \\
\hline $\mathrm{C}(11)-\mathrm{C}(1)-\mathrm{H}(1)$ & 110.9 & $\mathrm{~N}(1)-\mathrm{C}(10)-\mathrm{H}($ & (10) & 124.5 \\
\hline $\mathrm{C}(3)-\mathrm{C}(2)-\mathrm{C}(7)$ & $120.57(18)$ & $\mathrm{N}(2)-\mathrm{C}(10)-\mathrm{H}($ & (10) & 124.5 \\
\hline $\mathrm{C}(3)-\mathrm{C}(2)-\mathrm{C}(1)$ & $128.43(17)$ & $\mathrm{C}(1)-\mathrm{C}(11)-\mathrm{C}($ & (12) & $118.06(15)$ \\
\hline$C(7)-C(2)-C(1)$ & $110.89(16)$ & $C(1)-C(11)-C($ & (14) & $119.87(16)$ \\
\hline $\mathrm{C}(2)-\mathrm{C}(3)-\mathrm{C}(4)$ & $118.77(18)$ & $C(12)-C(11)-C$ & (14) & $88.73(14)$ \\
\hline $\mathrm{C}(2)-\mathrm{C}(3)-\mathrm{H}(3)$ & 120.6 & $\mathrm{C}(1)-\mathrm{C}(11)-\mathrm{H}($ & (11) & 109.5 \\
\hline $\mathrm{C}(4)-\mathrm{C}(3)-\mathrm{H}(3)$ & 120.6 & $\mathrm{C}(12)-\mathrm{C}(11)-\mathrm{H}$ & $\mathrm{H}(11)$ & 109.5 \\
\hline$C(3)-C(4)-C(5)$ & $120.45(19)$ & $\mathrm{C}(14)-\mathrm{C}(11)-\mathrm{H}$ & $\mathrm{H}(11)$ & 109.5 \\
\hline $\mathrm{C}(3)-\mathrm{C}(4)-\mathrm{H}(4)$ & 119.8 & $\mathrm{O}(1)-\mathrm{C}(12)-\mathrm{C}($ & (11) & $116.32(18)$ \\
\hline $\mathrm{C}(5)-\mathrm{C}(4)-\mathrm{H}(4)$ & 119.8 & $\mathrm{O}(1)-\mathrm{C}(12)-\mathrm{C}($ & (13) & $115.81(16)$ \\
\hline$C(6)-C(5)-C(4)$ & $121.08(19)$ & $C(11)-C(12)-C$ & (13) & $88.59(15)$ \\
\hline $\mathrm{C}(6)-\mathrm{C}(5)-\mathrm{H}(5)$ & 119.5 & $\mathrm{O}(1)-\mathrm{C}(12)-\mathrm{H}($ & (12) & 111.4 \\
\hline $\mathrm{C}(4)-\mathrm{C}(5)-\mathrm{H}(5)$ & 119.5 & $\mathrm{C}(11)-\mathrm{C}(12)-\mathrm{H}$ & $\mathrm{H}(12)$ & 111.4 \\
\hline$C(5)-C(6)-C(7)$ & $118.53(19)$ & $\mathrm{C}(13)-\mathrm{C}(12)-\mathrm{H}$ & $\mathrm{H}(12)$ & 111.4 \\
\hline $\mathrm{C}(5)-\mathrm{C}(6)-\mathrm{H}(6)$ & 120.7 & $C(12)-C(13)-C$ & C(14) & $88.88(14)$ \\
\hline $\mathrm{C}(7)-\mathrm{C}(6)-\mathrm{H}(6)$ & 120.7 & $C(12)-C(13)-H$ & $\mathrm{H}(13 \mathrm{~A})$ & 113.8 \\
\hline$C(6)-C(7)-C(2)$ & $120.57(18)$ & $\mathrm{C}(14)-\mathrm{C}(13)-\mathrm{H}$ & $\mathrm{H}(13 \mathrm{~A})$ & 113.8 \\
\hline$C(6)-C(7)-C(8)$ & $131.98(18)$ & $\mathrm{C}(12)-\mathrm{C}(13)-\mathrm{H}$ & $\mathrm{H}(13 \mathrm{~B})$ & 113.8 \\
\hline $\mathrm{C}(2)-\mathrm{C}(7)-\mathrm{C}(8)$ & $107.43(17)$ & $\mathrm{C}(14)-\mathrm{C}(13)-\mathrm{H}$ & $\mathrm{H}(13 \mathrm{~B})$ & 113.8 \\
\hline $\mathrm{C}(9)-\mathrm{C}(8)-\mathrm{N}(2)$ & 105.61(17) & $\mathrm{H}(13 \mathrm{~A})-\mathrm{C}(13)$ & $-H(13 B$ & 3) $\quad 111.1$ \\
\hline $\mathrm{C}(9)-\mathrm{C}(8)-\mathrm{C}(7)$ & $147.02(19)$ & $C(13)-C(14)-C$ & (11) & $88.30(14)$ \\
\hline
\end{tabular}


$\mathrm{C}(13)-\mathrm{C}(14)-\mathrm{H}(14 \mathrm{~A}) 113.9$

$\mathrm{C}(11)-\mathrm{C}(14)-\mathrm{H}(14 \mathrm{~A}) 113.9$

$\mathrm{C}(13)-\mathrm{C}(14)-\mathrm{H}(14 \mathrm{~B}) 113.9$

$\mathrm{C}(11)-\mathrm{C}(14)-\mathrm{H}(14 \mathrm{~B}) \quad 113.9$

$\mathrm{H}(14 \mathrm{~A})-\mathrm{C}(14)-\mathrm{H}(14 \mathrm{~B})$
$\mathrm{C}(10)-\mathrm{N}(1)-\mathrm{C}(9)$

$\mathrm{C}(10)-\mathrm{N}(2)-\mathrm{C}(8)$

$\mathrm{C}(10)-\mathrm{N}(2)-\mathrm{C}(1)$

$\mathrm{C}(8)-\mathrm{N}(2)-\mathrm{C}(1)$

$\mathrm{C}(12)-\mathrm{O}(1)-\mathrm{H}(1 \mathrm{~A})$
$105.70(17)$

$107.85(16)$

$138.07(17)$

$114.07(15)$

109.5

Symmetry transformations used to generate equivalent atoms: 
Table 4. Anisotropic displacement parameters ( $\AA 2 \mathrm{x} 103)$ for Compound ent-12. The anisotropic displacement factor exponent takes the form: $-2 \square 2\left[\mathrm{~h} 2 \mathrm{a}^{*} 2 \mathrm{U} 11+\ldots+2 \mathrm{~h} \mathrm{k} \mathrm{a} * \mathrm{~b} * \mathrm{U} 12\right.$ ]

\begin{tabular}{lllllll}
\hline & $\mathrm{U} 11$ & $\mathrm{U} 22$ & $\mathrm{U} 33$ & $\mathrm{U} 23$ & $\mathrm{U} 13$ & $\mathrm{U} 12$ \\
\hline $\mathrm{C}(1)$ & $19(1)$ & $17(1)$ & $20(1)$ & $-2(1)$ & $1(1)$ & $-2(1)$ \\
$\mathrm{C}(2)$ & $19(1)$ & $21(1)$ & $16(1)$ & $-2(1)$ & $3(1)$ & $0(1)$ \\
$\mathrm{C}(3)$ & $23(1)$ & $21(1)$ & $17(1)$ & $-3(1)$ & $3(1)$ & $-4(1)$ \\
$\mathrm{C}(4)$ & $21(1)$ & $30(1)$ & $18(1)$ & $-5(1)$ & $1(1)$ & $-5(1)$ \\
$\mathrm{C}(5)$ & $23(1)$ & $32(1)$ & $16(1)$ & $-2(1)$ & $-2(1)$ & $1(1)$ \\
$\mathrm{C}(6)$ & $26(1)$ & $24(1)$ & $18(1)$ & $1(1)$ & $0(1)$ & $2(1)$ \\
$\mathrm{C}(7)$ & $22(1)$ & $21(1)$ & $16(1)$ & $-4(1)$ & $2(1)$ & $0(1)$ \\
$\mathrm{C}(8)$ & $21(1)$ & $21(1)$ & $16(1)$ & $-2(1)$ & $1(1)$ & $1(1)$ \\
$\mathrm{C}(9)$ & $25(1)$ & $23(1)$ & $20(1)$ & $0(1)$ & $2(1)$ & $-2(1)$ \\
$\mathrm{C}(10)$ & $20(1)$ & $28(1)$ & $20(1)$ & $-1(1)$ & $-2(1)$ & $-3(1)$ \\
$\mathrm{C}(11)$ & $18(1)$ & $21(1)$ & $17(1)$ & $-2(1)$ & $-1(1)$ & $1(1)$ \\
$\mathrm{C}(12)$ & $18(1)$ & $23(1)$ & $20(1)$ & $-2(1)$ & $0(1)$ & $-1(1)$ \\
$\mathrm{C}(13)$ & $23(1)$ & $24(1)$ & $19(1)$ & $2(1)$ & $-1(1)$ & $0(1)$ \\
$\mathrm{C}(14)$ & $20(1)$ & $29(1)$ & $17(1)$ & $-1(1)$ & $-2(1)$ & $-1(1)$ \\
$\mathrm{N}(1)$ & $24(1)$ & $27(1)$ & $23(1)$ & $-3(1)$ & $0(1)$ & $-6(1)$ \\
$\mathrm{N}(2)$ & $19(1)$ & $21(1)$ & $17(1)$ & $-1(1)$ & $0(1)$ & $-1(1)$ \\
$\mathrm{O}(1)$ & $20(1)$ & $34(1)$ & $26(1)$ & $-7(1)$ & $1(1)$ & $-6(1)$ \\
& & & & & & \\
\hline
\end{tabular}


Table 5. Hydrogen coordinates ( x 104) and isotropic displacement parameters ( $\AA 2$ x 103) for Compound ent-12.

\begin{tabular}{|c|c|c|c|c|c|}
\hline- & $\mathrm{x}$ & $\mathrm{y}$ & z & $\mathrm{U}(\mathrm{eq})$ & \\
\hline - & & & & & \\
\hline $\mathrm{H}(1)$ & 893 & 7760 & 3748 & 22 & \\
\hline $\mathrm{H}(3)$ & 5379 & 9201 & 4098 & 25 & \\
\hline $\mathrm{H}(4)$ & 8018 & 8337 & 4676 & 28 & \\
\hline $\mathrm{H}(5)$ & 7992 & 5120 & 4988 & 28 & \\
\hline $\mathrm{H}(6)$ & 5246 & 2753 & 4753 & 27 & \\
\hline $\mathrm{H}(9)$ & 775 & 611 & 4246 & 27 & \\
\hline $\mathrm{H}(10)$ & -1815 & 4188 & 3296 & 27 & \\
\hline $\mathrm{H}(11)$ & 4347 & 5745 & 3191 & 23 & \\
\hline $\mathrm{H}(12)$ & 3635 & 10013 & 3286 & 25 & \\
\hline $\mathrm{H}(13 \mathrm{~A}$ & & 4679 & 8141 & 2414 & 27 \\
\hline $\mathrm{H}(13 \mathrm{~B}$ & & 2794 & 9918 & 2509 & 27 \\
\hline $\mathrm{H}(14 \mathrm{~A}$ & & 1663 & 5890 & 2604 & 26 \\
\hline $\mathrm{H}(14 \mathrm{~B}$ & & 160 & 7658 & 2851 & 26 \\
\hline $\mathrm{H}(1 \mathrm{~A})$ & 7183 & 9839 & 3363 & 40 & \\
\hline
\end{tabular}




\section{Experimental data for SC-XRD on Compound ent-13}

X-ray quality crystals were grown from a saturated 1,2-dichloroethane/ethanol/methanol solution followed by the slow vapor diffusion of heptane to deposit the crystal diffracted. A colorless prism $0.120 \times 0.100 \times 0.100 \mathrm{~mm}$ in size was mounted on a Cryoloop with Paratone oil. Data were collected in a nitrogen gas stream at 100(2) K using and scans. Crystal-to-detector distance was $60 \mathrm{~mm}$ and exposure time was 1 seconds per frame using a scan width of $2.0^{\circ}$. Data collection was $99.4 \%$ complete to $67.000^{\circ}$ in theta. A total of 13431 reflections were collected covering the indices, $-6<=h<=6,-11<=k<=11,-28<=l<=25.2340$ reflections were found to be symmetry independent, with an $\mathrm{R}_{\text {int }}$ of 0.0385 . Indexing and unit cell refinement indicated a primitive, orthorhombic lattice. The space group was found to be P 212121 (No. 19). The data were integrated using the Bruker SAINT software program and scaled using the SADABS software program. Solution by iterative methods (SHELXT-2014) produced a complete heavyatom phasing model consistent with the proposed structure. All non-hydrogen atoms were refined anisotropically by full-matrix least-squares (SHELXL-2014). All hydrogen atoms were placed using a riding model. Their positions were constrained relative to their parent atom using the appropriate HFIX command in SHELXL-2014. Absolute stereochemistry was unambiguously determined to be $R$ at $\mathrm{C} 1, \mathrm{C} 11$, and $\mathrm{C} 12$, respectively. 
Table 1. Crystal data and structure refinement for Compound ent-13.

X-ray ID Compound ent-13

Sample/notebook ID Compound ent-13

Empirical formula $\mathrm{C} 15 \mathrm{H} 16 \mathrm{~N} 2 \mathrm{O} 2$

Formula weight $\quad 256.30$

Temperature $100(2) \mathrm{K}$

Wavelength $1.54178 \AA$

Crystal system Orthorhombic

Space group P 212121

Unit cell dimensions $\mathrm{a}=5.7224(3) \AA \quad$ alpha $=90^{\circ}$.

$$
\begin{array}{ll}
\mathrm{b}=9.4414(5) \AA & \text { beta }=90^{\circ} . \\
\mathrm{c}=23.8273(12) \AA & \text { gamma }=90^{\circ} .
\end{array}
$$

Volume $\quad 1287.33(12) \AA 3$

Z 4

Density (calculated) $1.322 \mathrm{Mg} / \mathrm{m} 3$

Absorption coefficient $\quad 0.719 \mathrm{~mm}-1$

$\mathrm{F}(000) 544$

Crystal size $\quad 0.120 \times 0.100 \times 0.100 \mathrm{~mm} 3$

Theta range for data collection $\quad 5.039$ to $68.456^{\circ}$.

Index ranges $-6<=\mathrm{h}<=6,-11<=\mathrm{k}<=11,-28<=\mathrm{l}<=25$

Reflections collected 13431

Independent reflections $2340[\mathrm{R}$ (int) $=0.0385]$

Completeness to theta $=67.000^{\circ} \quad 99.4 \%$

Absorption correction Semi-empirical from equivalents

Max. and min. transmission 0.929 and 0.802

Refinement method Full-matrix least-squares on F2

Data / restraints / parameters 2340 / 0 / 173

Goodness-of-fit on F2 1.086

Final $\mathrm{R}$ indices $[\mathrm{I}>2 \operatorname{sigma}(\mathrm{I})] \mathrm{R} 1=0.0304, \mathrm{wR} 2=0.0778$

$\mathrm{R}$ indices (all data) $\mathrm{R} 1=0.0306, \mathrm{wR} 2=0.0780$

Absolute structure parameter 0.05(7)

Extinction coefficient $\mathrm{n} / \mathrm{a}$

Largest diff. peak and hole $\quad 0.183$ and -0.198 e. $\AA-3$ 
Table 2. Atomic coordinates ( $\mathrm{x} 104)$ and equivalent isotropic displacement parameters ( $\AA 2 \mathrm{x}$ 103)

for Compound ent-13. U(eq) is defined as one third of the trace of the orthogonalized Uij tensor.

\begin{tabular}{|c|c|c|c|c|}
\hline- & $\mathrm{X}$ & \multicolumn{3}{|l|}{$\mathrm{U}(\mathrm{eq})$} \\
\hline $\mathrm{C}(1)$ & $4134(3)$ & $4455(2)$ & $4020(1)$ & $16(1)$ \\
\hline $\mathrm{C}(2)$ & $2873(3)$ & $3063(2)$ & $3921(1)$ & $16(1)$ \\
\hline$C(3)$ & $3435(3)$ & $2008(2)$ & $3543(1)$ & $18(1)$ \\
\hline$C(4)$ & $1978(4)$ & $822(2) 3503(1)$ & ) $\quad 21(1)$ & \\
\hline$C(5)$ & $-11(4) 718(2)$ & $3836(1)$ & $21(1)$ & \\
\hline$C(6)$ & $-590(3) 1784(2)$ & 2) $\quad 4217(1)$ & $19(1)$ & \\
\hline$C(7)$ & $864(3) 2953(2)$ & $4258(1)$ & $16(1)$ & \\
\hline $\mathrm{C}(8)$ & $794(3) 4207(2)$ & $4619(1)$ & $15(1)$ & \\
\hline $\mathrm{C}(9)$ & $-214(3) 4848(2)$ & $5073(1)$ & $18(1)$ & \\
\hline$C(10)$ & $2805(4)$ & $6107(2)$ & $4849(1)$ & $19(1)$ \\
\hline $\mathrm{C}(11)$ & 4231(3) & $5402(2)$ & $3494(1)$ & $16(1)$ \\
\hline$C(12)$ & $5024(3)$ & $6915(2)$ & $3619(1)$ & $17(1)$ \\
\hline$C(13)$ & $5354(4)$ & $7695(2)$ & $3064(1)$ & 21(1) \\
\hline$C(14)$ & $2298(4)$ & $6397(2)$ & $2642(1)$ & $23(1)$ \\
\hline$C(15)$ & 1922(3) & $5517(2)$ & $3168(1)$ & $19(1)$ \\
\hline $\mathrm{N}(1)$ & 1073(3) & $6038(2)$ & $5215(1)$ & $19(1)$ \\
\hline $\mathrm{N}(2)$ & $2696(3)$ & $5031(2)$ & $4480(1)$ & $16(1)$ \\
\hline $\mathrm{O}(1)$ & $3222(3)$ & $7777(1)$ & $2757(1)$ & $23(1)$ \\
\hline $\mathrm{O}(2)$ & $7136(2)$ & $6934(1)$ & $3930(1)$ & $21(1)$ \\
\hline
\end{tabular}


Table 3. Bond lengths $[\AA]$ and angles $\left[^{\circ}\right]$ for Compound ent- 13 .

\begin{tabular}{|c|c|c|c|c|}
\hline $\mathrm{C}(1)-\mathrm{N}(2)$ & $1.474(2)$ & $\mathrm{C}(10)-\mathrm{N}(1)$ & \multicolumn{2}{|c|}{$1.322(2)$} \\
\hline$C(1)-C(2)$ & $1.518(2)$ & $\mathrm{C}(10)-\mathrm{N}(2)$ & \multicolumn{2}{|c|}{$1.346(2)$} \\
\hline$C(1)-C(11)$ & $1.540(2)$ & $\mathrm{C}(10)-\mathrm{H}(10)$ & \multicolumn{2}{|c|}{0.9500} \\
\hline $\mathrm{C}(1)-\mathrm{H}(1)$ & 1.0000 & $\mathrm{C}(11)-\mathrm{C}(12)$ & \multicolumn{2}{|c|}{$1.529(2)$} \\
\hline$C(2)-C(3)$ & $1.381(3)$ & $C(11)-C(15)$ & \multicolumn{2}{|c|}{$1.537(2)$} \\
\hline$C(2)-C(7)$ & $1.406(2)$ & $\mathrm{C}(11)-\mathrm{H}(11)$ & \multicolumn{2}{|c|}{1.0000} \\
\hline $\mathrm{C}(3)-\mathrm{C}(4)$ & $1.399(3)$ & $\mathrm{C}(12)-\mathrm{O}(2)$ & \multicolumn{2}{|c|}{$1.418(2)$} \\
\hline $\mathrm{C}(3)-\mathrm{H}(3)$ & 0.9500 & $C(12)-C(13)$ & \multicolumn{2}{|c|}{$1.526(3)$} \\
\hline$C(4)-C(5)$ & $1.391(3)$ & $\mathrm{C}(12)-\mathrm{H}(12)$ & \multicolumn{2}{|c|}{1.0000} \\
\hline $\mathrm{C}(4)-\mathrm{H}(4)$ & 0.9500 & $\mathrm{C}(13)-\mathrm{O}(1)$ & \multicolumn{2}{|c|}{$1.424(2)$} \\
\hline$C(5)-C(6)$ & $1.395(3)$ & $\mathrm{C}(13)-\mathrm{H}(13 \mathrm{~A})$ & & 0.9900 \\
\hline $\mathrm{C}(5)-\mathrm{H}(5)$ & 0.9500 & $\mathrm{C}(13)-\mathrm{H}(13 \mathrm{~B})$ & \multicolumn{2}{|c|}{0.9900} \\
\hline$C(6)-C(7)$ & $1.386(3)$ & $\mathrm{C}(14)-\mathrm{O}(1)$ & 1.432( & \\
\hline $\mathrm{C}(6)-\mathrm{H}(6)$ & & $\mathrm{C}(14)-\mathrm{C}(15)$ & 1.520 & \\
\hline $\mathrm{C}(7)-\mathrm{C}(8)$ & & $\mathrm{C}(14)-\mathrm{H}(14 \mathrm{~A})$ & & 0.9900 \\
\hline $\mathrm{C}(8)-\mathrm{C}(9)$ & & $\mathrm{C}(14)-\mathrm{H}(14 \mathrm{~B})$ & 0.9900 & \\
\hline $\mathrm{C}(8)-\mathrm{N}(2)$ & & $\mathrm{C}(15)-\mathrm{H}(15 \mathrm{~A})$ & & 0.9900 \\
\hline $\mathrm{C}(9)-\mathrm{N}(1)$ & & $\mathrm{C}(15)-\mathrm{H}(15 \mathrm{~B})$ & 0.9900 & \\
\hline $\mathrm{C}(9)-\mathrm{H}(9)$ & & $\mathrm{O}(2)-\mathrm{H}(2)$ & 0.8400 & \\
\hline $\mathrm{N}(2)-\mathrm{C}(1)-\mathrm{C}(2)$ & $99.79(14)$ & $\mathrm{C}(9)-\mathrm{C}(8)-\mathrm{N}(2)$ & & $105.87(16)$ \\
\hline $\mathrm{N}(2)-\mathrm{C}(1)-\mathrm{C}(11$ & $114.26(14)$ & $\mathrm{C}(9)-\mathrm{C}(8)-\mathrm{C}(7)$ & & $146.53(18)$ \\
\hline$C(2)-C(1)-C(11)$ & $113.09(14)$ & $\mathrm{N}(2)-\mathrm{C}(8)-\mathrm{C}(7)$ & & $107.10(15)$ \\
\hline $\mathrm{N}(2)-\mathrm{C}(1)-\mathrm{H}(1)$ & 109.8 & $\mathrm{C}(8)-\mathrm{C}(9)-\mathrm{N}(1)$ & & $109.15(16)$ \\
\hline $\mathrm{C}(2)-\mathrm{C}(1)-\mathrm{H}(1)$ & 109.8 & $\mathrm{C}(8)-\mathrm{C}(9)-\mathrm{H}(9$ & & 125.4 \\
\hline $\mathrm{C}(11)-\mathrm{C}(1)-\mathrm{H}(1)$ & 109.8 & $\mathrm{~N}(1)-\mathrm{C}(9)-\mathrm{H}(9$ & & 125.4 \\
\hline$C(3)-C(2)-C(7)$ & $120.64(17)$ & $\mathrm{N}(1)-\mathrm{C}(10)-\mathrm{N}($ & & $111.05(17)$ \\
\hline$C(3)-C(2)-C(1)$ & $128.02(16)$ & $\mathrm{N}(1)-\mathrm{C}(10)-\mathrm{H}($ & (10) & 124.5 \\
\hline$C(7)-C(2)-C(1)$ & $111.29(15)$ & $\mathrm{N}(2)-\mathrm{C}(10)-\mathrm{H}($ & (10) & 124.5 \\
\hline$C(2)-C(3)-C(4)$ & $118.88(17)$ & $C(12)-C(11)-C$ & (15) & $106.69(14)$ \\
\hline $\mathrm{C}(2)-\mathrm{C}(3)-\mathrm{H}(3)$ & 120.6 & $C(12)-C(11)-C$ & (1) & $113.28(14)$ \\
\hline $\mathrm{C}(4)-\mathrm{C}(3)-\mathrm{H}(3)$ & 120.6 & C(15)-C(11)-C & (1) & $114.95(14)$ \\
\hline $\mathrm{C}(5)-\mathrm{C}(4)-\mathrm{C}(3)$ & $120.34(17)$ & $\mathrm{C}(12)-\mathrm{C}(11)-\mathrm{H}$ & $\mathrm{I}(11)$ & 107.2 \\
\hline $\mathrm{C}(5)-\mathrm{C}(4)-\mathrm{H}(4)$ & 119.8 & $\mathrm{C}(15)-\mathrm{C}(11)-\mathrm{H}$ & $\mathrm{I}(11)$ & 107.2 \\
\hline $\mathrm{C}(3)-\mathrm{C}(4)-\mathrm{H}(4)$ & 119.8 & $\mathrm{C}(1)-\mathrm{C}(11)-\mathrm{H}($ & (11) & 107.2 \\
\hline$C(4)-C(5)-C(6)$ & $120.97(17)$ & $\mathrm{O}(2)-\mathrm{C}(12)-\mathrm{C}($ & (13) & $109.98(15)$ \\
\hline $\mathrm{C}(4)-\mathrm{C}(5)-\mathrm{H}(5)$ & 119.5 & $\mathrm{O}(2)-\mathrm{C}(12)-\mathrm{C}($ & (11) & $111.47(15)$ \\
\hline $\mathrm{C}(6)-\mathrm{C}(5)-\mathrm{H}(5)$ & 119.5 & $C(13)-C(12)-C$ & (11) & $108.65(15)$ \\
\hline$C(7)-C(6)-C(5)$ & $118.55(18)$ & $\mathrm{O}(2)-\mathrm{C}(12)-\mathrm{H}($ & (12) & 108.9 \\
\hline $\mathrm{C}(7)-\mathrm{C}(6)-\mathrm{H}(6)$ & 120.7 & $\mathrm{C}(13)-\mathrm{C}(12)-\mathrm{H}$ & $\mathrm{I}(12)$ & 108.9 \\
\hline $\mathrm{C}(5)-\mathrm{C}(6)-\mathrm{H}(6)$ & 120.7 & $\mathrm{C}(11)-\mathrm{C}(12)-\mathrm{H}$ & $\mathrm{I}(12)$ & 108.9 \\
\hline$C(6)-C(7)-C(2)$ & $120.61(17)$ & $\mathrm{O}(1)-\mathrm{C}(13)-\mathrm{C}($ & (12) & $111.39(15)$ \\
\hline$C(6)-C(7)-C(8)$ & $132.02(17)$ & $\mathrm{O}(1)-\mathrm{C}(13)-\mathrm{H}($ & $(13 \mathrm{~A})$ & 109.3 \\
\hline$C(2)-C(7)-C(8)$ & 107.34(16) & $\mathrm{C}(12)-\mathrm{C}(13)-\mathrm{H}$ & $\mathrm{I}(13 \mathrm{~A})$ & 109.3 \\
\hline
\end{tabular}


$\mathrm{O}(1)-\mathrm{C}(13)-\mathrm{H}(13 \mathrm{~B}) \quad 109.3$

$\mathrm{C}(12)-\mathrm{C}(13)-\mathrm{H}(13 \mathrm{~B}) \quad 109.3$

$\mathrm{H}(13 \mathrm{~A})-\mathrm{C}(13)-\mathrm{H}(13 \mathrm{~B}) \quad 108.0$

$\mathrm{O}(1)-\mathrm{C}(14)-\mathrm{C}(15) \quad 113.06(15)$

$\mathrm{O}(1)-\mathrm{C}(14)-\mathrm{H}(14 \mathrm{~A}) \quad 109.0$

$\mathrm{C}(15)-\mathrm{C}(14)-\mathrm{H}(14 \mathrm{~A}) \quad 109.0$

$\mathrm{O}(1)-\mathrm{C}(14)-\mathrm{H}(14 \mathrm{~B}) \quad 109.0$

$\mathrm{C}(15)-\mathrm{C}(14)-\mathrm{H}(14 \mathrm{~B}) \quad 109.0$

$\mathrm{H}(14 \mathrm{~A})-\mathrm{C}(14)-\mathrm{H}(14 \mathrm{~B})$

107.8

C(14)-C(15)-C(11) 109.55(15)

C(14)-C(15)-H(15A) 109.8
C(11)-C(15)-H(15A) 109.8

C(14)-C(15)-H(15B) 109.8

$\mathrm{C}(11)-\mathrm{C}(15)-\mathrm{H}(15 \mathrm{~B}) \quad 109.8$

$\mathrm{H}(15 \mathrm{~A})-\mathrm{C}(15)-\mathrm{H}(15 \mathrm{~B})$

$\mathrm{C}(10)-\mathrm{N}(1)-\mathrm{C}(9) \quad 106.10(15)$

$\mathrm{C}(10)-\mathrm{N}(2)-\mathrm{C}(8) \quad 107.82(15)$

$\mathrm{C}(10)-\mathrm{N}(2)-\mathrm{C}(1) \quad 137.60(16)$

$\mathrm{C}(8)-\mathrm{N}(2)-\mathrm{C}(1) \quad 114.28(15)$

$\mathrm{C}(13)-\mathrm{O}(1)-\mathrm{C}(14) \quad 111.43(14)$

$\mathrm{C}(12)-\mathrm{O}(2)-\mathrm{H}(2) \quad 109.5$

Symmetry transformations used to generate equivalent atoms: 
Table 4. Anisotropic displacement parameters ( $\AA 2 \mathrm{x} 103)$ for Compound ent-13. The anisotropic displacement factor exponent takes the form: $-2 \square 2\left[\mathrm{~h} 2 \mathrm{a}^{*} 2 \mathrm{U} 11+\ldots+2 \mathrm{~h} \mathrm{k} \mathrm{a} * \mathrm{~b} * \mathrm{U} 12\right.$ ]

\begin{tabular}{lllllll}
\hline & $\mathrm{U} 11$ & $\mathrm{U} 22$ & $\mathrm{U} 33$ & $\mathrm{U} 23$ & $\mathrm{U} 13$ & $\mathrm{U} 12$ \\
\hline $\mathrm{C}(1)$ & $15(1)$ & $17(1)$ & $15(1)$ & $-3(1)$ & $2(1)$ & $0(1)$ \\
$\mathrm{C}(2)$ & $17(1)$ & $16(1)$ & $15(1)$ & $1(1)$ & $-1(1)$ & $1(1)$ \\
$\mathrm{C}(3)$ & $18(1)$ & $19(1)$ & $18(1)$ & $-1(1)$ & $0(1)$ & $2(1)$ \\
$\mathrm{C}(4)$ & $28(1)$ & $17(1)$ & $19(1)$ & $-2(1)$ & $-5(1)$ & $3(1)$ \\
$\mathrm{C}(5)$ & $25(1)$ & $18(1)$ & $20(1)$ & $2(1)$ & $-7(1)$ & $-4(1)$ \\
$\mathrm{C}(6)$ & $18(1)$ & $21(1)$ & $19(1)$ & $4(1)$ & $-3(1)$ & $-2(1)$ \\
$\mathrm{C}(7)$ & $16(1)$ & $16(1)$ & $15(1)$ & $2(1)$ & $-2(1)$ & $3(1)$ \\
$\mathrm{C}(8)$ & $15(1)$ & $17(1)$ & $14(1)$ & $3(1)$ & $-1(1)$ & $0(1)$ \\
$\mathrm{C}(9)$ & $17(1)$ & $19(1)$ & $17(1)$ & $3(1)$ & $3(1)$ & $2(1)$ \\
$\mathrm{C}(10)$ & $23(1)$ & $17(1)$ & $17(1)$ & $-1(1)$ & $1(1)$ & $-1(1)$ \\
$\mathrm{C}(11)$ & $16(1)$ & $17(1)$ & $14(1)$ & $-2(1)$ & $3(1)$ & $-1(1)$ \\
$\mathrm{C}(12)$ & $17(1)$ & $18(1)$ & $16(1)$ & $-2(1)$ & $1(1)$ & $-1(1)$ \\
$\mathrm{C}(13)$ & $24(1)$ & $19(1)$ & $22(1)$ & $0(1)$ & $0(1)$ & $-3(1)$ \\
$\mathrm{C}(14)$ & $28(1)$ & $23(1)$ & $18(1)$ & $0(1)$ & $-2(1)$ & $-4(1)$ \\
$\mathrm{C}(15)$ & $19(1)$ & $22(1)$ & $17(1)$ & $-1(1)$ & $-1(1)$ & $-4(1)$ \\
$\mathrm{N}(1)$ & $24(1)$ & $17(1)$ & $16(1)$ & $0(1)$ & $3(1)$ & $3(1)$ \\
$\mathrm{N}(2)$ & $17(1)$ & $16(1)$ & $14(1)$ & $-1(1)$ & $2(1)$ & $-1(1)$ \\
$\mathrm{O}(1)$ & $29(1)$ & $19(1)$ & $21(1)$ & $1(1)$ & $-4(1)$ & $0(1)$ \\
$\mathrm{O}(2)$ & $20(1)$ & $22(1)$ & $21(1)$ & $-4(1)$ & $-3(1)$ & $-4(1)$ \\
& & & & & & \\
\hline
\end{tabular}


Table 5. Hydrogen coordinates ( x 104) and isotropic displacement parameters ( $\AA 2$ x 103) for Compound ent-13.

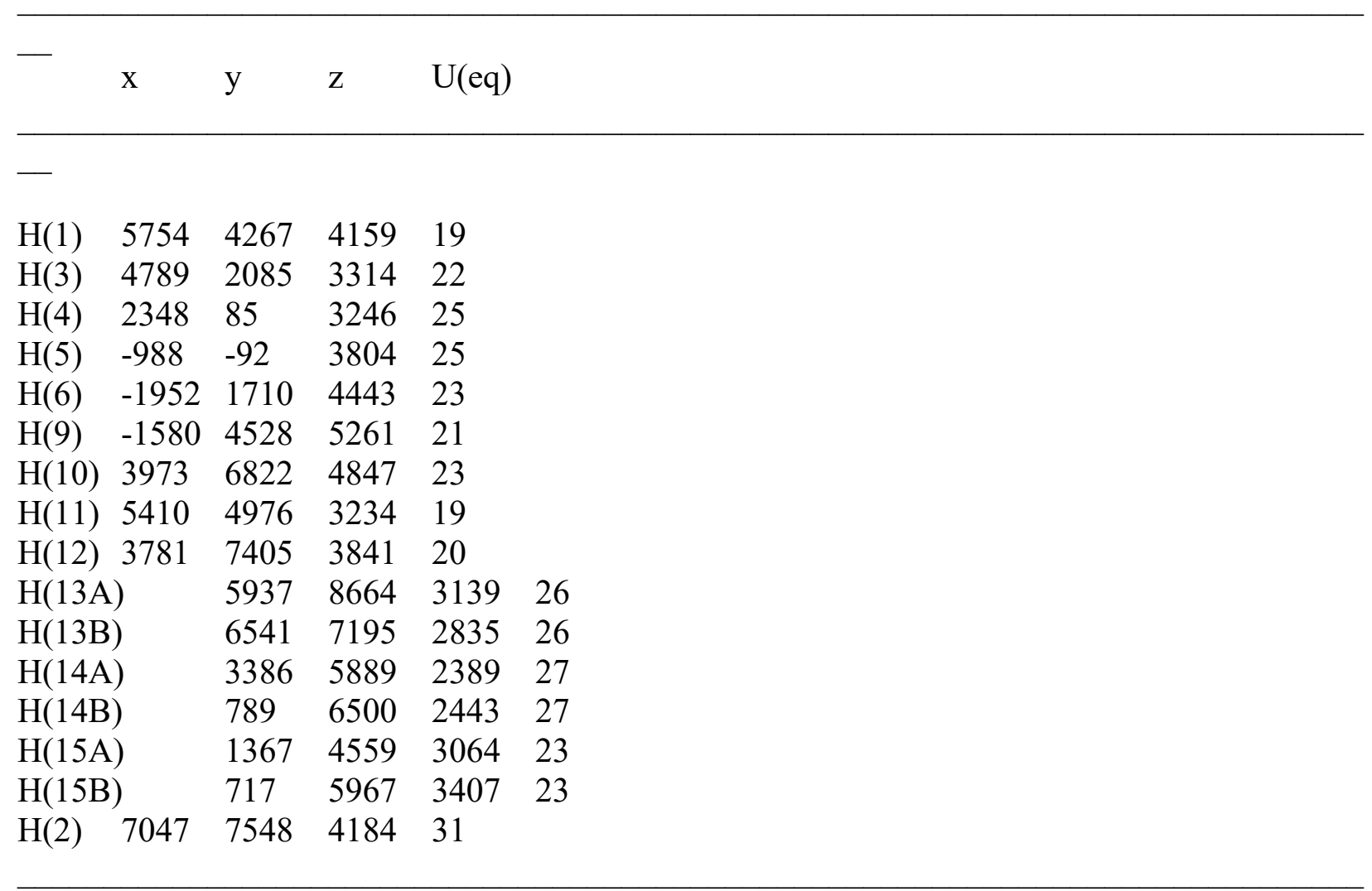




\section{Experimental data for SC-XRD on Compound ent-14}

X-ray quality crystals were grown from a saturated 1,2-dichloroethane/ethanol/methanol solution followed by the slow vapor diffusion of heptane to deposit the crystal diffracted. A colorless plate $0.080 \times 0.050 \times 0.020 \mathrm{~mm}$ in size was mounted on a Cryoloop with Paratone oil. Data were collected in a nitrogen gas stream at 100(2) K using and scans. Crystal-to-detector distance was $60 \mathrm{~mm}$ and exposure time was 4 seconds per frame using a scan width of $2.0^{\circ}$. Data collection was $98.3 \%$ complete to $67.000^{\circ}$ in theta. A total of 7624 reflections were collected covering the indices, $-12<=h<=11,-5<=k<=6,-15<=l<=15.2136$ reflections were found to be symmetry independent, with an $\mathrm{R}_{\text {int }}$ of 0.0768 . Indexing and unit cell refinement indicated a primitive, monoclinic lattice. The space group was found to be P 21 (No. 4). The data were integrated using the Bruker SAINT software program and scaled using the SADABS software program. Solution by iterative methods (SHELXT-2014) produced a complete heavy-atom phasing model consistent with the proposed structure. All non-hydrogen atoms were refined anisotropically by full-matrix least-squares (SHELXL-2014). All hydrogen atoms were placed using a riding model. Their positions were constrained relative to their parent atom using the appropriate HFIX command in SHELXL-2014. Absolute stereochemistry was unambiguously determined to be $R$ at $\mathrm{C} 1$ and $S$ at $\mathrm{C} 11$, and $\mathrm{C} 12$, respectively. 
Table 1. Crystal data and structure refinement for Compound ent-14.

X-ray ID Compound ent-14

Sample/notebook ID Compound ent-14

Empirical formula $\mathrm{C} 15 \mathrm{H} 16 \mathrm{~N} 2 \mathrm{O} 2$

Formula weight $\quad 256.30$

Temperature $100(2) \mathrm{K}$

Wavelength $1.54178 \AA$

Crystal system Monoclinic

Space group P 21

Unit cell dimensions $\mathrm{a}=9.9840(9) \AA \quad$ alpha $=90^{\circ}$.

$$
\begin{array}{ll}
\mathrm{b}=5.4028(3) \AA & \text { beta }=111.475(6)^{\circ} . \\
\mathrm{c}=12.6101(10) \AA & \text { gamma }=90^{\circ} .
\end{array}
$$

Volume $\quad 632.99(9) \AA 3$

Z 2

Density (calculated) $1.345 \mathrm{Mg} / \mathrm{m} 3$

Absorption coefficient $\quad 0.731 \mathrm{~mm}-1$

$\mathrm{F}(000) 272$

Crystal size $\quad 0.080 \times 0.050 \times 0.020 \mathrm{~mm} 3$

Theta range for data collection $\quad 3.767$ to $68.373^{\circ}$.

Index ranges $-12<=\mathrm{h}<=11,-5<=\mathrm{k}<=6,-15<=1<=15$

Reflections collected 7624

Independent reflections $\quad 2136[\mathrm{R}(\mathrm{int})=0.0768]$

Completeness to theta $=67.000^{\circ} \quad 98.3 \%$

Absorption correction Semi-empirical from equivalents

Max. and min. transmission 0.929 and 0.753

Refinement method Full-matrix least-squares on F2

Data / restraints / parameters 2136/1/173

Goodness-of-fit on F2 1.036

Final R indices [ $\mathrm{I}>2 \operatorname{sigma}(\mathrm{I})] \mathrm{R} 1=0.0417, \mathrm{wR} 2=0.0984$

$\mathrm{R}$ indices (all data) $\mathrm{R} 1=0.0490, \mathrm{wR} 2=0.1019$

Absolute structure parameter 0.1(3)

Extinction coefficient $\mathrm{n} / \mathrm{a}$

Largest diff. peak and hole $\quad 0.245$ and -0.208 e. $\AA-3$ 
Table 2. Atomic coordinates ( $\mathrm{x} 104)$ and equivalent isotropic displacement parameters ( $\AA 2 \mathrm{x}$ 103)

for Compound ent-14. U(eq) is defined as one third of the trace of the orthogonalized Uij tensor.

\begin{tabular}{lllll}
\hline & \multicolumn{3}{c}{$\mathrm{U}(\mathrm{eq})$} \\
& $\mathrm{x}$ & $\mathrm{z}$ & \\
$\mathrm{C}$ & & \\
$\mathrm{C}(1)$ & $6156(3)$ & $4049(5)$ & $2954(2)$ & $15(1)$ \\
$\mathrm{C}(2)$ & $4750(3)$ & $5393(5)$ & $2755(2)$ & $16(1)$ \\
$\mathrm{C}(3)$ & $3405(3)$ & $4891(5)$ & $1948(2)$ & $19(1)$ \\
$\mathrm{C}(4)$ & $2255(3)$ & $6421(6)$ & $1897(2)$ & $22(1)$ \\
$\mathrm{C}(5)$ & $2456(3)$ & $8427(6)$ & $2634(3)$ & $24(1)$ \\
$\mathrm{C}(6)$ & $3808(3)$ & $8942(5)$ & $3437(3)$ & $21(1)$ \\
$\mathrm{C}(7)$ & $4955(3)$ & $7421(5)$ & $3497(2)$ & $16(1)$ \\
$\mathrm{C}(8)$ & $6466(3)$ & $7433(5)$ & $4243(2)$ & $17(1)$ \\
$\mathrm{C}(9)$ & $7480(3)$ & $8427(5)$ & $5207(2)$ & $19(1)$ \\
$\mathrm{C}(10)$ & $8470(3)$ & $5302(5)$ & $4696(2)$ & $19(1)$ \\
$\mathrm{C}(11)$ & $6606(3)$ & $3997(5)$ & $1905(2)$ & $15(1)$ \\
$\mathrm{C}(12)$ & $8191(3)$ & $3341(5)$ & $2216(2)$ & $16(1)$ \\
$\mathrm{C}(13)$ & $8525(3)$ & $3201(5)$ & $1131(2)$ & $20(1)$ \\
$\mathrm{C}(14)$ & $8135(3)$ & $5664(6)$ & $498(3) 23(1)$ \\
$\mathrm{C}(15)$ & $6306(3)$ & $6429(5)$ & $1232(2)$ & $20(1)$ \\
$\mathrm{N}(1)$ & $8737(3)$ & $7062(5)$ & $5484(2)$ & $20(1)$ \\
$\mathrm{N}(2)$ & $7128(3)$ & $5478(4)$ & $3931(2)$ & $16(1)$ \\
$\mathrm{O}(1)$ & $6651(2)$ & $6211(4)$ & $227(2) 23(1)$ \\
$\mathrm{O}(2)$ & $8513(2)$ & $1082(4)$ & $2836(2)$ & $20(1)$ \\
& & &
\end{tabular}


Table 3. Bond lengths $[\AA]$ and angles $\left[^{\circ}\right]$ for Compound ent- 14 .

\begin{tabular}{|c|c|c|c|c|}
\hline $\mathrm{C}(1)-\mathrm{N}(2)$ & $1.477(3)$ & $\mathrm{C}(10)-\mathrm{N}(1)$ & \multicolumn{2}{|c|}{$1.330(4)$} \\
\hline $\mathrm{C}(1)-\mathrm{C}(2)$ & $1.517(4)$ & $\mathrm{C}(10)-\mathrm{N}(2)$ & \multicolumn{2}{|c|}{$1.337(4)$} \\
\hline$C(1)-C(11)$ & $1.546(4)$ & $\mathrm{C}(10)-\mathrm{H}(10)$ & \multicolumn{2}{|c|}{0.9500} \\
\hline $\mathrm{C}(1)-\mathrm{H}(1)$ & 1.0000 & $\mathrm{C}(11)-\mathrm{C}(12)$ & \multicolumn{2}{|c|}{$1.526(3)$} \\
\hline$C(2)-C(3)$ & $1.383(4)$ & $C(11)-C(15)$ & \multicolumn{2}{|c|}{$1.533(4)$} \\
\hline $\mathrm{C}(2)-\mathrm{C}(7)$ & $1.406(4)$ & $\mathrm{C}(11)-\mathrm{H}(11)$ & \multicolumn{2}{|c|}{1.0000} \\
\hline$C(3)-C(4)$ & $1.397(4)$ & $\mathrm{C}(12)-\mathrm{O}(2)$ & \multicolumn{2}{|c|}{$1.421(3)$} \\
\hline $\mathrm{C}(3)-\mathrm{H}(3)$ & 0.9500 & $\mathrm{C}(12)-\mathrm{C}(13)$ & \multicolumn{2}{|c|}{$1.525(4)$} \\
\hline$C(4)-C(5)$ & $1.394(4)$ & $\mathrm{C}(12)-\mathrm{H}(12)$ & \multicolumn{2}{|c|}{1.0000} \\
\hline $\mathrm{C}(4)-\mathrm{H}(4)$ & 0.9500 & $C(13)-C(14)$ & \multicolumn{2}{|c|}{$1.527(4)$} \\
\hline$C(5)-C(6)$ & $1.387(4)$ & $\mathrm{C}(13)-\mathrm{H}(13 \mathrm{~A})$ & & 0.9900 \\
\hline $\mathrm{C}(5)-\mathrm{H}(5)$ & 0.9500 & $\mathrm{C}(13)-\mathrm{H}(13 \mathrm{~B})$ & \multirow{2}{*}{\multicolumn{2}{|c|}{0.9900}} \\
\hline$C(6)-C(7)$ & \multirow{2}{*}{$1.388(4)$} & $\mathrm{C}(14)-\mathrm{O}(1)$ & & \\
\hline $\mathrm{C}(6)-\mathrm{H}(6)$ & & $\mathrm{C}(14)-\mathrm{H}(14 \mathrm{~A})$ & & 0.9900 \\
\hline $\mathrm{C}(7)-\mathrm{C}(8)$ & & $\mathrm{C}(14)-\mathrm{H}(14 \mathrm{~B})$ & 0.9900 & \\
\hline $\mathrm{C}(8)-\mathrm{C}(9)$ & & $\mathrm{C}(15)-\mathrm{O}(1)$ & $1.435(3$ & \\
\hline $\mathrm{C}(8)-\mathrm{N}(2)$ & & $\mathrm{C}(15)-\mathrm{H}(15 \mathrm{~A})$ & & 0.9900 \\
\hline $\mathrm{C}(9)-\mathrm{N}(1)$ & & $\mathrm{C}(15)-\mathrm{H}(15 \mathrm{~B})$ & 0.9900 & \\
\hline $\mathrm{C}(9)-\mathrm{H}(9)$ & & $\mathrm{O}(2)-\mathrm{H}(2)$ & 0.8400 & \\
\hline $\mathrm{N}(2)-\mathrm{C}(1)-\mathrm{C}(2)$ & $100.0(2)$ & $\mathrm{C}(9)-\mathrm{C}(8)-\mathrm{N}(2$ & & $106.1(3)$ \\
\hline $\mathrm{N}(2)-\mathrm{C}(1)-\mathrm{C}(11)$ & $114.5(2)$ & $\mathrm{C}(9)-\mathrm{C}(8)-\mathrm{C}(7$ & & $145.7(3)$ \\
\hline $\mathrm{C}(2)-\mathrm{C}(1)-\mathrm{C}(11)$ & $114.1(2)$ & $\mathrm{N}(2)-\mathrm{C}(8)-\mathrm{C}(7$ & & $107.7(2)$ \\
\hline $\mathrm{N}(2)-\mathrm{C}(1)-\mathrm{H}(1)$ & 109.3 & $\mathrm{C}(8)-\mathrm{C}(9)-\mathrm{N}(1$ & & $108.7(3)$ \\
\hline $\mathrm{C}(2)-\mathrm{C}(1)-\mathrm{H}(1)$ & 109.3 & $\mathrm{C}(8)-\mathrm{C}(9)-\mathrm{H}(9$ & & 125.6 \\
\hline $\mathrm{C}(11)-\mathrm{C}(1)-\mathrm{H}(1)$ & 109.3 & $\mathrm{~N}(1)-\mathrm{C}(9)-\mathrm{H}(9$ & & 125.6 \\
\hline$C(3)-C(2)-C(7)$ & $120.5(3)$ & $\mathrm{N}(1)-\mathrm{C}(10)-\mathrm{N}($ & & $111.2(3)$ \\
\hline $\mathrm{C}(3)-\mathrm{C}(2)-\mathrm{C}(1)$ & $128.2(3)$ & $\mathrm{N}(1)-\mathrm{C}(10)-\mathrm{H}($ & (10) & 124.4 \\
\hline $\mathrm{C}(7)-\mathrm{C}(2)-\mathrm{C}(1)$ & $111.3(2)$ & $\mathrm{N}(2)-\mathrm{C}(10)-\mathrm{H}($ & (10) & 124.4 \\
\hline$C(2)-C(3)-C(4)$ & $118.5(3)$ & $C(12)-C(11)-C$ & $C(15)$ & $108.4(2)$ \\
\hline $\mathrm{C}(2)-\mathrm{C}(3)-\mathrm{H}(3)$ & 120.7 & $C(12)-C(11)-C$ & $C(1)$ & $112.5(2)$ \\
\hline $\mathrm{C}(4)-\mathrm{C}(3)-\mathrm{H}(3)$ & 120.7 & $C(15)-C(11)-C$ & C(1) & $113.5(2)$ \\
\hline $\mathrm{C}(5)-\mathrm{C}(4)-\mathrm{C}(3)$ & $121.0(3)$ & $\mathrm{C}(12)-\mathrm{C}(11)-\mathrm{H}$ & $\mathrm{H}(11)$ & 107.4 \\
\hline $\mathrm{C}(5)-\mathrm{C}(4)-\mathrm{H}(4)$ & 119.5 & $\mathrm{C}(15)-\mathrm{C}(11)-\mathrm{H}$ & H(11) & 107.4 \\
\hline $\mathrm{C}(3)-\mathrm{C}(4)-\mathrm{H}(4)$ & 119.5 & $\mathrm{C}(1)-\mathrm{C}(11)-\mathrm{H}($ & (11) & 107.4 \\
\hline$C(6)-C(5)-C(4)$ & $120.4(3)$ & $\mathrm{O}(2)-\mathrm{C}(12)-\mathrm{C}($ & (13) & $111.8(2)$ \\
\hline $\mathrm{C}(6)-\mathrm{C}(5)-\mathrm{H}(5)$ & 119.8 & $\mathrm{O}(2)-\mathrm{C}(12)-\mathrm{C}($ & (11) & $110.2(2)$ \\
\hline $\mathrm{C}(4)-\mathrm{C}(5)-\mathrm{H}(5)$ & 119.8 & $C(13)-C(12)-C$ & $C(11)$ & $109.1(2)$ \\
\hline$C(5)-C(6)-C(7)$ & $118.9(3)$ & $\mathrm{O}(2)-\mathrm{C}(12)-\mathrm{H}($ & (12) & 108.6 \\
\hline $\mathrm{C}(5)-\mathrm{C}(6)-\mathrm{H}(6)$ & 120.5 & $\mathrm{C}(13)-\mathrm{C}(12)-\mathrm{H}$ & $\mathrm{H}(12)$ & 108.6 \\
\hline $\mathrm{C}(7)-\mathrm{C}(6)-\mathrm{H}(6)$ & 120.5 & $\mathrm{C}(11)-\mathrm{C}(12)-\mathrm{H}$ & $\mathrm{H}(12)$ & 108.6 \\
\hline$C(6)-C(7)-C(2)$ & $120.6(3)$ & $C(12)-C(13)-C$ & $C(14)$ & $109.1(2)$ \\
\hline$C(6)-C(7)-C(8)$ & $132.1(3)$ & $\mathrm{C}(12)-\mathrm{C}(13)-\mathrm{H}$ & $\mathrm{H}(13 \mathrm{~A})$ & 109.9 \\
\hline $\mathrm{C}(2)-\mathrm{C}(7)-\mathrm{C}(8)$ & $107.3(2)$ & $\mathrm{C}(14)-\mathrm{C}(13)-\mathrm{H}$ & $\mathrm{H}(13 \mathrm{~A})$ & 109.9 \\
\hline
\end{tabular}


$\mathrm{C}(12)-\mathrm{C}(13)-\mathrm{H}(13 \mathrm{~B}) \quad 109.9$

$\mathrm{C}(14)-\mathrm{C}(13)-\mathrm{H}(13 \mathrm{~B}) \quad 109.9$

$\mathrm{H}(13 \mathrm{~A})-\mathrm{C}(13)-\mathrm{H}(13 \mathrm{~B}) \quad 108.3$

$\mathrm{O}(1)-\mathrm{C}(14)-\mathrm{C}(13) \quad 110.5(2)$

$\mathrm{O}(1)-\mathrm{C}(14)-\mathrm{H}(14 \mathrm{~A}) \quad 109.5$

$\mathrm{C}(13)-\mathrm{C}(14)-\mathrm{H}(14 \mathrm{~A}) \quad 109.5$

$\mathrm{O}(1)-\mathrm{C}(14)-\mathrm{H}(14 \mathrm{~B}) \quad 109.5$

$\mathrm{C}(13)-\mathrm{C}(14)-\mathrm{H}(14 \mathrm{~B}) \quad 109.5$

$\mathrm{H}(14 \mathrm{~A})-\mathrm{C}(14)-\mathrm{H}(14 \mathrm{~B})$

$\mathrm{O}(1)-\mathrm{C}(15)-\mathrm{C}(11) \quad 110.9(2)$

$\mathrm{O}(1)-\mathrm{C}(15)-\mathrm{H}(15 \mathrm{~A}) \quad 109.5$
$\mathrm{C}(11)-\mathrm{C}(15)-\mathrm{H}(15 \mathrm{~A}) \quad 109.5$

$\mathrm{O}(1)-\mathrm{C}(15)-\mathrm{H}(15 \mathrm{~B}) \quad 109.5$

$\mathrm{C}(11)-\mathrm{C}(15)-\mathrm{H}(15 \mathrm{~B}) \quad 109.5$

$\mathrm{H}(15 \mathrm{~A})-\mathrm{C}(15)-\mathrm{H}(15 \mathrm{~B})$

$\mathrm{C}(10)-\mathrm{N}(1)-\mathrm{C}(9) \quad 106.1(2)$

$\mathrm{C}(10)-\mathrm{N}(2)-\mathrm{C}(8) \quad 107.9(2)$

$\mathrm{C}(10)-\mathrm{N}(2)-\mathrm{C}(1) \quad 138.0(2)$

$\mathrm{C}(8)-\mathrm{N}(2)-\mathrm{C}(1) \quad 113.7(2)$

C(14)-O(1)-C(15) 111.7(2)

$\mathrm{C}(12)-\mathrm{O}(2)-\mathrm{H}(2) \quad 109.5$

108.1

Symmetry transformations used to generate equivalent atoms: 
Table 4. Anisotropic displacement parameters ( $\AA 2 \mathrm{x} 103)$ for Compound ent-14. The anisotropic displacement factor exponent takes the form: $-2 \square 2\left[\mathrm{~h} 2 \mathrm{a}^{*} 2 \mathrm{U} 11+\ldots+2 \mathrm{~h} \mathrm{k} \mathrm{a} * \mathrm{~b} * \mathrm{U} 12\right.$ ]

\begin{tabular}{lllllll}
\hline & $\mathrm{U} 11$ & $\mathrm{U} 22$ & $\mathrm{U} 33$ & $\mathrm{U} 23$ & $\mathrm{U} 13$ & $\mathrm{U} 12$ \\
\hline $\mathrm{C}(1)$ & $13(1)$ & $17(1)$ & $15(1)$ & $-1(1)$ & $3(1)$ & $-1(1)$ \\
$\mathrm{C}(2)$ & $17(1)$ & $15(1)$ & $18(1)$ & $2(1)$ & $9(1)$ & $0(1)$ \\
$\mathrm{C}(3)$ & $15(1)$ & $22(2)$ & $18(1)$ & $1(1)$ & $3(1)$ & $-2(1)$ \\
$\mathrm{C}(4)$ & $15(1)$ & $29(2)$ & $22(1)$ & $5(1)$ & $6(1)$ & $-2(1)$ \\
$\mathrm{C}(5)$ & $22(2)$ & $29(2)$ & $24(1)$ & $9(1)$ & $13(1)$ & $8(1)$ \\
$\mathrm{C}(6)$ & $26(2)$ & $20(2)$ & $22(1)$ & $1(1)$ & $14(1)$ & $3(1)$ \\
$\mathrm{C}(7)$ & $18(1)$ & $16(1)$ & $16(1)$ & $3(1)$ & $9(1)$ & $-2(1)$ \\
$\mathrm{C}(8)$ & $22(2)$ & $14(1)$ & $18(1)$ & $3(1)$ & $11(1)$ & $2(1)$ \\
$\mathrm{C}(9)$ & $22(1)$ & $18(1)$ & $18(1)$ & $-4(1)$ & $10(1)$ & $-4(1)$ \\
$\mathrm{C}(10)$ & $18(1)$ & $23(2)$ & $18(1)$ & $0(1)$ & $7(1)$ & $0(1)$ \\
$\mathrm{C}(11)$ & $17(1)$ & $14(1)$ & $15(1)$ & $-3(1)$ & $6(1)$ & $0(1)$ \\
$\mathrm{C}(12)$ & $16(1)$ & $14(1)$ & $16(1)$ & $0(1)$ & $4(1)$ & $0(1)$ \\
$\mathrm{C}(13)$ & $19(1)$ & $19(1)$ & $20(1)$ & $2(1)$ & $7(1)$ & $4(1)$ \\
$\mathrm{C}(14)$ & $22(1)$ & $26(2)$ & $24(1)$ & $7(1)$ & $11(1)$ & $6(1)$ \\
$\mathrm{C}(15)$ & $19(1)$ & $20(2)$ & $20(1)$ & $2(1)$ & $8(1)$ & $4(1)$ \\
$\mathrm{N}(1)$ & $15(1)$ & $27(1)$ & $17(1)$ & $-2(1)$ & $4(1)$ & $-3(1)$ \\
$\mathrm{N}(2)$ & $17(1)$ & $16(1)$ & $15(1)$ & $-2(1)$ & $6(1)$ & $0(1)$ \\
$\mathrm{O}(1)$ & $21(1)$ & $31(1)$ & $19(1)$ & $6(1)$ & $9(1)$ & $7(1)$ \\
$\mathrm{O}(2)$ & $20(1)$ & $18(1)$ & $20(1)$ & $3(1)$ & $4(1)$ & $2(1)$ \\
& & & & & & \\
\hline
\end{tabular}


Table 5. Hydrogen coordinates ( x 104) and isotropic displacement parameters ( $\AA 2$ x 103) for Compound ent-14.

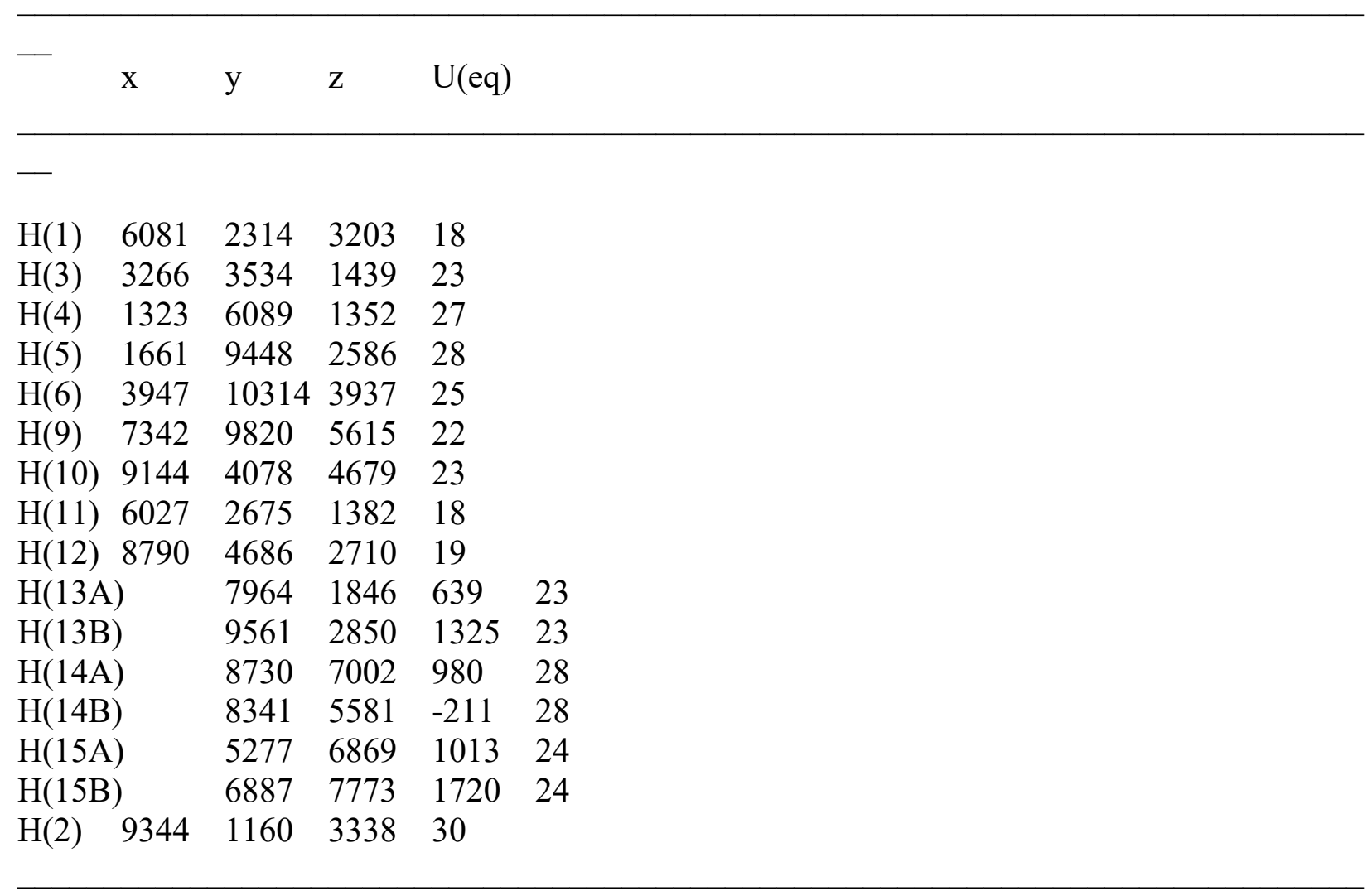




\section{Experimental data for SC-XRD on Compound 20}

X-ray quality crystals were grown from a saturated 1,2-dichloroethane/ethanol/methanol solution followed by the slow vapor diffusion of diisopropyl ether to deposit the crystal diffracted. A colorless needle $0.040 \times 0.010 \times 0.010 \mathrm{~mm}$ in size was mounted on a Cryoloop with Paratone oil. Data were collected in a nitrogen gas stream at 100(2) K using and scans. Crystal-to-detector distance was $60 \mathrm{~mm}$ and exposure time was 30 seconds per frame using a scan width of $2.0^{\circ}$. Data collection was $98.1 \%$ complete to $50.000^{\circ}$ in theta. A total of 9062 reflections were collected covering the indices, $-13<=h<=13,-4<=k<=4,-15<=l<=15.2151$ reflections were found to be symmetry independent, with an $\mathrm{R}_{\text {int }}$ of 0.0871 . Indexing and unit cell refinement indicated a primitive, monoclinic lattice. The space group was found to be P 21 (No. 4). The data were integrated using the Bruker SAINT software program and scaled using the SADABS software program. Solution by iterative methods (SHELXT-2014) produced a complete heavyatom phasing model consistent with the proposed structure. All non-hydrogen atoms were refined anisotropically by full-matrix least-squares (SHELXL-2014). All hydrogen atoms were placed using a riding model. Their positions were constrained relative to their parent atom using the appropriate HFIX command in SHELXL-2014. 
Table 1. Crystal data and structure refinement for Compound 20.

X-ray ID Compound 20

Sample/notebook ID Compound 20

Empirical formula $\quad \mathrm{C} 27 \mathrm{H} 25 \mathrm{~N} 3 \mathrm{O} 4$

Formula weight $\quad 455.50$

Temperature $100(2) \mathrm{K}$

Wavelength $1.54178 \AA$

Crystal system Monoclinic

Space group $\mathrm{P} 21$

Unit cell dimensions $\mathrm{a}=13.777(6) \AA \quad$ alpha $=90^{\circ}$. $\mathrm{b}=5.073(2) \AA$ \&eta $=103.272(7)^{\circ}$.

$\mathrm{c}=15.860(6) \AA \quad$ gamma $=90^{\circ}$.

Volume $\quad 1078.9(8) \AA 3$

Z 2

Density (calculated) $\quad 1.402 \mathrm{Mg} / \mathrm{m} 3$

Absorption coefficient $\quad 0.775 \mathrm{~mm}-1$

$\mathrm{F}(000) 480$

Crystal size $\quad 0.040 \times 0.010 \times 0.010 \mathrm{~mm} 3$

Theta range for data collection $\quad 2.862$ to $50.420^{\circ}$.

Index ranges $-13<=\mathrm{h}<=13,-4<=\mathrm{k}<=4,-15<=1<=15$

Reflections collected 9062

Independent reflections $\quad 2151[\mathrm{R}(\mathrm{int})=0.0871]$

Completeness to theta $=50.000^{\circ} \quad 98.1 \%$

Absorption correction Semi-empirical from equivalents

Max. and min. transmission 0.929 and 0.784

Refinement method Full-matrix least-squares on F2

Data / restraints / parameters 2151/1/309

Goodness-of-fit on F2 1.024

Final $\mathrm{R}$ indices $[\mathrm{I}>2 \operatorname{sigma}(\mathrm{I})] \mathrm{R} 1=0.0394, \mathrm{wR} 2=0.0774$

$\mathrm{R}$ indices (all data) $\mathrm{R} 1=0.0650, \mathrm{wR} 2=0.0875$

Absolute structure parameter 0.3(4)

Extinction coefficient $\mathrm{n} / \mathrm{a}$

Largest diff. peak and hole $\quad 0.190$ and -0.194 e. $\AA$-3 
Table 2. Atomic coordinates ( $\mathrm{x} 104)$ and equivalent isotropic displacement parameters ( $\AA 2 \mathrm{x}$ 103)

for Compound 20. $\mathrm{U}(\mathrm{eq})$ is defined as one third of the trace of the orthogonalized Uij tensor.

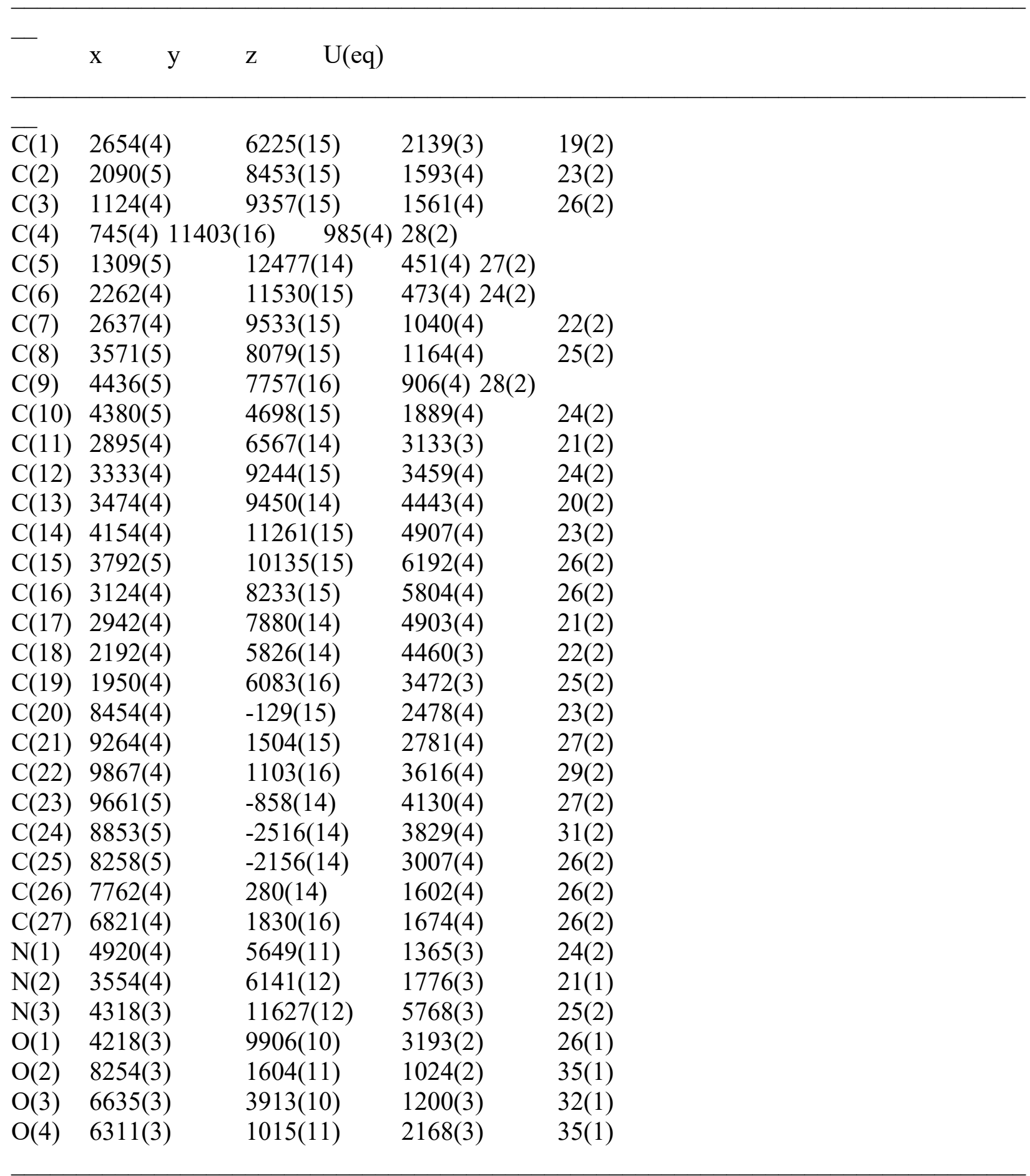


Table 3. Bond lengths $[\AA]$ and angles $\left[{ }^{\circ}\right]$ for Compound 20.

\begin{tabular}{|c|c|c|c|}
\hline $\mathrm{C}(1)-\mathrm{N}(2)$ & $1.483(7)$ & $\mathrm{C}(15)-\mathrm{N}(3)$ & $1.333(8)$ \\
\hline $\mathrm{C}(1)-\mathrm{C}(2)$ & $1.524(9)$ & $C(15)-C(16)$ & $1.378(9)$ \\
\hline $\mathrm{C}(1)-\mathrm{C}(11)$ & $1.545(8)$ & $\mathrm{C}(15)-\mathrm{H}(15)$ & 0.9500 \\
\hline $\mathrm{C}(1)-\mathrm{H}(1)$ & 1.0000 & $C(16)-C(17)$ & $1.404(8)$ \\
\hline$C(2)-C(7)$ & $1.393(9)$ & $\mathrm{C}(16)-\mathrm{H}(16)$ & 0.9500 \\
\hline $\mathrm{C}(2)-\mathrm{C}(3)$ & $1.397(8)$ & $\mathrm{C}(17)-\mathrm{C}(18)$ & $1.521(9)$ \\
\hline$C(3)-C(4)$ & $1.401(9)$ & $\mathrm{C}(18)-\mathrm{C}(19)$ & \\
\hline $\mathrm{C}(3)-\mathrm{H}(3)$ & 0.9500 & $\mathrm{C}(18)-\mathrm{H}(18 \mathrm{~A})$ & $\begin{array}{r}1.532(8) \\
0.9900\end{array}$ \\
\hline$C(4)-C(5)$ & $1.386(9)$ & $\mathrm{C}(18)-\mathrm{H}(18 \mathrm{~B})$ & \\
\hline $\mathrm{C}(4)-\mathrm{H}(4)$ & 0.9500 & $\mathrm{C}(19)-\mathrm{H}(19 \mathrm{~A})$ & $\begin{array}{l}0.9900 \quad \\
\quad 0.9900\end{array}$ \\
\hline$C(5)-C(6)$ & $1.391(8)$ & $\mathrm{C}(19)-\mathrm{H}(19 \mathrm{~B})$ & \multirow{2}{*}{0.9900} \\
\hline $\mathrm{C}(5)-\mathrm{H}(5)$ & 0.9500 & $C(20)-C(21)$ & \\
\hline$C(6)-C(7)$ & $1.374(9)$ & $C(20)-C(25)$ & $\begin{array}{l}1.385(8) \\
1.393(9)\end{array}$ \\
\hline $\mathrm{C}(6)-\mathrm{H}(6)$ & 0.9500 & $C(20)-C(26)$ & $\begin{array}{l}1.393(9) \\
1.508(8)\end{array}$ \\
\hline $\mathrm{C}(7)-\mathrm{C}(8)$ & $1.457(9)$ & $C(21)-C(22)$ & $1.408(8)$ \\
\hline $\mathrm{C}(8)-\mathrm{C}(9)$ & $1.356(8)$ & $\mathrm{C}(21)-\mathrm{H}(21)$ & 0.9500 \\
\hline $\mathrm{C}(8)-\mathrm{N}(2)$ & $1.386(8)$ & $\mathrm{C}(22)-\mathrm{C}(23)$ & $1.357(9)$ \\
\hline $\mathrm{C}(9)-\mathrm{N}(1)$ & $1.376(8)$ & $\mathrm{C}(22)-\mathrm{H}(22)$ & 0.9500 \\
\hline $\mathrm{C}(9)-\mathrm{H}(9)$ & 0.9500 & $\mathrm{C}(23)-\mathrm{C}(24)$ & $1.389(9)$ \\
\hline $\mathrm{C}(10)-\mathrm{N}(1)$ & $1.328(7)$ & $\mathrm{C}(23)-\mathrm{H}(23)$ & 0.9500 \\
\hline $\mathrm{C}(10)-\mathrm{N}(2)$ & $1.330(8)$ & $\mathrm{C}(24)-\mathrm{C}(25)$ & $1.384(8)$ \\
\hline $\mathrm{C}(10)-\mathrm{H}(10)$ & 0.9500 & $\mathrm{C}(24)-\mathrm{H}(24)$ & 0.9500 \\
\hline$C(11)-C(12)$ & $1.527(9)$ & $\mathrm{C}(25)-\mathrm{H}(25)$ & 0.9500 \\
\hline$C(11)-C(19)$ & $1.537(8)$ & $\mathrm{C}(26)-\mathrm{O}(2)$ & $1.428(7)$ \\
\hline $\mathrm{C}(11)-\mathrm{H}(11)$ & 1.0000 & $C(26)-C(27)$ & $1.542(9)$ \\
\hline $\mathrm{C}(12)-\mathrm{O}(1)$ & $1.420(7)$ & $\mathrm{C}(26)-\mathrm{H}(26)$ & 1.0000 \\
\hline$C(12)-C(13)$ & $1.531(8)$ & $\mathrm{C}(27)-\mathrm{O}(4)$ & $1.237(8)$ \\
\hline $\mathrm{C}(12)-\mathrm{H}(12)$ & 1.0000 & $\mathrm{C}(27)-\mathrm{O}(3)$ & $1.288(8)$ \\
\hline$C(13)-C(14)$ & $1.396(8)$ & $\mathrm{N}(1)-\mathrm{H}(1 \mathrm{~A})$ & 0.8800 \\
\hline $\mathrm{C}(13)-\mathrm{C}(17)$ & $1.396(9)$ & $\mathrm{O}(1)-\mathrm{H}(1 \mathrm{~A})$ & 0.8400 \\
\hline $\mathrm{C}(14)-\mathrm{N}(3)$ & $1.344(7)$ & $\mathrm{O}(2)-\mathrm{H}(2)$ & 0.8400 \\
\hline C(14)-H(14) & 0.9500 & & \\
\hline $\mathrm{N}(2)-\mathrm{C}(1)-\mathrm{C}(2)$ & $99.4(5)$ & $\mathrm{C}(4)-\mathrm{C}(3)-\mathrm{H}(3)$ & 120.8 \\
\hline $\mathrm{N}(2)-\mathrm{C}(1)-\mathrm{C}(11$ & $113.4(4)$ & $\mathrm{C}(5)-\mathrm{C}(4)-\mathrm{C}(3)$ & $120.8(6)$ \\
\hline$C(2)-C(1)-C(11$ & $117.3(6)$ & $\mathrm{C}(5)-\mathrm{C}(4)-\mathrm{H}(4)$ & 119.6 \\
\hline $\mathrm{N}(2)-\mathrm{C}(1)-\mathrm{H}(1)$ & 108.7 & $\mathrm{C}(3)-\mathrm{C}(4)-\mathrm{H}(4)$ & 119.6 \\
\hline $\mathrm{C}(2)-\mathrm{C}(1)-\mathrm{H}(1)$ & 108.7 & $C(4)-C(5)-C(6)$ & $120.4(7)$ \\
\hline $\mathrm{C}(11)-\mathrm{C}(1)-\mathrm{H}(1)$ & 108.7 & $\mathrm{C}(4)-\mathrm{C}(5)-\mathrm{H}(5)$ & 119.8 \\
\hline$C(7)-C(2)-C(3)$ & $119.7(6)$ & $\mathrm{C}(6)-\mathrm{C}(5)-\mathrm{H}(5)$ & 119.8 \\
\hline $\mathrm{C}(7)-\mathrm{C}(2)-\mathrm{C}(1)$ & $111.7(6)$ & $\mathrm{C}(7)-\mathrm{C}(6)-\mathrm{C}(5)$ & $118.8(6)$ \\
\hline $\mathrm{C}(3)-\mathrm{C}(2)-\mathrm{C}(1)$ & $128.4(6)$ & $\mathrm{C}(7)-\mathrm{C}(6)-\mathrm{H}(6)$ & 120.6 \\
\hline$C(2)-C(3)-C(4)$ & $118.4(6)$ & $\mathrm{C}(5)-\mathrm{C}(6)-\mathrm{H}(6)$ & 120.6 \\
\hline $\mathrm{C}(2)-\mathrm{C}(3)-\mathrm{H}(3)$ & 120.8 & $\mathrm{C}(6)-\mathrm{C}(7)-\mathrm{C}(2)$ & $121.7(6)$ \\
\hline
\end{tabular}




\begin{tabular}{|c|c|c|c|}
\hline$C(6)-C(7)-C(8)$ & $130.5(6)$ & $\mathrm{H}(18 \mathrm{~A})-\mathrm{C}(18)-\mathrm{H}(18 \mathrm{~B}$ & ) $\quad 107.9$ \\
\hline$C(2)-C(7)-C(8)$ & $107.7(6)$ & C(18)-C(19)-C(11) & $111.6(5)$ \\
\hline $\mathrm{C}(9)-\mathrm{C}(8)-\mathrm{N}(2)$ & $106.5(6)$ & C(18)-C(19)-H(19A) & 109.3 \\
\hline $\mathrm{C}(9)-\mathrm{C}(8)-\mathrm{C}(7)$ & $146.2(7)$ & C(11)-C(19)-H(19A) & 109.3 \\
\hline $\mathrm{N}(2)-\mathrm{C}(8)-\mathrm{C}(7)$ & $107.3(6)$ & C(18)-C(19)-H(19B) & 109.3 \\
\hline $\mathrm{C}(8)-\mathrm{C}(9)-\mathrm{N}(1)$ & $106.7(6)$ & C(11)-C(19)-H(19B) & 109.3 \\
\hline $\mathrm{C}(8)-\mathrm{C}(9)-\mathrm{H}(9)$ & 126.7 & $\mathrm{H}(19 \mathrm{~A})-\mathrm{C}(19)-\mathrm{H}(19 \mathrm{~B})$ & ) $\quad 108.0$ \\
\hline $\mathrm{N}(1)-\mathrm{C}(9)-\mathrm{H}(9)$ & 126.7 & $\mathrm{C}(21)-\mathrm{C}(20)-\mathrm{C}(25)$ & $119.0(5)$ \\
\hline $\mathrm{N}(1)-\mathrm{C}(10)-\mathrm{N}(2)$ & $107.5(6)$ & $C(21)-C(20)-C(26)$ & $121.8(6)$ \\
\hline $\mathrm{N}(1)-\mathrm{C}(10)-\mathrm{H}(10)$ & 126.3 & $C(25)-C(20)-C(26)$ & $119.2(6)$ \\
\hline N(2)-C(10)-H(10) & 126.3 & $\mathrm{C}(20)-\mathrm{C}(21)-\mathrm{C}(22)$ & $119.6(6)$ \\
\hline$C(12)-C(11)-C(19)$ & $108.9(5)$ & $\mathrm{C}(20)-\mathrm{C}(21)-\mathrm{H}(21)$ & 120.2 \\
\hline C(12)-C(11)-C(1) & $114.9(5)$ & $\mathrm{C}(22)-\mathrm{C}(21)-\mathrm{H}(21)$ & 120.2 \\
\hline C(19)-C(11)-C(1) & $109.7(4)$ & $C(23)-C(22)-C(21)$ & $120.8(7)$ \\
\hline $\mathrm{C}(12)-\mathrm{C}(11)-\mathrm{H}(11)$ & 107.7 & $\mathrm{C}(23)-\mathrm{C}(22)-\mathrm{H}(22)$ & 119.6 \\
\hline $\mathrm{C}(19)-\mathrm{C}(11)-\mathrm{H}(11)$ & 107.7 & $\mathrm{C}(21)-\mathrm{C}(22)-\mathrm{H}(22)$ & 119.6 \\
\hline $\mathrm{C}(1)-\mathrm{C}(11)-\mathrm{H}(11)$ & 107.7 & $C(22)-C(23)-C(24)$ & $119.9(6)$ \\
\hline $\mathrm{O}(1)-\mathrm{C}(12)-\mathrm{C}(11)$ & $114.2(5)$ & $\mathrm{C}(22)-\mathrm{C}(23)-\mathrm{H}(23)$ & 120.1 \\
\hline $\mathrm{O}(1)-\mathrm{C}(12)-\mathrm{C}(13)$ & $111.8(5)$ & $\mathrm{C}(24)-\mathrm{C}(23)-\mathrm{H}(23)$ & 120.1 \\
\hline$C(11)-C(12)-C(13)$ & $110.7(5)$ & $C(25)-C(24)-C(23)$ & $119.9(6)$ \\
\hline $\mathrm{O}(1)-\mathrm{C}(12)-\mathrm{H}(12)$ & 106.6 & $\mathrm{C}(25)-\mathrm{C}(24)-\mathrm{H}(24)$ & 120.0 \\
\hline $\mathrm{C}(11)-\mathrm{C}(12)-\mathrm{H}(12)$ & 106.6 & $\mathrm{C}(23)-\mathrm{C}(24)-\mathrm{H}(24)$ & 120.0 \\
\hline $\mathrm{C}(13)-\mathrm{C}(12)-\mathrm{H}(12)$ & 106.6 & $C(24)-C(25)-C(20)$ & $120.7(6)$ \\
\hline $\mathrm{C}(14)-\mathrm{C}(13)-\mathrm{C}(17)$ & $118.0(5)$ & $\mathrm{C}(24)-\mathrm{C}(25)-\mathrm{H}(25)$ & 119.7 \\
\hline$C(14)-C(13)-C(12)$ & $119.7(6)$ & $\mathrm{C}(20)-\mathrm{C}(25)-\mathrm{H}(25)$ & 119.7 \\
\hline$C(17)-C(13)-C(12)$ & $122.3(6)$ & $\mathrm{O}(2)-\mathrm{C}(26)-\mathrm{C}(20)$ & $111.3(5)$ \\
\hline $\mathrm{N}(3)-\mathrm{C}(14)-\mathrm{C}(13)$ & $124.2(6)$ & $\mathrm{O}(2)-\mathrm{C}(26)-\mathrm{C}(27)$ & $109.8(6)$ \\
\hline $\mathrm{N}(3)-\mathrm{C}(14)-\mathrm{H}(14)$ & 117.9 & $C(20)-C(26)-C(27)$ & $111.5(5)$ \\
\hline $\mathrm{C}(13)-\mathrm{C}(14)-\mathrm{H}(14)$ & 117.9 & $\mathrm{O}(2)-\mathrm{C}(26)-\mathrm{H}(26)$ & 108.0 \\
\hline $\mathrm{N}(3)-\mathrm{C}(15)-\mathrm{C}(16)$ & $123.8(6)$ & $\mathrm{C}(20)-\mathrm{C}(26)-\mathrm{H}(26)$ & 108.0 \\
\hline $\mathrm{N}(3)-\mathrm{C}(15)-\mathrm{H}(15)$ & 118.1 & $\mathrm{C}(27)-\mathrm{C}(26)-\mathrm{H}(26)$ & 108.0 \\
\hline $\mathrm{C}(16)-\mathrm{C}(15)-\mathrm{H}(15)$ & 118.1 & $\mathrm{O}(4)-\mathrm{C}(27)-\mathrm{O}(3)$ & $125.3(6)$ \\
\hline$C(15)-C(16)-C(17)$ & $119.3(6)$ & $\mathrm{O}(4)-\mathrm{C}(27)-\mathrm{C}(26)$ & $119.0(7)$ \\
\hline $\mathrm{C}(15)-\mathrm{C}(16)-\mathrm{H}(16)$ & 120.3 & $\mathrm{O}(3)-\mathrm{C}(27)-\mathrm{C}(26)$ & $115.6(6)$ \\
\hline $\mathrm{C}(17)-\mathrm{C}(16)-\mathrm{H}(16)$ & 120.3 & $\mathrm{C}(10)-\mathrm{N}(1)-\mathrm{C}(9)$ & $109.9(5)$ \\
\hline$C(13)-C(17)-C(16)$ & $117.8(6)$ & $\mathrm{C}(10)-\mathrm{N}(1)-\mathrm{H}(1 \mathrm{~A})$ & 125.1 \\
\hline $\mathrm{C}(13)-\mathrm{C}(17)-\mathrm{C}(18)$ & $122.2(5)$ & $\mathrm{C}(9)-\mathrm{N}(1)-\mathrm{H}(1 \mathrm{~A})$ & 125.1 \\
\hline $\mathrm{C}(16)-\mathrm{C}(17)-\mathrm{C}(18)$ & $120.0(6)$ & $\mathrm{C}(10)-\mathrm{N}(2)-\mathrm{C}(8)$ & $109.5(5)$ \\
\hline $\mathrm{C}(17)-\mathrm{C}(18)-\mathrm{C}(19)$ & $112.3(5)$ & $\mathrm{C}(10)-\mathrm{N}(2)-\mathrm{C}(1)$ & $136.8(6)$ \\
\hline $\mathrm{C}(17)-\mathrm{C}(18)-\mathrm{H}(18 \mathrm{~A})$ & 109.1 & $\mathrm{C}(8)-\mathrm{N}(2)-\mathrm{C}(1)$ & $113.7(5)$ \\
\hline $\mathrm{C}(19)-\mathrm{C}(18)-\mathrm{H}(18 \mathrm{~A})$ & 109.1 & $\mathrm{C}(15)-\mathrm{N}(3)-\mathrm{C}(14)$ & $116.8(6)$ \\
\hline $\mathrm{C}(17)-\mathrm{C}(18)-\mathrm{H}(18 \mathrm{~B})$ & 109.1 & $\mathrm{C}(12)-\mathrm{O}(1)-\mathrm{H}(1 \mathrm{~A})$ & 109.5 \\
\hline C(19)-C(18)-H(18B) & 109.1 & $\mathrm{C}(26)-\mathrm{O}(2)-\mathrm{H}(2)$ & 109.5 \\
\hline
\end{tabular}

Symmetry transformations used to generate equivalent atoms: 
Table 4. Anisotropic displacement parameters ( $\AA 2 \times 103)$ for Compound 20. The anisotropic displacement factor exponent takes the form: $-2 \square 2\left[\mathrm{~h} 2 \mathrm{a}^{*} 2 \mathrm{U} 11+\ldots+2 \mathrm{~h} \mathrm{k} \mathrm{a} * \mathrm{~b}^{*} \mathrm{U} 12\right.$ ]

\begin{tabular}{|c|c|c|c|c|c|c|}
\hline & U11 & U22 & U33 & U23 & U13 & U12 \\
\hline $\mathrm{C}(1)$ & $16(3)$ & $19(5)$ & 21(3) & $0(3)$ & $1(3)$ & $2(4)$ \\
\hline$C(2)$ & $21(4)$ & $29(5)$ & $17(4)$ & $-5(3)$ & $-3(3)$ & $-2(4)$ \\
\hline$C(3)$ & $22(4)$ & $34(6)$ & $20(4)$ & $-4(4)$ & $0(3)$ & $-5(4)$ \\
\hline$C(4)$ & $14(3)$ & $41(6)$ & $23(4)$ & $-5(4)$ & $-7(3)$ & $5(4)$ \\
\hline$C(5)$ & $29(4)$ & $29(6)$ & $20(4)$ & $-8(3)$ & $-2(3)$ & $4(4)$ \\
\hline$C(6)$ & $21(4)$ & $33(5)$ & $17(4)$ & $-9(4)$ & $2(3)$ & $2(4)$ \\
\hline$C(7)$ & $19(4)$ & $27(5)$ & $16(4)$ & $-2(4)$ & $-1(3)$ & $5(4)$ \\
\hline$C(8)$ & $30(5)$ & $32(5)$ & $9(4)$ & $-1(4)$ & $-4(3)$ & $2(4)$ \\
\hline $\mathrm{C}(9)$ & $19(4)$ & $45(6)$ & $18(4)$ & $-1(4)$ & $4(3)$ & $3(4)$ \\
\hline$C(10)$ & $24(4)$ & $28(5)$ & $16(4)$ & $-4(4)$ & $-1(3)$ & $-5(4)$ \\
\hline $\mathrm{C}(11)$ & $17(3)$ & $25(5)$ & $20(4)$ & $3(4)$ & $3(3)$ & $-1(4)$ \\
\hline$C(12)$ & $18(4)$ & $31(6)$ & $22(4)$ & $-3(4)$ & $2(3)$ & $-10(4)$ \\
\hline$C(13)$ & $16(4)$ & $20(5)$ & $21(4)$ & $-1(4)$ & $1(3)$ & $4(4)$ \\
\hline$C(14)$ & $19(4)$ & $23(5)$ & $25(4)$ & $2(4)$ & $0(3)$ & $0(4)$ \\
\hline$C(15)$ & $20(4)$ & $38(6)$ & $18(4)$ & $-2(4)$ & $1(3)$ & $7(4)$ \\
\hline$C(16)$ & $21(4)$ & $33(5)$ & $22(4)$ & $6(4)$ & $2(3)$ & $4(4)$ \\
\hline$C(17)$ & $12(3)$ & $26(5)$ & $22(4)$ & $-1(4)$ & $0(3)$ & $7(4)$ \\
\hline$C(18)$ & $19(4)$ & $20(5)$ & $27(4)$ & $2(3)$ & $7(3)$ & $-1(3)$ \\
\hline C(19) & $26(4)$ & $25(5)$ & $22(4)$ & $-8(4)$ & $3(3)$ & $-1(4)$ \\
\hline$C(20)$ & $18(4)$ & $29(5)$ & $21(4)$ & $-4(4)$ & $1(3)$ & $3(4)$ \\
\hline $\mathrm{C}(21)$ & $28(4)$ & $30(5)$ & $26(4)$ & $2(4)$ & $11(3)$ & $6(4)$ \\
\hline $\mathrm{C}(22)$ & $22(4)$ & $39(6)$ & $28(4)$ & $-1(4)$ & $7(3)$ & $-6(4)$ \\
\hline $\mathrm{C}(23)$ & $21(4)$ & $35(6)$ & $23(4)$ & $-3(4)$ & $1(3)$ & $-2(4)$ \\
\hline $\mathrm{C}(24)$ & $36(4)$ & $34(6)$ & $23(4)$ & $3(4)$ & $4(3)$ & $-1(4)$ \\
\hline$C(25)$ & $26(4)$ & $24(5)$ & $25(4)$ & $-4(4)$ & $-1(3)$ & $-2(4)$ \\
\hline$C(26)$ & $25(4)$ & $32(6)$ & $23(4)$ & $1(3)$ & $9(3)$ & $1(4)$ \\
\hline$C(27)$ & $17(4)$ & $37(6)$ & $23(4)$ & $-15(4)$ & $0(3)$ & $-8(4)$ \\
\hline $\mathrm{N}(1)$ & $16(3)$ & $33(5)$ & $23(3)$ & $0(3)$ & $1(3)$ & $6(3)$ \\
\hline $\mathrm{N}(2)$ & $15(3)$ & $30(4)$ & $17(3)$ & $-5(3)$ & $1(2)$ & $4(3)$ \\
\hline $\mathrm{N}(3)$ & $19(3)$ & $35(4)$ & $18(3)$ & $0(3)$ & $-2(2)$ & $2(3)$ \\
\hline $\mathrm{O}(1)$ & $20(2)$ & $34(4)$ & $21(2)$ & $6(2)$ & $0(2)$ & $-6(2)$ \\
\hline $\mathrm{O}(2)$ & $32(3)$ & $46(4)$ & $27(3)$ & $9(3)$ & $6(2)$ & $12(3)$ \\
\hline $\mathrm{O}(3)$ & $28(3)$ & $35(4)$ & $30(3)$ & $8(3)$ & $3(2)$ & $6(3)$ \\
\hline $\mathrm{O}(4)$ & $24(3)$ & $50(4)$ & $31(3)$ & $4(3)$ & $8(2)$ & $5(3)$ \\
\hline
\end{tabular}


Table 5. Hydrogen coordinates ( x 104) and isotropic displacement parameters ( $\AA 2$ x 103) for Compound 20.

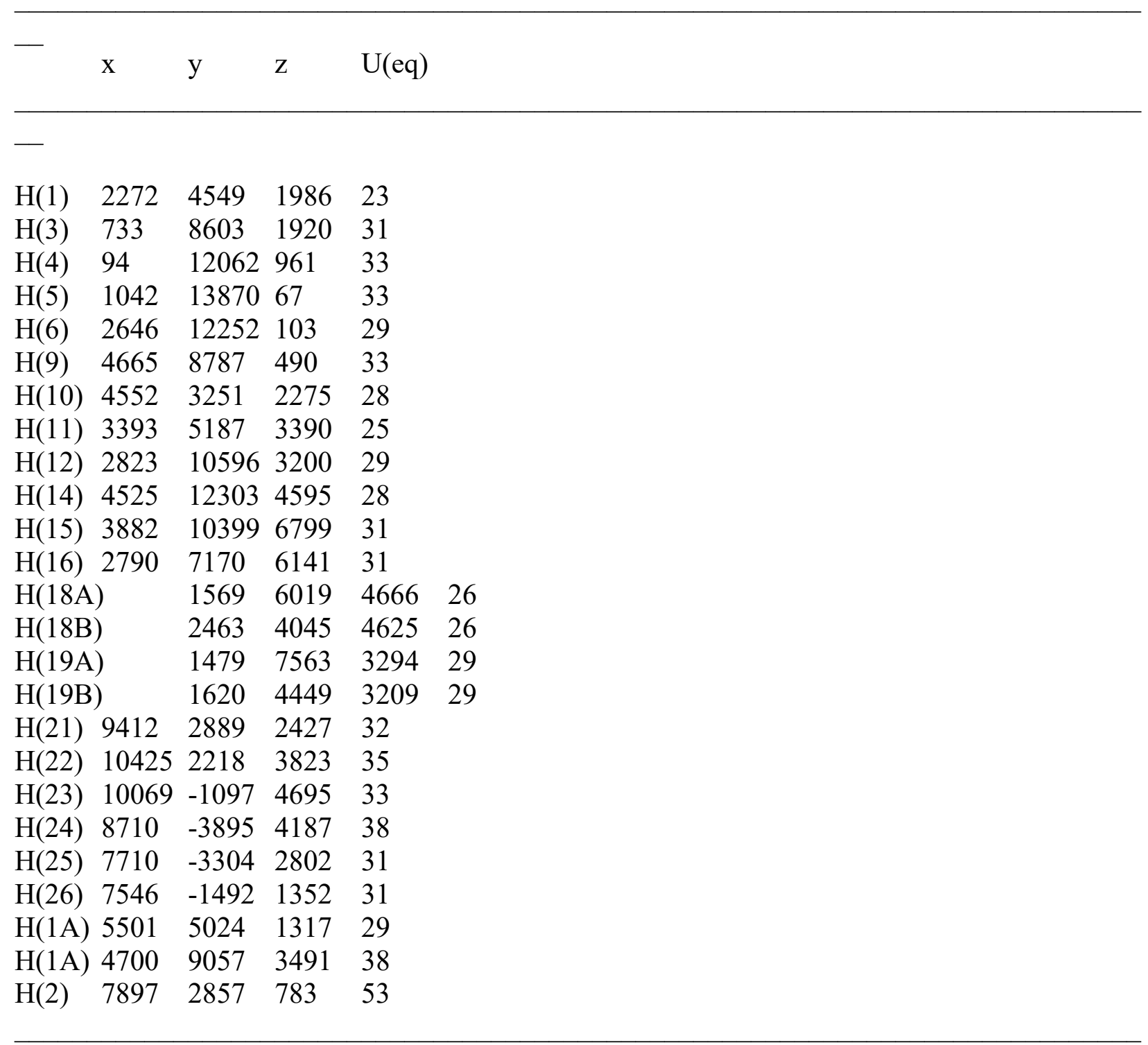




\section{Experimental data for SC-XRD on Compound ent-21}

X-ray quality crystals were grown from a saturated 1,2-dichloroethane/ethanol/methanol solution followed by the slow vapor diffusion of diisopropyl ether to deposit the crystal diffracted. A colorless blade $0.050 \times 0.030 \times 0.020 \mathrm{~mm}$ in size was mounted on a Cryoloop with Paratone oil. Data were collected in a nitrogen gas stream at 100(2) K using and scans. Crystal-to-detector distance was $60 \mathrm{~mm}$ and exposure time was 10 seconds per frame using a scan width of $2.0^{\circ}$. Data collection was $100.0 \%$ complete to $67.000^{\circ}$ in theta. A total of 22900 reflections were collected covering the indices, $-11<=h<=11,-6<=k<=6,-16<=l<=16.2697$ reflections were found to be symmetry independent, with an $\mathrm{R}_{\text {int }}$ of 0.0457 . Indexing and unit cell refinement indicated a primitive, monoclinic lattice. The space group was found to be P 21 (No. 4). The data were integrated using the Bruker SAINT software program and scaled using the SADABS software program. Solution by iterative methods (SHELXT-2014) produced a complete heavyatom phasing model consistent with the proposed structure. All non-hydrogen atoms were refined anisotropically by full-matrix least-squares (SHELXL-2014). All hydrogen atoms were placed using a riding model. Their positions were constrained relative to their parent atom using the appropriate HFIX command in SHELXL-2014. Absolute stereochemistry was unambiguously determined to be $R$ at all chiral centers. 
Table 1. Crystal data and structure refinement for Compound ent-21.

X-ray ID Compound ent-21

Sample/notebook ID Compound ent-21

Empirical formula C20 H18 N2 O

Formula weight $\quad 302.36$

Temperature $100(2) \mathrm{K}$

Wavelength $1.54178 \AA$

Crystal system Monoclinic

Space group P 21

Unit cell dimensions $\mathrm{a}=9.8446(8) \AA \quad$ alpha $=90^{\circ}$.

$$
\begin{array}{ll}
\mathrm{b}=5.8701(5) \AA & \text { beta }=101.772(6)^{\circ} . \\
\mathrm{c}=13.6268(11) \AA & \text { gamma }=90^{\circ} .
\end{array}
$$

Volume $\quad 770.91(11) \AA 3$

Z 2

Density (calculated) $1.303 \mathrm{Mg} / \mathrm{m} 3$

Absorption coefficient $\quad 0.638 \mathrm{~mm}-1$

$\mathrm{F}(000) 320$

Crystal size $\quad 0.050 \times 0.030 \times 0.020 \mathrm{~mm} 3$

Theta range for data collection $\quad 3.313$ to $68.234^{\circ}$.

Index ranges $-11<=\mathrm{h}<=11,-6<=\mathrm{k}<=6,-16<=1<=16$

Reflections collected 22900

Independent reflections 2697 [R(int) $=0.0457]$

Completeness to theta $=67.000^{\circ} \quad 100.0 \%$

Absorption correction Semi-empirical from equivalents

Max. and min. transmission 0.929 and 0.797

Refinement method Full-matrix least-squares on F2

Data / restraints / parameters 2697 / 1 / 209

Goodness-of-fit on F2 1.050

Final $\mathrm{R}$ indices $[\mathrm{I}>2 \operatorname{sigma}(\mathrm{I})] \mathrm{R} 1=0.0313, \mathrm{wR} 2=0.0656$

$\mathrm{R}$ indices (all data) $\mathrm{R} 1=0.0373, \mathrm{wR} 2=0.0690$

Absolute structure parameter 0.03(16)

Extinction coefficient $\mathrm{n} / \mathrm{a}$

Largest diff. peak and hole $\quad 0.150$ and -0.110 e. $\AA-3$ 
Table 2. Atomic coordinates ( $\mathrm{x} 104)$ and equivalent isotropic displacement parameters ( $\AA 2 \mathrm{x}$ 103)

for Compound ent-21. U(eq) is defined as one third of the trace of the orthogonalized Uij tensor.

\begin{tabular}{|c|c|c|c|c|}
\hline- & $\mathrm{X}$ & $\mathrm{U}(\mathrm{eq})$ & & \\
\hline$\overline{\mathrm{C}}(1)$ & $7356(2)$ & $-72(4) \quad 3246(2$ & $28(1)$ & \\
\hline $\mathrm{C}(2)$ & $8695(2)$ & $-1194(5)$ & $3105(2)$ & $28(1)$ \\
\hline$C(3)$ & $9499(2)$ & $-694(5) 2406(2$ & ) $33(1)$ & \\
\hline$C(4)$ & $10627(2)$ & $-2083(5)$ & $2359(2)$ & $37(1)$ \\
\hline$C(5)$ & $10950(3)$ & $-3927(5)$ & 2994(2) & $39(1)$ \\
\hline$C(6)$ & $10155(2)$ & $-4441(5)$ & $3702(2)$ & $36(1)$ \\
\hline$C(7)$ & $9033(2)$ & $-3058(5)$ & $3755(2)$ & $29(1)$ \\
\hline $\mathrm{C}(8)$ & $8034(2)$ & $-3113(5)$ & $4409(2)$ & $28(1)$ \\
\hline $\mathrm{C}(9)$ & $7684(2)$ & $-4058(5)$ & $5244(2)$ & $33(1)$ \\
\hline$C(10)$ & $6286(2)$ & $-1220(5)$ & $4799(2)$ & $31(1)$ \\
\hline $\mathrm{C}(11)$ & $6169(2)$ & $-441(4) 2330(2$ & $26(1)$ & \\
\hline$C(12)$ & $4757(2)$ & $361(4) 2507(2$ & $27(1)$ & \\
\hline$C(13)$ & $3700(2)$ & $262(4) 1522(2$ & $28(1)$ & \\
\hline$C(14)$ & $2676(2)$ & $1913(5)$ & $1274(2)$ & $34(1)$ \\
\hline$C(15)$ & $1687(2)$ & $1784(5)$ & $393(2) 38(1)$ & \\
\hline$C(16)$ & $1695(2)$ & $-47(5)-244(2)$ & $35(1)$ & \\
\hline$C(17)$ & $2714(2)$ & $-1686(5)$ & $-8(2) \quad 32(1)$ & \\
\hline $\mathrm{C}(18)$ & $3750(2)$ & $-1536(5)$ & $855(2) 27(1)$ & \\
\hline$C(19)$ & $4955(2)$ & $-3172(5)$ & $1002(2)$ & $32(1)$ \\
\hline$C(20)$ & $6004(2)$ & $-2915(5)$ & $1988(2)$ & $30(1)$ \\
\hline $\mathrm{N}(1)$ & $6586(2)$ & $-2858(4)$ & $5481(1)$ & $33(1)$ \\
\hline $\mathrm{N}(2)$ & $7130(2)$ & $-1331(4)$ & 4137(1) & $28(1)$ \\
\hline $\mathrm{O}(1)$ & $4849(2)$ & $2542(3)$ & 2953(1) & $33(1)$ \\
\hline
\end{tabular}


Table 3. Bond lengths $[\AA]$ and angles $\left[^{\circ}\right]$ for Compound ent-21.

\begin{tabular}{|c|c|c|c|c|c|}
\hline $\mathrm{C}(1)-\mathrm{N}(2)$ & \multicolumn{2}{|c|}{$1.477(3)$} & $\mathrm{C}(11)-\mathrm{C}(12)$ & \multicolumn{2}{|c|}{$1.533(3)$} \\
\hline$C(1)-C(2)$ & \multicolumn{2}{|c|}{$1.521(3)$} & $\mathrm{C}(11)-\mathrm{H}(11)$ & \multicolumn{2}{|c|}{1.0000} \\
\hline $\mathrm{C}(1)-\mathrm{C}(11)$ & \multicolumn{2}{|c|}{$1.542(3)$} & $\mathrm{C}(12)-\mathrm{O}(1)$ & \multicolumn{2}{|c|}{$1.412(3)$} \\
\hline $\mathrm{C}(1)-\mathrm{H}(1 \mathrm{~A})$ & \multicolumn{2}{|c|}{1.0000} & $C(12)-C(13)$ & \multicolumn{2}{|c|}{$1.523(3)$} \\
\hline $\mathrm{C}(2)-\mathrm{C}(3)$ & \multicolumn{2}{|c|}{$1.388(3)$} & $\mathrm{C}(12)-\mathrm{H}(12)$ & \multicolumn{2}{|c|}{1.0000} \\
\hline$C(2)-C(7)$ & \multicolumn{2}{|c|}{$1.404(3)$} & $C(13)-C(14)$ & \multicolumn{2}{|c|}{$1.389(3)$} \\
\hline$C(3)-C(4)$ & \multicolumn{2}{|c|}{$1.390(4)$} & $\mathrm{C}(13)-\mathrm{C}(18)$ & \multicolumn{2}{|c|}{$1.400(3)$} \\
\hline $\mathrm{C}(3)-\mathrm{H}(3)$ & \multicolumn{2}{|c|}{0.9500} & $C(14)-C(15)$ & \multicolumn{2}{|c|}{$1.385(3)$} \\
\hline$C(4)-C(5)$ & \multicolumn{2}{|c|}{$1.381(4)$} & $\mathrm{C}(14)-\mathrm{H}(14)$ & \multicolumn{2}{|c|}{0.9500} \\
\hline $\mathrm{C}(4)-\mathrm{H}(4)$ & \multicolumn{2}{|c|}{0.9500} & $C(15)-C(16)$ & \multicolumn{2}{|c|}{$1.383(4)$} \\
\hline$C(5)-C(6)$ & \multicolumn{2}{|c|}{$1.395(3)$} & $\mathrm{C}(15)-\mathrm{H}(15)$ & \multicolumn{2}{|c|}{0.9500} \\
\hline $\mathrm{C}(5)-\mathrm{H}(5)$ & \multicolumn{2}{|c|}{0.9500} & $C(16)-C(17)$ & \multicolumn{2}{|c|}{$1.380(4)$} \\
\hline$C(6)-C(7)$ & \multicolumn{2}{|c|}{$1.384(3)$} & $\mathrm{C}(16)-\mathrm{H}(16)$ & 0.950 & \\
\hline $\mathrm{C}(6)-\mathrm{H}(6)$ & 0.95 & & $\mathrm{C}(17)-\mathrm{C}(18)$ & 1.394( & \\
\hline$C(7)-C(8)$ & 1.45 & & $\mathrm{C}(17)-\mathrm{H}(17)$ & 0.950( & \\
\hline$C(8)-C(9)$ & 1.37 & & $\mathrm{C}(18)-\mathrm{C}(19)$ & 1.508( & \\
\hline $\mathrm{C}(8)-\mathrm{N}(2)$ & 1.37 & & $C(19)-C(20)$ & 1.525( & \\
\hline $\mathrm{C}(9)-\mathrm{N}(1)$ & 1.38 & & $\mathrm{C}(19)-\mathrm{H}(19 \mathrm{~A})$ & & 0.9900 \\
\hline C(9)-H(9) & 0.95 & & $\mathrm{C}(19)-\mathrm{H}(19 \mathrm{~B})$ & 0.990 & \\
\hline $\mathrm{C}(10)-\mathrm{N}(1)$ & 1.32 & & $\mathrm{C}(20)-\mathrm{H}(20 \mathrm{~A})$ & & 0.9900 \\
\hline $\mathrm{C}(10)-\mathrm{N}(2)$ & 1.34 & & $\mathrm{C}(20)-\mathrm{H}(20 \mathrm{~B})$ & 0.990 & \\
\hline $\mathrm{C}(10)-\mathrm{H}(10)$ & 0.95 & & $\mathrm{O}(1)-\mathrm{H}(1)$ & 0.840 & \\
\hline$C(11)-C(20)$ & 1.52 & & & & \\
\hline $\mathrm{N}(2)-\mathrm{C}(1)-\mathrm{C}$ & & $99.62(18)$ & $\mathrm{C}(5)-\mathrm{C}(6)-\mathrm{H}(6)$ & & 120.8 \\
\hline $\mathrm{N}(2)-\mathrm{C}(1)-\mathrm{C}$ & & $112.26(19)$ & $C(6)-C(7)-C(2)$ & & $120.9(2)$ \\
\hline $\mathrm{C}(2)-\mathrm{C}(1)-\mathrm{C}($ & & $111.73(18)$ & $\mathrm{C}(6)-\mathrm{C}(7)-\mathrm{C}(8)$ & & $131.6(2)$ \\
\hline $\mathrm{N}(2)-\mathrm{C}(1)-\mathrm{H}$ & 1A) & 110.9 & $\mathrm{C}(2)-\mathrm{C}(7)-\mathrm{C}(8)$ & & $107.5(2)$ \\
\hline $\mathrm{C}(2)-\mathrm{C}(1)-\mathrm{H}$ & (A) & 110.9 & $\mathrm{C}(9)-\mathrm{C}(8)-\mathrm{N}(2)$ & & $105.9(2)$ \\
\hline $\mathrm{C}(11)-\mathrm{C}(1)-\mathrm{H}$ & $(1 \mathrm{~A})$ & 110.9 & $\mathrm{C}(9)-\mathrm{C}(8)-\mathrm{C}(7)$ & & $146.3(2)$ \\
\hline$C(3)-C(2)-C($ & & $120.2(2)$ & $\mathrm{N}(2)-\mathrm{C}(8)-\mathrm{C}(7)$ & & $107.4(2)$ \\
\hline$C(3)-C(2)-C($ & & $128.7(2)$ & $\mathrm{C}(8)-\mathrm{C}(9)-\mathrm{N}(1)$ & & $109.2(2)$ \\
\hline$C(7)-C(2)-C($ & & $110.96(19)$ & $\mathrm{C}(8)-\mathrm{C}(9)-\mathrm{H}(9)$ & & 125.4 \\
\hline$C(2)-C(3)-C($ & & $118.7(2)$ & $\mathrm{N}(1)-\mathrm{C}(9)-\mathrm{H}(9)$ & & 125.4 \\
\hline $\mathrm{C}(2)-\mathrm{C}(3)-\mathrm{H}($ & & 120.6 & $\mathrm{~N}(1)-\mathrm{C}(10)-\mathrm{N}($ & (2) & $110.7(2)$ \\
\hline $\mathrm{C}(4)-\mathrm{C}(3)-\mathrm{H}$ & & 120.6 & $\mathrm{~N}(1)-\mathrm{C}(10)-\mathrm{H}($ & (10) & 124.6 \\
\hline$C(5)-C(4)-C($ & & $121.0(2)$ & $\mathrm{N}(2)-\mathrm{C}(10)-\mathrm{H}($ & (10) & 124.6 \\
\hline $\mathrm{C}(5)-\mathrm{C}(4)-\mathrm{H}$ & & 119.5 & $C(20)-C(11)-C$ & $(12)$ & $107.32(18)$ \\
\hline $\mathrm{C}(3)-\mathrm{C}(4)-\mathrm{H}$ & & 119.5 & $\mathrm{C}(20)-\mathrm{C}(11)-\mathrm{C}$ & (1) & $113.4(2)$ \\
\hline $\mathrm{C}(4)-\mathrm{C}(5)-\mathrm{C}($ & & $120.9(3)$ & $\mathrm{C}(12)-\mathrm{C}(11)-\mathrm{C}$ & (1) & $113.05(18)$ \\
\hline $\mathrm{C}(4)-\mathrm{C}(5)-\mathrm{H}$ & & 119.6 & $\mathrm{C}(20)-\mathrm{C}(11)-\mathrm{H}$ & $\mathrm{I}(11)$ & 107.6 \\
\hline $\mathrm{C}(6)-\mathrm{C}(5)-\mathrm{H}$ & & 119.6 & $\mathrm{C}(12)-\mathrm{C}(11)-\mathrm{H}$ & $\mathrm{I}(11)$ & 107.6 \\
\hline$C(7)-C(6)-C($ & & $118.4(3)$ & $\mathrm{C}(1)-\mathrm{C}(11)-\mathrm{H}(1$ & $(11)$ & 107.6 \\
\hline $\mathrm{C}(7)-\mathrm{C}(6)-\mathrm{H}$ & & 120.8 & $\mathrm{O}(1)-\mathrm{C}(12)-\mathrm{C}(1$ & (13) & $112.7(2)$ \\
\hline
\end{tabular}




$\begin{array}{llll}\mathrm{O}(1)-\mathrm{C}(12)-\mathrm{C}(11) & 111.46(19) & \mathrm{C}(17)-\mathrm{C}(18)-\mathrm{C}(13) & 118.6(2) \\ \mathrm{C}(13)-\mathrm{C}(12)-\mathrm{C}(11) & 109.14(17) & \mathrm{C}(17)-\mathrm{C}(18)-\mathrm{C}(19) & 119.5(2) \\ \mathrm{O}(1)-\mathrm{C}(12)-\mathrm{H}(12) & 107.8 & \mathrm{C}(13)-\mathrm{C}(18)-\mathrm{C}(19) & 121.7(2) \\ \mathrm{C}(13)-\mathrm{C}(12)-\mathrm{H}(12) & 107.8 & \mathrm{C}(18)-\mathrm{C}(19)-\mathrm{C}(20) & 115.2(2) \\ \mathrm{C}(11)-\mathrm{C}(12)-\mathrm{H}(12) & 107.8 & \mathrm{C}(18)-\mathrm{C}(19)-\mathrm{H}(19 \mathrm{~A}) & 108.5 \\ \mathrm{C}(14)-\mathrm{C}(13)-\mathrm{C}(18) & 119.2(2) & \mathrm{C}(20)-\mathrm{C}(19)-\mathrm{H}(19 \mathrm{~A}) & 108.5 \\ \mathrm{C}(14)-\mathrm{C}(13)-\mathrm{C}(12) & 121.2(2) & \mathrm{C}(18)-\mathrm{C}(19)-\mathrm{H}(19 \mathrm{~B}) & 108.5 \\ \mathrm{C}(18)-\mathrm{C}(13)-\mathrm{C}(12) & 119.5(2) & \mathrm{C}(20)-\mathrm{C}(19)-\mathrm{H}(19 \mathrm{~B}) & 108.5 \\ \mathrm{C}(15)-\mathrm{C}(14)-\mathrm{C}(13) & 121.3(2) & \mathrm{H}(19 \mathrm{~A})-\mathrm{C}(19)-\mathrm{H}(19 \mathrm{~B}) & 107.5 \\ \mathrm{C}(15)-\mathrm{C}(14)-\mathrm{H}(14) & 119.4 & \mathrm{C}(11)-\mathrm{C}(20)-\mathrm{C}(19) & 112.0(2) \\ \mathrm{C}(13)-\mathrm{C}(14)-\mathrm{H}(14) & 119.4 & \mathrm{C}(11)-\mathrm{C}(20)-\mathrm{H}(20 \mathrm{~A}) & 109.2 \\ \mathrm{C}(16)-\mathrm{C}(15)-\mathrm{C}(14) & 119.6(2) & \mathrm{C}(19)-\mathrm{C}(20)-\mathrm{H}(20 \mathrm{~A}) & 109.2 \\ \mathrm{C}(16)-\mathrm{C}(15)-\mathrm{H}(15) & 120.2 & \mathrm{C}(11)-\mathrm{C}(20)-\mathrm{H}(20 \mathrm{~B}) & 109.2 \\ \mathrm{C}(14)-\mathrm{C}(15)-\mathrm{H}(15) & 120.2 & \mathrm{C}(19)-\mathrm{C}(20)-\mathrm{H}(20 \mathrm{~B}) & 109.2 \\ \mathrm{C}(17)-\mathrm{C}(16)-\mathrm{C}(15) & 119.5(2) & \mathrm{H}(20 \mathrm{~A})-\mathrm{C}(20)-\mathrm{H}(20 \mathrm{~B}) \\ \mathrm{C}(17)-\mathrm{C}(16)-\mathrm{H}(16) & 120.2 & \mathrm{C}(10)-\mathrm{N}(1)-\mathrm{C}(9) & 106.13(19) \\ \mathrm{C}(15)-\mathrm{C}(16)-\mathrm{H}(16) & 120.2 & \mathrm{C}(10)-\mathrm{N}(2)-\mathrm{C}(8) & 108.1(2) \\ \mathrm{C}(16)-\mathrm{C}(17)-\mathrm{C}(18) & 121.6(2) & \mathrm{C}(10)-\mathrm{N}(2)-\mathrm{C}(1) & 138.0(2) \\ \mathrm{C}(16)-\mathrm{C}(17)-\mathrm{H}(17) & 119.2 & \mathrm{C}(8)-\mathrm{N}(2)-\mathrm{C}(1) & 113.88(18) \\ \mathrm{C}(18)-\mathrm{C}(17)-\mathrm{H}(17) & 119.2 & \mathrm{C}(12)-\mathrm{O}(1)-\mathrm{H}(1) & 109.5\end{array}$

Symmetry transformations used to generate equivalent atoms: 
Table 4. Anisotropic displacement parameters ( $\AA 2 \times 103)$ for Compound ent-21. The anisotropic displacement factor exponent takes the form: $-2 \square 2\left[\mathrm{~h} 2 \mathrm{a}^{*} 2 \mathrm{U} 11+\ldots+2 \mathrm{~h} \mathrm{k} \mathrm{a} * \mathrm{~b} * \mathrm{U} 12\right.$ ]

\begin{tabular}{lllllll}
\hline \multicolumn{1}{c}{$\mathrm{U} 11$} & $\mathrm{U} 22$ & $\mathrm{U} 33$ & $\mathrm{U} 23$ & $\mathrm{U} 13$ & $\mathrm{U} 12$ \\
\hline $\mathrm{C}(1)$ & $31(1)$ & $31(2)$ & $22(1)$ & $3(1)$ & $6(1)$ & $-2(1)$ \\
$\mathrm{C}(2)$ & $27(1)$ & $35(2)$ & $22(1)$ & $-2(1)$ & $4(1)$ & $-4(1)$ \\
$\mathrm{C}(3)$ & $29(1)$ & $44(2)$ & $25(1)$ & $-1(1)$ & $5(1)$ & $-6(1)$ \\
$\mathrm{C}(4)$ & $29(1)$ & $55(2)$ & $26(1)$ & $-6(1)$ & $7(1)$ & $-7(1)$ \\
$\mathrm{C}(5)$ & $31(1)$ & $53(2)$ & $32(1)$ & $-10(1)$ & $4(1)$ & $6(1)$ \\
$\mathrm{C}(6)$ & $34(1)$ & $45(2)$ & $27(1)$ & $-2(1)$ & $2(1)$ & $5(1)$ \\
$\mathrm{C}(7)$ & $27(1)$ & $36(2)$ & $22(1)$ & $-4(1)$ & $3(1)$ & $-2(1)$ \\
$\mathrm{C}(8)$ & $29(1)$ & $32(1)$ & $23(1)$ & $0(1)$ & $3(1)$ & $-1(1)$ \\
$\mathrm{C}(9)$ & $34(1)$ & $38(2)$ & $26(1)$ & $3(1)$ & $3(1)$ & $-1(1)$ \\
$\mathrm{C}(10)$ & $30(1)$ & $39(2)$ & $24(1)$ & $1(1)$ & $7(1)$ & $0(1)$ \\
$\mathrm{C}(11)$ & $29(1)$ & $31(1)$ & $20(1)$ & $3(1)$ & $7(1)$ & $1(1)$ \\
$\mathrm{C}(12)$ & $31(1)$ & $28(1)$ & $24(1)$ & $1(1)$ & $12(1)$ & $-1(1)$ \\
$\mathrm{C}(13)$ & $27(1)$ & $34(2)$ & $24(1)$ & $4(1)$ & $10(1)$ & $-2(1)$ \\
$\mathrm{C}(14)$ & $32(1)$ & $39(2)$ & $33(1)$ & $0(1)$ & $12(1)$ & $6(1)$ \\
$\mathrm{C}(15)$ & $28(1)$ & $46(2)$ & $40(1)$ & $9(1)$ & $8(1)$ & $10(1)$ \\
$\mathrm{C}(16)$ & $26(1)$ & $53(2)$ & $28(1)$ & $6(1)$ & $6(1)$ & $-2(1)$ \\
$\mathrm{C}(17)$ & $30(1)$ & $41(2)$ & $25(1)$ & $0(1)$ & $8(1)$ & $-5(1)$ \\
$\mathrm{C}(18)$ & $26(1)$ & $34(1)$ & $23(1)$ & $3(1)$ & $8(1)$ & $-2(1)$ \\
$\mathrm{C}(19)$ & $32(1)$ & $35(2)$ & $29(1)$ & $-4(1)$ & $6(1)$ & $0(1)$ \\
$\mathrm{C}(20)$ & $30(1)$ & $33(2)$ & $27(1)$ & $0(1)$ & $5(1)$ & $2(1)$ \\
$\mathrm{N}(1)$ & $32(1)$ & $43(1)$ & $24(1)$ & $5(1)$ & $7(1)$ & $-2(1)$ \\
$\mathrm{N}(2)$ & $29(1)$ & $36(1)$ & $21(1)$ & $3(1)$ & $7(1)$ & $0(1)$ \\
$\mathrm{O}(1)$ & $38(1)$ & $32(1)$ & $30(1)$ & $-5(1)$ & $13(1)$ & $-1(1)$ \\
& & & & & & \\
\hline
\end{tabular}


Table 5. Hydrogen coordinates ( x 104) and isotropic displacement parameters ( $\AA 2$ x 103) for Compound ent-21.

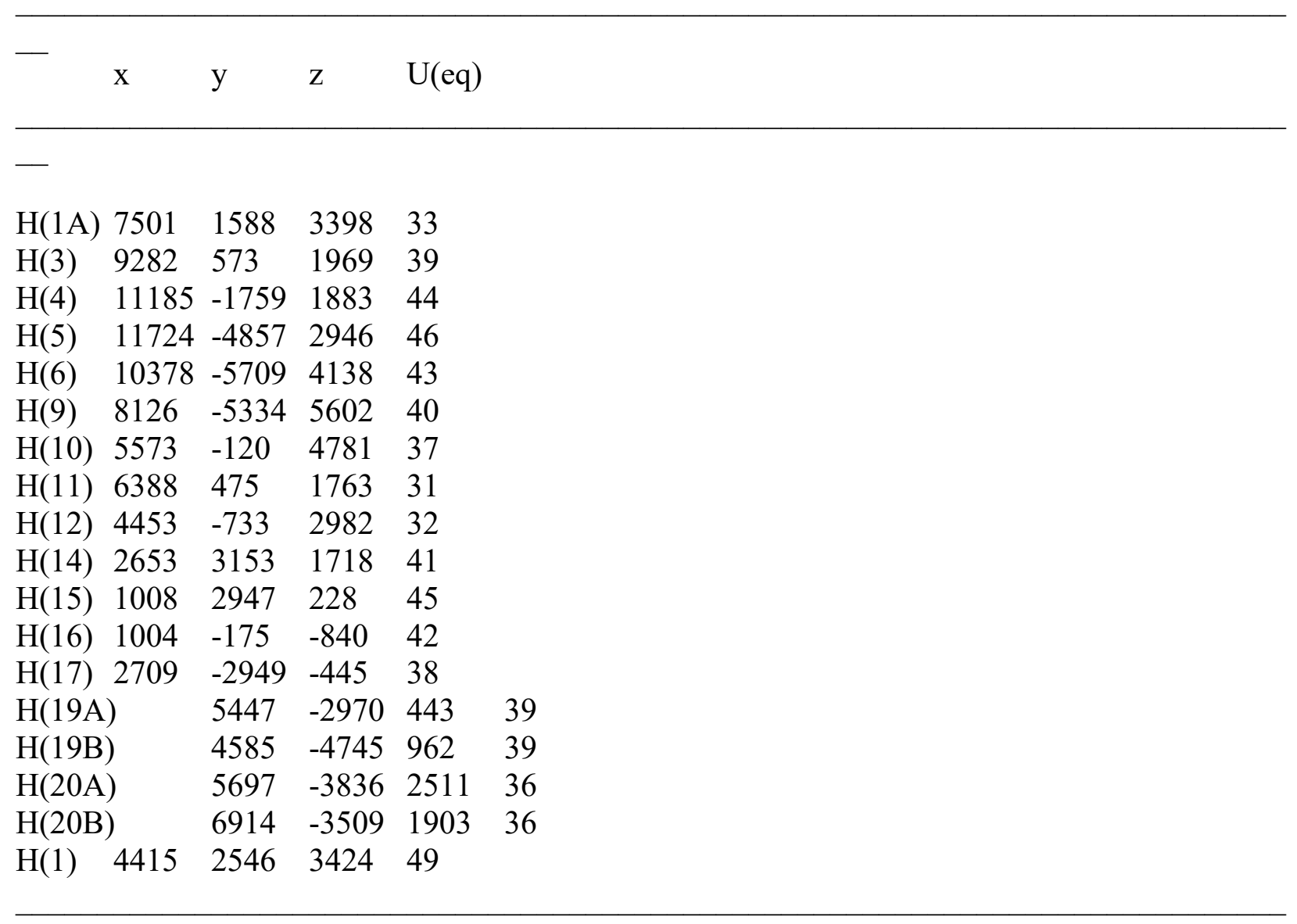




\section{Experimental data for SC-XRD on Compound ent-22}

X-ray quality crystals were grown from a saturated 1,2-dichloroethane/ethanol/methanol solution followed by the slow vapor diffusion of diisopropyl ether to deposit the crystal diffracted. A yellow plate $0.090 \times 0.070 \times 0.050 \mathrm{~mm}$ in size was mounted on a Cryoloop with Paratone oil. Data were collected in a nitrogen gas stream at 100(2) K using and scans. Crystal-to-detector distance was $60 \mathrm{~mm}$ and exposure time was 1 seconds per frame using a scan width of $2.0^{\circ}$. Data collection was $99.6 \%$ complete to $67.000^{\circ}$ in theta. A total of 20046 reflections were collected covering the indices, $-6<=h<=6,-11<=k<=12,-32<=l<=32.2772$ reflections were found to be symmetry independent, with an $\mathrm{R}_{\text {int }}$ of 0.0482 . Indexing and unit cell refinement indicated a primitive, orthorhombic lattice. The space group was found to be P 212121 (No. 19). The data were integrated using the Bruker SAINT software program and scaled using the SADABS software program. Solution by iterative methods (SHELXT-2014) produced a complete heavyatom phasing model consistent with the proposed structure. All non-hydrogen atoms were refined anisotropically by full-matrix least-squares (SHELXL-2014). All hydrogen atoms were placed using a riding model. Their positions were constrained relative to their parent atom using the appropriate HFIX command in SHELXL-2014. Absolute stereochemistry was unambiguously determined to be $R$ at $\mathrm{C} 1, \mathrm{C} 11$, and $\mathrm{C} 12$, respectively. 
Table 1. Crystal data and structure refinement for Compound ent-22.

X-ray ID Compound ent-22

Sample/notebook ID Compound ent-22

Empirical formula

C19 H17 N3 O

Formula weight 303.35

Temperature 100(2) K

Wavelength $1.54178 \AA$

Crystal system

Orthorhombic

Space group P 212121

Unit cell dimensions $\mathrm{a}=5.3519(2) \AA \quad$ alpha $=90^{\circ}$.

$$
\begin{array}{ll}
\mathrm{b}=10.5670(4) \AA & \text { beta }=90^{\circ} . \\
\mathrm{c}=26.7767(11) \AA & \text { gamma }=90^{\circ} .
\end{array}
$$

Volume $\quad$ 1514.32(10) $\AA 3$

Z 4

Density (calculated) $1.331 \mathrm{Mg} / \mathrm{m} 3$

Absorption coefficient $\quad 0.672 \mathrm{~mm}-1$

$\mathrm{F}(000) 640$

Crystal size $\quad 0.090 \times 0.070 \times 0.050 \mathrm{~mm} 3$

Theta range for data collection $\quad 3.301$ to $68.304^{\circ}$.

Index ranges $-6<=\mathrm{h}<=6,-11<=\mathrm{k}<=12,-32<=\mathrm{l}<=32$

Reflections collected 20046

Independent reflections $2772[\mathrm{R}(\mathrm{int})=0.0482]$

Completeness to theta $=67.000^{\circ} \quad 99.6 \%$

Absorption correction Semi-empirical from equivalents

Max. and min. transmission 0.929 and 0.845

Refinement method Full-matrix least-squares on F2

Data / restraints / parameters 2772 / 0 / 209

Goodness-of-fit on F2 1.079

Final $\mathrm{R}$ indices $[\mathrm{I}>2 \operatorname{sigma}(\mathrm{I})] \mathrm{R} 1=0.0408, \mathrm{wR} 2=0.0951$

$\mathrm{R}$ indices (all data) $\quad \mathrm{R} 1=0.0424, \mathrm{wR} 2=0.0961$

Absolute structure parameter -0.09(9)

Extinction coefficient $\mathrm{n} / \mathrm{a}$

Largest diff. peak and hole 0.251 and -0.258 e. $\AA-3$ 
Table 2. Atomic coordinates ( $\mathrm{x} 104)$ and equivalent isotropic displacement parameters ( $\AA 2 \mathrm{x}$ 103)

for Compound ent-22. U(eq) is defined as one third of the trace of the orthogonalized Uij tensor.

\begin{tabular}{lllll}
\hline & \multicolumn{3}{c}{$\mathrm{U}(\mathrm{eq})$} \\
& $\mathrm{x}$ & $\mathrm{z}$ & \\
$\overline{\mathrm{C}}(1)$ & $1682(5)$ & $4753(2)$ & $5888(1)$ & $23(1)$ \\
$\mathrm{C}(2)$ & $2901(5)$ & $3468(2)$ & $5964(1)$ & $25(1)$ \\
$\mathrm{C}(3)$ & $2359(6)$ & $2559(2)$ & $6321(1)$ & $32(1)$ \\
$\mathrm{C}(4)$ & $3843(7)$ & $1479(3)$ & $6340(1)$ & $40(1)$ \\
$\mathrm{C}(5)$ & $5828(6)$ & $1313(3)$ & $6010(1)$ & $41(1)$ \\
$\mathrm{C}(6)$ & $6374(5)$ & $2215(3)$ & $5651(1)$ & $34(1)$ \\
$\mathrm{C}(7)$ & $4891(5)$ & $3291(2)$ & $5629(1)$ & $25(1)$ \\
$\mathrm{C}(8)$ & $4965(5)$ & $4383(2)$ & $5298(1)$ & $24(1)$ \\
$\mathrm{C}(9)$ & $5967(5)$ & $4906(3)$ & $4873(1)$ & $28(1)$ \\
$\mathrm{C}(10)$ & $2959(5)$ & $6137(2)$ & $5109(1)$ & $25(1)$ \\
$\mathrm{C}(11)$ & $1996(5)$ & $5636(2)$ & $6344(1)$ & $23(1)$ \\
$\mathrm{C}(12)$ & $1425(5)$ & $7014(2)$ & $6215(1)$ & $24(1)$ \\
$\mathrm{C}(13)$ & $1388(5)$ & $7778(2)$ & $6697(1)$ & $30(1)$ \\
$\mathrm{C}(14)$ & $-237(10)$ & $8752(3)$ & $6773(1)$ & $74(2)$ \\
$\mathrm{C}(15)$ & $-238(11)$ & $9386(4)$ & $7226(1)$ & $87(2)$ \\
$\mathrm{C}(16)$ & $2810(5)$ & $8150(3)$ & $7526(1)$ & $33(1)$ \\
$\mathrm{C}(17)$ & $3011(5)$ & $7470(3)$ & $7082(1)$ & $29(1)$ \\
$\mathrm{C}(18)$ & $4863(7)$ & $6417(4)$ & $7031(1)$ & $70(1)$ \\
$\mathrm{C}(19)$ & $4615(5)$ & $5587(3)$ & $6575(1)$ & $27(1)$ \\
$\mathrm{N}(1)$ & $4704(4)$ & $6001(2)$ & $4760(1)$ & $28(1)$ \\
$\mathrm{N}(2)$ & $3072(4)$ & $5189(2)$ & $5442(1)$ & $22(1)$ \\
$\mathrm{N}(3)$ & $1238(6)$ & $9092(2)$ & $7608(1)$ & $49(1)$ \\
$\mathrm{O}(1)$ & $-849(3) 7120(2)$ & $5949(1)$ & $29(1)$ \\
& & &
\end{tabular}


Table 3. Bond lengths $[\AA]$ and angles $\left[^{\circ}\right]$ for Compound ent-22.

\begin{tabular}{|c|c|c|c|c|}
\hline $\mathrm{C}(1)-\mathrm{N}(2)$ & $1.481(3)$ & $C(11)-C(12)$ & \multicolumn{2}{|c|}{$1.528(3)$} \\
\hline$C(1)-C(2)$ & $1.520(3)$ & $\mathrm{C}(11)-\mathrm{C}(19)$ & \multicolumn{2}{|c|}{$1.533(3)$} \\
\hline$C(1)-C(11)$ & $1.544(3)$ & $\mathrm{C}(11)-\mathrm{H}(11)$ & \multicolumn{2}{|c|}{1.0000} \\
\hline $\mathrm{C}(1)-\mathrm{H}(1)$ & 1.0000 & $\mathrm{C}(12)-\mathrm{O}(1)$ & \multicolumn{2}{|c|}{$1.415(3)$} \\
\hline$C(2)-C(3)$ & $1.387(4)$ & $C(12)-C(13)$ & \multicolumn{2}{|c|}{$1.521(3)$} \\
\hline$C(2)-C(7)$ & $1.404(4)$ & $\mathrm{C}(12)-\mathrm{H}(12)$ & \multicolumn{2}{|c|}{1.0000} \\
\hline $\mathrm{C}(3)-\mathrm{C}(4)$ & $1.392(4)$ & $C(13)-C(14)$ & \multicolumn{2}{|c|}{$1.363(5)$} \\
\hline $\mathrm{C}(3)-\mathrm{H}(3)$ & 0.9500 & $\mathrm{C}(13)-\mathrm{C}(17)$ & \multicolumn{2}{|c|}{$1.387(4)$} \\
\hline$C(4)-C(5)$ & $1.393(5)$ & $C(14)-C(15)$ & \multicolumn{2}{|c|}{$1.386(4)$} \\
\hline $\mathrm{C}(4)-\mathrm{H}(4)$ & 0.9500 & $\mathrm{C}(14)-\mathrm{H}(14)$ & \multicolumn{2}{|c|}{0.9500} \\
\hline$C(5)-C(6)$ & $1.384(4)$ & $\mathrm{C}(15)-\mathrm{N}(3)$ & \multicolumn{2}{|c|}{$1.329(5)$} \\
\hline $\mathrm{C}(5)-\mathrm{H}(5)$ & 0.9500 & $\mathrm{C}(15)-\mathrm{H}(15)$ & \multicolumn{2}{|c|}{0.9500} \\
\hline$C(6)-C(7)$ & $1.387(4)$ & $\mathrm{C}(16)-\mathrm{N}(3)$ & $1.322(2$ & \\
\hline $\mathrm{C}(6)-\mathrm{H}(6)$ & & $C(16)-C(17)$ & $1.393(3$ & \\
\hline $\mathrm{C}(7)-\mathrm{C}(8)$ & & $\mathrm{C}(16)-\mathrm{H}(16)$ & 0.9500 & \\
\hline $\mathrm{C}(8)-\mathrm{C}(9)$ & & $\mathrm{C}(17)-\mathrm{C}(18)$ & $1.496(<$ & \\
\hline $\mathrm{C}(8)-\mathrm{N}(2)$ & & $\mathrm{C}(18)-\mathrm{C}(19)$ & $1.510(2$ & \\
\hline $\mathrm{C}(9)-\mathrm{N}(1)$ & & $\mathrm{C}(18)-\mathrm{H}(18 \mathrm{~A})$ & & 0.9900 \\
\hline $\mathrm{C}(9)-\mathrm{H}(9)$ & & $\mathrm{C}(18)-\mathrm{H}(18 \mathrm{~B}) 0$ & 0.9900 & \\
\hline $\mathrm{C}(10)-\mathrm{N}(1)$ & & C(19)-H(19A) & & 0.9900 \\
\hline C(10)-N(2) & & $\mathrm{C}(19)-\mathrm{H}(19 \mathrm{~B}) 0$ & 0.9900 & \\
\hline $\mathrm{C}(10)-\mathrm{H}(10) \quad 0$ & & $\mathrm{O}(1)-\mathrm{H}(1 \mathrm{~A}) \quad 0$ & 0.8400 & \\
\hline $\mathrm{N}(2)-\mathrm{C}(1)-\mathrm{C}(2)$ & 99.72(18) & $C(6)-C(7)-C(2)$ & & $121.1(2)$ \\
\hline $\mathrm{N}(2)-\mathrm{C}(1)-\mathrm{C}(11)$ & $113.25(19)$ & $\mathrm{C}(6)-\mathrm{C}(7)-\mathrm{C}(8)$ & & $131.2(2)$ \\
\hline$C(2)-C(1)-C(11)$ & $112.82(19)$ & $C(2)-C(7)-C(8)$ & & $107.7(2)$ \\
\hline $\mathrm{N}(2)-\mathrm{C}(1)-\mathrm{H}(1)$ & 110.2 & $\mathrm{C}(9)-\mathrm{C}(8)-\mathrm{N}(2)$ & & $105.7(2)$ \\
\hline $\mathrm{C}(2)-\mathrm{C}(1)-\mathrm{H}(1)$ & 110.2 & $\mathrm{C}(9)-\mathrm{C}(8)-\mathrm{C}(7)$ & & $146.5(2)$ \\
\hline $\mathrm{C}(11)-\mathrm{C}(1)-\mathrm{H}(1)$ & 110.2 & $\mathrm{~N}(2)-\mathrm{C}(8)-\mathrm{C}(7)$ & & $107.4(2)$ \\
\hline$C(3)-C(2)-C(7)$ & $120.4(2)$ & $\mathrm{C}(8)-\mathrm{C}(9)-\mathrm{N}(1)$ & & $109.2(2)$ \\
\hline $\mathrm{C}(3)-\mathrm{C}(2)-\mathrm{C}(1)$ & $128.3(2)$ & $\mathrm{C}(8)-\mathrm{C}(9)-\mathrm{H}(9)$ & & 125.4 \\
\hline $\mathrm{C}(7)-\mathrm{C}(2)-\mathrm{C}(1)$ & 111.1(2) & $\mathrm{N}(1)-\mathrm{C}(9)-\mathrm{H}(9)$ & & 125.4 \\
\hline$C(2)-C(3)-C(4)$ & 118.2(3) & $\mathrm{N}(1)-\mathrm{C}(10)-\mathrm{N}(2$ & & $110.8(2)$ \\
\hline $\mathrm{C}(2)-\mathrm{C}(3)-\mathrm{H}(3)$ & 120.9 & $\mathrm{~N}(1)-\mathrm{C}(10)-\mathrm{H}(1$ & (10) & 124.6 \\
\hline $\mathrm{C}(4)-\mathrm{C}(3)-\mathrm{H}(3)$ & 120.9 & $\mathrm{~N}(2)-\mathrm{C}(10)-\mathrm{H}(1$ & (10) & 124.6 \\
\hline$C(3)-C(4)-C(5)$ & 121.1(3) & $\mathrm{C}(12)-\mathrm{C}(11)-\mathrm{C}($ & (19) & $107.8(2)$ \\
\hline $\mathrm{C}(3)-\mathrm{C}(4)-\mathrm{H}(4)$ & 119.5 & $\mathrm{C}(12)-\mathrm{C}(11)-\mathrm{C}($ & (1) & $112.10(18)$ \\
\hline $\mathrm{C}(5)-\mathrm{C}(4)-\mathrm{H}(4)$ & 119.5 & $\mathrm{C}(19)-\mathrm{C}(11)-\mathrm{C}($ & C(1) & $113.5(2)$ \\
\hline$C(6)-C(5)-C(4)$ & 120.9(3) & $\mathrm{C}(12)-\mathrm{C}(11)-\mathrm{H}($ & $\mathrm{H}(11)$ & 107.7 \\
\hline $\mathrm{C}(6)-\mathrm{C}(5)-\mathrm{H}(5)$ & 119.5 & $\mathrm{C}(19)-\mathrm{C}(11)-\mathrm{H}($ & $\mathrm{H}(11)$ & 107.7 \\
\hline $\mathrm{C}(4)-\mathrm{C}(5)-\mathrm{H}(5)$ & 119.5 & $\mathrm{C}(1)-\mathrm{C}(11)-\mathrm{H}(1$ & (11) & 107.7 \\
\hline$C(5)-C(6)-C(7)$ & 118.2(3) & $\mathrm{O}(1)-\mathrm{C}(12)-\mathrm{C}(1$ & (13) & $112.0(2)$ \\
\hline $\mathrm{C}(5)-\mathrm{C}(6)-\mathrm{H}(6)$ & 120.9 & $\mathrm{O}(1)-\mathrm{C}(12)-\mathrm{C}(1$ & (11) & $111.2(2)$ \\
\hline $\mathrm{C}(7)-\mathrm{C}(6)-\mathrm{H}(6)$ & 120.9 & $\mathrm{C}(13)-\mathrm{C}(12)-\mathrm{C}($ & (11) & $108.52(18)$ \\
\hline
\end{tabular}




$\begin{array}{llll}\mathrm{O}(1)-\mathrm{C}(12)-\mathrm{H}(12) & 108.4 & \mathrm{C}(17)-\mathrm{C}(18)-\mathrm{C}(19) & 116.6(3) \\ \mathrm{C}(13)-\mathrm{C}(12)-\mathrm{H}(12) & 108.4 & \mathrm{C}(17)-\mathrm{C}(18)-\mathrm{H}(18 \mathrm{~A}) & 108.2 \\ \mathrm{C}(11)-\mathrm{C}(12)-\mathrm{H}(12) & 108.4 & \mathrm{C}(19)-\mathrm{C}(18)-\mathrm{H}(18 \mathrm{~A}) & 108.2 \\ \mathrm{C}(14)-\mathrm{C}(13)-\mathrm{C}(17) & 117.8(2) & \mathrm{C}(17)-\mathrm{C}(18)-\mathrm{H}(18 \mathrm{~B}) & 108.2 \\ \mathrm{C}(14)-\mathrm{C}(13)-\mathrm{C}(12) & 122.3(2) & \mathrm{C}(19)-\mathrm{C}(18)-\mathrm{H}(18 \mathrm{~B}) & 108.2 \\ \mathrm{C}(17)-\mathrm{C}(13)-\mathrm{C}(12) & 119.8(2) & \mathrm{H}(18 \mathrm{~A})-\mathrm{C}(18)-\mathrm{H}(18 \mathrm{~B}) & 107.3 \\ \mathrm{C}(13)-\mathrm{C}(14)-\mathrm{C}(15) & 119.7(3) & \mathrm{C}(18)-\mathrm{C}(19)-\mathrm{C}(11) & 112.8(2) \\ \mathrm{C}(13)-\mathrm{C}(14)-\mathrm{H}(14) & 120.1 & \mathrm{C}(18)-\mathrm{C}(19)-\mathrm{H}(19 \mathrm{~A}) & 109.0 \\ \mathrm{C}(15)-\mathrm{C}(14)-\mathrm{H}(14) & 120.1 & \mathrm{C}(11)-\mathrm{C}(19)-\mathrm{H}(19 \mathrm{~A}) & 109.0 \\ \mathrm{~N}(3)-\mathrm{C}(15)-\mathrm{C}(14) & 124.1(4) & \mathrm{C}(18)-\mathrm{C}(19)-\mathrm{H}(19 \mathrm{~B}) & 109.0 \\ \mathrm{~N}(3)-\mathrm{C}(15)-\mathrm{H}(15) & 118.0 & \mathrm{C}(11)-\mathrm{C}(19)-\mathrm{H}(19 \mathrm{~B}) 109.0 \\ \mathrm{C}(14)-\mathrm{C}(15)-\mathrm{H}(15) & 118.0 & \mathrm{H}(19 \mathrm{~A})-\mathrm{C}(19)-\mathrm{H}(19 \mathrm{~B}) \\ \mathrm{N}(3)-\mathrm{C}(16)-\mathrm{C}(17) & 125.4(3) & \mathrm{C}(10)-\mathrm{N}(1)-\mathrm{C}(9) & 106.4(2) \\ \mathrm{N}(3)-\mathrm{C}(16)-\mathrm{H}(16) & 117.3 & \mathrm{C}(10)-\mathrm{N}(2)-\mathrm{C}(8) & 107.9(2) \\ \mathrm{C}(17)-\mathrm{C}(16)-\mathrm{H}(16) & 117.3 & \mathrm{C}(10)-\mathrm{N}(2)-\mathrm{C}(1) & 138.2(2) \\ \mathrm{C}(13)-\mathrm{C}(17)-\mathrm{C}(16) & 117.7(3) & \mathrm{C}(8)-\mathrm{N}(2)-\mathrm{C}(1) & 113.80(19) \\ \mathrm{C}(13)-\mathrm{C}(17)-\mathrm{C}(18) & 121.5(2) & \mathrm{C}(16)-\mathrm{N}(3)-\mathrm{C}(15) & 115.2(3) \\ \mathrm{C}(16)-\mathrm{C}(17)-\mathrm{C}(18) & 120.8(3) & \mathrm{C}(12)-\mathrm{O}(1)-\mathrm{H}(1 \mathrm{~A}) & 109.5\end{array}$

Symmetry transformations used to generate equivalent atoms: 
Table 4. Anisotropic displacement parameters ( $\AA 2 \mathrm{x} 103)$ for Compound ent-22. The anisotropic displacement factor exponent takes the form: $-2 \square 2\left[\mathrm{~h} 2 \mathrm{a}^{*} 2 \mathrm{U} 11+\ldots+2 \mathrm{~h} \mathrm{k} \mathrm{a} * \mathrm{~b} * \mathrm{U} 12\right.$ ]

\begin{tabular}{|c|c|c|c|c|c|c|}
\hline & U11 & U22 & U33 & U23 & U13 & U12 \\
\hline $\mathrm{C}(1)$ & $23(1)$ & $24(1)$ & $21(1)$ & $2(1)$ & $2(1)$ & $-3(1)$ \\
\hline $\mathrm{C}(2)$ & $29(1)$ & $22(1)$ & $24(1)$ & $0(1)$ & $-5(1)$ & $-5(1)$ \\
\hline $\mathrm{C}(3)$ & $45(2)$ & $25(1)$ & $26(1)$ & $2(1)$ & $-8(1)$ & $-7(1)$ \\
\hline C(4) & $68(2)$ & $23(1)$ & $30(1)$ & $2(1)$ & $-18(1)$ & $-7(1)$ \\
\hline$C(5)$ & $60(2)$ & $23(2)$ & $39(2)$ & $-6(1)$ & $-23(2)$ & $10(1)$ \\
\hline$C(6)$ & $40(2)$ & $28(2)$ & $35(1)$ & $-8(1)$ & $-11(1)$ & $8(1)$ \\
\hline$C(7)$ & $26(1)$ & $23(1)$ & $26(1)$ & $-3(1)$ & $-7(1)$ & $-3(1)$ \\
\hline $\mathrm{C}(8)$ & $22(1)$ & $25(1)$ & $25(1)$ & $-6(1)$ & $-1(1)$ & $0(1)$ \\
\hline$C(9)$ & $26(1)$ & $30(1)$ & $27(1)$ & $-6(1)$ & $5(1)$ & $-2(1)$ \\
\hline$C(10)$ & $30(1)$ & $24(1)$ & 21(1) & 1(1) & 1(1) & $-1(1)$ \\
\hline$C(11)$ & $26(1)$ & $25(1)$ & $18(1)$ & $2(1)$ & $2(1)$ & $-3(1)$ \\
\hline$C(12)$ & $25(1)$ & $26(1)$ & $19(1)$ & $3(1)$ & $2(1)$ & $-2(1)$ \\
\hline$C(13)$ & $45(2)$ & $21(1)$ & $23(1)$ & $4(1)$ & $3(1)$ & $-8(1)$ \\
\hline$C(14)$ & $142(4)$ & $43(2)$ & $37(2)$ & $-11(1)$ & $-30(2)$ & $50(2)$ \\
\hline$C(15)$ & $155(5)$ & $57(2)$ & $50(2)$ & $-24(2)$ & $-34(3)$ & $64(3)$ \\
\hline$C(16)$ & $37(2)$ & $35(2)$ & $27(1)$ & $-4(1)$ & $2(1)$ & $-7(1)$ \\
\hline$C(17)$ & $25(1)$ & $33(1)$ & $29(1)$ & $-5(1)$ & $4(1)$ & $-7(1)$ \\
\hline $\mathrm{C}(18)$ & $39(2)$ & $103(3)$ & $68(2)$ & $-58(2)$ & $-24(2)$ & $28(2)$ \\
\hline$C(19)$ & $30(1)$ & $28(1)$ & $24(1)$ & $0(1)$ & $-2(1)$ & $-1(1)$ \\
\hline $\mathrm{N}(1)$ & $32(1)$ & $26(1)$ & $25(1)$ & $-1(1)$ & $5(1)$ & $-3(1)$ \\
\hline $\mathrm{N}(2)$ & $23(1)$ & $23(1)$ & $20(1)$ & $0(1)$ & 1(1) & $-1(1)$ \\
\hline $\mathrm{N}(3)$ & $74(2)$ & $39(2)$ & $33(1)$ & $-10(1)$ & $-2(1)$ & $13(2)$ \\
\hline $\mathrm{O}(1)$ & $27(1)$ & $31(1)$ & $29(1)$ & $3(1)$ & $-1(1)$ & $2(1)$ \\
\hline
\end{tabular}


Table 5. Hydrogen coordinates ( x 104) and isotropic displacement parameters ( $\AA 2$ x 103) for Compound ent-22.

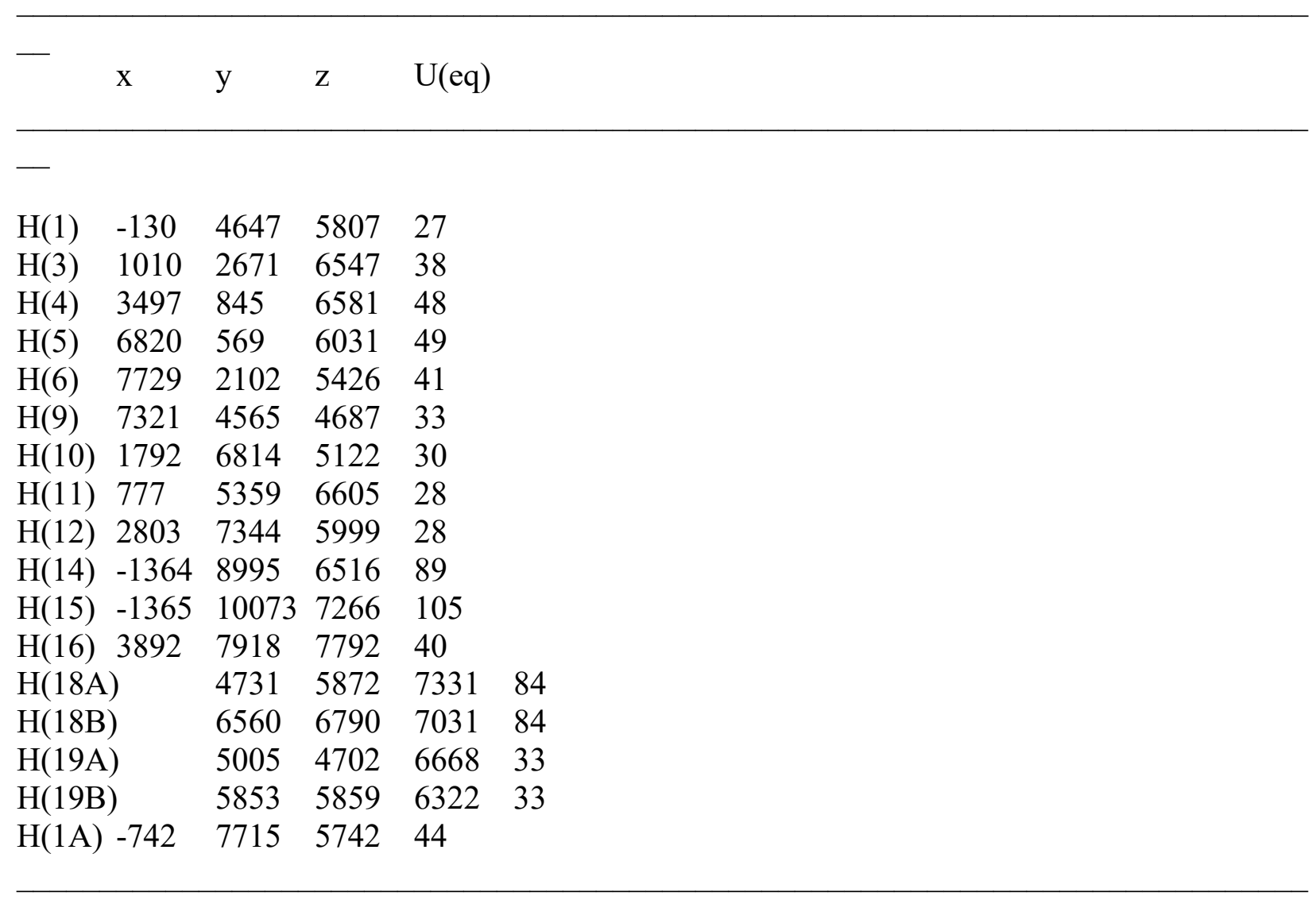




\section{Experimental data for SC-XRD on Compound ent-30}

X-ray quality crystals were grown from a saturated 1,2-dichloroethane/ethanol/methanol solution followed by the slow vapor diffusion of diisopropyl ether to deposit the crystal diffracted. A colorless plate $0.080 \times 0.050 \times 0.020 \mathrm{~mm}$ in size was mounted on a Cryoloop with Paratone oil. Data were collected in a nitrogen gas stream at 100(2) K using and scans. Crystal-to-detector distance was $60 \mathrm{~mm}$ and exposure time was 5 seconds per frame using a scan width of $2.0^{\circ}$. Data collection was $99.5 \%$ complete to $67.000^{\circ}$ in theta. A total of 26837 reflections were collected covering the indices, $-11<=h<=11,-5<=k<=6,-15<=l<=15.2520$ reflections were found to be symmetry independent, with an $\mathrm{R}_{\text {int }}$ of 0.0415 . Indexing and unit cell refinement indicated a primitive, monoclinic lattice. The space group was found to be P 21 (No. 4). The data were integrated using the Bruker SAINT software program and scaled using the SADABS software program. Solution by iterative methods (SHELXT-2014) produced a complete heavy-atom phasing model consistent with the proposed structure. All non-hydrogen atoms were refined anisotropically by full-matrix least-squares (SHELXL-2014). All hydrogen atoms were placed using a riding model. Their positions were constrained relative to their parent atom using the appropriate HFIX command in SHELXL-2014. Absolute stereochemistry was unambiguously determined to be $R$ at all chiral centers. 
Table 1. Crystal data and structure refinement for Compound ent-30.

X-ray ID Compound ent-30

Sample/notebook ID Compound ent-30

Empirical formula $\mathrm{C} 17 \mathrm{H} 16 \mathrm{~N} 4 \mathrm{O}$

Formula weight 292.34

Temperature $100(2) \mathrm{K}$

Wavelength $1.54178 \AA$

Crystal system Monoclinic

Space group P 21

Unit cell dimensions $\mathrm{a}=9.6081(4) \AA \quad$ alpha $=90^{\circ}$.

$$
\begin{array}{ll}
\mathrm{b}=5.9379(2) \AA & \text { beta }=102.380(2)^{\circ} . \\
\mathrm{c}=13.0825(5) \AA & \text { gamma }=90^{\circ} .
\end{array}
$$

Volume $\quad 729.03(5) \AA 3$

Z 2

Density (calculated) $1.332 \mathrm{Mg} / \mathrm{m} 3$

Absorption coefficient $\quad 0.695 \mathrm{~mm}-1$

$\mathrm{F}(000) 308$

Crystal size $\quad 0.080 \times 0.050 \times 0.020 \mathrm{~mm} 3$

Theta range for data collection $\quad 3.459$ to $68.313^{\circ}$.

Index ranges $-11<=\mathrm{h}<=11,-5<=\mathrm{k}<=6,-15<=1<=15$

Reflections collected 26837

Independent reflections 2520 [R(int) $=0.0415]$

Completeness to theta $=67.000^{\circ} \quad 99.5 \%$

Absorption correction Semi-empirical from equivalents

Max. and min. transmission 0.929 and 0.809

Refinement method Full-matrix least-squares on F2

Data / restraints / parameters 2520 / 1 / 200

Goodness-of-fit on F2 1.040

Final $\mathrm{R}$ indices $[\mathrm{I}>2 \operatorname{sigma}(\mathrm{I})] \mathrm{R} 1=0.0261, \mathrm{wR} 2=0.0663$

$\mathrm{R}$ indices (all data) $\mathrm{R} 1=0.0273, \mathrm{wR} 2=0.0674$

Absolute structure parameter 0.15(10)

Extinction coefficient $\mathrm{n} / \mathrm{a}$

Largest diff. peak and hole $\quad 0.136$ and -0.137 e. $\AA-3$ 
Table 2. Atomic coordinates ( $\mathrm{x} 104)$ and equivalent isotropic displacement parameters ( $\AA 2 \mathrm{x}$ 103)

for Compound ent-30. U(eq) is defined as one third of the trace of the orthogonalized Uij tensor.

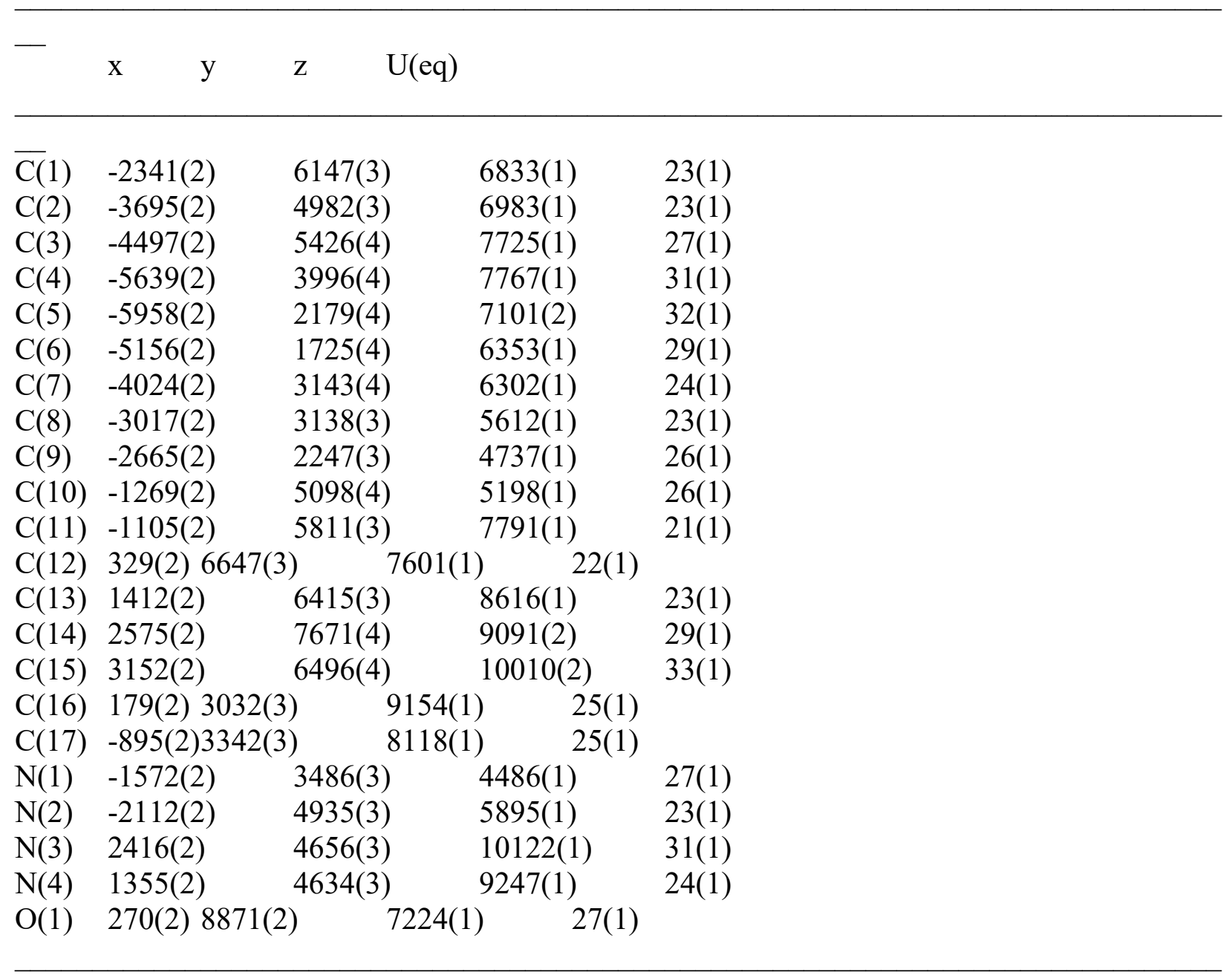


Table 3. Bond lengths $[\AA]$ and angles $\left[^{\circ}\right]$ for Compound ent-30.

\begin{tabular}{|c|c|c|c|c|}
\hline $\mathrm{C}(1)-\mathrm{N}(2)$ & $1.479(2)$ & $\mathrm{C}(10)-\mathrm{H}(10)$ & \multicolumn{2}{|c|}{0.9500} \\
\hline $\mathrm{C}(1)-\mathrm{C}(2)$ & $1.523(2)$ & $\mathrm{C}(11)-\mathrm{C}(17)$ & \multicolumn{2}{|c|}{$1.528(3)$} \\
\hline$C(1)-C(11)$ & $1.544(2)$ & $C(11)-C(12)$ & \multicolumn{2}{|c|}{$1.534(2)$} \\
\hline $\mathrm{C}(1)-\mathrm{H}(1)$ & 1.0000 & $\mathrm{C}(11)-\mathrm{H}(11)$ & \multicolumn{2}{|c|}{1.0000} \\
\hline$C(2)-C(3)$ & $1.388(2)$ & $\mathrm{C}(12)-\mathrm{O}(1)$ & \multicolumn{2}{|c|}{$1.407(2)$} \\
\hline $\mathrm{C}(2)-\mathrm{C}(7)$ & $1.402(3)$ & $\mathrm{C}(12)-\mathrm{C}(13)$ & \multicolumn{2}{|c|}{$1.507(2)$} \\
\hline$C(3)-C(4)$ & $1.398(3)$ & $\mathrm{C}(12)-\mathrm{H}(12)$ & \multicolumn{2}{|c|}{1.0000} \\
\hline $\mathrm{C}(3)-\mathrm{H}(3)$ & 0.9500 & $\mathrm{C}(13)-\mathrm{N}(4)$ & \multicolumn{2}{|c|}{$1.350(3)$} \\
\hline $\mathrm{C}(4)-\mathrm{C}(5)$ & $1.380(3)$ & C(13)-C(14) & \multicolumn{2}{|c|}{$1.376(3)$} \\
\hline $\mathrm{C}(4)-\mathrm{H}(4)$ & 0.9500 & $\mathrm{C}(14)-\mathrm{C}(15)$ & \multicolumn{2}{|c|}{$1.398(3)$} \\
\hline$C(5)-C(6)$ & $1.395(3)$ & C(14)-H(14) & \multicolumn{2}{|c|}{0.9500} \\
\hline $\mathrm{C}(5)-\mathrm{H}(5)$ & 0.9500 & C(15)-N(3) & \multicolumn{2}{|c|}{$1.327(3)$} \\
\hline$C(6)-C(7)$ & $1.387(3)$ & $\mathrm{C}(15)-\mathrm{H}(15)$ & 0.9500 & \\
\hline $\mathrm{C}(6)-\mathrm{H}(6)$ & & $\mathrm{C}(16)-\mathrm{N}(4)$ & 1.461( & \\
\hline $\mathrm{C}(7)-\mathrm{C}(8)$ & & $C(16)-C(17)$ & 1.529 & \\
\hline $\mathrm{C}(8)-\mathrm{C}(9)$ & & $\mathrm{C}(16)-\mathrm{H}(16 \mathrm{~A})$ & & 0.9900 \\
\hline $\mathrm{C}(8)-\mathrm{N}(2)$ & & $\mathrm{C}(16)-\mathrm{H}(16 \mathrm{~B})$ & 0.9900 & \\
\hline $\mathrm{C}(9)-\mathrm{N}(1)$ & & $\mathrm{C}(17)-\mathrm{H}(17 \mathrm{~A})$ & & 0.9900 \\
\hline C(9)-H(9) & & $\mathrm{C}(17)-\mathrm{H}(17 \mathrm{~B})$ & 0.9900 & \\
\hline C(10)-N(1) & & $\mathrm{N}(3)-\mathrm{N}(4)$ & 1.360 & \\
\hline $\mathrm{C}(10)-\mathrm{N}(2)$ & & $\mathrm{O}(1)-\mathrm{H}(1 \mathrm{~A})$ & $0.840 \mathrm{C}$ & \\
\hline $\mathrm{N}(2)-\mathrm{C}(1)-\mathrm{C}(2)$ & $99.75(14)$ & $C(6)-C(7)-C(8)$ & & $131.24(18)$ \\
\hline $\mathrm{N}(2)-\mathrm{C}(1)-\mathrm{C}(11)$ & $112.67(14)$ & $\mathrm{C}(2)-\mathrm{C}(7)-\mathrm{C}(8)$ & & $107.79(16)$ \\
\hline $\mathrm{C}(2)-\mathrm{C}(1)-\mathrm{C}(11)$ & $111.47(14)$ & $\mathrm{C}(9)-\mathrm{C}(8)-\mathrm{N}(2)$ & & $105.65(16)$ \\
\hline $\mathrm{N}(2)-\mathrm{C}(1)-\mathrm{H}(1)$ & 110.8 & $C(9)-C(8)-C(7)$ & & $146.59(19)$ \\
\hline $\mathrm{C}(2)-\mathrm{C}(1)-\mathrm{H}(1)$ & 110.8 & $\mathrm{~N}(2)-\mathrm{C}(8)-\mathrm{C}(7)$ & & $107.28(16)$ \\
\hline $\mathrm{C}(11)-\mathrm{C}(1)-\mathrm{H}(1)$ & 110.8 & $\mathrm{C}(8)-\mathrm{C}(9)-\mathrm{N}(1)$ & & 109.31(17) \\
\hline$C(3)-C(2)-C(7)$ & $120.62(17)$ & $\mathrm{C}(8)-\mathrm{C}(9)-\mathrm{H}(9)$ & & 125.3 \\
\hline$C(3)-C(2)-C(1)$ & $128.42(17)$ & $\mathrm{N}(1)-\mathrm{C}(9)-\mathrm{H}(9$ & & 125.3 \\
\hline $\mathrm{C}(7)-\mathrm{C}(2)-\mathrm{C}(1)$ & $110.76(15)$ & $\mathrm{N}(1)-\mathrm{C}(10)-\mathrm{N}($ & & $110.59(17)$ \\
\hline$C(2)-C(3)-C(4)$ & $118.02(18)$ & $\mathrm{N}(1)-\mathrm{C}(10)-\mathrm{H}($ & (10) & 124.7 \\
\hline $\mathrm{C}(2)-\mathrm{C}(3)-\mathrm{H}(3)$ & 121.0 & $\mathrm{~N}(2)-\mathrm{C}(10)-\mathrm{H}($ & (10) & 124.7 \\
\hline $\mathrm{C}(4)-\mathrm{C}(3)-\mathrm{H}(3)$ & 121.0 & $C(17)-C(11)-C$ & (12) & $106.62(15)$ \\
\hline$C(5)-C(4)-C(3)$ & $121.34(18)$ & $C(17)-C(11)-C$ & (1) & $112.56(15)$ \\
\hline $\mathrm{C}(5)-\mathrm{C}(4)-\mathrm{H}(4)$ & 119.3 & $C(12)-C(11)-C$ & (1) & $112.83(14)$ \\
\hline $\mathrm{C}(3)-\mathrm{C}(4)-\mathrm{H}(4)$ & 119.3 & $\mathrm{C}(17)-\mathrm{C}(11)-\mathrm{H}$ & $\mathrm{I}(11)$ & 108.2 \\
\hline$C(4)-C(5)-C(6)$ & $120.9(2)$ & $\mathrm{C}(12)-\mathrm{C}(11)-\mathrm{H}$ & $\mathrm{I}(11)$ & 108.2 \\
\hline $\mathrm{C}(4)-\mathrm{C}(5)-\mathrm{H}(5)$ & 119.6 & $\mathrm{C}(1)-\mathrm{C}(11)-\mathrm{H}($ & (11) & 108.2 \\
\hline $\mathrm{C}(6)-\mathrm{C}(5)-\mathrm{H}(5)$ & 119.6 & $\mathrm{O}(1)-\mathrm{C}(12)-\mathrm{C}($ & (13) & $111.29(15)$ \\
\hline$C(7)-C(6)-C(5)$ & $118.2(2)$ & $\mathrm{O}(1)-\mathrm{C}(12)-\mathrm{C}($ & (11) & $113.02(15)$ \\
\hline $\mathrm{C}(7)-\mathrm{C}(6)-\mathrm{H}(6)$ & 120.9 & $C(13)-C(12)-C$ & (11) & $107.62(13)$ \\
\hline $\mathrm{C}(5)-\mathrm{C}(6)-\mathrm{H}(6)$ & 120.9 & $\mathrm{O}(1)-\mathrm{C}(12)-\mathrm{H}($ & (12) & 108.3 \\
\hline$C(6)-C(7)-C(2)$ & $120.96(17)$ & $\mathrm{C}(13)-\mathrm{C}(12)-\mathrm{H}$ & $\mathrm{I}(12)$ & 108.3 \\
\hline
\end{tabular}




$\begin{array}{ll}\mathrm{C}(11)-\mathrm{C}(12)-\mathrm{H}(12) & 108.3 \\ \mathrm{~N}(4)-\mathrm{C}(13)-\mathrm{C}(14) & 106.53(16) \\ \mathrm{N}(4)-\mathrm{C}(13)-\mathrm{C}(12) & 119.92(16) \\ \mathrm{C}(14)-\mathrm{C}(13)-\mathrm{C}(12) & 133.53(18) \\ \mathrm{C}(13)-\mathrm{C}(14)-\mathrm{C}(15) & 104.59(19) \\ \mathrm{C}(13)-\mathrm{C}(14)-\mathrm{H}(14) & 127.7 \\ \mathrm{C}(15)-\mathrm{C}(14)-\mathrm{H}(14) & 127.7 \\ \mathrm{~N}(3)-\mathrm{C}(15)-\mathrm{C}(14) & 112.52(18) \\ \mathrm{N}(3)-\mathrm{C}(15)-\mathrm{H}(15) & 123.7 \\ \mathrm{C}(14)-\mathrm{C}(15)-\mathrm{H}(15) & 123.7 \\ \mathrm{~N}(4)-\mathrm{C}(16)-\mathrm{C}(17) & 110.97(15) \\ \mathrm{N}(4)-\mathrm{C}(16)-\mathrm{H}(16 \mathrm{~A}) & 109.4 \\ \mathrm{C}(17)-\mathrm{C}(16)-\mathrm{H}(16 \mathrm{~A}) & 109.4 \\ \mathrm{~N}(4)-\mathrm{C}(16)-\mathrm{H}(16 \mathrm{~B}) & 109.4 \\ \mathrm{C}(17)-\mathrm{C}(16)-\mathrm{H}(16 \mathrm{~B}) & 109.4 \\ \mathrm{H}(16 \mathrm{~A})-\mathrm{C}(16)-\mathrm{H}(16 \mathrm{~B}) \\ \mathrm{C}(11)-\mathrm{C}(17)-\mathrm{C}(16) & 112.78(16) \\ \mathrm{C}(11)-\mathrm{C}(17)-\mathrm{H}(17 \mathrm{~A}) & 109.0 \\ \mathrm{C}(16)-\mathrm{C}(17)-\mathrm{H}(17 \mathrm{~A}) & 109.0 \\ \mathrm{C}(11)-\mathrm{C}(17)-\mathrm{H}(17 \mathrm{~B}) & 109.0 \\ \mathrm{C}(16)-\mathrm{C}(17)-\mathrm{H}(17 \mathrm{~B}) & 109.0 \\ \mathrm{H}(17 \mathrm{~A})-\mathrm{C}(17)-\mathrm{H}(17 \mathrm{~B}) \\ \mathrm{C}(10)-\mathrm{N}(1)-\mathrm{C}(9) & 106.35(15) \\ \mathrm{C}(10)-\mathrm{N}(2)-\mathrm{C}(8) & 108.08(15) \\ \mathrm{C}(10)-\mathrm{N}(2)-\mathrm{C}(1) & 138.16(17) \\ \mathrm{C}(8)-\mathrm{N}(2)-\mathrm{C}(1) & 113.74(14) \\ \mathrm{C}(15)-\mathrm{N}(3)-\mathrm{N}(4) & 103.69(16) \\ \mathrm{C}(13)-\mathrm{N}(4)-\mathrm{N}(3) & 112.67(16) \\ \mathrm{C}(13)-\mathrm{N}(4)-\mathrm{C}(16) & 126.26(15) \\ \mathrm{N}(3)-\mathrm{N}(4)-\mathrm{C}(16) & 120.18(15) \\ \mathrm{C}(12)-\mathrm{O}(1)-\mathrm{H}(1 \mathrm{~A}) & 109.5 \\ & \end{array}$


Symmetry transformations used to generate equivalent atoms: 
Table 4. Anisotropic displacement parameters ( $\AA 2 \times 103)$ for Compound ent-30. The anisotropic displacement factor exponent takes the form: $-2 \square 2\left[\mathrm{~h} 2 \mathrm{a}^{*} 2 \mathrm{U} 11+\ldots+2 \mathrm{~h} \mathrm{k} \mathrm{a} * \mathrm{~b} * \mathrm{U} 12\right.$ ]

\begin{tabular}{lllllll}
\hline \multicolumn{1}{c}{$\mathrm{U} 11$} & $\mathrm{U} 22$ & $\mathrm{U} 33$ & $\mathrm{U} 23$ & $\mathrm{U} 13$ & $\mathrm{U} 12$ \\
\hline $\mathrm{C}(1)$ & $28(1)$ & $24(1)$ & $17(1)$ & $-2(1)$ & $5(1)$ & $2(1)$ \\
$\mathrm{C}(2)$ & $24(1)$ & $26(1)$ & $20(1)$ & $2(1)$ & $3(1)$ & $5(1)$ \\
$\mathrm{C}(3)$ & $28(1)$ & $32(1)$ & $21(1)$ & $1(1)$ & $4(1)$ & $7(1)$ \\
$\mathrm{C}(4)$ & $24(1)$ & $44(1)$ & $23(1)$ & $6(1)$ & $6(1)$ & $7(1)$ \\
$\mathrm{C}(5)$ & $26(1)$ & $43(1)$ & $26(1)$ & $7(1)$ & $3(1)$ & $-2(1)$ \\
$\mathrm{C}(6)$ & $29(1)$ & $34(1)$ & $23(1)$ & $-1(1)$ & $2(1)$ & $-3(1)$ \\
$\mathrm{C}(7)$ & $24(1)$ & $29(1)$ & $18(1)$ & $1(1)$ & $1(1)$ & $4(1)$ \\
$\mathrm{C}(8)$ & $24(1)$ & $24(1)$ & $20(1)$ & $-1(1)$ & $1(1)$ & $1(1)$ \\
$\mathrm{C}(9)$ & $28(1)$ & $29(1)$ & $20(1)$ & $-4(1)$ & $3(1)$ & $0(1)$ \\
$\mathrm{C}(10)$ & $26(1)$ & $33(1)$ & $19(1)$ & $-1(1)$ & $6(1)$ & $1(1)$ \\
$\mathrm{C}(11)$ & $28(1)$ & $22(1)$ & $15(1)$ & $-2(1)$ & $5(1)$ & $0(1)$ \\
$\mathrm{C}(12)$ & $28(1)$ & $20(1)$ & $18(1)$ & $-2(1)$ & $8(1)$ & $1(1)$ \\
$\mathrm{C}(13)$ & $27(1)$ & $24(1)$ & $20(1)$ & $-3(1)$ & $10(1)$ & $2(1)$ \\
$\mathrm{C}(14)$ & $30(1)$ & $33(1)$ & $26(1)$ & $-6(1)$ & $9(1)$ & $-5(1)$ \\
$\mathrm{C}(15)$ & $28(1)$ & $43(1)$ & $26(1)$ & $-8(1)$ & $2(1)$ & $-4(1)$ \\
$\mathrm{C}(16)$ & $32(1)$ & $23(1)$ & $21(1)$ & $2(1)$ & $6(1)$ & $-1(1)$ \\
$\mathrm{C}(17)$ & $28(1)$ & $24(1)$ & $21(1)$ & $-2(1)$ & $3(1)$ & $-1(1)$ \\
$\mathrm{N}(1)$ & $28(1)$ & $33(1)$ & $19(1)$ & $-3(1)$ & $5(1)$ & $2(1)$ \\
$\mathrm{N}(2)$ & $26(1)$ & $26(1)$ & $16(1)$ & $-2(1)$ & $5(1)$ & $0(1)$ \\
$\mathrm{N}(3)$ & $30(1)$ & $40(1)$ & $19(1)$ & $-3(1)$ & $0(1)$ & $2(1)$ \\
$\mathrm{N}(4)$ & $26(1)$ & $28(1)$ & $19(1)$ & $0(1)$ & $3(1)$ & $2(1)$ \\
$\mathrm{O}(1)$ & $36(1)$ & $22(1)$ & $26(1)$ & $2(1)$ & $13(1)$ & $0(1)$ \\
& & & & & & \\
\hline
\end{tabular}


Table 5. Hydrogen coordinates ( x 104) and isotropic displacement parameters ( $\AA 2$ x 103) for Compound ent-30.

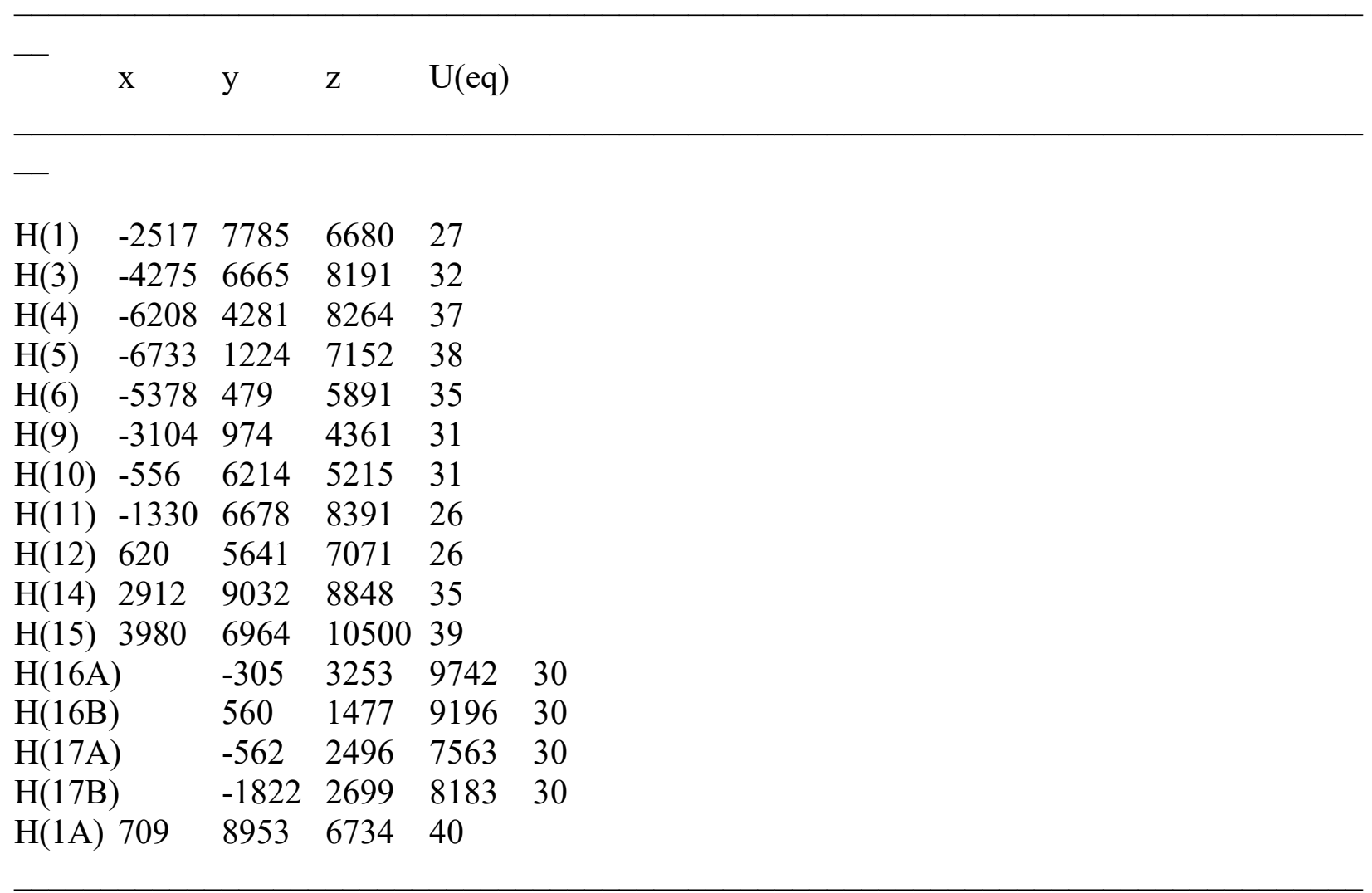




\section{References}

1) Kumar, S.; Waldo, J. P.; Jaipuri, F. A.; Marcinowicz, A.; Van Allen, C.; Adams, J.; Kesharwani, T.; Zhang, X.; Metz, R.; Oh, A. J.; Harris, S. F.; Mautino, M. R. Discovery of clinical candidate $(1 R, 4 r)-4-((R)-2-((S)-6$-fluoro-5H-imidazo[5,1- $a$ ]isoindol-5-yl)-1hydroxyethyl)cyclohexan-1-ol (Navoximod), a potent and selective inhibitor of indoleamine 2,3-dioxygenase 1. J. Med. Chem. 2019, 62, 6705-6733.

2) Mautino, M.; Kumar, S.; Waldo, J.; Jaipuri, F.; Kesharwani, T. Fused imidazole derivatives useful as IDO inhibitors. WO2012142237A1, October 18, 2012.

3) Xingyu, L.; Yuen, P.-w.; Mendonca, R.; Parr, B.; Pastor, R.; Pei, Z.; Gazzard, L.; Jaipuri, F.; Kumar, S.; Li, X.; Pavana, R.; Potturi, H.; Velvadapu, V.; Waldo, J.; Zhang, Z.; Wu, G. TDO2 inhibitors. WO2017107979A1, June 29, 2017.

4) Armer, R.; Bingham, M.; Pesnot, T.; Gignoux, C. 4H-Imidazo[1,5-a]indole derivatives and their use as indoleamine 2,3-dioxygenase (IDO) and/or tryptophan 2,3-dioxygenase (TDO2) modulators. WO2016051181A1, April 7, 2016.

5) Abu-Zied, K. M.; Abu-Bakr, S. M.; Gaafar, A. E.-D. M.; Tokuda, H. Synthesis of novel benzimidazole hydrazine derivatives and its $\mathrm{C}$-nucleosides with antitumor activity. $J$. Appl. Sci. Res. 2013, 9, 852-859.

6) Bochevarov, A. D.; Harder, E.; Hughes, T. F.; Greenwood, J. R.; Braden, D. A.; Philipp, D. M.; Rinaldo, D.; Halls, M. D.; Zhang, J.; Friesner, R. A. Jaguar: A high-performance quantum chemistry software program with strengths in life and materials sciences. Int. J. Quantum Chem. 2013, 113, 2110-2142.

7) Meininger, D.; Zalameda, L.; Liu, Y.; Stepan, L.P.; Borges, L.; McCarter, J. D.; Sutherland, C. L. Purification and kinetic characterization of human indoleamine 2,3dioxygenases 1 and 2 (IDO1 and IDO2) and discovery of selective IDO1 inhibitors. Biochim Biophys Acta. 2011, 1814, 1947-1954.

8) McCoy, A. J.; Grosse-Kunstleve, R. W.; Adams, P. D.; Winn, M. D.; Storoni, L. C.; Read, R. J. Phaser crystallographic software. J. Appl. Cryst. 2007, 40, 658-674.

9) Emsley, P.; Cowtan, K. Coot: model-building tools for molecular graphics. Acta Crystallogr D Biol Crystallogr. 2004, 60, 2126-2132.

10) Bricogne, G.; Blanc, E; Brandl, M.; Flensburg, C.; Keller, P.; Paciorek, W.; Roversi, P.; Sharff, A.; Smart, O. S.; Vonrhein, C.; Womack, T. O. BUSTER version 2.11.4. Global Phasing Ltd. 2011. 